
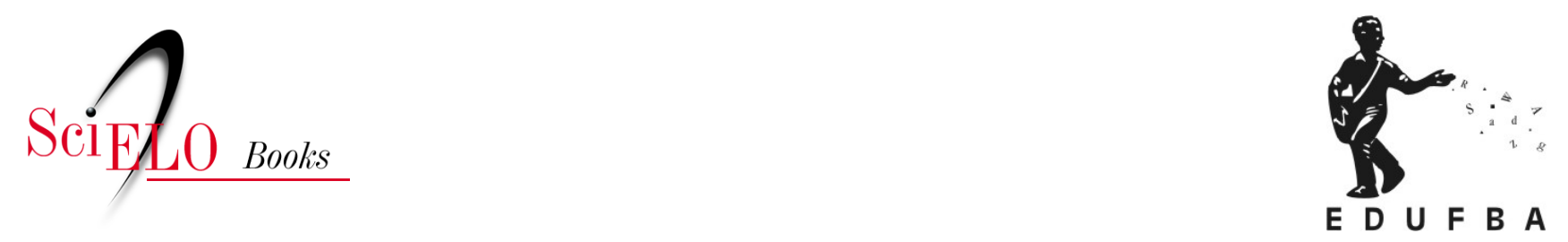

\title{
Subordinação racial no Brasil e na América Latina o papel do Estado, o Direito Costumeiro e a Nova Resposta dos Direitos Civis
}

\author{
Tanya Katerí Hernández \\ Arivaldo Santos de Souza \\ Luciana Carvalho Fonseca \\ (Tradutores)
}

\section{SciELO Books / SciELO Livros / SciELO Libros}

HERNÁNDEZ, T.K. Subordinação racial no Brasil e na América Latina: o papel do Estado, o Direito Costumeiro e a Nova Resposta dos Direitos Civis [online]. Translated by Arivaldo Santos de Souza and Luciana Carvalho Fonseca. Salvador: EDUFBA, 2017, 231 p. ISBN: 978-85-232-2015-0. https://doi.org/10.7476/9788523220150. \section{International license.}

All the contents of this work, except where otherwise noted, is licensed under a Creative Commons Attribution 4.0

Todo o conteúdo deste trabalho, exceto quando houver ressalva, é publicado sob a licença Creative Commons Atribição $\underline{4.0}$. 


\section{Subordinação \\ racial no Brasil e na América Latina}

o papel do Estado, o Direito Costumeiro e a Nova Resposta dos Direitos Civis 
UNIVERSIDADE FEDERAL DA BAHIA

Reitor João Carlos Salles Pires da Silva

Vice-reitor Paulo Cesar Miguez de Oliveira

Assessor do Reitor Paulo Costa Lima

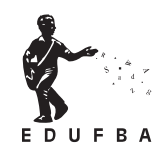

EDITORA DA UNIVERSIDADE FEDERAL DA BAHIA

Diretora Flávia Goulart Mota Garcia Rosa

\section{Conselho Editorial}

Alberto Brum Novaes

Angelo Szaniecki Perret Serpa

Caiuby Alves da Costa

Charbel Niño El Hani

Cleise Furtado Mendes

Dante Eustachio Lucchesi Ramacciotti

Evelina de Carvalho Sá Hoisel

José Teixeira Cavalcante Filho

Maria Vidal de Negreiros Camargo 


\section{Subordinação \\ racial no Brasil e na América Latina}

o papel do Estado, o Direito Costumeiro e a Nova Resposta dos Direitos Civis

\section{TANYA KATERÍ HERNÁNDEZ}

TRADUÇÃo

ARIVALDO SANTOS DE SOUZA

LUCIANA CARVALHO FONSECA 
2017, Autores

Direitos para esta edição cedidos à Edufba.

Feito o Depósito Legal.

Grafia atualizada conforme o Acordo Ortográfico da

Língua Portuguesa de 1990, em vigor no Brasil desde 2009.

Capa e Projeto Gráfico Gabriel Cayres

Revisão e normalização Letícia Rodrigues e Sandra Batista

Sistema de bibliotecas UFBA

Hernández, Tanya Katerí.

Subordinação racial no Brasil e na América Latina: o papel do Estado, o Direito Costumeiro e a Nova Resposta dos Direitos Civis / Tanya Katerí Hernández; tradução Arivaldo Santos de Souza, Luciana Carvalho Fonseca.- Salvador: EDUFBA, 2017.

$231 \mathrm{p}$.

ISBN 978-85-232-1577-4

1. Direito costumeiro. 2. Direitos fundamentais. 3. Negros - Direitos fundamentais - América Latina. 4. Negros - Direitos fundamentais - Brasil. 5. Racismo. 6. Exclusão social. 7. Programas de ação afirmativa Brasil. I. Souza, Arivaldo Santos de. II. Fonseca, Luciana Carvalho. III. Título.

CDD -340.5

Editora afiliada à
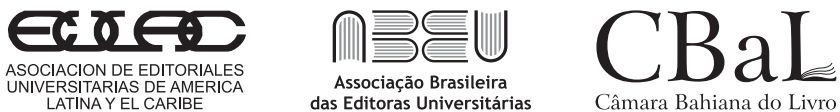

Editora da UFBA

Rua Barão de Jeremoabo

$\mathrm{s} / \mathrm{n}$ - Campus de Ondina

40170-115 - Salvador - Bahia

Tel.: +55 71 3283-6164

Fax: $+55713283-6160$

www.edufba.ufba.br

edufba@ufba.br 


\section{Sumário}

$\begin{array}{ll}\text { Mapas } & 7\end{array}$

$\begin{array}{ll}\text { Prefácio } & 11\end{array}$

A inocência racial e o direito costumeiro de regulação racial 15

América Hispânica branqueia a raça - 31

leis (não) escritas de branqueamento e mestiçagem

A versão brasileira da legislação Jim Crow:

o projeto de embranquecimento do direito de imigração e

o direito costumeiro de segregação racial: um estudo de caso

A exclusão social dos afrodescendentes na América Latina de hoje $\quad 75$

O movimento afrodescendente por justiça social

97

e as novas leis antidiscriminação

Brasil: na vanguarda latino-americana das políticas

de ação afirmativa baseadas em raça e dos recenseamentos

com recorte racial

Conclusão: a conexão entre os Estados Unidos e a América Latina 155

Referências

Apêndice A - Organizações de afrodescendentes

na América Latina

Apêndice B - Tipologia das medidas contra a 
Mapas 
African Slave Trade Routes and Numbers Map

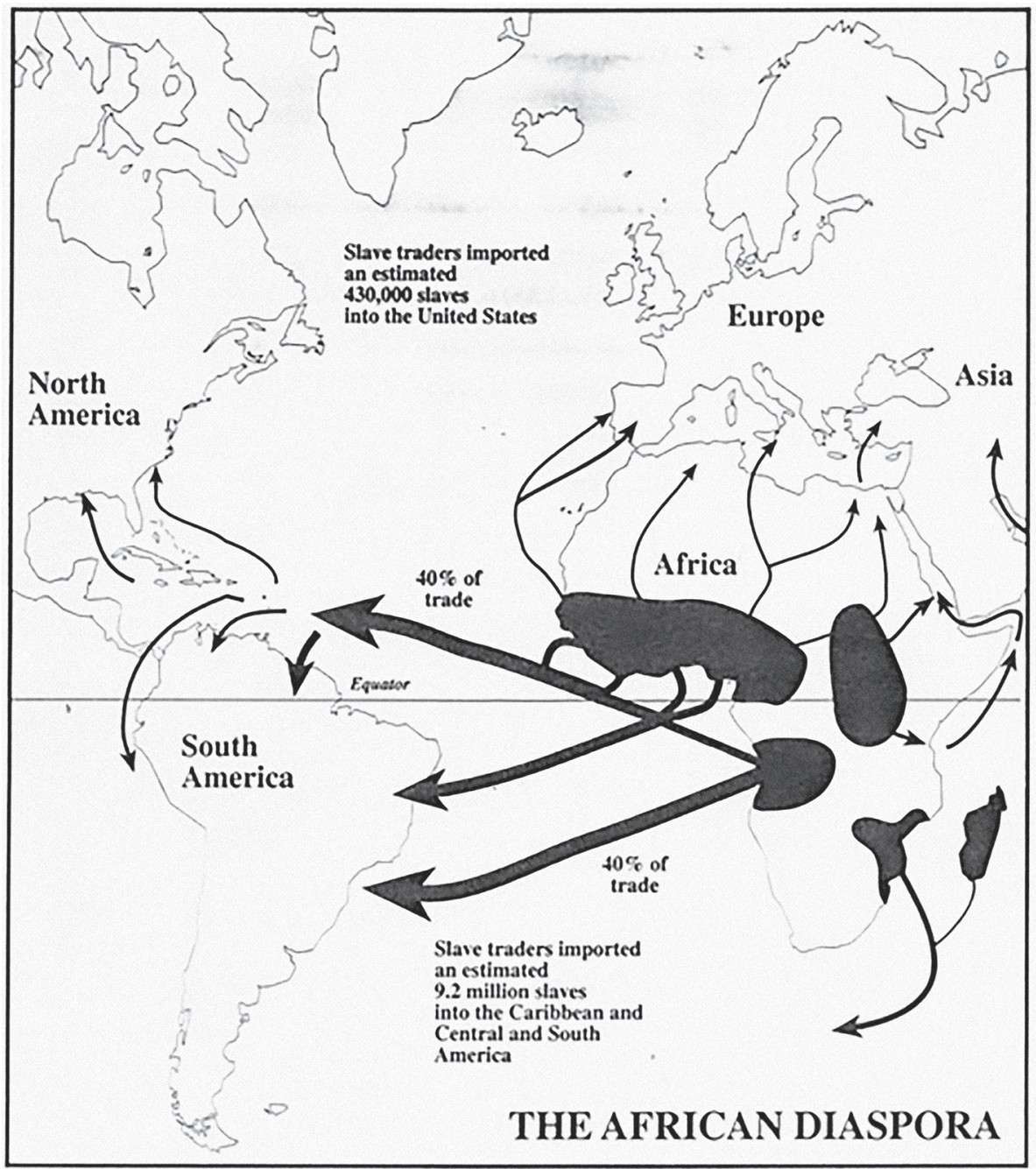

From Williams. Macmillian Encyclopedia of World Slavery, 1E. (c) 1998 Gale, a part of Cengage Learning, Inc. Reproduced by permission. www.cengage.com/permissions 


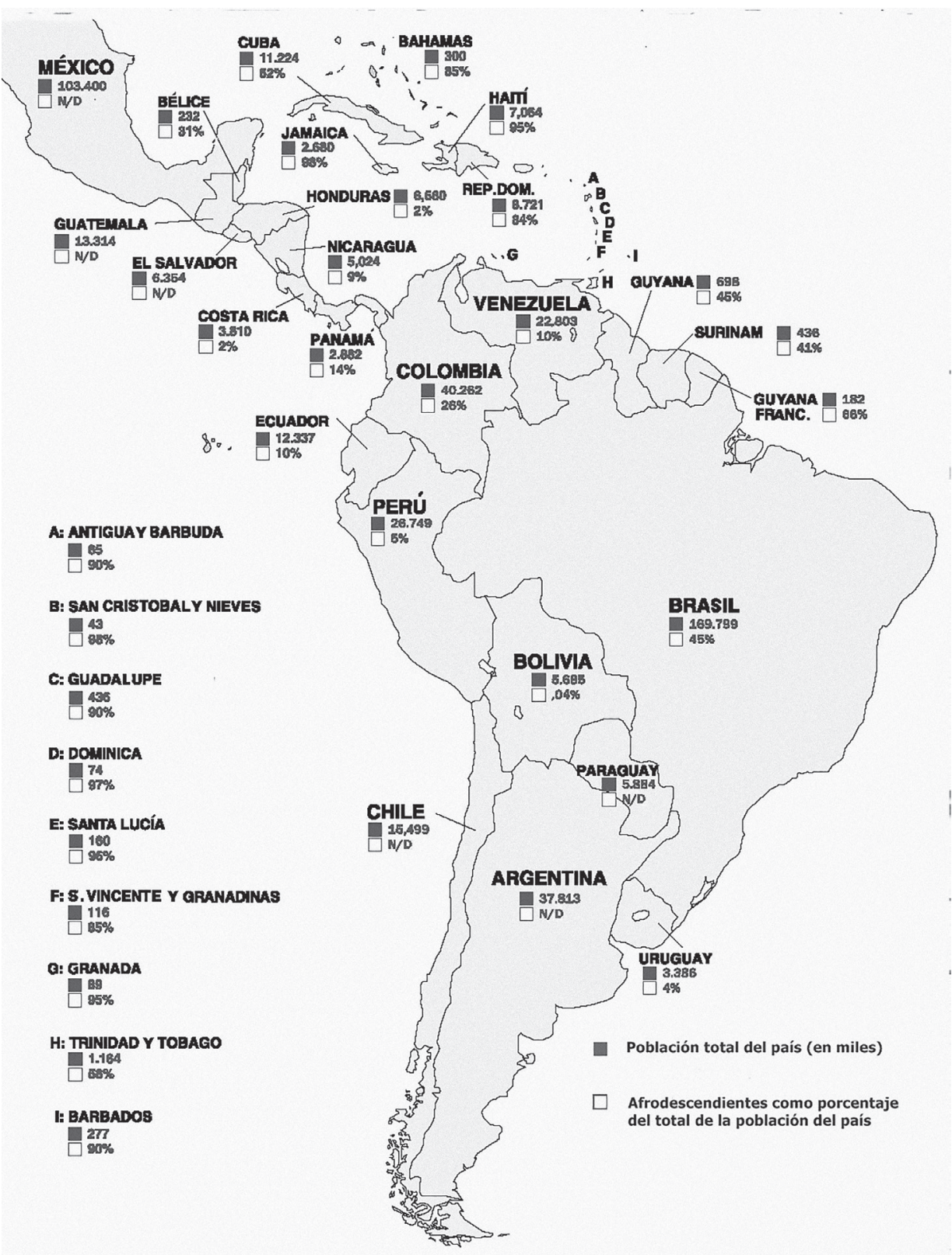




\section{Prefácio}

Subordinação Racial no Brasil e na América Latina é o livro que eu gostaria de ver traduzido para o português e publicado no Brasil. Ao conhecer a autora e a sua obra, percebi que havia encontrado uma peça importante de um quebra-cabeça: o papel do direito na coordenação das relações raciais no hemisfério americano.

A autora desafia a narrativa tradicional do passado legal racialmente benigno da América Latina. Tanya Hernández disseca o direito costumeiro de regulação racial e analisa o desenvolvimento contemporâneo de legislações de igualdade racial na América Latina. Para tanto, examina costumes legais e a histórica cumplicidade dos Estados latino americanos com a criação e manutenção de hierarquias raciais.

Como o leitor verá ao final, a autora empreende o esforço também por interesse próprio, vez que os Estados Unidos continuam a enfrentar graves desafios nessa seara. Não é surpreendente, contudo, que a autora seja filiada a uma universidade estadunidense.

A sociedade daquele país se acostumou a pensar de forma hemisférica, assim a América Latina enquanto objeto de estudo tem lugar na academia daquele 
país. Infelizmente, a academia brasileira (inclusive no que diz respeito ao direito, e ao direito e as relações raciais), dificilmente, recorre aos vizinhos para comparações e aprendizados. Por termos o próprio Estados Unidos e a Europa como objeto preferencial de comparação e inspiração, acabamos por deixar uma lacuna em algumas áreas de estudos.

O livro de Tanya Hernández, a um só tempo, preenche uma lacuna na literatura jurídica, das ciências sociais e das ciências humanas. Ao estudar o direito costumeiro latino americano do período pós-escravidão, a autora dá visibilidade ao legado do período abordado não só para a história dos países latinos, mas também para a vida das pessoas que neles vivem.

A abordagem do livro inaugura um novo capítulo no estudo do direito e das relações raciais. No plano geral, sem perceber, desafia o complexo de vira lata dos brasileiros, vez que coloca o país e algumas de suas políticas públicas como a vanguarda latino americana de promoção da igualdade racial. Outrossim, reinvidica a área de estudos para os juristas, visto que os antropólogos reinam soberanos até o momento.

O livro é original também porque, do ponto de vista metodológico, toma como referência o direito costumeiro e não o direito legislado. Do ponto de vista do conteúdo, oferece motivos para que se amplie a área temática dos estudos da área, em cuja predomina a mesmice modorrenta de estudos sobre ações afirmativas, e diferenciações entre crime de racismo e injúria racista.

Em particular no último caso, a autora diretamente critica a esperança desproporcional que é depositada no direito criminal enquanto resposta jurídica à longa história de marginalização e negação do racismo. Indiretamente, tal abordagem abre espaço para uma crítica mais integral que, embora aceite que parte dos nossos problemas tem a ver com o legado da escravidão, também percebe que parte da responsabilidade das desigualdades raciais na região tem a ver com as diferentes configurações do Estado Desenvolvimentista, inclusive com o Nacional-Consumismo do governo petista.

Estatudo da Igualdade Racial sem orçamento que o viabilize e a redução da participação em espaços de poder a secretarias e ministérios de promoção da igualdade racial, nas palavras da Ministra Luiza Bairros, são meros sinais da minoridade política dos seus artífices.

A obra também apresenta lacunas. Algumas dizem respeito a atualizações legais, outras dizem respeito a omissões importantes. Obras de alguns autores brasileiros que se debruçaram sobre tais temas teriam muito a contribuir com 
o livro. Notadamente: Fernando Henrique Cardoso, Lilia Moritz Schwarcz, Octávio Ianni, Florestan Fernandes e Gilberto Freyre. Tais autores ajudariam a explicar melhor a moldura econômica e institucional na qual as transformações socioculturais ocorreram. Similarmente, dariam uma ideia mais precisa das fraturas nas elites e da cooptação de oprimidos.

Apesar das lacunas, algo particularmente interessante na obra ora prefaciada é que a mesma abre e aponta caminhos para onde podemos seguir, não somente rumos acadêmicos, mas também opções de políticas públicas. O livro abre caminhos para refletir sobre o que realmente importa: o esgotamento da capacidade de obter conquistas por meio da atual institucionalidade brasileira.

Entre as reflexões sobre a tradução realizadas com Luciana Carvalho Fonseca, professora dos cursos de Letras e Tradução da Pontifícia Universidade Católica de São Paulo e da Universidade de São Paulo, a versão brasileira ganhou o nome de Subordinação Racial no Brasil e na América Latina. A intervenção no título original, que - coerentemente com a perspectiva da cultura de partida - é apenas Subordinação Racial na América Latina, vem para deixar claro para os leitores brasileiros que o livro também trata do seu país, aliás com muito destaque; e também para individualizar o Brasil no contexto continental, à luz da nossa ainda mal definida identidade latina.

Agradeço a autora, a cotradutora, a editora, a José Garcez Ghirardi e a todas as pessoas que acreditaram na ideia e colaboraram para o sucesso do projeto. 


\section{A inocência racial e o direito costumeiro de regulação racial}

Não acho que exista muito racismo na América Latina porque somos uma mistura de raças de todos os tipos, europeus, africanos, asiáticos e outras raças que existiram e existirão; mas entendo que exista racismo em muitas outras partes, principalmente nos Estados Unidos e na Europa, lá é onde existe mais racismo. (IBEROAMÉRICA, 2005)

Há cerca de 150 milhões de pessoas de ascendência africana na América Latina, representando cerca de um terço da população total (ver mapas 1 e 2). (SÁNCHEZ; BRYAN, 2003, p. 3-4) Todavia, esses são dados que podem ser considerados conservadores se levarmos em conta o histórico de subcontagem dos afrodescendentes nos censos latino-americanos, os quais frequentemente não apresentam um campo para registrar a origem étnica/racial dos entrevistados. (HOOKER, 2008, p. 279-281) Ao mesmo tempo, os afrodescendentes representam mais de $40 \%$ da população latino-americana pobre e têm sido tradicionalmente marginalizados e inferiorizados por serem considerados elementos indesejáveis pela sociedade desde a abolição da escravidão nos diversos países americanos. (GATES JUNIOR, 2011; MÁRQUEZ et al., 
2007, p. 15-17) Ainda assim, a visão de que "racismo não existe" é bastante difundida na América Latina, a despeito do advento dos movimentos sociais negros e de cientistas sociais demonstrarem o contrário. Quando a BBC entrevistou latino-americanos, em 2005, sobre a existência de racismo na região, um número significativo de pessoas enfaticamente negou sua existência. Muitos, por exemplo, falaram que "ibero-americanos não são racistas" e que "A América Ibérica não é uma região racista pelo simples fato de ser a maioria da população indígena, crioula ou mestiça”. (IBEROAMÉRICA, 2005)

Assim, a negação do racismo está enraizada no que muitos acadêmicos chamam de o "mito da democracia racial" - a noção de que a mestiçagem (mestizaje, em castelhano) em uma população é uma característica emblemática de harmonia racial e impossibilita discórdia e desigualdade racial. As pesquisas acadêmicas nos últimos 20 anos têm criticado as teorias latino-americanas de "mestiçagem”, segundo as quais a mistura seria a marca registrada da harmonia racial. Contudo, os latino-americanos continuam defendendo a noção de que, ao contrário dos Estados Unidos, por haver na região uma grande miscigenação, inexiste respaldo jurídico no estilo da legislação ${ }^{1}$ Jim Crow, tornando a América Latina "racialmente inocente", termo cunhado por mim. De fato, uma ampla pesquisa, Americas Barometer 2010, do Projeto Opinião Pública na América Latina, demonstrou que as ideologias latino-americanas racialmente preconceituosas não evoluíram completamente a despeito da existência de críticas acadêmicas à ideia de mestiçagem como uma alegoria para a inocência racial. Por exemplo, na pesquisa Americas Barometer 2010 na Bolívia, Brasil, Colômbia, República Dominicana, Equador, Guatemala, México e Peru, a grande maioria das populações (de todas as raças), ao ser indagada sobre a noção de mestiçagem, considerava que "a mistura racial é boa para o país". (LATIN AMERICAN PUBLIC OPINION PROJECT OF VANDERBILT UNIVERSITY, 2010b) De fato, mais de $75 \%$ de todos os entrevistados concordaram com a ideia de mestiçagem e expressaram ampla aprovação à prática de casamentos inter-raciais. Contudo, os dados do Americas Barometer também mostraram que o número de latino-americanos que desaprovaram a ideia de seus filhos casarem com parceiros negros foi exponencialmente superior entre os brancos em relação aos

1 Conjunto de normas aprovadas ou intencionalmente interpretadas com o fim de discriminar negros, como as leis que determinavam banheiros separados para brancos e negros. (GARNER, 2005, p. 694) (N.T.) 
negros. Mais especificamente, nos países onde o Americas Barometer perguntou se os entrevistados aprovariam uma união entre um filho e uma pessoa negra, no caso do Brasil, Colômbia, República Dominicana e Equador, a reprovação por parte dos brancos foi, em média, $60 \%$ maior do que a reprovação por parte dos negros (em outros países, os entrevistados foram perguntados sobre casamento com pessoas de ascendência indígena). Assim, tais resultados estão de acordo com as tradicionais estatísticas que apontam os casamentos latino-americanos como, de maneira geral, racialmente endogâmicos. (WADE, 2009, p. 168-173)

Os dados da pesquisa Americas Barometer 2010 também indicam que os entrevistados brancos em vários países latino-americanos são consideravelmente mais propensos que os entrevistados de outros grupos a declararem preferência por pessoas de pele mais clara. Por exemplo, na Colômbia, no Equador e na República Dominicana, em média, 26\% dos entrevistados brancos afirmaram que preferiam pessoas de pele clara. Em contrapartida, em média, 13\% dos entrevistados negros afirmaram preferir pessoas de pele clara. No México e no Peru, negros, em média, tinham maiores taxas de preferência por pessoas de pele clara (37\%) do que brancos (26\%). No Brasil, a taxa de preferência por pessoas de pele mais clara foi bem parecida em ambos os grupos. Mesmo a Cuba socialista segue preferindo a branquitude e a população branca segue rejeitando casamentos inter-raciais. Além do mais, em uma comparação (de 2004) do preconceito racial implícito e explícito nos Estados Unidos, Cuba, República Dominicana e Porto Rico, as taxas de preconceito racial explícito e implícito foram mais altas nos três países latino-americanos em comparação às taxas americanas. (PEÑA; SIDANIUS; SAWYER, 2004, p. 749-762) Desse modo, a despeito da esmagadora articulação da mestiçagem como um indicador de harmonia racial na maior parte da América Latina e os diferentes modos que a articulação se dá em cada país, as atitudes de discriminação racial subjazem à aclamada miscigenação. Em parte, a ausência de uma crítica jurídica envolvendo uma comparação entre as leis norte-americanas Jim Crow e os sistemas jurídicos latino-americanos têm permitido que o discurso de "inocência racial" latino-americana persista. Este livro busca preencher essa lacuna na literatura acadêmica sobre o tema e fornecer uma crítica jurídica.

Especificamente, este livro trata das formas como a negação latino-americana do racismo é operada juntamente com a noção de que o verdadeiro racismo só pode ser encontrado na segregação racial estadunidense, fazendo com que as 
manifestações de racismo na América Latina permaneçam veladas. Meu argumento é que um exame do papel do Estado no período subsequente à abolição da escravidão na regulação das relações raciais por meio de leis de imigração e do direito costumeiro rompe com a imagem de que a América Latina é uma região "racialmente inocente". Em seguida, avalio as formas pelas quais, atualmente, as legislações latino-americanas referentes à igualdade racial estão tentando erradicar o legado de desigualdade racial forjado pelo racismo estatal perpetuado ao longo da história. Por fim, concluirei o livro com insights sobre como o exame do contexto latino-americano pode ser de valia aos movimentos negros estadunidenses de hoje. Ao realizar este trabalho, emprego o termo "afrodescendentes" que acadêmicos e ativistas usam para designar todas as pessoas latino-americanas de ascendência africana que são afetadas pelo sentimento antinegro, quer elas se autoidentifiquem (ou não) como negras, quer adotem uma identidade multirracial, como a de mulato ou mestiço. Este livro não abordará assuntos de desigualdade racial em relação a grupos indígenas latino-americanos, uma vez que já existe uma vasta literatura sobre o assunto. A análise deste livro será focada na história das relações dos afrodescendentes com o Estado, enquanto ex-escravizados reivindicando cidadania e participação integral na identidade nacional a despeito da negação social da existência de racismo.

\section{“Não somos racistas!”. A negação do racismo como máscara da discriminação racial}

A força da negação do racismo na América Latina é tão grande que mesmo sua expressão generalizada e a disseminação do discurso racista são vistos como algo irrelevante. Contudo, o termo "negro" é amplamente considerado depreciativo, uma vez que pessoas de ascendência africana são estereotipadas e consideradas essencialmente criminosas, intelectualmente inferiores, excessivamente sexuais e animalescas. Por serem muito comuns na região, os estereótipos raciais ligados às pessoas de ascendência africana, entende-se que as mesmas cheiram a animais, em particular, a macacos. Além dos estereótipos comuns acerca dos negros na América Latina, cada país da região também desenvolveu seu próprio subconjunto de termos depreciativos para se referir aos negros e à negritude.

Na Argentina, "negro de mierda" ("negro de merda") é uma expressão popular (COURTIS et al., 2009, p. 13, 32), e "negro" é visto como o pior dos insultos. (ARI, 
2010) Como resultado, mesmo as canções infantis argentinas são repletas de referências antinegros, tais como "Eu gosto do branco, vida longa para o branco, morte ao negro”. (PIDEN, 2010) A título de exemplo, um jovem argentino criou uma página no Facebook chamada "Extermínio dos Negros de Merda". (NERI, 2008) No Brasil, os afrodescendentes são chamados de "macaco", "besta", "vagabundo", "filho da puta", "safado", "ladrão" e "nega fedorenta”. (VAN DIJK, 2005, p. 136137) Claramente, os insultos brasileiros estão associados à noção de negritude. Infelizmente, tais figuras são reproduzidas em livros didáticos infantis, nos quais pessoas negras são reiteradamente descritas como animais, socialmente subordinadas e representadas por outras formas estereotipadas. (SILVA JUNIOR, 2002, p. 34-38) Nos jornais colombianos, até mesmo o ar poluído de Cali é atribuído à suposta sujeira dos negros. (SALAZAR, 2008) Na Costa Rica, é comum que os negros sejam descritos como porcos, fedorentos, desalinhados e feios. (JIMÉNEZ CASTRO, 2001, p. 43) Em Cuba, "fazer coisas como um negro" é uma expressão comum para descrever uma atividade mal feita ou atos de delinquência. (RAVSBERG, 2003) A própria Academia de Ciências Cubana estabeleceu, em 2003, que dezenas de frases cubanas têm sido usadas para associar negros à delinquência e à inferioridade. (RAVSBERG, 2003) Isso é melhor exemplificado pelas frases populares como "Tinha que ser um negro" (AVELLANEDA, 2005) e "Não há negro bom, nem tamarindo doce”. (DUHARTE JIMÉNEZ; GARCÍA, 2005) No Equador, uma frase frequentemente repetida é a de que um negro correndo é um ladrão e um branco correndo é um atleta. (ANDALUZ PRADO, 2009) Isso ajuda a explicar os resultados de uma pesquisa feita em 2009, a qual demonstrou que cinco em cada sete equatorianos têm preconceito racial contra negros. (ANDALUZ PRADO, 2009) Até mesmo as autoridades do governo equatoriano se sentem à vontade para expressar suas ideias sobre o assunto. Um chefe de polícia declarou publicamente em 1995 que "existe um tipo racial que apresenta tendência a delinquir, a cometer atos horríveis... que é a raça negra, a qual está tomando conta dos centros urbanos do país, formando cinturões de pobreza que conduzirão à delinquência por causa da ignorância e insolência desses grupos”. (MUTEBA RAHIER, 1998, p. 421-430, 424) No México, os afro-mexicanos reagem aos estereótipos de "feios" e "escuros" focando em casamentos inter-raciais com pessoas de pele mais clara com a esperança de tornar a prole mais clara e, portanto, "melhorar a raça". (CASTELLANOS GUERRERO et al., 2009, p. 217, 233) Na Nicarágua, a expressão "100 negros por um cavalo” traduz diretamente a inferioridade do negro em relação 
ao valor de um único cavalo (STEPHENSON, 2011), dada a visão comum naquela sociedade de que negros são dependentes de drogas e bêbados. (SALINAS MALDONADO, 2009)² No Peru, são comuns as afirmações de que negros são criminosos, que só podem trabalhar em cargos subalternos, que são preguiçosos, que só conseguem raciocinar até o meio-dia, que são delinquentes e que as mulheres negras são prostitutas. Uma matéria feita por jornais peruanos em 2008 revelou um total de 159 adjetivos racistas diferentes para descrever pessoas de ascendência africana. (INFORME, 2008) Na Venezuela, a despeito do orgulho nacional de ser uma raça miscigenada ("café com leche”), a abundância de ditados racistas comumente repetidos inclui a frase "Mate um negro e tenha um dia Pepsi” ("lindo dia”). (GARCÍA, 2010) O vasto repertório de estereótipos raciais sobre afro-venezuelanos inclui: "Negros são perigosos, ladrões, cheiram mal, têm maus hábitos, desonram a imagem de uma empresa [...] não é culpa deles se eles são desse modo [...] negros, quando não fazem na entrada, fazem na saída”. (BOLÍVAR et al., 2009, p. 291-293)

Esses estereótipos raciais também são difundidos pela música popular venezuelana em letras como:

Mulher negra! [...] se você fosse branca e tivesse cabelo liso / minha mãe me disse agoniada para não casar com uma mulher negra porque quando ela dorme parece uma serpente enrolada / uma mulher negra com nariz grande não cozinha para mim porque ela guarda os bocados no buraco do nariz. (BOLÍVAR et al., 2009, p. 293)

Na América Latina, o discurso racial também é usado para demonstrar carinho, o que, inconscientemente, invoca o paternalismo do passado escravista. Por exemplo, a afeição é manifestada por expressões como "este é meu negro" ou "negrinho". Mesmo elogios direcionados a pessoas negras são reservados àquelas que "superaram” a negritude por apresentarem características "superiores”. Tais elogios racializados incluem "ele é negro, mas tem a alma/coração de um branco", “ela é negra, mas é bonita”, “ele é negro, mas é cheiroso e bem cuidado”. Embora essas afirmações não pretendam ser racistas, elas ativam estereótipos raciais sobre a inferioridade racial de negros. De fato, essa visão sobre as pessoas de ascendência africana estão tão arraigadas no tecido social

2 Em que se descreve o racismo na Nicarágua da perspectiva de uma mulher negra do Caribe. 
latino-americano que a presença de afrodescendentes em posições subalternas é tida como algo natural e lógico. Além do mais, a duradoura noção de que "racismo não existe" na América Latina faz com que aqueles que não são afetados pelo discurso de ódio não se disponham a reconhecer os danos causados aos grupos marginalizados.

Ademais, quando exemplos flagrantes de conduta racista recebem atenção da mídia latino-americana, eles são interpretados como atos de indivíduos isolados que não representam a tolerância racial que supostamente faz parte da cultura latino-americana. Essa dicotomia é bem exemplificada por um estudo que mostra que enquanto $87 \%$ dos entrevistados brasileiros não negros manifestaram preconceito racial nas respostas às perguntas da pesquisa, apenas $10 \%$ admitem ter algum tipo de preconceito racial. (DATAFOLHA, 1995) Do mesmo modo, enquanto $89 \%$ de todos os brasileiros afirmam existir racismo no Brasil, somente $4 \%$ admitem ter algum tipo de preconceito racial. (SANTOS; SILVA, 2005, p. 141-145) Dessa maneira, apesar da reputação de o Brasil ser uma terra de relações raciais "cordiais”, os brasileiros, como os demais latino-americanos, possuem bastante consciência das distinções de cor e de sua relevância hierárquica. Um etnógrafo que viajou para o Brasil para estudar a teoria da libertação, mas, ao invés disso, encontrou racismo, relata:

Observei que o problema da cor era uma presença constante na maneira como homens e mulheres se olhavam, escolhiam seus amores e cônjuges, moldavam seus corpos. Estava lá nas rodas de piadas, brincadeiras, insultos e acusações cotidianas. Estava lá no modo pelo qual as pessoas falavam umas com as outras e sobre as outras, em como elas se tocavam, ou não. (BURDICK, 1998, p. viii)

Na verdade, os brasileiros, como a maioria dos latino-americanos, não conseguem imaginar uma versão afro-brasileira de Barack Obama se autodeclarando afrodescendente. (VERISSIMO, 2008) Em resumo, apesar das diferenças regionais na demografia racial e do predomínio da expressão do discurso da miscigenação, em toda América Latina existe uma realidade antinegra comum.

Contudo, a negação latino-americana do racismo está profundamente arraigada nos ambientes racialmente hierarquizados. Esse dualismo foi viabilizado ao longo da história pelo desenvolvimento de comparações estratégicas com o sistema racial estadunidense, com a pretensão de descrever a América Latina como inocente por não ter recorrido ao racismo. Chamo isso de discurso da 
“inocência racial”. Nesse sentido, o Ariel Dulitzky, acadêmico latino-americano na área dos direitos humanos afirma que

Há certa presunção de superioridade moral em relação aos Estados Unidos muito difundida em nossa região. Raramente, uma conversa sobre racismo entre latino-americanos ocorre sem que se mencione a marcada incidência de racismo e discriminação racial que existe na terra dos nossos vizinhos do norte. (DULITZKY, 2005, p. 39, 42-50)

Por exemplo, na pesquisa BBC de 2005 sobre atitudes racistas latino-americanas, a seguinte invocação de inocência racial foi bastante observada:

Não acho que exista muito racismo na América Latina porque somos uma mistura de raças de todos os tipos, europeus, africanos, asiáticos e outras raças que existiram e existirão; mas entendo que exista muito racismo em outras partes, principalmente nos Estados Unidos e na Europa, lá é onde existe mais racismo. (IBEROAMÉRICA, 2005)

Em sua pesquisa sobre racismo no Peru contemporâneo, Suzanne Oboler (2005, p. 75-100) identificou que, assim como na maioria dos países do continente americano, as leis estadunidenses de segregação constituem a definição ideológica do racismo.

A América Latina tradicionalmente se orgulha de um passado sem leis de segregação racial ao estilo da legislação Jim Crow que vigorou nos Estados Unidos. Quando os latino-americanos avaliam as condições raciais de hoje, comparam-nas continuamente com a história de segregação racial estadunidense moldada pelas leis Jim Crow, e fazem afirmações como: "Não existe um racismo violento como em outras partes do mundo, como o neonazismo ou a segregação no sul dos Estados Unidos.” (IBEROAMÉRICA, 2005) “Este é um problema dos americanos." (OBOLER, 2005, p. 85) Por conveniência, o uso dos Estados Unidos como ponto de referência ofuscou a visão da situação de subordinação racial de pessoas de descendência africana na América Latina.

Ademais, a histórica ausência de leis de segregação racial do tipo Jim Crow é usada como justificativa para fazer oposição às demandas contemporâneas dos movimentos negros por políticas sociais racialmente conscientes. (DZIDZIENYO, 2005, p. 279-291) Por exemplo, ao discutir a possibilidade do uso de ações afirmativas no mercado de trabalho colombiano, um observador adverte 
"Isso seria como comprar uma passagem para um conflito que não conhecemos." (GALLO ROJAS, 2009, p. 7) No mesmo sentido, outro colombiano afirma: "Se não queremos criar um conflito racial que não existe neste país, teremos que baixar o tom das reivindicações raciais e propor soluções universais, como a luta contra a pobreza." (RODRÍGUEZ GARAVITO, 2009) ${ }^{3}$ Na mesma esteira, a reação brasileira ao uso de ações afirmativas em algumas universidades é denunciá-las como "a substituição da noção brasileira de democracia racial por uma discriminação positiva, ao estilo estadunidense, que generalizaria a polarização.” (VEGA SFRANI, 2006) A título de ilustração, um manifesto de grande circulação se opondo ao uso de ações afirmativas no Brasil se intitula "Não somos racistas: uma reação aos que querem nos transformar numa Nação Bicolor.” (KAMEL, 2006) Faz pouca diferença para esses críticos que as ações afirmativas, na realidade, tenham se originado na Índia, não nos Estados Unidos.

Todavia, frequentemente ignorado pelas comparações feitas com o passado estadunidense marcado pela legislação Jim Crow, e que favorecem o Estado, é o papel do Estado latino-americano na regulação das relações raciais. Especificamente, com a abolição da escravidão, as nações latino-americanas promulgaram leis de imigração restritivas e promoveram, com recursos estatais, uma política de imigração voltada explicitamente para o branqueamento da população e a proibição da imigração de pessoas de ascendência africana. Através das leis de imigração, afrodescendentes foram recolocados no lugar que ocupavam no período anterior à abolição, o de pessoas marginalizadas. Ademais, o direito costumeiro (por exemplo, a aplicação de regras não escritas aceitas pelo longo período de uso em vez de leis promulgadas e sancionadas) foi também usado como uma ferramenta de exclusão racial na América Latina.

\section{Direito costumeiro de regulação racial}

Não temos racismo porque aqui o negro conhece seu lugar. ${ }^{4}$

O direito costumeiro é particularmente relevante para examinarmos os projetos raciais do Estado porque frequentemente é necessária alguma coordenação

3 Em que cita Daniel Mera, diretor da Fundación Color.

4 Um ditado brasileiro sobre relações raciais. (MARTINS, 2008, p. 37-46) 
social para que convenções sociais sejam ratificadas. Isso pode ser surpreendente para os acadêmicos do direito de hoje, os quais raramente se aprofundam nas sutilezas do direito costumeiro, uma vez que cederam essa área de pesquisa aos antropólogos. (CHANOCK, 1991, p. 52-70, 53) Esse fato pode ser ainda mais surpreendente na área de estudos latino-americanos, na qual a história do direito costumeiro frequentemente é colocada em segundo plano, sem falar na aversão que existe em relação ao direito costumeiro no sistema jurídico atual, dominado por códigos civis. (ANZOÁTEGUI, 2001, p. 13)

Todavia, em linha com a tradição jurídica de direito romano adotada pelos países da América Latina, o direito costumeiro é uma fonte de direito desde as origens dos sistemas de direito civil e, nesse sentido argumento que não deve ser negligenciado como mecanismo de controle racial. (JOLOWICZ, 1967; PINTO, 1982, p. 126; WATKIN, 1999) Especificamente, o conceito de direito romano de ius non scriptum (direito não escrito) descreve as regras que surgem das práticas costumeiras não escritas e que se tornaram obrigatórias com o decurso do tempo, em contraposição ao ius scriptum (direito escrito), ou seja, regras escritas que foram deliberadamente elaboradas pelo legislador. Os usos do direito consuetudinário no direito civil, empregados aqui, ecoam as origens romanas como na conduta tácita de uma comunidade consagrada pelo uso prolongado. (WATSON, 1984, p. 561-576) Por exemplo, vários acadêmicos do direito observaram que o costume foi uma fonte de direito útil para o desenvolvimento da história do direito colonial espanhol no que diz respeito ao comércio e à mineração (MIROW, 2004), além de ter sido relevante para o desenvolvimento do direito latino-americano, inclusive o direito brasileiro. (ANZOÁTEGUI, 2001; CASTELLUCCI, 2008, p. 1-32; PINTO, 1982, p. 45; SAVASTANO, 2009, p. 651-667) As tradições de direito civil latino-americanas, fundadas no conceito romano de ius non scriptum, até os dias atuais reconhecem o costume como uma fonte do direito, ao lado das leis e regulamentos administrativos. (MERRYMAN; PÉREZ-PERDOMO, 2007) Apesar de o costume não ser necessariamente uma fonte do direito predominante no direito latino-americano, vale notar que o direito costumeiro é reconhecido como uma fonte do direito.

A visão desta obra sobre a aplicabilidade histórica do direito costumeiro à população em geral contrasta com a visão contemporânea desse sistema jurídico, como uma prática mais restrita de aplicação de normas jurídicas a um grupo específico ou a um subgrupo da população, como no caso das populações 
indígenas ou tribos africanas. (GOODRICH, 1986, p. 64) Essa dupla conotação do direito costumeiro também era adotada no contexto do direito romano, segundo o qual o direito costumeiro era aplicado às relações entre os cidadãos romanos em geral e também eram consideradas aplicáveis normas costumeiras oriundas dos demais subgrupos populacionais dentro do próprio Império Romano. (VINOGRADOFF, 1925, p. 23)

A concepção moderna de direito costumeiro como sistema específico de subgrupos populacionais indígenas, tal como discutido por autores como Rachel Sieder e muitos antropólogos que a ele atribuem o nome de "direito tradicional", não é a concepção adotada neste livro. (FITZPATRICK, 1984, p. 20-27; SIEDER, 2002) Isso porque o foco atual em direito costumeiro indígena enfatiza como sistemas jurídicos paralelos, o da população majoritária hegemônica e o da população indígena minoritária, podem apresentar perigo de um conflito de normas entre o Estado e as práticas costumeiras de um subgrupo indígena da população, como no caso dramático em que o direito costumeiro na África colonial serviu aos administradores da elite branca. (CHANOCK, 1989, p. 72-88) Pelo contrário, este livro busca elucidar como o uso implícito do direito costumeiro geral pelo próprio Estado, para que este faça valer uma ordem social particular, em vez de se debruçar sobre os desafios apresentados ao Estado por práticas costumeiras de grupos específicos. Neste livro, a noção de direito costumeiro geral empregada remonta à noção de Bentham de direito costumeiro como algo que "esconde os interesses sinistros da elite dominante". (PERREAU-SAUSSINE; MURPHY, 2007, p. 5) Em resumo, o direito costumeiro pode representar a imposição de normas obrigatórias por algumas pessoas em relação a outras. (CHANOCK, 1985)

O direito costumeiro não precisa ser codificado posteriormente para que se torne obrigatório. (SHELEFF, 1999, p. 378, 385) Em verdade, as fontes romanas, como os institutos de Justiniano, consideravam o costume como direito quando as comunidades o aceitavam como tal conforme evidenciado pela aplicação das normas formais e informais de direito costumeiro. (BEDERMAN, 2010, p. 17) Na realidade, quando o direito costumeiro está totalmente integrado a uma sociedade, constituindo uma prática estatal, existe pouco incentivo para que os costumes sejam codificados. O que mais importa é se existe um sentimento de obrigação jurídica regendo uma determinada conduta, vinculando-a ao costume e exigindo conformidade com o mesmo. Disso decorre que a aceitação de uma norma social na condição de norma jurídica passa a ser comprovada pelo uso dos recursos estatais para fazer 
valer tais regras no âmbito geral. (PETERSEN, 1995, p. 174) No contexto latino-americano, o uso dos recursos estatais (por exemplo, o poder de polícia aplicando segregação racial e a alocação de incentivos financeiros para promover a imigração de europeus) é o fator-chave para transformar convenções sociais em direito costumeiro. Isso porque o direito costumeiro se refere a um subgrupo de normas sociais "escolhidas para serem aplicadas de forma especial”. (MURPHY, 2007, p. 76)

Avaliar o tratamento conferido aos afrodescendentes através das lentes do direito costumeiro ajuda a elucidar a dimensão "jurídica" da história racial latino-americanas. Por exemplo, os depoimentos de afro-brasileiros feitos no sul do Brasil, no período pós-abolição, amplamente evidenciam os costumes arraigados de segregação racial - nas ruas, praças, parques e jardins públicos, tanto nas capitais como no interior -, mantidos pela polícia, a qual costumava prender os afro-brasileiros. Tais práticas podem ser caracterizadas como direito costumeiro na medida em que elas eram impostas por meio de sanções físicas e agentes estatais se sentiam obrigados a aplicar as normas vigentes na comunidade, a despeito da inexistência de um dispositivo legal expresso ou uma declaração legal explícita de que os costumes eram direito. Chamo isso de "direito costumeiro de regulação racial" para demonstrar as maneiras pelas quais a norma social de exclusão racial efetivamente operou como um sistema jurídico, no qual os recursos estatais e de coerção foram utilizados para garantir a marginalização de pessoas de ascendência africana. Dessa maneira, o uso que faço do direito costumeiro enfoca as maneiras pelas quais as regras de exclusão racial foram mais do que convenções sociais, eram equivalentes ao direito. Levar em conta a importância do papel do direito costumeiro aumenta nossa compreensão sobre a regulação racial na América Latina.

As discussões acadêmicas sobre direito costumeiro na América Latina frequentemente observam que muitos países na região não conferem status de direito costumeiro às práticas consideradas contra legem (contrárias ao direito), ou seja, contrárias ao direito legislado. (GUZMÁN BRITO, 1987) Ao mesmo tempo, acadêmicos também observam que vários exemplos de direito costumeiro reconhecido, não obstante, transgridem o direito legislado. (PINTO, 1982, p. 126-128; SANTAMARÍA, 2009, p. 249-264) No caso específico do direito costumeiro de regulação racial, o único argumento para que o mesmo seja contra legem, portanto sem status jurídico, seria a existência de normas igualitárias que proliferaram nas constituições da região após as respectivas 
independências. Esse argumento, entretanto, pode ser facilmente descartado se considerado que as provisões igualitárias eram dirigidas aos títulos de nobreza e à abolição de privilégios monárquicos remanescentes.

Por exemplo, uma disposição igualitária típica no período pós-colonial pode ser encontrada na Constituição Argentina de 1853, que declarava:

A nação argentina não admite prerrogativas de sangue ou de nascimento; privilégios pessoais e títulos de nobreza não existem. Todos os habitantes são iguais perante a lei, e admissíveis a qualquer emprego público desde que atendam às exigências do cargo. (ARGENTINA, 1853, art. 16)

A aplicação restritiva, no século XIX, da igualdade constitucional às questões de nobreza, também é percebida nas disposições que excluíam analfabetos e pobres do direito de votar, uma vez que seriam pessoas de classe inferior que, portanto, não deveriam ter garantidos os plenos direitos de cidadania. Na medida em que a igualdade constitucional da América Latina do século XIX se limitou a homens brancos, o direito costumeiro de regulação racial não pôde ser considerado uma derrogação contra legem da norma constitucional. Ademais, a América Latina do século XIX considerava as constituições documentos políticos sem efeitos jurídicos diretos e imediatos, salvo se houvesse lei regulando suas normas e, assim, nunca questionou se os costumes de regulação racial seriam considerados contra legem e, portanto, não obrigatórios juridicamente.

Debates sobre direito costumeiro normalmente se ocupam de como costumes, enquanto direito não escrito, que podem ser aplicados diretamente em juízo, ou como normas de um subgrupo, que podem coexistir na condição de direito costumeiro em um sistema soberano mais amplo de leis formais sancionadas por um soberano. Este livro examina somente o uso implícito do direito costumeiro fora do judiciário, por atores estatais, visando ao fortalecimento do aparato que sustenta a hierarquia racial existente. Os capítulos 2 e 3 analisam as práticas costumeiras que o Estado empregou no período após a abolição para manter a segregação racial, excluindo as pessoas de ascendência africana de lugares públicos, impondo normas racistas nas escolas públicas, estabelecendo normas racistas contra religiões de matriz africana e estruturando recenseamentos que marginalizavam as pessoas de ascendência africana, primeiro na América Hispânica e depois no Brasil. 
O exame do amplo repertório de práticas costumeiras racialmente excludentes, juntamente com a legislação e os subsídios oferecidos às políticas de restrição à imigração, faz cair por terra a noção de que os Estados latino-americanos não tiveram regulação racial e, portanto, eram inocentes. Sem dúvida, as particularidades do contexto legal latino-americano não podem ser diretamente comparadas com a história de segregação racial nos Estados Unidos por meio das leis Jim Crow. Apesar disso, vale ressaltar como a ação estatal na América Latina voltada para a subordinação racial teve um efeito similar na marginalização de pessoas de ascendência africana na região. De fato, o verdadeiro mal das restrições raciais da legislação Jim Crow estadunidense não residia tanto no fato de que as leis de segregação foram escritas e codificadas, mas no fato de evidenciarem a ação estatal de discriminação racial revelada por essas leis. Similarmente, o direito costumeiro latino-americano traz à tona o papel pernicioso do Estado na regulação racial.

Enquanto é verdade que as assimetrias históricas e sociopolíticas na região são enormes, o objetivo aqui é explicitar aspectos comuns, frequentemente desprezados, de como a ordem jurídica latino-americana funda-se enormemente no privilégio racial e continua produzindo significativas disparidades raciais em várias áreas políticas e socioeconômicas, como detalhado no capítulo 4. Por essa razão, o livro enfoca o estabelecimento do direito costumeiro racialmente excludente no século XIX, para em seguida abordar as preocupações contemporâneas com a estratificação racial. Menos atenção é dada aos anos seguintes, nos quais a desigualdade racial permaneceu intacta, para dar mais atenção ao modo como o legado do direito costumeiro de regulação racial afeta os afrodescendentes hoje.

Desse modo, este livro busca romper a narrativa tradicional de que a América Latina tem um passado jurídico racialmente benigno e reexamina sua importância para o atual desenvolvimento de leis de igualdade racial na região. Dada a resistência das elites às políticas públicas de igualdade racial patrocinadas pelo Estado, é essencial fornecer um quadro completo do envolvimento estatal na manutenção da hierarquia racial. Por seu turno, o panorama elaborado neste livro oferece suporte adicional para as políticas de igualdade racial latino-americanas que estão sendo contestadas no judiciário e no debate público. Ao detalhar a cumplicidade histórica dos estados latino-americanos em criar e manter hierarquias raciais, o livro joga por terra o mito da inocência racial da América Latina e também apoia a reivindicação dos movimentos por justiça social decorrente de um engajamento estatal direto na promoção da igualdade racial. Deve 
ficar claro que o estudo das ações estatais feito nesta obra não se limita ao esforço de procurar justificar a participação estatal na promoção de políticas de igualdade racial por causa do envolvimento histórico do Estado na produção de desigualdade racial. A desigualdade racial é uma preocupação premente que deve ser levada em consideração pelos agentes estatais a despeito do grau de participação do Estado na história da produção de desigualdade racial. A partir dessa perspectiva, o livro aborda de maneira mais ampla o poder do discurso da ação estatal para os indivíduos que participam de movimentos sociais, em uma tentativa de acabar com a ideia de inocência racial por parte do Estado que, por seu turno, impede que a sociedade efetivamente busque igualdade racial. Nesse sentido, o presente livro serve não somente como uma narrativa de como o direito foi utilizado na construção da hierarquia racial latino-americana, mas também como uma avaliação da importância das iniciativas estatais contemporâneas com o objetivo de erradicar o racismo na região.

O capítulo 5 examina as várias iniciativas legais que têm sido adotadas na América Latina para superar o racismo. Constituições multiculturais, leis de titulação coletiva de terras, leis contra a discriminação no mercado de trabalho, leis sobre acesso a lugares públicos, leis sobre discursos de ódio e o direito internacional dos direitos humanos serão analisados nesse capítulo. Atenção especial será dirigida à esperança desproporcional que é depositada no direito criminal enquanto resposta jurídica à longa história de marginalização e negação do racismo. As dificuldades em potencial de lidar de forma plena com a discriminação racial dentro do contexto criminal serão discutidas juntamente como enfoque exclusivamente interpessoal, próprio desse tipo de abordagem, em detrimento de uma abordagem institucional muito mais ampla que trate da discriminação racial sistêmica.

O capítulo 6 examina a liderança brasileira no uso de ações afirmativas na América Latina, esmiuçando a trajetória das políticas de ações afirmativas baseadas em raça, a partir de 2001 no Brasil. Em seguida, investiga a crescente oposição feita a esse tipo de política devido ao aumento de ações afirmativas baseadas em raça em instituições de ensino superior de elite, bem como as demandas judiciais apresentadas contra essas políticas. O capítulo enfatiza os sucessos dos programas, portanto serve como referência para os demais países da América Latina, mas também examina como a visão míope da região sobre o papel do Estado na criação da subordinação racial pode atrapalhar o estabelecimento de políticas de ação afirmativa mais amplas. 
A conclusão do livro, o capítulo 7, traz insights de como a análise da realidade latino-americana pode ser útil para os movimentos de justiça racial estadunidenses. A luta afro-latino-americana para desvelar o discurso de um Estado racialmente inocente, o qual camufla desigualdades raciais persistentes, pode ajudar a esclarecer a complexa realidade racial nos Estados Unidos nos dias de hoje. A bem-sucedida batalha dos movimentos por direitos civis contra as leis Jim Crow agora coloca as minorias raciais nos Estados Unidos em situação análoga à situação vivida pelos afrodescendentes na América Latina: ter que lutar contra uma hierarquia racial não baseada em uma discriminação jurídica formal. 


\section{América Hispânica branqueia a raça - leis (não) escritas de branqueamento e mestiçagem}

Os países da América Hispânica, pouco tempo depois de terem declarado a abolição de todas as formas de escravidão (principalmente entre os anos de 1850-1886), também se deparam com o crescimento da eugenia, um movimento pseudocientífico que buscava melhorar a raça humana preservando a pureza genética dos brancos. (GALTON, 1869) Assim, qualquer investigação do papel do direito do século XIX na regulação racial na América Latina deve considerar a influência da eugenia na região. Este capítulo avalia o papel da eugenia nas políticas estatais latino-americanas e as práticas costumeiras de exclusão racial delas resultantes. Para demonstrar os padrões regionais seguidos pelo direito costumeiro de regulação racial, este capítulo fornece uma visão geral das leis costumeiras latino-americanas de inspiração eugênica, ao passo que o capítulo 3 apresenta um estudo de caso minucioso do Brasil com o fim de detalhar o desenvolvimento do direito costumeiro de regulação racial no maior país da América Latina, o qual conta com a maior densidade de afrodescendentes.

Noções eugênicas europeias associaram a prevalência de não brancos na América Hispânica ao atraso de nações mestiças. (MARTíNEZ-ECHAZÁBAL, 1998, 
p. 23-24) Entre 1880 e 1930, intelectuais hispano-americanos encontraram suporte para seu próprio elitismo racial em teorias raciais europeias, como a da eugenia, que afirmava a inferioridade inata dos não brancos. (HELG, 1990, p. 37-38) Tendo em conta o maior número de pessoas de ascendência africana e indígena na América Hispânica, a região desenvolveu sua própria forma de eugenia a partir dos conceitos de branqueamento e mestiçagem. A mestiçagem corresponde à crença no uso da mistura racial para clarear a cor da pele da nação e torná-la mais branca, assim promovendo harmonia racial. Essa compreensão teórica ampla de mestiçagem, que é o foco deste capítulo, coexistiu com uma noção mais estrita de mestiçagem como mistura racial entre brancos e indígenas, que criou a identidade racial mestiça.

O branqueamento é um conceito de um significado individualizável, pessoal, e outro nacional, mais amplo. No nível individual, o branqueamento gira em torno do desejo de uma aparência branca e a ambição de ter filhos mais claros por meio de relações inter-raciais. Acredita-se que filhos de pele mais clara terão mais oportunidades de mobilidade social. Ao mesmo tempo, a valorização individual da branquitude é muito mais influenciada pela promoção nacional da branquitude, mais bem exemplificada pelas representações das relações inter-raciais como aquelas que "melhoram a raça". No nível nacional, o branqueamento é um conceito que descreve não só uma campanha concreta, de construção nacional e patrocinada pelo Estado para branquear a população, mas também a ideologia racial geral que valoriza a branquitude. Portanto, o branqueamento é um projeto mais amplo do que as oportunidades concedidas no período colonial ao seleto grupo de pessoas de ascendência africana na classe alta, as quais podiam alterar oficialmente sua identificação racial por meio de uma petição e do pagamento à Coroa Espanhola por um certificado de branquitude conhecido como cédula de gracias al sacar. (KING, 1951, p. 640-647) Isso porque o branqueamento, ao contrário desses certificados, buscava beneficiar toda a nação com uma imagem branca, e não apenas as pessoas de ascendência africana que buscavam ter os mesmos direitos e privilégios dos colonos brancos.

Apesar de distintas, todas as tentativas feitas para branquear a população ou a imagem da nação nos países da América Hispânica foram calcadas na crença eugênica de superioridade branca. A base "científica" da eugenia divergiu na América Hispânica se levarmos em consideração os enfoques europeu e estadunidense. Na Europa e nos Estados Unidos, o livro de Gregor Mendel 
de 1866, Princípios da Hereditariedade, foi usado para desenvolver uma teoria eugênica que postulava que pessoas bem-sucedidas tinham uma boa carga genética, ao passo que pessoas e grupos em desvantagem tinham uma má carga genética, sendo que nenhum nível de desenvolvimento social poderia remediar tal fato; logo a pureza dos bons genes deveria ser protegida a qualquer custo. (STEPAN, 1991, p. 27-28) Em contraste, a abordagem da América Hispânica para a eugenia foi culturalmente adaptada e favoreceu a conceituação que se assemelhava às primeiras ideias sobre hereditariedade de Jean Baptiste Pierre Lamarck. (BURKHARDT, 1977) A teoria de Lamarck considerava que forças externas influenciavam a hereditariedade de modo que as características que um indivíduo adquiriu ao se adaptar a um ambiente poderiam ser herdadas por gerações futuras. Ainda que mais tarde a teoria de aquisição genética de Lamarck tenha sido rechaçada, a mesma teve um grande apelo para os países da América Hispânica que buscavam amenizar presunções negativas, presunções europeias de que sua numerosa população de pessoas de ascendência africana e indígena tornava a nação inferior. Em vez de se ver condenado pelo predomínio das "raças inferiores" que a eugenia de Mendel considerava irremediável, o lamarckismo, mais flexível, considerava que com intervenção externa novas características poderiam ser adquiridas e, então, herdadas pelos descendentes. Consequentemente, muitos países da América Hispânica aprovaram leis higienistas para sanar e melhorar as classes inferiores. (STEPAN, 1991, p. 85-89) Ao mesmo tempo, legislação exigindo exames médicos pré-nupciais foi instituída para desmotivar a reprodução de classes inaptas, consideradas como mais propensas a doenças venéreas, alcoolismo, doenças mentais e doenças crônicas. (STEPAN, 1991, p. 122-128)

Além do mais, a noção de aquisição genética de Lamarck, intuitivamente, fornecia suporte indireto para o conceito de mestiçagem, segundo o qual as relações inter-raciais entre brancos e negros fariam com que a prole resultante adquirisse determinada branquitude e todos os atributos positivos socialmente associados a ela. (ALONSO, 2004, p. 462; TELLES, 2004, p. 28) A partir desse raciocínio, ao longo do tempo, o gene da branquitude presumivelmente "mais forte" predominaria na população e o número de pessoas negras diminuiria. Por essa razão, a noção eugênica de miscigenação racial construtiva da América Hispânica foi considerada uma contribuição original para um campo em que tradicionalmente a mistura racial era vista como algo degenerativo. (STEPAN, 1991, p. 170) Essa característica está bem refletida 
na citação do influente filósofo mexicano José Vasconcelos, que ressaltava os benefícios de uma nova raça mestiça, chamada por ele a "raça cósmica”, pela qual "os tipos inferiores da espécie serão absorvidos pelo tipo superior. Dessa maneira, por exemplo, o Negro poderia se redimir, e passo a passo, por extinção voluntária, os grupos mais feios darão caminho para os mais bonitos”. (VASCONCELOS, 1997, p. 30)

Em resumo, tendo como pano de fundo a pseudociência da eugenia lamarckiana, branqueamento e mestiçagem operaram juntos e independentemente para reforçar o processo de construção de uma nação no período posterior à emancipação com vistas a reduzir a negritude e diluí-la na nova raça criada. O branqueamento na abordagem do ideal de embranquecimento gradual de uma geração para a outra ofereceu meios para eliminar parte do estigma de atraso e para fazer oposição filosófica à eugenia europeia. Por sua vez, a mestiçagem rebatia o rótulo de nação impura valendo-se de uma bem construída ilusão de superioridade moral por ter resolvido problemas raciais por meio da minimização das diferenças raciais e da criação de uma democracia racial, cujas raças estariam mescladas. A maneira pela qual diferentes países da América Hispânica responderam à eugenia variou conforme o grau em que foram capazes de atrair imigrantes europeus e o tamanho de suas populações indígenas. Alguns países focaram somente no projeto de branqueamento (Argentina, Uruguai e Chile), outros voltaram mais atenção para a articulação de um orgulho acerca da mistura de raças que incluía a negritude (Colômbia, Cuba e Venezuela), ou uma "mestiçagem monocultural" que se fundava na mistura de indígenas com brancos com uma exclusão total de negros (Equador e México). (MUTEBA RAHIER, 2008, p. 148-182) Mesmo assim, como a discussão sobre as particularidades dos vários países irá mostrar, todas as estratégias foram essencialmente orientadas por um sentimento antinegro.

\section{Argentina como a síntese do branqueamento}

A imigração foi frequentemente a primeira área de atuação estatal para a promoção dos projetos de construção nacional baseados na mestiçagem e no branqueamento. De fato, debates sobre as políticas de imigração na América Hispânica foram quase sempre concebidos a partir da ideia de raça. (BLETZ, 2003, p. 9) A Argentina se destaca por ter focado exclusivamente na implementação do branqueamento ao intensificar a imigração de europeus. Depois da 
emancipação constitucional dos escravos em 1853, a imigração fez duplicar a população argentina entre 1869 e 1895, passando de 1,8 milhão para 4 milhões. Em 1914, a população havia dobrado novamente, fazendo com que $30 \%$ da população fosse nascida no estrangeiro. O enfoque argentino na imigração europeia em particular é demonstrado pelo fato de que somente entre 1880 e 1900 quase um milhão de europeus migraram para a Argentina. (REID ANDREWS, 1980, p. 20,178) Esse número só é superado pela taxa de imigração europeia para os Estados Unidos. (BLETZ, 2003, p. 79) A explosão imigratória para a Argentina não foi mera coincidência, mas o resultado de um esforço concreto do governo daquele país.

A Constituição original de 1853 incluiu um dispositivo voltado à promoção da imigração:

O governo federal deve fomentar a imigração europeia; e não deve restringir, limitar ou onerar com tributo de qualquer espécie a entrada no território argentino de estrangeiros que venham com o propósito de arar a terra, aperfeiçoar a indústria e introduzir e ensinar as artes e as ciências. (ARGENTINA, 1853, art. 25)

Além do mais, um provimento constitucional subsequente explicitamente declarava que:

Estrangeiros gozam no território nacional de todos direitos civis dos cidadãos; podem exercer indústria, comércio e profissão; possuir bens, comprar e vender bens imóveis; navegar nos rios e costas; praticar livremente sua religião; testar e casar conforme as leis. Não são obrigados a aceitar a cidadania, nem a pagar contribuições compulsórias extraordinárias. Podem obter nacionalidade depois de residir dois anos no país; mas, as autoridades podem reduzir o período de tempo para aqueles que assim o solicitarem, alegarem e provarem serviços prestados à República. (ARGENTINA, 1853, art. 20)

Depois disso, Domingo Sarmiento, presidente da Argentina de 1868 até 1874, demonstrou explicitamente o interesse do governo na imigração europeia com o propósito de embranquecer a população, e declarou que "corrigiria o sangue indígena com novas ideias que acabariam com o medievalismo” do país. (REID ANDREWS, 1980, p. 103) Com efeito, o branqueamento por meio da imigração buscava modernizar o país com o aumento da reserva genética 
"capaz" de realizar a modernização. O mandato constitucional pela imigração europeia se exteriorizou inclusive na alocação de subsídios públicos para atrair os imigrantes para a Argentina. (REID ANDREWS, 2004, p. 136)

Os imigrantes europeus foram bem recebidos no mercado de trabalho e, simultaneamente, os afro-argentinos foram excluídos do mesmo. Em 1914, os estrangeiros na Argentina dominavam quase todas as categorias de trabalhadores qualificados, a despeito de representarem apenas 30\% da população. (KLEIN, 1983, p. 323) Os italianos, que fizeram parte das primeiras grandes ondas imigratórias e, por conseguinte, predominavam sobre a população estrangeira na Argentina, representavam uma grande porcentagem dos proprietários de terra. O censo de 1914 indicou que 25\% dos italianos de 20 anos ou mais eram proprietários (um dado que se aproxima da média nacional). (KLEIN, 1983, p. 318321) Em Buenos Aires, conforme o censo de 1909, os imigrantes italianos possuíam $38 \%$ dos estabelecimentos comerciais na cidade, a despeito de representar somente $22 \%$ da população da cidade. (KLEIN, 1983, p. 321) Os números de Buenos Aires são particularmente relevantes se levarmos em consideração a densidade da população afro-argentina na cidade à época. (REID ANDREWS, 1980, p. 64-200) Em 1887, os italianos eram 32\% da população da cidade, representavam $53 \%$ da força de trabalho na indústria e eram 57,5\% dos proprietários de estabelecimentos industriais. Em contraste, os nascidos na Argentina, que perfaziam $47 \%$ da população da cidade, representavam apenas pouco mais de $20 \%$ dos proprietários e trabalhadores no comércio, $16 \%$ da força de trabalho na indústria e menos de $10 \%$ dos proprietários de estabelecimentos industriais. (BAILY, 1983, p. 284) Esses indicadores contundentes de quão bem os imigrantes italianos rapidamente se integraram à economia nacional argentina apoiam a hipótese de que a elite argentina considerava a imigração europeia de italianos como uma bem-vinda portadora da civilização. Com o influxo de imigrantes na população argentina e as relações inter-raciais entre esses e a população indígena, uma "população biologicamente superior" poderia ser criada. Simultaneamente, a população afrodescendente, "vadia, preguiçosa”, foi substituída no mercado de trabalho por imigrantes europeus. Muitas das categorias profissionais que afro-argentinos desempenhavam outrora foram dominadas por imigrantes europeus. A substituição da mão de obra negra por imigrantes europeus foi um fenômeno tão generalizado que alcançou até as forças armadas (uma área tradicionalmente aberta a homens afrodescendentes). (REID ANDREWS, 1980, p. 20-183) Atualmente, os afro-argentinos compõem aproximadamente $5 \%$ de 
toda população nacional (DOWNES, 2006) e estão tão marginalizados que Carlos Menem, presidente argentino de 1989 a 1999, uma vez declarou: "Não, nós não temos negros. O Brasil tem esse problema”. (GABINO, 2007)

\section{Apoio do Estado à imigração europeia em toda a América Hispânica}

Apesar de a Argentina poder ser considerada o exemplo mais bem acabado de substituição de pessoas de ascendência africana no mercado de trabalho por imigrantes europeus, esse exemplo está longe de ser uma aberração na América Hispânica e Caribe. Como resultado de vários esforços legislativos e do discurso público que fomentava a imigração europeia, o Brasil, Cuba e o Uruguai, juntamente com a Argentina, receberam mais de $90 \%$ dos 10 a 11 milhões de europeus que chegaram entre 1880 e 1930 às Américas. (REID ANDREWS, 2004, p. 129, 136) Antes disso, o Congresso da Grã-Colômbia (constituído pelos atuais Colômbia, Equador, Panamá e Venezuela, até sua dissolução em 1830) buscou incentivar a imigração europeia através da transferência de terras públicas. (SAFFORD, 1991, p. 2)

No Uruguai, que em 1880 tinha uma população de apenas 520 mil, o fluxo de imigrantes europeus entre 1880 e 1930 foi de 580 mil pessoas. (REID ANDREWS, 2010, p. 8) Em Montevidéu, o crescimento da população da cidade foi de 58 mil pessoas para 309 mil pessoas entre 1880 e 1908, o que pode ser diretamente atribuído ao afluxo de imigrantes europeus. Em verdade, em 1908 os moradores nascidos no exterior representavam $30 \%$ da população da cidade e sua proporção entre os trabalhadores da cidade era ainda maior. (REID ANDREWS, 2010, p. 40-42) Em 1925, publicações oficiais proclamavam o Uruguai como "totalmente de origem europeia", a despeito da existência de um expressivo número de jornais vibrantes e ativos publicados para a comunidade afro-uruguaia. (REID ANDREWS, 2010, p. 3-5)

De fato, tais periódicos negros são centrais para a documentação do papel do Estado uruguaio na produção da segregação racial no período posterior à abolição da escravidão. Jornais afro-uruguaios noticiavam sobre a frequência com que escolas públicas não admitiam crianças afrodescendentes e a exclusão racial em muitos cargos públicos, incluindo a polícia. (REID ANDREWS, 2010, p. 83-96) Claramente o Estado falhou em intervir para prevenir a exclusão racial de afro-uruguaios de instalações públicas, como hotéis, teatros, restaurantes, salões de dança e cafés. (REID ANDREWS, 2010, p. 105-109) Até 
que, em 1856, os afro-uruguaios passaram a reconhecer seu contexto racial como explicitamente segregado e puderam dizer que "segregação é o que nos preocupa e é o que nós queremos abolir.” (REID ANDREWS, 2010, p. 110) ${ }^{1}$

$\mathrm{Na}$ Venezuela, depois da emancipação dos escravos em 1854, o governo e os principais intelectuais expressaram abertamente o desejo por uma imigração europeia que permitisse efetuar uma "transfusão de sangue". (WRIGHT, 1979, p. 3) Os imigrantes preferidos eram da Irlanda, Alemanha, Ilhas Canárias e depois, da Itália. (ÁLVAREZ DE FLORES, 2006-2007, p. 90) Tentativas do governo para levar imigrantes europeus foram depois seguidas, em 1891, por uma legislação que proibia não brancos de entrarem no país. (PARÍS GARCÍA, 2002, p. 27) A política de imigração seletiva foi então incorporada na Constituição de 1906 com a proibição de imigração de qualquer afrodescendente. (WRIGHT, 1970, p. 22) O governo venezuelano foi também bastante claro em suas declarações oficiais sobre sua oposição à imigração negra, como exemplificado pela linguagem utilizada no seguinte comunicado do Ministério do Comércio: "A mera ideia de tal, ainda que sejam apenas rumores, já justifica nosso alarme. A introdução de indivíduos dessa raça, nas condições em que viriam, constitui uma verdadeira imigração, e não é essa classe de imigrantes de que a Venezuela precisa”. (WRIGHT, 1974, p. 325-347)

Por conseguinte, mesmo a chegada de marinheiros afro-estadunidenses foi considerada perigosa e os pedidos de desembarque da tripulação na costa venezuelana eram frequentemente negados. (WRIGHT, 1974, p. 337) A proibição legal da imigração não branca na Venezuela foi reafirmada com a lei de imigração de 1836, a qual instituiu a comissão de imigração para funcionar como intermediária entre os interesses mineiros, industriais e agrícolas venezuelanos e as autoridades emigratórias em vários países europeus. (WRIGHT, 1979, p. 8-9)

Como a Venezuela, a Costa Rica proibiu, em 1862, a imigração de pessoas de ascendência africana (e descendentes de chineses também) ao mesmo tempo em que promovia imigração de brancos com um decreto de 1896 autorizando o financiamento governamental anual de programas de incentivo à imigração europeia. (SOTO QUIRÓS, 2003, p. 2, 4) A Colômbia, o México e o Peru também aprovariam leis similares com o objetivo de estimular a imigração branca e impedir a imigração de negros, asiáticos e indígenas. (GONZÁLEZ

1 Citando Suárez Peña, presidente, em 1956, da organização afro-uruguaia Associación Cultural y Social Uruguay. 
NAVARRO, 1970, p. 145-69; VÁSQUEZ, 1970, p. 73-95; WADE, 1993, p. 11$12,15)$ Desse modo, as leis de imigração racialmente restritivas da América Latina tinham fins similares aos da lei de imigração estadunidense de 1924. Similarmente, a lei estadunidense restringiu a imigração com base em critérios de origem nacional e estabeleceu cotas que favoreciam a imigração de europeus procedentes do Ocidente e do norte. (ESTADOS UNIDOS, 1924)

A Colômbia, o Peru e a Venezuela efetivamente subsidiaram imigrantes europeus, com recursos para deslocamento e com benefícios fiscais. (MARTÍNEZ, 1998, p. 3; REID ANDREWS, 2004, p. 284) Os memorandos do governo da República Dominicana declaravam abertamente que os europeus eram os imigrantes desejados. (ELSON SIMMONS, 2009, p. 26) Como resultado, o governo celebrou contratos de trabalho com esses imigrantes e também lhes distribuiu terras. (HOETINK, 1970, p. 96-121) Além do mais, o governo dominicano orientou seus agentes diplomáticos na França, Holanda e Alemanha para fomentarem a imigração para Santo Domingo. No Equador, além de conceder vastas quantidades de terras e financiar o custo da viagem da Europa, o governo aprovou legislação permitindo que os assentamentos de europeus tivessem um significativo grau de autonomia em relação aos seus próprios municípios. (FOOTE, 2006, p. 265)

Da mesma forma, a Cuba do período posterior à independência buscou atrair imigrantes da Espanha e concedeu-lhes subsídios para incentivar a imigração, além de conceder terras e benefícios fiscais. (GOTT, 2005, p. 54) A campanha pela imigração europeia em Cuba foi energicamente conduzida pelos principais intelectuais cubanos, como José Antônio Saco, que queria que imigrantes da "raça branca" superior colonizassem Cuba. (GUEVARA, 2000, p. 50) Ensaístas cubanos da época clamavam que a imigração branca fosse promovida e que imigrantes não brancos fossem rigorosamente proibidos. De fato, um panfleto intitulado "La extinción del negro" projetava um futuro brilhante para Cuba, uma vez que "a raça negra irá desaparecer de nosso ambiente" com o aumento da imigração. (MUSTELIER, 1912) Quase um milhão de espanhóis foram para Cuba depois da independência, mais do que nos quatro séculos de regime colonial espanhol, representando 95\% do número total de pessoas que entraram no país até a década de 1920. (MASFERRER; MESA-LAGO, 1974, p. 348-384) Como resultado, dados censitários do período entre 1899 e 1943 refletem a participação dos negros nos setores mais baixos e mais mal pagos da economia, como na agricultura e nos serviços pessoais. (DE LA FUENTE, 
1995, p. 155) Durante essa época, os afro-cubanos foram sistematicamente excluídos da academia e dos processos eleitorais. (HELG, 1990, p. 53)

Quando os afro-cubanos descontentes com a situação tentaram formar seu próprio partido político em 1910, intitulado “el Partido Independiente de Color”, seus líderes foram presos e processados por conspirarem para implantar uma "Ditadura Negra”. (HELG, 1997, p. 63) Então, o senado cubano aprovou uma lei conhecida como Lei Morúa, que proibia a formação de partidos políticos a partir de critérios raciais. (AGUILAR, 1993, p. 21, 44) Quando o grupo negro organizou o partido político, desafiando a Lei Morúa, a repressão do governo, que ficou conhecida como a "Guerra das Raças de 1912”, foi violenta, expressiva e voltada para o objetivo nacional do branqueamento. (HELG, 1995, p. 193) Os afro-cubanos protestaram contra a medida e manifestaram frustração com seu baixo status econômico quebrando propriedades, incluindo engenhos de açúcar e lojas do comércio. Embora o protesto tenha se voltado para destruir propriedades e não machucar indivíduos, as forças armadas cubanas reagiram matando afro-cubanos e trabalhadores haitianos indiscriminadamente. (PÉREZ JUNIOR, 1986, p. 537) Um acadêmico afro-cubano recorda:

Eu ainda lembro como eu escutava, olhos bem abertos e enojados, as histórias, sempre sussurradas, sempre ditas como se estivessem revelando segredos indizíveis, sobre os horrores cometidos contra minha família e outros negros durante a guerra racial de 1912. [...] Tive um calafrio na espinha quando ouvi histórias sobre negros sendo caçados dia e noite, e sobre como homens negros eram pendurados pela genitália nos postes de iluminação das praças centrais das pequenas cidades de Cuba. (CASAL, 1979, p. 12)

Um observador direto também notou que o exército "estava decepando cabeças, sem qualquer razão, de todos os negros encontrados fora dos limites da cidade.” (PÉREZ JUNIOR, 1986, p. 537) Houve também um ataque por parte de voluntários civis brancos, que formaram milícias e ofereceram seus serviços "para defender o governo" contra os revoltosos políticos afro-cubanos. (HELG, 1995, p. 203) Desse modo, a guerra das raças de 1912 pode ser considerada um projeto nacional de branqueamento. Pelo menos um analista contemporâneo observou que o massacre foi uma tentativa de os brancos realizarem o sonho de um século: erradicar os negros da ilha de Cuba. (D’OU, 1916) Assim, uma década após a independência, os afro-cubanos estavam em piores 
condições econômicas e sua participação política, pela qual haviam lutado contra os espanhóis, não havia melhorado.

Mesmo os países que foram menos dependentes do trabalho escravo, como o Chile, empreenderam projetos nacionais de branqueamento. Apesar de o Chile ter abolido a escravidão em 1823, o governo abriu uma agência de imigração na Europa em 1882. A agência foi orientada a promover a oferta de concessões de terra para imigrantes europeus, como previsto em uma lei de 1824 que incentivava imigrantes europeus a estabeleceram oficinas em centros urbanos e comunidades em áreas esparsamente povoadas. (GOTT, 2007, p. 283, 286) Muitos dos imigrantes eram originários da Grã-Bretanha, da Suíça e dos estados alemães. Similarmente, o governo paraguaio buscou ativamente imigrantes europeus, os quais poderiam estabelecer suas próprias colônias. Por exemplo, em 1894, 600 indivíduos imigraram da Austrália para o Paraguai para fundar a colônia da "Nova Austrália”, e os alemães chegaram em 1886 para estabelecer a "Nova Alemanha”. (GOTT, 2007, p. 287) Do mesmo modo, no Uruguai, o Estado apoiou ativamente a imigração europeia. (REID ANDREWS, 2010) Uma fonte observa que a onda de imigração europeia se iniciou em 1830 e, em cem anos, mais de um milhão de europeus imigraram para o país. (RAMA, 1970, p. 28-50)

\section{Obstáculos regionais ao projeto de branqueamento pela imigração}

Em muitos países da América Hispânica, os efeitos demográficos do projeto de branqueamento pela imigração europeia foram mitigados por vários fatores. Imigrantes europeus não preferiam países da América Hispânica que eram menos desenvolvidos e mais pobres do que países maiores como Argentina e Brasil. A maior parte dos outros países na América Hispânica e Caribe não tinha recursos para atrair continuamente grandes ondas de imigrantes europeus por meio de subsídios públicos e concessões de terras. $\mathrm{O}$ envolvimento em guerras externas também dificultou a imigração europeia. O Peru, por exemplo, sofreu 10 invasões militares entre 1821 e 1895. (DE LA BARRA, 1959, p. 11-19) Durante o período de guerra, todos os estímulos prometidos aos imigrantes europeus foram obstados pelas limitações fiscais bélicas, as quais negavam privilégios e garantias para estrangeiros. (VÁSQUEZ, 2008, p. 79)

Ademais, em países como Costa Rica, Cuba, República Dominicana, Panamá e Venezuela, onde as indústrias estadunidenses dominavam o mercado e não 
acreditavam nas aspirações da América Hispânica de se tornar branca, quando se depararam com a necessidade de empregar mão de obra barata, optaram pelo recrutamento imediato e massivo da mão de obra das Índias Ocidentais que estava mais acessível. Assim, apesar da disposição legal proibindo imigração não branca para a Venezuela, o setor industrial recebeu entre seis mil e 11 mil trabalhadores sazonais negros das Antilhas anualmente. A resistência da América Hispânica à imigração de trabalhadores das Índias Ocidentais se manifestou na arena política e até em algumas legislações nacionais proibindo a imigração negra, como no caso do Panamá. A lei panamenha de 1926 também exigia que a proporção de trabalhadores nos empreendimentos no país fosse de, no mínimo, 75\% de indivíduos naturais do Panamá, em vez de residentes estrangeiros. (REID ANDREWS, 2004, p. 140) Em Cuba, o governo decretou em 1933 que 50\% de todos os empregados fossem naturais de Cuba e não residentes estrangeiros. (MASFERRER; MESA-LAGO, 1974, p. 362) Na Costa Rica, o empresário e minerador estadunidense, Cooper Keith, que foi contratado em 1871 para a construção de um sistema de linhas férreas, desafiou a disposição legal costa-riquenha proibindo a imigração negra com o propósito de contratar trabalhadores das Índias Ocidentais, os quais ele alegava serem "mais resistentes ao rigor dos trabalhos nos trópicos”. (HARPELLE, 1993, p. 104, 111) Mas devido ao desagrado costa-riquenho por imigrantes negros, o governo se recusou a reconhecê-los como cidadãos e a conceder-lhes direitos sobre as terras que eles cultivaram, uma vez assentados na Costa Rica. (HARPELLE, 1994, p. 98) De fato, aos imigrantes negros na Costa Rica não foram atribuídos os direitos da cidadania até 1949.

$\mathrm{Na}$ ausência de legislação voltada ao branqueamento, um líder nacional chegou a sancionar uma ordem militar para o extermínio direto dos residentes de ascendência africana. Foi o que ocorreu em 1937 sob a ditadura do dominicano Rafael Leónidas Trujillo, na sua campanha contra imigrantes haitianos. Após uma investigação internacional resultar em um acordo de reparação em 1938, Trujillo foi obrigado a pagar 525 mil dólares ao Haiti pelos assassinatos (esse valor corresponde a menos de 30 dólares por cada uma das 20 mil vítimas). (BELL, 2008, p. 41) Ao mesmo tempo em que Trujillo expulsava e exterminava imigrantes haitianos, ele também lançou um programa de colonização agrícola de larga escala para atrair imigrantes europeus. Como resultado, uma colônia judaica se estabeleceu em Sosúa durante a década de 1930.

O desejo hispano-americano por imigrantes europeus só diminuiu quando o influxo de europeus, em alguns países, começou a ser visto como um 
prenúncio das demandas dos movimentos trabalhistas. (BLETZ, 2003, p. 9194, 201) Assim, por exemplo, mesmo na Argentina, terra do projeto hispano-americano mais bem-sucedido de branqueamento, o Congresso em 1902 aprovou a Lei de Residência, autorizando a expulsão ou a negação de entrada de estrangeiros que ameaçassem a ordem pública. (BLETZ, 2003, p. 95-96, 201) Conforme essa lei, qualquer imigrante que participasse em sindicatos poderia ser deportado. Na mesma linha, a Argentina aprovou em 1910 a Lei de Defesa Social, que associou imigrantes com agitação no trabalho e identificou todos os terroristas como estrangeiros. Mas mesmo os imigrantes sendo marginalizados por ameaçarem os interesses econômicos das elites, aqueles assimilados foram integrados à imagem nacional dos argentinos, de uma maneira nunca acessível aos afro-argentinos. (BLETZ, 2003, p. 137-138) Assim, o branqueamento continuou a ser idealizado como o mecanismo para entender a hierarquia racial na Argentina e em toda a América Hispânica.

\section{A mestiçagem como complemento do branqueamento}

A Argentina, o Chile, o Uruguai e o sul do Brasil foram as poucas regiões que conseguiram usar o afluxo de imigrantes europeus para "embranquecer" a aparência das suas populações significativamente e diminuir a proporção de pessoas de visível ascendência africana. Em contraste, outras nações da América Hispânica com maiores proporções de negros e indígenas invocaram com mais veemência o discurso da mestiçagem para manter o privilégio branco. Mestiçagem literalmente se refere ao ato de miscigenação e à produção de uma identidade nacional mestiça, de uma raça mestiça, mas também engloba uma prática discursiva mais ampla de preferir uma hierarquia específica de raça, gênero e classe para a mistura racial. Para a mestiçagem, a noção de que a ancestralidade africana é inferior e necessita ser misturada com raças mais brancas para ser melhorada é central. Assim, com a mestiçagem, a branquitude continua sendo o ideal e o suposto lugar de poder e liderança, mesmo nas supostas "celebrações" nacionais de mistura racial. (SALCEDO-BASTARDO, 1983, p. 118)

O ideário supremacista branco subjacente à mestiçagem fica evidente quando consideramos as especificidades de raça e gênero no discurso de mistura racial. As mulheres brancas da elite foram completamente excluídas de tal idealização. Sua pureza racial e sua condição de classe não estão incluídas na mestiçagem. De fato, elas supostamente serviriam para dar continuidade à elite branca. 
Ao passo que as relações entre mulheres negras e homens brancos eram o foco da mestiçagem e de sua suposta capacidade de diminuir a presença negra no país. Enquanto a intimidade sexual inter-racial foi considerada uma prerrogativa de homens brancos, apenas imigrantes ou homens brancos da classe trabalhadora eram considerados como os maridos ideais das mulheres negras. (GUEVARA, 2005, p. 105-128, 109) O direito cubano do século XIX reflete essa abordagem da mestiçagem orientada pelo gênero ao proibir o casamento entre mulheres brancas e homens negros, enquanto permitia o casamento entre mulheres mestiças e homens brancos. (MILLER, 2004, p. 51) A mestiçagem serviu ao imperativo do branqueamento da América Hispânica do século XIX como a segunda melhor alternativa para promover socialmente aqueles que eram "brancos, mas não tão brancos assim”. (BHABHA, 1984, p. 132)

Assim, depois de tentativas fracassadas de embranquecer efetivamente a população, muitos países da América Hispânica usaram a mistura racial, considerada pelos europeus do século XIX como uma marca emblemática de uma sociedade atrasada, para reinterpretar a mestiçagem como um símbolo de orgulho nacional. (ISFAHANI-HAMMOND, 2004, p. 2) O capítulo 3 discute como o Brasil também empregou a mestiçagem a serviço da promoção de uma identidade nacional de inclusão que justificasse o privilégio racial branco. Os países da América Hispânica tinham uma fonte de referência imediata para a promoção da mestiçagem: as publicações de seus intelectuais famosos, incluindo o abolicionista cubano José Saco (GRAHAM, 1990, p. 39), o revolucionário independentista José Martí (SHNOOKAL; MUÑIZ, 1999, p. 161167), Simón Bolívar, na Venezuela (BIERCK JUNIOR, 1951, p. 110), e José Vasconcelos, no México. (VASCONCELOS, 1925) Enquanto Saco, Martí e Bolívar apresentavam a mestiçagem como uma fonte de unidade nacional frente às batalhas por independência contra a Espanha, Vasconcelos empregou a mestiçagem como uma defesa contra o discurso racial do imperialismo americano que retratava a América Latina como uma região inferior de não brancos. (MILLER, 2004, p. 43) Com a independência da Espanha (obtida entre 1810 e 1898), a mestiçagem também serviu aos governos caribenhos e hispano-americanos que buscavam um discurso inclusivo, com o qual pudessem consolidar o Estado-nação, enquanto mantinham uma hierarquia racial que impediria a integração dos recém-emancipados escravos africanos e seus descendentes, assim como dos muitos soldados negros recrutados para lutar em guerras de independência em nome do igualitarismo. (BLANCHARD, 2002, p. 499-523) Assim, 
por exemplo, em Cuba, José Antonio Saco, o mais eminente intelectual cubano do século XIX, antecipando o desafio que uma cidadania negra emancipada representaria para a supremacia branca, defendeu a imigração europeia e a miscigenação entre homens brancos e mulheres negras porque eles estabeleceriam o grande laço pelo qual a raça africana ascenderia para se misturar com a raça branca. (MARTÍNEZ-ECHAZÁBAL, 1998, p. 29; SACO, 1858, p. 208)

Na República Dominicana, a mestiçagem operou através do mito da vibrante ancestralidade indígena, com o propósito de não apenas afastar o país de uma identidade negra, mas também de diferenciá-lo de seu vizinho negro, o Haiti. Isso foi feito aumentando o papel dos ancestrais indígenas na República Dominicana para oferecer uma justificativa genética para a pele escura (apesar do fato de a grande maioria da população indígena ter sido morta nos 50 anos após a chegada de Colombo, em 1492). A publicação em 1882 do livro Enriquillo representou uma maior aproximação da identidade nacional com o passado indígena, supostamente mais importante que a influência genética da grande população africana. (DE JESÚS GALVÁN, 1882) A narrativa histórica descreve um líder indígena que chefia uma insurreição em 1519 contra os colonizadores espanhóis e negocia pacificamente um governo independente em troca de africanos fugidos. Como consequência da promoção do ancestral indígena dominicano, o termo "índio" se tornou o preferido para identificar uma pessoa mestiça, ainda que no século XIX poucas pessoas, se alguma, seriam capazes de encontrar uma ligação com um ancestral indígena verdadeiro. (FENNEMA; LOWENTHAL, 1987, p. 28) O termo "índio" é propositalmente ambíguo e corresponde ao que outros países hispano-americanos denominam "mulato", porém invoca um passado indígena inventado para elidir o significado dos ancestrais africanos desprezados. (HOWARD, 2001, p. 41) O índio se tornou um mito institucionalizado durante a ditadura de Trujillo (1931-1961), quando todos os documentos oficiais reificaram a mítica figura do índio. De fato, Trujillo ordenou que livros de história fossem reescritos para apagar o reconhecimento à ancestralidade africana dos dominicanos. (SIMMONS, 2009, p. 29)

Todavia, ao contrário da República Dominicana, alguns países na América Hispânica tinham e continuam a ter uma população indígena considerável. Nesses países, em que havia uma menor proporção de brancos e um maior número de pessoas indígenas de verdade, a mestiçagem também foi usada como resultado da mistura racial de brancos com aqueles que tinham ancestralidade 
indígena, assim dando origem ao mestiço, de forma a também extirpar o passado africano do imaginário nacional. O antropólogo Jean Muteba Rahier se refere ao fenômeno como um processo nacional de "mestiçagem monocultural”. (MUTEBA RAHIER, 2008, p. 148-182) Por exemplo, no México, a elevação do mestiço indígena que assimilou os valores culturais europeus à categoria de símbolo nacional foi feita paralelamente ao rebaixamento da negritude. (ROSENBLAT, 1954, p. 32-35) Como mencionado antes neste capítulo, o intelectual mexicano José Vasconcelos, figura-chave para a consolidação da mestiçagem, promoveu a ideia de uma "raça cósmica" miscigenada que permitiria a mestiços, com ancestralidade branca e indígena, a modernizar a nação, enquanto os "estoques inferiores" de negros sumiriam da população. Com a exclusão dos negros da conceitualização mexicana de mestiçagem, não é surpreendente o fato de que, no estudo de Bobby Vaughn sobre a identidade afro-mexicana contemporânea, ele "não encontrou, entre os negros, evidência da visão dominante no México de que a herança indígena é fundamental para sua própria herança”. (VAUGHN, 2005, p. 117-136, 123) Do mesmo modo, a mestiçagem operou para marginalizar a negritude e promover a assimilação dos indígenas em países como o Equador (WHITTEN JUNIOR, 1981, p. 45-94), a Guatemala (NÚÑEZ, 2006, p. 4-7) e Honduras (EURAQUE, 1998) (com o uso do termo ambíguo "ladino", para distinguir os não brancos, assimilados com o capital social, dos indígenas e negros excluídos do imaginário nacional).

Considerando que, assim como a mestiçagem, termos usados para designar aspectos raciais como "mulato" (em castelhano, mulatto) e "mestiço" (em castelhano, mestizo) são usados para identificar as pessoas percebidas como racialmente misturadas. Os termos em si podem ser vistos como ferramentas de branqueamento na medida em que o número de pessoas com ascendência africana é embranquecido com a elevação da categoria racial de "negro" para "mulato" ou "mestiço". (ROSA, 1996, p. 285) Assim, o aspecto branqueador da mestiçagem está particularmente evidente no emprego dos termos por parte dos governos em censos que, com frequência, omitem totalmente dados raciais.

\section{O censo como instrumento de branqueamento e mestiçagem}

As análises históricas feitas sobre os censos e outros dados demográficos na Argentina da primeira parte do século XIX sugerem de forma bastante 
persuasiva que os recenseadores reclassificaram grande parte da população afro-argentina que, em vez de ser incluída na categoria racial de "puro" negro ou moreno, em castelhano, era incluída nas categorias de "pardo" (pessoa mestiça também conhecida como mulatto) e "branco". (REID ANDREWS, 1980, p. 64-92) Devido à velocidade com que os números na categoria "moreno" diminuíram ao mesmo tempo em que os números da categoria "pardo" aumentaram - a uma velocidade muito maior que as possibilidades biológicas de geração de descendentes mestiços -, aparentemente, muitos morenos foram simplesmente reclassificados como pardos. À época, os recenseadores selecionavam a categoria racial do entrevistado baseados em uma inspeção visual em vez de o indivíduo se autoclassificar. (GOYER; DOMSCHKE, 1983, p. 41-49) A reclassificação estratégica de morenos para pardos, e de pardos para brancos, serviu para embranquecer a representação estatística da nação. Enquanto negros e pardos somados representavam, pelo menos, $25 \%$ da população nacional argentina em 1810, 1822 e 1838, em 1887, eles representavam apenas $1,8 \%$ da população. (DOWNES, 2006) Uma vez que a Argentina se comprometeu constitucionalmente a embranquecer o país por meio do afluxo de imigrantes europeus, os formulários do censo deixaram de usar a categoria racial ambígua de pardo, e todas as pessoas de ascendência africana passaram a ser agrupadas na categoria "de cor". O ano de 1887 foi a última vez em que o censo argentino incluiu a questão racial em um formulário até o censo de 2010. (DOWNES, 2006)

$\mathrm{Na}$ mesma linha, o vizinho Uruguai, em 1852, deixou de adotar a questão sobre categoria racial em seu censo, só tendo voltado a registrá-la a partir de 1996. (BUCHELI; CABELA, 2006, p. 2) Na Colômbia, o censo deixou de levantar informações sobre categoria racial em 1843, só tendo voltado a fazê-lo a partir de 1993. (BODNAR, 2005, p. 14) Na Costa Rica, desde o princípio do censo decenal em 1861, uma questão relacionada à raça foi incluída apenas nos censos dos anos de 1927, 1950 e, mais recentemente, no censo de 2000. (ALLEN, 2000; SCHKOLINK; DEL POPOLO, 2005) Uma mudança atual em direção à reinclusão da categoria "raça" nos censos em alguns países da América Hispânica é um resultado do lobby de organizações sociais do movimento social negro e de organizações internacionais que os apoiam. Com a classificação racial do censo, dados socioeconômicos podem ser desagregados para que se demonstre estatisticamente as disparidades raciais existentes. 
Apesar disso, as ações estratégicas de embranquecimento promovidas pelos recenseadores oficiais têm sido especialmente bem documentadas no caso de Porto Rico. Embora Porto Rico seja um território do governo estadunidense desde 1898, suas práticas culturais e política racial derivam mais diretamente do legado histórico e colonial espanhol de branqueamento e mestiçagem. (TORRES, 1998, p. 285-306) Por essa razão, suas práticas de embranquecimento a partir do censo explicam muito sobre a operação latino-americana de branqueamento e mestiçagem. A recente divulgação de estudos feitos com pequenas amostras dos censos de 1910 a 1920 tornou possível, pela primeira vez, documentar empiricamente o papel do censo no embranquecimento estatístico da população. A análise dos dados indica que um aumento dramático de 7,5\% na população branca entre 1910 e 1920 (um aumento maior que o dobro do aumento de qualquer outra década no século XX) não poderia ser atribuído somente ao aumento ligado a fatores naturais como fertilidade e migração. Pelo contrário, demógrafos têm demonstrado que o embranquecimento da população porto-riquenha foi quase inteiramente devido à reclassificação racial pelos recenseadores.

Assim, se a miscigenação tivesse sido a principal fonte de embranquecimento de Porto Rico nesse período, seria esperado que os resultados do censo de 1920 mostrassem um declínio na proporção da população classificada como negra, juntamente com um aumento na proporção da população classificada como mulata. Contudo, observa-se um declínio em ambos grupos da população, juntamente com um drástico aumento na proporção de brancos. (LOVEMAN; MUÑIZ, 2007, p. 915-939)

A partir de uma mudança cultural decorrente de como a branquitude era definida socialmente, os recenseadores em 1920 estavam 60\% mais propensos a classificar uma criança de pais de raças diferentes como branca que os recenseadores de 1910, apesar de a categoria racial mista, a de mulato, ainda constar como uma das categorias oficiais do censo. Após o censo de 1920, os seguintes continuaram a trajetória de embranquecimento até a classificação racial deixar de ser feita em 1952 (e ser retomada apenas no censo de 2000).

O controle estadunidense sobre Porto Rico depois da Guerra Hispano-Americana, de 1898, ironicamente possibilitou uma demonstração mais clara da operação hispano-americana e caribenha de branqueamento. Apesar de o Departamento de Recenseamento dos Estados Unidos organizar a contagem 
dos censos porto-riquenhos desde 1899, a preferência do governo estadunidense por precisão no que diz respeito às categorias raciais era subvertida pela implementação dos recenseadores porto-riquenhos. Como apenas a partir do censo de 2000 os porto-riquenhos passaram a se autodeclarar em termos de raça, o papel do recenseador na classificação racial da população porto-riquenha foi significativo. Historicamente, o Departamento de Recenseamento dos Estados Unidos encarregou um agente estadunidense para dirigir o recenseamento porto-riquenho, assim como para editar os resultados de modo a tornar o censo "racialmente preciso". Os agentes especiais foram selecionados entre as "melhores classes" porto-riquenhas para ajudar na edição dos resultados. (SKINNER, 1910) Em 1920, a maioria esmagadora (88\% dos 16.965 formulários) das reclassificações de indivíduos se deu da categoria "branco" para a categoria "mulato" (13.225) e um número muito menor para a categoria "negro" (1.665). (LOVEMAN; MUÑIZ, 2007, p. 923) Em resumo, a edição dos resultados controlada pelos Estados Unidos com uma abordagem mais restritiva em relação aos limites de branquitude enfatiza a maneira pela qual os formulários não editados refletem a operação de branqueamento porto-riquenha. Em outras palavras, os recenseadores porto-riquenhos reproduziram a ideologia de branqueamento e mestiçagem, a qual Porto Rico compartilhava com a América Hispânica, por meio da crescente classificação de porto-riquenhos mestiços de pele mais clara como brancos ao longo dos censos. De fato, o próprio Departamento de Recenseamento dos Estados Unidos admitiu o papel do branqueamento quando informou, em 1938, que o declínio da população porto-riquenha não branca "foi sem dúvida resultado da gradual mudança no conceito de classificação racial empregado pelos recenseadores” em Porto Rico. (ESTADOS UNIDOS, 1938, p. 17) Depois disso, ao ganhar maior autonomia política, o governo local de Porto Rico conseguiu, por meio de lobby, eliminar o campo sobre raça dos questionários do censo sob a justificativa de que a mistura racial porto-riquenha tornava aquela questão sem importância. Assim como o resto da América Hispânica, que relutou em aceitar as implicações da inferioridade racial afirmada pela eugenia do século XIX, Porto Rico recorreu ao branqueamento e mestiçagem como tropos da modernização e da unidade regional nos anos que sucederam a Guerra Hispano-Americana, com o subsequente controle do território pelos EUA e a atribuição, em 1917, da cidadania estadunidense para os porto-riquenhos na ilha. (TORRES, 1998, p. 285-306) Em 2000, o censo reincorporou a questão sobre raça e descobriu que $80,5 \%$ da população 
se autodeclarava branca, percentual superior à população autodeclarada branca nos Estados Unidos em 5,4\%, fato que fortemente sugere a continuidade da importância do ideal de branqueamento e mestiçagem. (GODREAU; LLORÉNS; VARGAS-RAMOS, 2010, p. 11-12) No censo de 2010, 75,1\% dos entrevistados porto-riquenhos selecionaram novamente apenas a categoria "branco", ao passo que apenas $3,2 \%$ selecionaram mais de uma categoria racial, 7,8\% selecionaram "alguma outra raça" e 12,3\% selecionaram "negro".

Embora o caso porto-riquenho certamente tenha sido extremo na sua articulação do branqueamento a partir do censo, outros países da América Hispânica e do Caribe também usaram o censo para dar suporte às suas ideologias raciais. Por exemplo, a opção generalizada de omitir informações raciais dos censos foi uma estratégia comum de promoção do branqueamento e, particularmente, da mestiçagem. Importante notar que mesmo enquanto muitos países hispano-americanos omitiram dos censos as questões sobre raça ou cor, esses países frequentemente incluíam questões sobre ascendência indígena, como foram os casos do Chile (MANDIVER, 1949, p. 138-146), México (AUGUSTINE-ADAMS, 1954, p. 331-342; GOYER; DOMSCHKE, 1983, p. 246), Panamá (AVILÉS BÓSQUEZ, 2000) e Venezuela. (MASON MANDIVER, 1949, p. 145) Assim, a eliminação de informações raciais dos formulários dos censos não pode ser vista simplesmente como uma crença nacional na não importância da cor, mas sim como uma recusa estratégica de reconhecer a presença de negros nos países da região. Isso é particularmente evidente no caso da Guatemala cujo censo de 1940 incluiu a categoria racial "negro". Porém, em 1950 o país omitiu essa categoria racial, mas manteve a categoria de indígena ou não indígena, negando, dessa forma, qualquer reconhecimento estatístico à população afro-guatemalteca. (AGUIRRE, 2000) De fato, um estudo histórico indica que a não identificação da população afro-guatemalteca começou na época colonial, quando um grande número de guatemaltecos de ascendência africana foi contabilizado como população mestiça de ancestralidade indígena ou branca. (LUTZ, 1994)

O México também é em um caso interessante de país em que, após a conquista da independência da Espanha em 1821, proibiu legalmente a classificação de pessoas por critério de raça em todos os documentos oficiais. A Assembleia Constituinte Soberana do México aprovou o Plano de Iguala que instituiu a probição. (GONZÁLEZ NAVARRO, 1970, p. 145-169) Todavia, a proibição legal não teve influência em vários órgãos governamentais 
que continuaram a diferenciar a população mexicana por critérios de raça (LOVELL BANKS, 2006, p. 199-234) e consideravam a população indígena mais inteligente que os descendentes de africanos. Como a condessa Paula Kolonitz, membro da elite política em 1864, declarou: "Os índios são muito mais inteligentes que os negros e seu caráter possui uma constituição mais nobre”. (CORREA, 2007, p. 80-95)

De fato, mesmo a contagem da população nacional imediatamente posterior à Revolução Mexicana (1910-1920), em 1921, continha classificações raciais: "indígena”, "indígena com branca” e "branca”. (AUGUSTINE-ADAMS, 2009, p. 124) Somente a categoria "negro com branco" foi omitida. A classificação racial era importante, mas a negritude foi considerada irrelevante para a identidade nacional do país. Apesar disso, os governos de alguns estados conduziram seus próprios recenseamentos que incluíam classificações raciais, tal qual Oaxaca em 1890, que incluiu as categorias "indígena”, "negro", "mestiço" e "branco". (CORREA, 2007, p. 95) No censo de 1890 do estado de Oaxaca, os afro-mexicanos com menos de 15 anos representavam 20\% da população. É muito improvável que toda essa população de $20 \%$ de jovens de Oaxaca tenha se extinguido antes do censo de 1920. Em outras palavras, os afro-mexicanos ainda estavam presentes, apesar da falta de disposição de incluí-los na contagem da população.

A interrupção da coleta de informações raciais nos formulários dos censos decenais na América Hispânica foi frequentemente acompanhada por um forte discurso governamental de mestiçagem. Por exemplo, quando o governo mexicano, em definitivo, omitiu oficialmente todas as classificações raciais no censo nacional de 1930 , a atitude foi tomada em meio a grande alarde (contudo, a contagem de indígenas era feita indiretamente por meio de questões sobre a língua falada, o que continuou nos censos entre 1940-1970). O Departamento Nacional de Estatísticas do México, em 1930, declarou que classificações raciais no censo não eram mais necessárias porque a população estava tão misturada racialmente e a estratificação social era uma questão de classe econômica, não de identidade racial. (AUGUSTINE-ADAMS, 2009, p. 125) A maneira pela qual o governo mexicano abertamente promoveu o censo como ferramenta de construção da nação também é particularmente digna de nota. Os cartazes disseminados pelo departamento de recenseamento como preparação para o censo de 1930 declaravam audaciosamente: "Responda ao censo, construa um país. Façamos as duas coisas juntas" e também "Responder ao censo fará um país”. (AUGUSTINE-ADAMS, 2009, 
p. 114) Com essas palavras, o departamento de recenseamento mexicano ironicamente representou a aspiração da América Hispânica de criar uma nação moderna por meio do recenseamento que refletiria uma cidadania nacional idealizada e distante da negritude.

Em suma, depois da emancipação dos escravos, a América Hispânica enquanto região buscou embranquecer sua população como veículo de modernização. Alguns países, como a Argentina, fizeram uso exitoso das leis de imigração e subsídios governamentais para embranquecer a população com o influxo de imigração europeia. Outros países da América Hispânica, menos bem-sucedidos em embranquecer suas populações por meio da imigração europeia, valeram-se da apresentação estratégica de censos oficiais para ocultar a presença demográfica de populações de ascendência africana. Esses esforços foram acompanhados de diversas tentativas de promoção da mestiçagem. Com efeito, as leis formais de imigração e as leis não escritas refletidas nas práticas de contagem dos censos e nas campanhas nacionais de identidade mestiça pretenderam marginalizar e limitar a cidadania plena dos afrodescendentes. Assim como as leis Jim Crow de segregação nos Estados Unidos, o branqueamento espanhol e as campanhas de mestiçagem, de modo semelhante, "mantiveram os negros em seus lugares" na ausência da escravidão. (SMITH, 1966, p. 379-387, 380)

A história da América Hispânica, baseada no uso racializado do direito legislado no contexto da imigração, desmente a narrativa de inocência racial que durante tanto tempo tem obstruído os esforços contemporâneos de igualdade racial. Similarmente, o envolvimento do Estado na política de recenseamento voltada ao branqueamento pode ser considerado um direito costumeiro de regulação racial. Na medida em que o Estado tinha uma prática costumeira de empregar o censo para embranquecer a população e, com isso, marginalizar a cidadania dos afrodescendentes, as políticas de Estado consolidaram o direito costumeiro de regulação racial. Não obstante, o Brasil se destaca por ser o país onde o desenvolvimento de um direito costumeiro de regulação racial foi mais amplo e mais documentado que no restante da América Latina. Por essa razão, o direito costumeiro de regulação racial brasileiro merece um exame mais detalhado no próximo capítulo. 


\section{A versão brasileira da legislação Jim Crow: o projeto de embranquecimento do direito de imigração e o direito costumeiro de segregação racial: um estudo de caso}

O Brasil foi o último país das Américas a emancipar seus escravos em 1888. Apesar da abolição da escravidão, o Brasil compartilhou do desinteresse latino-americano em integrar plenamente e conceder direitos subjetivos de cidadania aos seus habitantes negros. Esse foi um assunto que inquietou as elites brasileiras, levando-se em conta o significativo número de escravos que tinha sido importado para o país. De fato, mais de $90 \%$ dos aproximadamente 10 milhões de escravizados africanos trazidos para as Américas foram levados para a América Latina e para o Caribe, ao passo que apenas 4,6\% foram levados para os Estados Unidos. (MINTZ, 1974) Um historiador estima que o número total de escravos africanos importados para o Brasil foi de 3,6 milhões. (TAUNAY, 2001) Em contraste, historiadores estadunidenses estimam que apenas 500 mil escravos africanos foram importados para os Estados Unidos e América do Norte Britânica. (THOMAS, 1997, p. 500) A resposta brasileira para o medo gerado por uma população negra recém-liberta foi similar a do resto da América Latina: uma tentativa de embranquecer a população.

No Brasil, a filosofia do embranquecimento, chamada de "branqueamento”, foi diretamente comparável à filosofia de blanqueamiento da América 
Hispânica. Assim como o blanqueamiento na América Hispânica, o branqueamento no Brasil foi uma ideologia e um conjunto de práticas de embranquecimento da população brasileira e de suposta modernização da nação. Os esforços para embranquecer a população foram tão amplos na região que um acadêmico descreveu a América Latina como tendo uma "cultura de colono branco" que até hoje exerce influência, em oposição ao reconhecimento e inclusão integral dos não brancos. (GOTT, 2007, p. 269-289) O Brasil se destaca entre os países latino-americanos, tendo o mais amplo aparato legislativo para regular restritivamente a questão da raça no período pós-abolição da escravidão, e serve de caso de estudo útil por oferecer mais detalhes sobre o desenvolvimento do direito costumeiro de regulação racial.

\section{A regulação racial: 0 direito de imigração}

O primeiro passo na campanha nacional de embranquecimento foi arquitetar legislações de imigração restritivas para, em primeiro lugar, encorajar a imigração europeia e, em segundo lugar, proibir ou fortemente desestimular a imigração de pessoas de ascendência africana, asiática ou indígena. Ainda em 1850, com a crescente pressão internacional para abandonar o tráfico de escravos e abolir completamente a escravidão, o poder legislativo brasileiro tomou medidas decisivas para estimular a imigração europeia. (BUTLER, 1998, p. 26-27) Uma lei aprovada naquele ano ofereceu generosas concessões de terras para imigrantes com o fim de encorajar a vinda de um maior número de europeus. (PRUDENTE, 1989, p. 129-131) A mesma lei negava títulos de propriedade de terra para quilombolas. O governo da província de São Paulo financiou generosamente a Sociedade Promotora de Imigração. (HOLLOWAY, 1977, p. 163)

Depois da emancipação dos escravos em 1888 e da dissolução do Império brasileiro em 1889, a preferência legal por imigrantes brancos se tornaria ainda mais explícita, pois às elites desagradava a visão de descendentes de africanos como trabalhadores remunerados. (AZEVEDO, 1987, p. 252) As atas das reuniões oficiais de donos de plantações, os quais já esperavam pelo fim da escravidão, registraram a preferência por imigrantes brancos em vez da "indolência" da população nativa, de "raça decrépita", que trabalhava em servidão. (TRABALHOS, 1878, p. 155-159) A preferência por imigrantes europeus como racialmente motivada se torna clara ao se observar que os europeus recrutados não 
eram trabalhadores especializados, muitos eram camponeses analfabetos. (DOMINGUES, 2004, p. 89-91) Além do mais, no período posterior à abolição, quando imigrantes europeus estavam sendo procurados, os postos de trabalho assalariado disponíveis eram para trabalhadores pouco qualificados, sem educação ou treinamento profissional, que poderiam ter sido facilmente preenchidos pelos brasileiros recém-emancipados, se os mesmos não fossem vistos como racialmente inadequados para o trabalho pago. (KOWARICK, 1987, p. 118) Anúncios nos classificados dos periódicos explicitamente declaravam: "Preferimos brancos”. (DOMINGUES, 2004, p. 109-110) Essas atitudes racializadas sobre a capacidade de trabalhar como assalariado se refletiram nas assembleias legislativas regionais. $\mathrm{Na}$ assembleia legislativa paulista de 1888, a preferência por trabalhadores estrangeiros brancos foi discutida juntamente com a proposta de conceder terras para estimular a imigração. (SÃO PAULO, 1888, p. 32)

Consequentemente, um dos primeiros atos normativos da nova república foi o Decreto de Imigração ${ }^{0} 528$, promulgado em 28 de junho de 1890, pelo presidente provisório Manoel Deodoro da Fonseca. (PRUDENTE, 1989, p. 151-152) O decreto excluía todos os membros de populações indígenas da Ásia e da África da imigração para o Brasil. Isso ocorreu em um período em que a imigração em geral estava em seu auge e imigrantes de outros continentes, como da Europa, tinham permissão de entrada sem pagamento de taxa. Em 1921, o Congresso Brasileiro aprovou uma lei similar, na qual proibiu especificamente imigrantes negros de entrarem no Brasil. (BRASIL, 1921) Quando os negros tentavam imigrar para o país, eles simplesmente tinham seus vistos negados. (MEADE, 1996, p. 31) Tal fato precedeu a lei estadunidense de imigração por cotas segundo a origem nacional, de 1924, a qual explicitamente regulou a imigração de acordo com critérios de raça e origem étnica. Entretanto, uma das provisões instituídas foi relaxada dois anos depois, quando uma lei aprovada em 1892 permitiu a entrada de imigrantes chineses e japoneses. (PRUDENTE, 1989, p. 153-154) As grandes ondas de imigração no Brasil coincidiram com a abolição da escravidão em 1888, e a imigração europeia era uma política nacional no final do século XIX, tendo o Brasil um número de imigrantes inferior apenas ao da Argentina. (BLETZ, 2003, p. 22-23, 30) Ressalta-se que, em 1889, o Brasil aprovou uma lei para garantir a naturalização automática aos imigrantes de origem europeia. (BLETZ, 2003)

Além do mais, o governo usou dinheiro público, para encorajar a imigração europeia, no pagamento dos custos com transporte. O governo brasileiro 
arcou com o transporte de europeus para o Brasil, de 1851 a 1909, e a província de São Paulo (depois, estado) fez o mesmo, de 1881 a 1927. (BLETZ, 2003, p. 157-158) O direito administrativo paulista também oferecia subvenções para moradia, alimentação e serviços de saúde hospitalares (SÃO PAULO, 1887, art. 17, p. 7), além de oferecer auxílio financeiro em espécie, que variava conforme a idade do imigrante europeu. (SÃO PAULO, 1887) As despesas com imigração financiadas pelo estado de São Paulo também incluíam atividades de lobby pró-imigração nos países europeus de origem, bem como a cessão de ferramentas agrícolas e a dispensa de serviço militar para os filhos dos imigrantes. (DOMINGUES, 2004, p. 69) Em 1888, apenas alguns meses antes da abolição total da escravidão, a Assembleia Provincial de São Paulo autorizou o governo a alocar a grande variedade de subsídios para a imigração a um mínimo de cem mil imigrantes. (LOBO, 1924, p. 219) A alocação de recursos do governo para o projeto de branqueamento por meio da imigração europeia foi tão expressivo que em 1895 os subsídios para a imigração representavam 14,5\% do orçamento anual de São Paulo, 10\% do orçamento de 1896 e 10,8\% do orçamento de 1901. (SÃO PAULO, 1941, p. 6-22)

Enquanto as comportas eram abertas para imigrantes europeus, a proibição da entrada de imigrantes africanos foi interpretada extensivamente, a ponto de excluir turistas estadunidenses de ascendência africana que nunca haviam pisado na África e nem sequer eram cidadãos de países do continente africano. Além do mais, o governo brasileiro continuou a desprezar cidadãos estadunidenses de origem africana a despeito do flagrante descumprimento do Tratado de Paz, Amizade, Navegação e Comércio, de 1828, entre Brasil e Estados Unidos. Esse tratado declarava que "os cidadãos e súditos de ambos os países podem viajar de um país a outro, e têm direito de residir e fazer negócios [...]. Haverá uma paz e amizade perfeita, estável e inviolável entre [os Estados Unidos e o Brasil] em todas suas possessões e territórios”. (LESSER, 1994, p. 23-44)

A restrição racial no direito de imigração brasileiro continuou com o governo de Getúlio Vargas (1930-1945). Em 1934, a Nova Constituição efetivamente reservaria a possibilidade de imigração a brancos. (PRUDENTE, 1989, p. 155156) Isso foi feito estabelecendo um teto anual de $2 \%$ do número de imigrantes de acordo com a origem nacional daqueles que haviam chegado ao Brasil nos últimos 50 anos. Considerando o período, a imigração de africanos não era possível no Brasil. O dispositivo constitucional, estabelecendo a cota anual de $2 \%$, na prática, proibiu qualquer imigração africana sem ter que fazer menção à raça em 
seu texto. (BRASIL, 1934, art. 121, par. 6) A Constituição brasileira também proibiu colônias de negros ou asiáticos independentemente de sua origem nacional, por meio da proibição da concentração de imigrantes em qualquer parte do país quando houvesse possibilidade de conflito com o direito de regular a seleção de imigrantes e sua assimilação. (BRASIL, 1934, art. 121, par. 7) Essa medida foi presumivelmente elaborada para limitar a imigração de outros países latino-americanos. (PRUDENTE, 1989, p. 155-156) Provisões constitucionais, elaboradas para permitir que o governo impedisse imigrantes não brancos de entrar no país, foram adotadas na Constituição de 1946 e em um decreto de 1969 do governo militar. (BRASIL, 1946, art. 162)

O projeto de imigração para fins de branqueamento foi tão bem-sucedido que, em menos de um século de imigração europeia subsidiada, o Brasil importou mais trabalhadores brancos livres do que escravos negros em três séculos de tráfico de escravos (4.793.981 imigrantes chegaram entre 1851 e 1937, em comparação com os 3,6 milhões de escravos trazidos à força). (SANTOS; HALLEWELL, 2002, p. 70) Em São Paulo, onde a imigração europeia foi a mais intensa, a população de descendentes de africanos (pardos e pretos contados juntamente) diminuiu de $47 \%$ em 1811 e 1836 para $16 \%$ em 1928. (LOWRIE, 1938, p. 12)

Com uma política de imigração explicitamente baseada em raça, legisladores brasileiros e atores da elite manifestaram expressamente o desejo de usar a imigração para erradicar os negros. Assim como os projetos de branqueamento da América Hispânica, a imigração branca brasileira se fundava em um discurso eugenista que reforçava as crenças brasileiras preexistentes sobre a inferioridade de africanos e sua futura extinção definitiva. (SANTOS; HALLEWELL, 2002, p. 75) Por exemplo, em 1879, o parlamentar Joaquim Nabuco afirmou: "O negro e o branco, vivendo misturados socialmente durante séculos, o sangue preto naturalmente tenderá a ser eliminado no sangue branco, ou a desaparecer, cedendo essa raça o campo a outra mais preparada para a luta da vida". (NABUCO, 1983, p. 182)

À medida que aumentou o número de imigrantes europeus, também cresceu o apoio público de intelectuais à eugenia. Em 1912, um intelectual da elite, João Batista Lacerda, que estava presente no primeiro Congresso Universal das Raças, de 1911, previu que, em 2012, a população brasileira seria composta por $80 \%$ de brancos, $3 \%$ de mestiços e $17 \%$ de indígenas; não haveria negros. (SKIDMORE, 1974, p. 67) A previsão de Lacerda foi, aparentemente, apoiada 
por uma análise oficial do censo brasileiro. Apesar de a questão de raça/cor ter sido omitida dos censos de 1900 e 1920, o renomado teórico social Oliveira Vianna escreveu um artigo oficial, em 1920, anunciando que já havia ocorrido uma rápida diminuição do "coeficiente de sangue inferior" no patrimônio genético brasileiro. (VIANNA, 1922) Depois disso, o censo e outros instrumentos públicos com dados estatísticos seriam o veículo para branquear a imagem nacional. $\mathrm{O}$ embranquecimento simbólico da população foi facilitado por um decreto de 14 de dezembro de 1890 do ministro da Fazenda, Rui Barbosa, que ordenava a destruição de todos os documentos do Ministério da Fazenda relacionados à escravidão (escrituras, diários de bordo, documentos religiosos). (LACOMBE, 1988) O Congresso Nacional ratificou o decreto de Barbosa em 20 de dezembro de 1890. Como abolicionista, o ministro Barbosa queria remover a "mancha negra" do passado escravista brasileiro. (BRASIL, 1891) Contudo, o decreto também dificultou a investigação das origens africanas de muitos brasileiros "brancos".

Dada a interpretação do direito de imigração e da política imigratória altamente baseada em raça, como pode ser explicado o grande número de imigrantes japoneses que chegaram ao Brasil a partir de 1908? Quase 250 mil japoneses se estabeleceram no Brasil em um período de 60 anos, entre 1908 e 1968. (MAKABE, 1999, p. 702-723) A população é a maior comunidade japonesa fora do Japão, com exceção da Manchúria. (MASTERSON; FUNADA-CLASSEN, 2004, p. 73) Com o estabelecimento dessa população, principalmente na região de São Paulo, sua presença foi facilmente percebida e não estava de acordo com o discurso eugenista predominante na época. Como essa mudança populacional foi possível?

A conjunção da demanda da economia cafeeira por mão de obra barata e da crise socioeconômica japonesa da década de 1920, juntamente com a proibição estadunidense de 1907 ao ingresso de imigrantes japoneses naquele país, influenciou a vinda de grandes números de japoneses imigrantes. (ESTADOS UNIDOS, 1907, 1917, 1924) Com a proibição de ingresso nos Estados Unidos a partir de 1907, o governo japonês procurou destinos alternativos para seus trabalhadores agrícolas, como a Argentina, o Peru e o México, e também o Brasil. (MASTERSON; FUNADA-CLASSEN, 2004, p. 5) O governo japonês arcou com o transporte e outras despesas dos imigrantes, além de negociar empregos em plantações e habitação para as famílias. As regras brasileiras exigiam que pelo menos três agricultores fisicamente capazes em uma família 
migrassem de uma vez para garantir o início imediato da produção agrícola. (MAKABE, 1999, p. 721)

$\mathrm{O}$ interesse da economia cafeeira no trabalho de agricultores japoneses foi tão grande que alguns caracterizaram os imigrantes como culturalmente brancos devido à sua superioridade em relação aos afro-brasileiros "nativos”. Por exemplo, em 1925, o congressista Oliveira Botelho afirmou:

Os turcos e sírios de pele branca e boa aparência física, imigrantes voluntários, preocupam-se apenas com o comércio e não saem das cidades. O clamor agrícola por braços fortes nunca nos perdoará se, por pretextos fúteis, nós impedirmos esse desenvolvimento. [...] Se os 30 milhões de brasileiros produzirem a mesma proporção de $30 \mathrm{mil}$ trabalhadores japoneses aqui, o Brasil será o país mais rico no mundo. (BUTLER, 1998, p. 37)

Mesmo com as limitações constitucionais estabelecidas por Vargas sobre a imigração de não brancos, em 1934, um deputado federal afirmou que "os colonos japoneses são ainda mais brancos que os portugueses (com sua contribuição para a branquitude do crescimento econômico e produção doméstica)”. (LESSER, 2000, p. 1-12) Tais perspectivas foram corroboradas pelo investimento dos próprios imigrantes japoneses na promoção midiática da sua branquitude. Jornais, revistas e livros regularmente publicavam fotografias de crianças com "cara de brasileiro”, eram filhos de pais japoneses e brasileiros brancos. (LESSER, 1999, p. 105) Essas fotografias parecem sugerir que os japoneses eram os candidatos ideais para a mestiçagem capaz de resultar em branquitude mais imediatamente. Os japoneses não foram literalmente considerados brancos, mas os proprietários de terra que apoiaram sua entrada certamente os consideravam superiores aos trabalhadores afro-brasileiros. (LESSER, 1994, p. 23-44)

Sem dúvida, durante o período da Segunda Guerra Mundial, as vozes daqueles que fizeram oposição à imigração não branca dos japoneses conseguiram ter mais espaço público. Apesar disso, o Brasil não implementou um plano de evacuação em massa ou reassentamento de seus residentes japoneses, como fizeram os Estados Unidos durante a guerra. Os brasileiros de ascendência japonesa puderam continuar suas atividades laborais e negócios sem interrupções porque, àquela altura, grande parte do país dependia de sua produção agrícola. (MAKABE, 1999, p. 709) Em vez de isolar toda a comunidade japonesa, foi lançada uma campanha para "abrasileirar” os residentes japoneses. Os jornais e as escolas em 
línguas estrangeiras foram proibidos, leis proibiram o uso da língua japonesa em espaços públicos e nomes próprios japoneses foram obrigados a serem cristianizados. (AUGELLI, 1958, p. 3-19) Em resumo, enquanto um complexo conjunto de circunstâncias influenciou a migração em larga escala de japoneses para o Brasil, sua presença nunca ameaçou a valorização nacional da branquitude. Em 1975, um grande banco brasileiro lançou uma campanha publicitária com a seguinte frase: "Precisamos de mais brasileiros como os japoneses". (LESSER, 2000, p. 11) O anúncio foi bem recebido e continuou a circular por mais de 25 anos.

\section{Segregação do mercado de trabalho}

Se os negros não foram completamente erradicados da população brasileira, a política de branqueamento foi bem-sucedida na medida em que os escravos recém-libertos e seus descendentes foram propositalmente preteridos no mercado de trabalho em razão da importação de imigrantes europeus. Nenhum suporte ou garantia social de qualquer tipo foi oferecido para ajudar os antigos escravos a ingressarem no mercado de trabalho depois de sua libertação. Embora seja verdade que o estado da Bahia aprovou uma lei de distribuição de terras não baseada em critérios raciais em 1897, a qual poderia teoricamente possibilitar afro-brasileiros recém-libertados e outros a terem acesso às escrituras de pequenas propriedades, também é verdade que os escravos libertos encontraram muitos obstáculos que os impediram de obter esses títulos em grande quantidade. (MAHONY, 1998, p. 90-116)

Além do mais, os afro-brasileiros foram sistematicamente excluídos do mercado de trabalho. Por exemplo, sabe-se que depois da emancipação as forças navais excluíram os afro-brasileiros dos postos de oficiais, até o ponto em que a imprensa popular passou a se referir à cor de pele branca como requisito de admissão. Os periódicos de 1910 até 1923 estão repletos de relatos sobre a preferência por candidatos que fossem "o mais branco possível" para o serviço militar. (NASCIMENTO, 2007, p. 283-311)

Na mesma linha, em uma sessão legislativa de 1928, em São Paulo, sobre a possível aprovação de uma lei que acabava com a proibição do ingresso de afro-brasileiros na polícia local, assinalou-se que afro-brasileiros não poderiam ser admitidos como carcereiros ou policiais militares. (SÃO PAULO, 1928, p. 351) E, mesmo depois da aprovação da referida lei, ainda em 1928, a pele branca continuou a ser incluída como um requisito oficial para os candidatos 
quando solicitavam os documentos de ingresso. (DOMINGUES, 2004, p. 137) Os afro-brasileiros só puderam entrar na polícia depois de 1932.

Em uma lista de ocupações em São Paulo (com mais de 50\% dos imigrantes) elaborada em 1894, no pós-abolição, os trabalhadores estrangeiros representavam 82,5\% das ocupações essenciais à rápida expansão urbana e industrialização (manufaturas, ofícios, transporte, comércio), ao passo que os negros foram relegados à esfera do trabalho doméstico. Somente em São Paulo, 71,2\% dos trabalhadores naquele período eram estrangeiros. (REID ANDREWS, 1988, p. 491-524) Além do mais, nas áreas rurais que conseguiram atrair trabalhadores imigrantes em número suficiente, os imigrantes brancos também eram preferidos em detrimento dos negros emancipados. De fato, o ministro da Agricultura, Antônio Prado, propôs medidas para promover o estabelecimento de imigrantes na agricultura. (FERNANDES, 1971, p. 19) A preferência por imigrantes brancos também é demonstrada no estudo de Sam Adamo sobre práticas empregatícias no Rio de Janeiro da década de 1930. Adamo descobriu que os trabalhadores imigrantes brancos de baixa qualificação eram preferidos em detrimento dos afrodescendentes mais bem educados, ainda que os afrodescendentes recebessem menos. (ADAMO 1983, p. 62-80)

\section{A segregação racial por meio do direito costumeiro: a construção de espaços brancos}

Em São Paulo, o coração do projeto nacional de imigração para o branqueamento, os afro-brasileiros enfrentaram a exclusão e a segregação racial por obra do direito e dos costumes. O desejo por espaços brancos acompanhou o projeto de embranquecimento da população. Ao contrário do Nordeste, onde os afro-brasileiros constituem parcela significativa da população, em São Paulo e outras regiões do sul do Brasil, os afro-brasileiros eram minoria. A população afro-brasileira de São Paulo em 1886, dois anos antes da abolição, era de $24 \%$, e diminuiu para 16\% em 1928. (DOMINGUES, 2004, p. 188) Em contraste, em 1890, 61,4\% da população da cidade de Salvador era de afro-brasileiros, esse número aumentou para 64,9\% em 1940. (BUTLER, 1998, p. 134) Mesmo se relativizarmos a exatidão dos números do censo devido à maleabilidade política dos mesmos, o contraste entre o norte e o sul permanece se considerarmos a proporção relativa de afro-brasileiros por região. Desse modo, São Paulo e outras regiões do sul com menos afro-brasileiros estavam em melhor posição para usar o direito costumeiro para segregar os afro-brasileiros dos brancos. 
Isso ocorreu na década de 1920, com a indicação oral de ruas separadas para negros e brancos em São Paulo. (DOMINGUES, 2004, p. 157-162) Um conjunto de depoimentos orais de afro-brasileiros no período pós-abolição no sul do Brasil revelou reiteradamente os costumes arraigados de segregação racial em ruas, praças, jardins e parques públicos, tanto nas capitais como nas cidades do interior. Tais regras costumeiras voltadas à segregação racial em espaços públicos foram aplicadas pela polícia local, a qual prendia os afro-brasileiros que as violassem.

Os registros da história oral não narram nenhuma ação judicial contestando essas práticas prisionais. Na medida em que algum afro-brasileiro ousasse desafiar as prisões feitas pela polícia por violação das regras de segregação, os denunciantes teriam que enfrentar o difícil obstáculo da tradição brasileira de aplicar o direito costumeiro. A lei colonial de 1769, a Lei da Boa Razão, autorizava a aplicação legal de costumes sociais de uso prolongado. (SILVA, 2004, p. 6) Tais costumes tinham a força de direito (TELLES, 1824) e continuaram a ter essa força no período após a independência e também nos dias de hoje. (HADDAD, 2007) Deter os afro-brasileiros que invadiam os espaços socialmente designados aos brancos foi um costume com força de lei. Tendo em vista a imagem predominante do Brasil como uma nação sem uma versão própria das leis de segregação racial Jim Crow estadunidenses, é necessário rever essa visão para que se leve em conta as experiências regionais de segregação racial e seu caráter de direito costumeiro.

Locais abertos ao público também praticavam a segregação racial. Restaurantes paulistanos simplesmente se negavam a atender os afro-brasileiros que se atrevessem a entrar em restaurantes socialmente designados para brancos. Anúncios de casas estampavam: "Pessoas de cor não são aceitas", ou a frase racialmente codificada "Preferimos estrangeiros". Quando se encontravam afro-brasileiros vivendo perto de brancos, eram famílias numerosas de imigrantes que alugavam quartos e porões a afro-brasileiros para conseguirem uma renda extra. (BUTLER, 1998, p. 76) Os jornais afro-brasileiros da época noticiavam a recusa de atender clientes negros por parte de barbearias, hospitais e de muitos outros lugares de acesso público, bem como lojas. Na região de Campinas, avisos de "somente brancos" eram usados em teatros e outros lugares públicos. (NASCIMENTO, 1980, p. 206) Há relatos de segregação racial similares em cidades do interior do Rio de Janeiro.

Registros da polícia do Rio de Janeiro do tempo da abolição da escravidão até a década de 1890 revelam numerosos casos de afro-brasileiros detidos 
pela polícia simplesmente porque caminhavam durante a noite. (CHALHOUB, 1988, p. 83-105) Uma grande porcentagem de crimes reportados nessa época foi de crimes contra a ordem pública, tais como vadiagem, que eram usados para marginalizar afrodescendentes. (ADAMO, 1983, p. 228-242) Os registros policiais também indicam que acusações de vadiagem não serviam para condenar os afro-brasileiros, mas para rotulá-los de "indivíduos criminosos". (CUNHA, 2005, p. 295-315) De modo similar, na cidade de Rio Claro, a lei de vadiagem foi usada para impedir a presença de não brancos em espaços públicos "brancos” na tentativa de manter os recém-libertos em uma posição de subjugação. (DEAN, 1976, p. 151) Os recém-libertos foram segregados residencialmente do centro de Rio Claro e foram proibidos de passearem nos arredores da praça de Rio Claro.

Em Vasália, uma pequena cidade no noroeste do interior do Rio de Janeiro, os habitantes se recordam de uma "segregação ao estilo Jim Crow na rua principal, em lojas, passeios públicos, clubes sociais, danceterias e concursos de beleza, que durou até o recente ano de 1985”. (TWINE, 1998, p. 120) Na própria cidade do Rio de Janeiro, o governo redesenhou a cidade para limpá-la dos moradores afro-brasileiros. Com o seu "Primeiro Plano de Embelezamento e Saneamento do Rio de Janeiro", a capital foi reconstruída para a criação de uma "Paris tropical”. (JOHNSON, 2001, p. 23) Setecentos e sessenta edifícios na região central foram destruídos para deslocar os afro-brasileiros para regiões menos visíveis. O governo do Rio de Janeiro não queria afro-brasileiros vivendo no espaço que deveria parecer com a Europa "branca”. A racialização do espaço inaugurou um período de remoção de bairros informais que durou décadas e empurrou os afro-brasileiros para a periferia, onde não havia serviços públicos. (MEADE, 1996) Com efeito, o Rio se tornou duas cidades separadas em virtude de raça e classe. Similarmente, o governo federal também encorajou a racialização do espaço por meio da utilização de uma política de "somente brancos" no recrutamento de diplomatas e enviados especiais para missões no exterior, de modo que o Brasil fosse representado como uma nação branca. (SKIDMORE, 1990, p. 12)

\section{O projeto estatal de embranquecimento pela educação pública}

Assim como a política estatal de imigração foi orientada pelas noções de hierarquia racial eugênica, o modelo estatal de educação no período pós-abolição foi influenciado de forma parecida. O trabalho de Jerry Dávila detalha o modo pelo qual a elite nacional de cientistas associados à eugenia liderou e implementou 
várias iniciativas locais escolares que procuravam mitigar as deficiências de crianças afro-brasileiras e indígenas entre 1917 e 1945. (DÁVILA, 2003, p. 25) A despeito de o desenvolvimento de um sistema de educação pública ter sido concebido como mecanismo para qualificar todas as crianças igualmente com o fim de modernizar a nação, o sistema reproduziu hierarquias raciais preexistentes ao tentar embranquecer a população culturalmente. Gestores escolares e professores receberam formação em teorias culturais e comportamentais que explicavam as fraquezas raciais e as políticas eugenistas que as corrigiriam. Os preconceitos raciais de educadores brasileiros poderiam ser bastante manifestos, como os de Everardo Backheuser, que, em 1926, declarou que a diversidade racial na escola primária seria prejudicial ao país. (HENTSCHKE, 2007, p. 209)

A estruturação eugênica da educação pública começou no Rio de Janeiro em 1917. À época, o estado do Rio de Janeiro possuía o maior sistema escolar do país, o qual serviu de paradigma e foi adotado por outras regiões que frequentemente recebiam recursos federais para implementar o modelo. A Secretaria de Educação do Rio de Janeiro divulgava seus achados em uma revista quadrimestral distribuída aos professores de todo o país. Além do mais, o ministro de Educação e Saúde Pública deu carta branca para os eugenistas no Rio de Janeiro desenvolverem políticas e programas que, segundo eles, tivessem base científica. As políticas educacionais eugenistas incluíam segregação de estudantes por QI e "estado de saúde", além da implementação das equipes de inspeção ou das "brigadas de saúde”. Em 1958, a reforma eugênica do sistema público de ensino foi codificada através da Lei de Diretrizes e Bases da Educação, que foi mantida com pequenas alterações pelo legislativo em 1996. (BRASIL, 1996)

Para começar, estudantes foram segregados em salas de aula diferentes conforme sua capacidade intelectual medida pelos testes-padrão de QI com vieses raciais (os testes de QI desenvolvidos nos EUA foram aplicados no Brasil). As crianças de baixa capacidade não aprendiam a ler no primeiro ano, mas aprendiam a se "adaptar à vida escolar" com instruções sobre higiene pessoal. A medida era uma cilada para os estudantes afro-brasileiros na primeira série porque a falta de instrução acadêmica fazia com que os mesmos repetissem a primeira série até que, de alguma maneira, aprendessem a ler ou simplesmente abandonassem a escola por frustração.

Alunos também eram segregados ou completamente afastados da escola por conta do "estado de saúde" comprometido, o que favorecia a exclusão de crianças afro-brasileiras das séries adequadas ou da educação formal como um 
todo. Saúde comprometida incluía: sífilis, parasitas, adenopatias, anemia e indiferença à educação ou comportamento antissocial, presumivelmente, resultado de características hereditárias ou razões culturais. Tais estudantes eram frequentemente afastados da escola sob o pretexto de que eles colocariam em risco a saúde daqueles considerados aptos para aprender. A repetência era considerada um sintoma de doença.

As poucas crianças afro-brasileiras que conseguiam superar as barreiras de entrada e exclusão diária foram expostas a programas que procuravam mitigar suas más condições raciais e a programas de embranquecimento cultural. O programa mais importante do gênero era a "brigada de saúde”, que foi criada para melhorar os alunos eugenicamente. As brigadas de saúde, organizadas em cada sala de aula, contavam com um estudante responsável por inspecionar a higiene dos colegas diariamente e fazer o respectivo registro em um quadro afixado na porta da sala de aula. Aqueles estudantes com higiene ruim (inevitavelmente os afro-brasileiros) eram enviados à diretoria para uma aula extra de higiene em vez de receber o ensino regular em sala de aula. Portanto, em vez de ensino acadêmico, os alunos afro-brasileiros eram submetidos à instrução de como lavar o rosto, orelhas, cabelo; escovar os dentes; aparar as unhas e lustrar os sapatos. Consequentemente, as crianças afro-brasileiras recebiam noções rudimentares de leitura, e quando recebiam, apenas na terceira série, pois os educadores, até então, enfocavam o ensino de hábitos de higiene para que essas crianças melhorassem eugenicamente para a sociedade. Além disso, programas musicais europeus foram instituídos para civilizar os estudantes não brancos e encorajá-los a abandonar a degenerada música carnavalesca de matriz africana.

As crianças afrodescendentes que realmente tiveram alguma exposição a um conteúdo acadêmico sofriam agressões por meio de livros didáticos com conteúdo preconceituoso. (NAVA, 1998, p. 39-63) Por exemplo, ainda no ano de 1964, o livro didático oficial para geografia e história do Brasil afirmava que "de todas as raças, a raça branca é a mais inteligente, perseverante e empreendedora [...] a raça negra é muito mais atrasada do que as outras”. (HENTSCHKE, 2007, p. 142)

O embranquecimento da educação também implicava a exclusão de afro-brasileiros da carreira docente. Ainda que houvesse professores afro-brasileiros durante as primeiras duas décadas do século XX, os quais haviam recebido instrução de instituições religiosas, esse quadro foi alterado pelas reformas educacionais levadas a cabo pelo governo do Rio de Janeiro. Desde 1917, para 
se tornar professor, era necessário um curso específico formatado de maneira similar aos cursos universitários de ciências sociais. Antes desse período, um diploma de ensino médio era suficiente para lecionar em uma escola primária em qualquer lugar do Brasil. Os afro-brasileiros inevitavelmente encontraram dificuldades de obter esse novo título. $\mathrm{O}$ treinamento profissional oferecido na "escola normal", inspirado no modelo do Columbia Teachers College, exigia um exame de admissão tão rigoroso que os candidatos faziam um curso preparatório com um ano de duração em uma escola privada. Tais cursos preparatórios estavam fora do alcance financeiro da maioria dos afro-brasileiros, que possuíam resultados insatisfatórios, os quais, por sua vez, confirmariam a presumida deficiência de candidatos afro-brasileiros. Testes psicológicos dos candidatos também foram empregados para confirmar a inaptidão para educar decorrente da raça. Além disso, também se exigia que os candidatos tivessem determinado peso e altura, os quais, de forma eugênica, correspondiam a um tipo de corpo o mais próximo possível dos padrões europeus. Como resultado, o educador médio de escola pública passou a ser a mulher branca de classe média, treinada para conceber seus alunos dentro de uma perspectiva racial. (DÁVILA, 2003)

Os poucos estudantes afro-brasileiros afortunados o bastante para conseguir que algum branco patrocinasse sua educação em uma escola privada corriam o risco de não serem admitidos por razões administrativas, pois outros pais poderiam retirar seus filhos como forma de protesto. (HENTSCHKE, 2007, p. 143) Dessa maneira, as escolas privadas preservariam sua exclusividade branca, enquanto os afrodescendentes eram mantidos segregados nas problemáticas escolas públicas primárias.

\section{Regulação de religiōes de matriz africana como branqueamento}

Assim como fez no sistema público de educação, o governo brasileiro também implementou seu projeto de branqueamento por meio de uma opressiva regulação das práticas religiosas de matriz africana. Após a independência e a abolição da escravidão, o Brasil decretou a separação entre a Igreja e o Estado em 7 de janeiro de 1890 . O artigo $2^{\circ}$ do Decreto 119-A dispunha que "a todas as confissões religiosas pertence por igual a faculdade de exercerem o seu culto, regerem-se segundo a sua fé e não serem contrariadas nos atos particulares ou públicos, que interessem o exercício deste decreto”. (JOHNSON, 2001, p. 23) 
Todavia, a despeito do decreto, grupos religiosos de matriz africana foram alvo de intenso escrutínio governamental por meio do direito penal e administrativo. A situação não mudou quando as provisões do decreto de liberdade religiosa foram incorporadas à Constituição de 1891.

O Código Penal de 1890 continha novos artigos que foram usados para tornar ineficaz o direito de liberdade religiosa para grupos religiosos de matriz africana. (MAGGIE, 1992, p. 22-23) O artigo 157 proibia "Praticar o espiritismo, a magia e seus sortilégios, usar de talismãs e cartomancias para despertar sentimentos de ódio ou amor, inculcar cura de moléstias curáveis ou incuráveis, enfim, para fascinar e subjugar a credulidade pública”. O artigo 158 proibia "Ministrar, ou simplesmente prescrever, como meio curativo para uso interno ou externo, e sob qualquer forma preparada, substância de qualquer dos reinos da natureza, fazendo, ou exercendo assim, o oficio do denominado curandeiro". Além disso, a Lei ${ }^{\circ} 173$, aprovada em 1893, garantia direitos apenas às associações religiosas oficialmente registradas e que não promovessem fins ilícitos ou imorais. Todas essas provisões legais foram usadas em conjunto para impedir práticas religiosas de matriz africana consideradas algo socialmente nocivo e uma ameaça à saúde pública, sob os auspícios do Serviço de Higiene Administrativa da União. Essa orientação estava em conformidade com a concepção geral de que os afro-brasileiros constituíam um problema de higiene social para o país. (TROCHIM, 1988, p. 285-300)

As religiões de matriz africana eram tratadas como magia ilegal e efetivamente não abrangidas pelo conceito de religião, fazendo com que a prática religiosa oficial brasileira e a identidade nacional fossem brancas. Como consequência, forças policiais invadiam e destruíam centros religiosos de matriz africana (terreiros de candomblé, centros de macumba, umbanda, xangô, tambor de Minas e espiritismo), além disso, assediavam e prendiam os praticantes e confiscavam seus objetos ritualísticos.

Mesmo a região Nordeste, predominantemente negra, sofreu perseguição policial. (BASTIDE, 1978, p. 164) E, na Bahia, agentes do governo chegaram ao ponto de, em 1902, proibir os tambores de clara origem africana nas festas profanas de Carnaval. (FRY; CARRARA; MARTINS-COSTA, 1988, p. 259) A elite baiana preocupada há muito tempo em ser vista pelo resto do país como "os brancos da Bahia", ou seja, menos brancos por causa da desconfiança de que seus ancestrais seriam mestiços em um Nordeste predominantemente negro. Provavelmente, a insegurança da elite baiana, devido ao questionamento 
nacional de sua branquitude, exacerbou o desejo de dissociarem-se da cultura e religião de matriz africana. (BUTLER, 1998, p. 185)

A regulação de religiões de matriz africana se modificou pouco durante o regime de Getúlio Vargas (1930-1945), que buscava uma imagem de unidade nacional. Enquanto o Decreto Presidencial n ${ }^{\circ} 1202$ de Vargas reconhecia a legitimidade de casas tradicionais de candomblé praticarem seu culto, deixou para a polícia a responsabilidade de distinguir os grupos que não eram "tradicionais”, considerados praticantes de bruxaria, magia e curas fraudulentas. O requerimento que grupos religiosos faziam ao Estado os tornava particularmente vulneráveis à regulação e à perseguição policial. (similarmente, leis baianas de 1932 declararam que capoeiristas eram "delinquentes perigosos", sujeitando-os à perseguição policial). (BUTLER, 1998, p. 187) De fato, um departamento policial inteiro ("Polícia de Costumes") foi criado por Vargas, em 1934, para regular e distinguir as práticas religiosas legítimas das práticas ilegais. O registro federal das religiões no Departamento de Costumes só deixou de ser obrigatório em 1974, fazendo com que os praticantes de religiões de matriz africana fossem marginalizados em uma nação idealizada como branca, representada pela famosa estátua do Cristo branco no topo do Corcovado, inaugurada em 1931.

O ápice das várias faces do projeto estatal de branqueamento foi o visível embranquecimento da região sul do Brasil. Porém, o interesse em continuar a busca por imigrantes europeus diminuiu devido à crescente atividade sindical desenvolvida por eles. A atividade sindical dos europeus imigrantes foi significativa e os movimentos grevistas foram numerosos entre 1917 e 1920. (MARAM, 1979, p. 215-223) Ainda que as elites governantes fossem relutantes em deportar os imigrantes, nos quais muito dinheiro foi investido para que viessem ao Brasil, elas decidiram finalmente suspender o programa de estímulos à imigração em 1927. (MARAM, 1977, p. 254-272) A esse programa, seguiram, em 1931, as restrições impostas pelo governo federal à imigração, bem como ao emprego de estrangeiros no comércio e na indústria, nos termos do Decreto n. 20.921. (BRASIL, 1931)

\section{Do branqueamento à mestiçagem}

Sem o afluxo de mais imigrantes europeus, o Brasil continuou tendo uma população nacional de ancestralidade visivelmente africana e indígena. O desejo do Estado Nacional de promover uma imagem internacional de civilização (a 
despeito da presença daqueles considerados racialmente não civilizados) despertou o interesse do governo em relação às teorias do sociólogo brasileiro Gilberto Freyre, um filho da elite branca do Nordeste mestiço.

As obras publicadas por Freyre entre 1930 e 1970 representaram um deslocamento conceitual do branqueamento sem jamais questionar a crença na superioridade branca. Freyre (1936) descreveu o desenvolvimento do Brasil como um conjunto de encontros íntimos entre as raças do qual resultou a criação de uma nova raça. Através da mestiçagem - mistura racial - foi criada uma "raça brasileira", que por sua vez presumia a inexistência de conflitos raciais na sociedade. A cultura brasileira também era resultado da mistura racial, mas Freyre considerava a contribuição europeia como a mais evidente e importante. Desse modo, a ideia de mestiçagem se assemelha ao discurso de mestizaje da América Hispânica e à descrição de José Vasconcelos de uma "raça cósmica", racialmente mista, mas essencialmente branca como discutido no capítulo anterior.

Apesar de Freyre ter usado o termo "racial democracy" (democracia racial) em algumas palestras e declarações a um público falante de inglês com o objetivo de descrever o caminho adotado pelo Brasil rumo à mestiçagem, ele não criou o termo. De fato, o reconhecido historiador George Reid Andrews observou que escritores e intelectuais brasileiros já discutiam a questão da democracia racial desde a década de 1880. (REID ANDREWS, 1996, p. 488) Contudo, foram talvez as publicações de 1965 do sociólogo brasileiro Florestan Fernandes, posteriormente traduzidas para o inglês em 1971, questionando o "mito da democracia racial", que deram ao termo uma maior difusão acadêmica. (FERNANDES, 1971, p. 137) Apesar disso, Freyre é amplamente reconhecido como o autor da tese da mistura racial que hoje se conhece como "democracia racial". (LEHMANN, 2008, p. 209-210) Pode ser que o entusiasmo do governo brasileiro pelas ideias de Freyre tenha levado à associação entre Freyre e o termo "democracia racial".

O discurso populista do regime de Getúlio Vargas (1930-1945) se ajustava bem à ideologia de mestiçagem de Gilberto Freyre, que foi diretamente incorporada aos projetos de construção nacional do governo. A mestiçagem foi considerada a verdadeira nacionalidade do brasileiro e foi promovida em solenidades públicas, escolas, universidades e na mídia nacional. (REID ANDREWS, 1996, p. 488) Quando Vargas se consolidou no poder como ditador, em 1937, aboliu todos os partidos políticos, incluindo a Frente Negra Brasileira, a qual tinha se organizado como um partido em 1930 e se registrado oficialmente em 
1936. (SKIDMORE, 1967) Além disso, o censo novamente se tornou o local de validação da ideologia racial do governo.

Assim como os dados eram empregados para validar a política de branqueamento da população, com a mudança para a política da mestiçagem, os dados do censo foram usados para exaltar a proeminência da mistura racial. Com frequência, isso foi feito de forma dissociada dos dados estatísticos reais a respeito da raça da população. Por exemplo, no censo de 1940, os resultados foram apresentados com um relatório elaborado para ressaltar o progresso da nova raça brasileira. (AZEVEDO, 1950, p. 33) Contudo, a nova raça mista brasileira foi celebrada no relatório do censo como um indicador de como "negros e indígenas continuam a desaparecer" no constante processo de seleção social e biológica, e que a imigração, especialmente a de origem mediterrânea, continua. O homem branco não apenas terá no Brasil um espaço privilegiado para a vida e cultura nos trópicos, mas poderá conectar-se com a velha Europa, cidadela da raça branca. (AZEVEDO, 1950, p. 41) A precisão das previsões comparativas dos relatórios do censo, claro, não podia ser aferida, já que o censo não foi realizado em 1930 ou 1910, e a questão sobre cor/raça ficou fora do censo de 1920. Além do mais, pelo menos um demógrafo sugeriu que as estatísticas raciais no Brasil foram por vezes intencionalmente alteradas para indicar uma população mais branca. Por exemplo, em uma publicação de 1940, Samuel Lowrie observou que, em termos absolutos, a população negra de São Paulo estava, na verdade, aumentando, a despeito de muitos de seus membros terem sido estatisticamente transferidos da categoria racial negra para branca. (LOWRIE, 1942, p. 398-416)

No censo de 1950, com a mudança na metodologia do recenseamento, em vez de serem listadas as categorias de cor, os cidadãos deveriam autodeclarar-se, tendo assim em suas mãos o poder do embranquecimento simbólico. Consequentemente, não foi surpresa quando o censo de 1950 indicou uma diminuição de 3,6\% no número de negros em relação a 1940, e um aumento de 5,3\% no número de pardos (categoria que inclui não apenas mestiços, mas também descendentes de indígenas). (NOBLES, 2000, p. 105) Novamente, o relatório do censo publicado celebrou o progresso da nação no caminho do embranquecimento da população por meio da mestiçagem. (BRASIL, 1970, p. 169)

Enquanto os dados raciais do censo de 1960 nunca foram totalmente divulgados, o regime militar, que tomou o poder em 1964 e governou até 1985, estava tão convicto da ideia de democracia racial, que caracterizava qualquer 
crítica à democracia racial como um "ato de subversão". (AZEVEDO, 1975, p. 53) Além disso, a formação de grupos negros era proibida por ser considerada segregacionista e racista. A intolerância do regime militar a qualquer crítica à democracia racial aumentou com a decisão de não incluir uma questão de cor/ raça nos questionários do censo de 1970. Ironicamente, o regime militar não tinha qualquer razão para temer questões de cor/raça no censo. No ano de 1976, uma pesquisa domiciliar nacional foi realizada com uma questão aberta sobre cor e a população respondeu com 135 tipos diferentes de cor. (BRASIL, 1976) Em resumo, o culto à mestiçagem já tinha se apoderado das identidades raciais dos brasileiros que buscavam alguma categoria racial que não fosse negra para se identificar. Contudo, os militares ainda queriam que o censo de 1980 não tivesse a categoria “cor/raça”. Somente com a abertura democrática, que começou no final dos anos da década de 1970, durante a qual cientistas sociais e ativistas negros fizeram lobby, a questão sobre cor/raça foi restaurada no censo de 1980. Contudo, a reintrodução da questão sobre a cor em todos os questionários dos censos seguintes não alterou a mentalidade nacional sobre a democracia racial tão cuidadosamente cultivada pelo governo.

Logo no início da campanha de "brasilidade" de Getúlio Vargas, os brasileiros passaram a ser expostos a diversos projetos de propaganda governamental que promoviam a brasilidade e a mestiçagem como a única identidade nacional adequada. Isso incluía um programa diário de rádio, a Hora do Brasil. (DAVIS, 1992, p. 249) A influência da brasilidade promovida pelo governo também foi disseminada através de rigorosas orientações a respeito do currículo escolar e dos livros didáticos. Os professores do ensino primário eram orientados a explicar a formação do povo brasileiro como a combinação do "branco, que contribuiu com a língua, os costumes e a religião; o negro, que nos legou a gentileza e o espírito de sacrifício do africano; os indígenas, que nos transmitiram o amor pela liberdade e a ligação com a terra, que são sentimentos inatos do brasileiro". (DAVIS, 1992, p. 252-253) Essa doutrinação continuou na escola secundária e na universidade com o uso do livro Casa Grande e Senzala, de Gilberto Freyre, como um "texto clássico" (no qual ele caracterizou a escravidão brasileira como suave porque o colonizador português seria aberto a aceitar o outro, bem como a contrair matrimônio com pessoas de outras raças e culturas).

$\mathrm{O}$ apego nacional à ideologia da democracia racial também foi facilitado pela preocupação latino-americana com o imperialismo. Sem dúvida, o Brasil estava fora do campo de intervenção política dos Estados Unidos (ao contrário 
de Cuba e Porto Rico no período pós-independência). No entanto, o desejo por investimentos estrangeiros para estimular a modernização e a industrialização foi acompanhado do receio de ser considerada uma nação "vira-lata", sujeita à influência e à interferência externas. Portanto, a atenção nacional para a opinião externa encorajou todos os brasileiros a se considerarem unidos contra qualquer inferioridade imposta a partir do estrangeiro. De fato, o Brasil e a América Hispânica foram descritos por Darién Davis como portadores de um "complexo de inferioridade", contra o qual o patriotismo foi a defesa que resultou na cooptação de minorias étnicas. (DAVIS, 1992, p. 230, 253-260) O conceito de democracia racial da mestiçagem brasileira (e mestizaje na América Hispânica) foi uma fonte útil de orgulho nacional em contraposição às leis Jim Crow nos Estados Unidos. Ao mesmo tempo, a racialização dos espaços patrocinada pelo Estado permitiu que as identidades regionais permanecessem baseadas em raça sem que isso fosse considerado contraditório à noção de democracia racial. Por exemplo, em São Paulo, a identidade paulista, em 1930, foi associada à branquitude da modernidade, indústria e progresso econômico. (WEINSTEIN, 2003, p. 237-262) A identidade paulista, e da região Sul como um todo, foi racialmente associada ao branco em contraposição à negritude e ao atraso da região Nordeste. De fato, logo após Getúlio Vargas assumir o poder, em 1930, o governo do estado de São Paulo declarou guerra contra o governo central porque Vargas indicou um nordestino "atrasado" como governador interino do estado de São Paulo. Durante 83 dias, a partir de 9 de julho de 1932, as tropas do estado de São Paulo lutaram com as tropas federais. A guerra de São Paulo foi caracterizada à época como uma luta para defender "a cultura de homem branco" contra o populismo da "ditadura negra” de Vargas. (WEINSTEIN, 2003, p. 246-247) Inferiores numericamente e mal-equipados, os paulistas negociaram um acordo com o governo central, mas mantiverem sua convicção de que São Paulo deveria ser mais valorizado no país por causa de sua cultura mais civilizada. Mais importante ainda, as diferenças regionais de raça eram compreendidas no Brasil como coexistindo com uma democracia racial, que retratava uma harmonia sobre um pano de fundo de hierarquia racial presumida. Por sua vez, isso ajuda a explicar o duradouro fenômeno das altas taxas de casais compostos por indivíduos da mesma raça em uma democracia racial. (CAULFIELD, 2003, p. 163186; LOWRIE, 1939, p. 684-707)

De fato, uma característica significativa da democracia racial da mestiçagem é seu poder de negar a articulação de diferenças raciais, enquanto apoia 
a existência de uma hierarquia racial e da exclusão socioeconômica como algo que não estaria relacionado à raça, mas à classe. As décadas de políticas de branqueamento patrocinadas pelo Estado asseguraram a subordinação de afro-brasileiros, subordinação que a democracia racial da mestiçagem faz crer ser obra do acaso. Por essa razão, apenas recentemente, a autoridade do mito da democracia racial começou a ser questionada no Brasil e também na América Hispânica. Ainda que as leis de imigração brasileiras e o direito costumeiro de segregação não possam ser comparados diretamente com o contexto da legislação Jim Crow estadunidense, considerar a semelhança dos fins e as consequências das duas formas de regulação racial faz cair por terra o mito de que os governos brasileiros foram inocentes no que diz respeito à regulação racial. Nos capítulos a seguir, detalharei o legado da mestiçagem brasileira e do mestizaje latino-americano, bem como a barreira que esse legado representa para atingir a igualdade racial na região, questões que também ecoam o legado das desigualdades raciais forjadas pela segregação racial baseada na legislação Jim Crow nos Estados Unidos. 


\section{A exclusão social dos afrodescendentes na América Latina de hoje}

'Onde estão todos os negros?', perguntou Jean Paul Sartre ao visitar uma universidade no Rio de Janeiro. (MARTINS, 2008, p. 37-46, 42)

Apesar de historicamente terem travado diversas batalhas pela independência e, em seguida, pela abolição da escravidão no período pós-colonial, os afrodescendentes de hoje continuam sendo um grupo marginalizado. Pesquisas na América Latina indicam que estereótipos negativos sobre os negros permeiam a sociedade e permanecem intocados desde a escravidão. (REID ANDREWS, 2004, p. 178) A pesquisa também mostrou que tais estereótipos são veiculados tanto por membros da classe trabalhadora como pelos das classes mais altas.

Enquanto as constituições latino-americanas promovem a igualdade formal para todos, os afrodescendentes avançaram muito pouco em termos econômicos desde a abolição. ${ }^{1}$ De fato, apesar de os afrodescendentes terem uma

1 Ver em: Argentina, 1994, art. 16; Bolívia, 2009, art. 6; Chile, 1980b, art. 19; Colômbia, 1995, art. 13; Costa Rica, 1949, Art. 33; Cuba, 1992, cap. VI, Art. 42-43; República Dominicana, 2002, Art. 8; Equador, 2008; El Salvador, 1998, tít. II, cap. I, art. 3, p. 1; Guatemala, art. 4, 1985; Honduras, 1997, tit. III, cap. 1, art. 60, p. 16; México, 1917, art. 1, 3; Nicarágua, 1998, tít. IV, cap. 1, art. 27, p. 6; Pana- 
presença significativa na maior parte da América Latina, possuem limitada participação na política e no governo.

$\mathrm{Na}$ América Latina, os descendentes de africanos são desproporcionalmente pobres e analfabetos, têm limitado acesso à educação e oportunidades de emprego, resultando em uma menor expectativa de vida. (PARDO, 2008) A maior parte dos afrodescendentes vive em áreas rurais e sofre com falta de infraestrutura e serviços públicos como, por exemplo, a ausência de serviços de saúde e escolas, além de sustentarem altas taxas de desemprego e baixa renda. (SÁNCHEZ; BRYAN, 2003, p. 3) Os pesquisadores atribuem o baixo crescimento econômico de países da América Latina e do Caribe à exclusão discriminatória de afrodescendentes. (ZONINSEIN, 2001) Além disso, as pesquisas atribuem o pior desempenho econômico, comparativamente aos países do leste asiático e do leste europeu, à exclusão das populações rurais pobres (grande parte das quais é de afrodescendentes) de serviços e proteção social. (KAUFMANN; HAGGARD, 2008) A despeito da variação na densidade demográfica e histórias políticas, estudos sobre a América Latina revelam uma notável semelhança entre a marginalização dos afrodescendentes e a discriminação que enfrentam. (FORUM, 1996)

Em grande parte da região, os afrodescendentes são considerados os "mais pobres entre os pobres”. Os afrodescendentes representam 30\% da população latino-americana, mas quando as taxas de pobreza são estimadas por raça, representam $40 \%$ dos pobres da região. (MÁRQUEZ et al., 2007, p. 15-17) A situação dos afrodescendentes é particularmente sombria se considerarmos que a América Latina é a região com a pior distribuição de renda no mundo. Além do mais, a exclusão social dos afrodescendentes permanece inalterada mesmo quando as pesquisas são controladas, em termos de nível de renda, para fins de análise estatística.

Considerando o contexto da Colômbia, país da América Hispânica que conta com a maior população afrodescendente (entre 10 e 17 milhões de pessoas), observa-se que $80 \%$ dos afro-colombianos vivem abaixo da linha da pobreza. (CEVALLOS, 2005) Das comunidades negras colombianas, $98 \%$ não contam com serviços públicos, ao passo que apenas $6 \%$ das comunidades brancas estão em situação similar. Há também disparidades no atendimento de saúde.

má, 1995, Tít. III, cap. 1, Art. 19, p. 105; Paraguai, 1992, art. 88; Peru, 1995, tít. I, cap. I, art. 2, Cl. 2, p. 113; Venezuela, 2000, tít. III, Cap. 1, art. 21, p. 4. 
Enquanto $40 \%$ das comunidades brancas colombianas têm atenção em saúde, apenas $10 \%$ das comunidades negras contam com tal cobertura. Os baixos salários nas comunidades colombianas afrodescendentes torna ainda mais difícil o acesso a serviços de saúde, porque remédios e consultas médicas não são oferecidas gratuitamente. Como resultado, a taxa de mortalidade infantil da população afrodescendente é quase duas vezes maior que a média nacional colombiana. (INTER-AMERICAN COMMISSION ON HUMAN RIGHTS, 2009, obs. 36) Ainda que a Colômbia, Cuba e o Brasil sejam países que possuem uma grande população afrodescendente e significativa desigualdade racial, a subordinação racial também existe em nações que possuem uma população pequena de afrodescendentes e maiores proporções de populações indígenas marginalizadas. Por exemplo, no Peru, onde se estima que em torno de 1,5 e $10 \%$ da população seja afrodescendente, a taxa de pobreza do grupo excede a média nacional, assim como sua renda média é menor do que a média nacional. (PERU, 2011, p. 44, 108-109) O acesso à cobertura de saúde também é menor do que a média nacional, como resultado do tratamento discriminatório nos centros de saúde. (PERU, 2011, p. 48-53) Por exemplo, afro-peruanos esperam mais tempo por atenção médica e, quando são finalmente atendidos, são examinados superficialmente e rapidamente liberados. Mulheres afro-peruanas também notam que, durante consultas médicas, os profissionais frequentemente se referem a elas empregando termos sexuais racializados em vez de as tratarem pelos seus respectivos nomes. (PERU, 2011, p. 51-53) Similarmente, no Equador, $81 \%$ dos afrodescendentes vivem abaixo da linha de pobreza e a taxa de mortalidade infantil do grupo de crianças com menos de cinco anos é de 48,3\%, enquanto a do mesmo grupo de crianças brancas é de 30,8\%. (QUEST, 2000, p. 6; PUEBLOS INDÍGENAS Y AFRODESCENDIENTES DE AMÉRICA LATINA Y EL CARIBE, 2006, p. 437) Além disso, a taxa de afro-equatorianos conectados ao sistema de telefonia é metade do resto da população equatoriana. No Uruguai, conforme o censo de 2006, 9,1\% da população é afrodescendente, mas a taxa de pobreza do grupo é o dobro da taxa de pobreza dos uruguaios brancos. (REID ANDREWS, 2010, p. 160)

A segregação geográfica também influencia a marginalização de afrodescendentes na América Latina. Nas áreas residenciais onde os afrodescendentes se concentram, a qualidade da moradia e o acesso a serviços públicos são desproporcionalmente deficientes. (GIRALDO; ECHEVERRY, 2000, p. 1; PARODI, 2001, p. 14) Além do mais, o investimento governamental em 
infraestrutura nessas áreas é inadequado. Como resultado, os afrodescendentes têm menos acesso a serviços públicos na América Latina como um todo. Por exemplo, na Colômbia, as áreas que são densamente povoadas por afro-colombianos são extremamente pobres. Vale notar que o município com o maior percentual de afro-colombianos tem o menor investimento governamental per capita em saúde, educação e infraestrutura. (MÁRQUEZ et al., 2007, p. 2224) Os baixos níveis de acesso a serviços públicos e a baixa qualidade dos mesmos, em comunidades afro-colombianas, são os principais determinantes dos baixos níveis de bem-estar do país. Ainda que a segregação geográfica na América Latina seja certamente influenciada pela correspondência entre ascendência africana e condição de pobreza, também há evidências indicando a existência de uma regulação informal para que os espaços sejam mantidos "brancos". Jornalistas têm observado a ascensão de grupos racistas skinheads que atacam afrodescendentes que circulam por bairros de classe média alta, restaurantes e casas noturnas na Colômbia, no Uruguai e na Venezuela. (REID ANDREWS, 2004, p. 195)

Além do mais, a maioria dos afrodescendentes na América Latina tem pouco ou nenhum acesso à educação fundamental e ao ensino médio de qualidade. (RIGHT, 2008, p. 3) Essa privação contrasta com o direito constitucional à educação que as constituições latino-americanas asseguram a todos os cidadãos. ${ }^{2}$ A educação limitada oferecida aos afrodescendentes é evidenciada nas instalações educacionais dilapidadas, na falta de professores de alta qualidade e de materiais educacionais. Estudantes de ascendência africana são relegados a escolas públicas subfinanciadas tanto na educação primária quanto na educação secundária, ao passo que crianças brancas economicamente privilegiadas frequentam escolas privadas com muito mais recursos. (WOLFF; CASTRO, 1999) Até mesmo a seleção de professores é racialmente estratificada. (ALBORNOZ, 1993; GENTILI, 2003)

2 Ver em: Argentina, 1994, art. 5, 75, par. 17, 19; Bolívia, 2009, art. 177, par. I-III, art. 180; chile, art. 10, 11; Colômbia, 1995, art. 44, 64, 67-69; Costa Rica, 1949, art. 79; Cuba, 1992, art. 39, par. B; Equador, 2008, art. 23, par. 20, art. 49, 53, 63; República Dominicana, 2002, art. 8, par. 16; El Salvador, 1983, art. 35, 53, 56, 58; Guatemala, 1985, art. 71, 73, 74; México, 1917, art. 2, par. B, § II, art. 3, par. IV, V, art. 4; Nicarágua, 1998, art. 105, 119, 121, 125; Panamá, 1995, art. 52, 87, 90, 91, 96, 104; Paraguai, 1992, art. 73, 74, 76, 77; Peru, 1993, art. 13, 16, 17; Uruguai, 1967, art. 68, 70-71; Venezuela, 2000 , art. 102, 103, 121) [24] 
Como resultado, na América Latina, as taxas de analfabetismo entre os afrodescendentes são desproporcionalmente altas se comparadas ao restante da população. Do mesmo modo, os afrodescendentes tendem a não completar os estudos devido a barreiras tanto na educação primária como na secundária. Tal disparidade racial nos níveis educacionais é explicável em razão da segregação racial de fato no sistema educacional latino-americano. (ALBORNOZ, 1993, p. 6, 141) O caráter intencional da segregação educacional pode ser visto na declaração "no cholo", expressão de variação indígena do espanhol peruano utilizada nas universidades de elite em Lima; e "no negro", expressão similar utilizada nas universidades de elite de Caracas. (ALBORNOZ, 1993, p. 141) Tais atitudes racializadas que permeiam as sociedades latino-americanas podem, por sua vez, ajudar a explicar as razões pelas quais os governos latino-americanos negligenciam o sistema público de educação primária e secundária. (SAUTU, 1999, p. 23-27)

A desigualdade racial do sistema educacional latino-americano pode ser exemplificada pela significativa disparidade racial nos resultados educacionais. Por exemplo, 31,3\% dos afro-colombianos são analfabetos, uma taxa quase três vezes maior que a do restante da população. (SÁNCHEZ; GARCÍA, 2006, p. 16,38) Apenas 13\% dos afro-colombianos maiores de 18 anos de idade completaram a educação fundamental. (COLÔMBIA, 2006, p. 159) Apenas 7,07\% dos matriculados em cursos de pós-graduação são afrodescendentes. ${ }^{3} \mathrm{Na}$ região do Pacífico, onde a maioria dos afro-colombianos reside, a cada 100 mil estudantes que completam o ensino médio, apenas $2 \%$ ingressam na universidade. (JUSTICE STUDIES CENTER OF THE AMERICAS, 2004) Sendo que, dos estudantes que conseguem entrar na universidade, muitos não conseguem completar seus estudos. De modo similar, no Equador, a taxa de matrículas de afro-equatorianos no ensino médio é de $36,7 \%$, comparada a 55,7\% para os brancos. Na universidade, a taxa de matrícula de afro-equatorianos é de 5,5\% e de 16,8\% para os brancos. (PUEBLOS INDÍGENAS Y AFRODESCENDIENTES DE AMÉRICA LATINA Y EL CARIBE, 2006, p. 435) A taxa de analfabetismo para os afro-equatorianos é de 10,3\% e de 4,7\% para os brancos. No Peru, os afro-peruanos possuem taxas de matrícula no ensino fundamental, médio e superior desproporcionalmente inferiores às taxas do resto da

3 Colombia, Viceministerio de Enseñanza Preescolar, Básica y Media, "Direction of Order and Equity", 2007. Disponível em: <www.mineducacion.gov>. 
população. (PERU, 2011, p. 56-62) No Uruguai, a taxa de matrícula de afro-uruguaios em universidades é quase a metade da mesma taxa dos uruguaios brancos. Ainda mais eloquente é o fato de que os afro-uruguaios, em termos salariais, recebem menos, por ano de educação, que os uruguaios brancos. (REID ANDREWS, 2010, p. 150, 161)

A natureza hierárquica do sistema educacional latino-americano assegura que a maioria dos afrodescendentes não possa usar a educação como uma via de mobilidade social vertical. Estudos em setores da economia que apresentam baixa disparidade racial no nível educacional dos empregados mostram que afrodescendentes recebem menores salários. (MÁRQUEZ et al., 2007, p. 2426) Dessa maneira, as distorções do sistema educacional e a discriminação no mercado de trabalho se combinam para subordinar os afrodescendentes. Por exemplo, vários estudos na Colômbia demonstram que, independentemente da vantagem educacional que um candidato a emprego afro-colombiano possa ter, a discriminação racial reduz suas oportunidades de emprego e de salário. (BARBARY; URREA, 2004)

A discriminação racial no mercado de trabalho predomina em toda a região e tem um importante papel na determinação de vagas de emprego e oportunidades de carreira. Isso é evidente nos contextos ocupacionais nos quais a educação formal não é um requisito relevante para o recrutamento. Estudos dos padrões de contratação na América Latina têm revelado que empregadores relutam em contratar afrodescendentes para cargos de direção, cargos profissionais, técnicos e de gestão; e mesmo para cargos de baixa remuneração no comércio varejista e no setor de vendas. (REID ANDREWS, 2004, p. 179) A pequena classe média negra que existe na América Latina é empregada principalmente em órgãos públicos. Uma vez contratados, os afrodescendentes são colocados em posições de baixo prestígio, com menores possibilidades de ascensão profissional, mas com alta probabilidade de demissão.

O uso de estereótipos raciais, como detalhado no capítulo 1, facilita também a exclusão dos afrodescendentes, porque as visões racializadas se tornaram algo tão impregnado no tecido social latino-americano que a condição de subordinado de afrodescendentes na força de trabalho é naturalizada e considerada decorrente da lógica. (WADE, 2006, p. 105-124) Por exemplo, no Peru, a preferência por pele mais clara é tão disseminada que os negros só são considerados atraentes quando sua aparência denota mistura racial com brancos ou indígenas. (GOLASH-BOZA, 2011, p. 158) Essa situação se manifesta nos 
dados que mostram um padrão estatisticamente significativo no qual a raça influencia nos padrões de renda e induz a segregação no mercado de trabalho. (SIMS, 1996, p. 2) De fato, $40 \%$ dos afro-peruanos trabalham em empregos de baixa qualificação. A maioria dos afro-peruanos está empregada em posições de baixo prestígio social, como motoristas, porteiros, carregadores de caixão ou babás. Além do mais, no Peru, os anúncios de empregos para motoristas, cozinheiros, porteiros, copeiros e empregadas domésticas frequentemente declaram abertamente a preferência por não brancos (negros ou morenos). Os afro-peruanos geralmente não ocupam posições de liderança no governo ou no setor empresarial, além de haver uma crença generalizada de que a Marinha e a Força Aérea "seguem políticas não oficiais para excluir negros do quadro de oficiais”. (U.S. DEPARTMENT OF STATE, 2000)

De modo similar, na Cuba socialista, os afro-cubanos são sistematicamente excluídos de empregos no setor turístico, uma vez que os empregadores exigem "boa aparência”, assim como os empregadores no Peru, na Venezuela e em várias partes da América Latina. (REID ANDREWS, 2004, p. 179, 194) Estudos que comparam pessoas com o mesmo grau de instrução formal mostram que, em Cuba, a preferência pela branquitude no mercado de trabalho persiste. (SAWYER, 2006, p. 138-145) Em muitos lugares com economias turísticas aquecidas, como na Colômbia, Costa Rica, Cuba e Venezuela, os afrodescendentes acabam obtendo boas remunerações em apenas duas atividades: prostituição e tráfico de drogas.

No Equador, os afrodescendentes têm a maior taxa de desemprego do país. (PUEBLOS INDÍGENAS Y AFRODESCENDIENTES DE AMÉRICA LATINA Y EL CARIBE, 2006, p. 435) Os afro-equatorianos que estão no mercado de trabalho, geralmente, são empregadas domésticas, seguranças, porteiros, motoristas ou trabalhadores temporários em setores da economia informal. (DE LA TORRE, 2005, p. 63) No Uruguai, a taxa de desemprego dos afrodescendentes é $50 \%$ maior que a taxa dos brancos, além de receberam apenas $60 \%$ do que os brancos ganham. (REID ANDREWS, 2010, p. 150) Mesmo onde a educação formal não é um pré-requisito, estudos latino-americanos mostram evidências de discriminação racial. Por exemplo, os afrodescendentes na liga nacional de futebol uruguaia têm sido alvo de discriminação racial.

Além do mais, o acesso de afrodescendentes à proteção do mercado de trabalho formal é altamente limitado. Por exemplo, na Colômbia, economistas observaram que, a despeito da existência de leis trabalhistas, a grande maioria das mulheres afrodescendentes que conseguiram trabalhar como empregadas domésticas, por 
meio das agências de emprego de Cali, é submetida a contratos abusivos que flagrantemente violam o direito do trabalho. (POSSO, 2008, p. 215-238) Além disso, embora as agências de emprego encaminhem muitas mulheres afrodescendentes para vagas no serviço doméstico, as agências raramente negociam contratos de trabalho escritos em nome das agenciadas. Pelo contrário, os contratos de trabalho são, em sua maioria, verbais, e oferecem menos proteções do que contratos unilaterais, que são a regra quando se fala em contratos escritos de emprego. (POSSO, 2008, p. 227) O estudo empírico do contexto do trabalho doméstico em Cali também aponta que, por causa do grande número de empregadores que preferem não contratar mulheres negras de pele escura, as mesmas recebem os piores salários e o menor nível de proteção trabalhista.

Dadas as batalhas que os afrodescendentes enfrentam na busca por trabalhos que possam lhes manter, não é surpresa que sua presença na esfera política também seja limitada. Vale ressaltar que a exclusão social de afrodescendentes, aparentemente, parece ser um problema insolúvel na América Latina por causa da exclusão simultânea da esfera política. De fato, um número significativo de países latino-americanos não permitiu que analfabetos votassem até quase um século depois da emancipação dos escravos. ${ }^{4}$ A capacidade de os afrodescendentes influenciarem políticas públicas que poderiam diminuir sua marginalização é reduzida porque os sistemas político e eleitoral excluem os afrodescendentes. Por exemplo, na Nicarágua, em 2007, não havia um único

4 Argentina: 1912 (eliminam-se os requisitos de alfabetização e propriedade); Bolívia: 1952 (eliminam-se os requisitos de alfabetização); Brasil: 1988 (eliminam-se os requisitos de alfabetização e propriedade); Chile: 1970 (eliminam-se os requisitos de alfabetização e propriedade); Colômbia: 1936 (eliminam-se os requisitos de alfabetização e propriedade); Costa Rica: 1913 (eliminam-se os requisitos de alfabetização), 1949 (eliminam-se os requisitos de alfabetização e propriedade); Cuba: 1901 (eliminam-se os requisitos de alfabetização); Equador: 1978 (eliminam-se os requisitos de alfabetização); El Salvador: 1945 (eliminam-se os requisitos de alfabetização); Guatemala: 1945 (eliminam-se os requisitos de alfabetização); Honduras: 1894 (eliminam-se os requisitos de alfabetização); Nicarágua: 1948 (eliminam-se os requisitos de alfabetização); Panamá: 1904 (eliminam-se os requisitos de alfabetização); Peru: 1979 (eliminam-se os requisitos de alfabetização e propriedade); Uruguai: 1918 (eliminam-se os requisitos de alfabetização e propriedade); Venezuela: 1946-1947 (eliminam-se os requisitos de alfabetização e propriedade). Engerman; Sokoloff, 2005, p. 912-913 (em que se analisa a eliminação de requisito de alfabetização na Argentina, Brasil, Chile, Colômbia, Costa Rica, Equador, El Salvador, Guatemala, México, Peru e Uruguai); Drake, Mccubins 1988, p. 134 (em que se analisa a eliminação do requisito de alfabetização na Argentina, Bolívia, Brasil, Chile, Colômbia, Costa Rica, Cuba, República Dominicana, Equador, Guatemala, Honduras, México, Nicarágua, Panamá, Paraguai, Peru e Venezuela); Bethell, 1998, p. 36 (em que se analisa a eliminação do requisito de alfabetização na Argentina, Brasil, Chile, Colômbia, Costa Rica, Peru, Uruguai e Venezuela). 
afrodescendente no Congresso Nacional, ainda que os afrodescendentes representem 9\% da população do país. (MÁRQUEZ et al., 2007, p. 27-28) Na Costa Rica, em 2006, não havia sequer um congressista negro dentre os 57 assentos disponíveis, também não havia nenhum ministro negro. (ESTADOS UNIDOS, 2007) Ainda que a afrodescendente costa-riquenha Epsy Campbell tenha tido uma participação histórica como candidata à presidência da república em maio de 2009, ela recebeu apenas 19\% dos votos. (MATA, 2009) Em contraste com o que ocorreu com os obstáculos à participação política decorrentes de gênero, a maioria dos governos latino-americanos não se preocupou ativamente com os obstáculos enfrentados pelos afrodescendentes. Em 2005, 11 das 18 nações latino-americanas tinham adotado cotas para aumentar a representação feminina em espaços de governo. (HTUN; JONES, 2002) Em média, a presença feminina no congresso aumentou em nove pontos percentuais nos países que adotaram as cotas de gênero. Todavia, a falta de intervenção estatal no que diz respeito aos afrodescendentes é um contraponto contundente.

Uma exceção recente é a Colômbia. Uma lei aprovada em 1993 garantiu a comunidades afrodescendentes o direito a ter dois representantes na Câmara dos Deputados conforme uma circunscrição eleitoral "virtual”, especialmente planejada para eles. Os efeitos da medida têm sido neutralizados pelo fato de que a cota para afro-colombianos representa apenas 1,2\% dos assentos no congresso, ao passo que se estima que os afro-colombianos representem um quarto da população colombiana.

A despeito da abundância de dados comprovando que a exclusão de afrodescendentes impregna a região, as elites latino-americanas atribuem a situação dos afrodescendentes exclusivamente às más condições socioeconômicas do grupo. Tal justificativa supõe que o padrão histórico de pobreza encontra-se divorciado da visão pejorativa de negritude. Além do mais, a abordagem limitada da situação de classe ignora o número crescente de estudos que demonstram que, quando a condição socioeconômica é isolada, as disparidades de raça continuam a existir na região, como discutido no capítulo que trata da segregação racial no mercado de trabalho.

O contexto brasileiro também permite estabelecer claramente que o preconceito racial é uma variável independente que influencia a marginalização dos afrodescendentes, fato comprovado por diversos estudos que levam em conta a situação de classe. Por essa razão, vale elaborar sobre a situação brasileira como estudo de caso. O Brasil serve como um exemplo particularmente útil porque, ainda que 
os afro-brasileiros constituam a maioria (ou pelo menos grande parte) da população, eles continuam relativamente ausentes das esferas de poder. Por conseguinte, a situação dos afrodescendentes em outros países, onde a população não é tão grande, é frequentemente mais penosa. Em outras palavras, a dimensão da influência do privilégio branco e do preconceito racial na marginalização de grande número de afrodescendentes no Brasil é um forte indício de que para todos os outros países, nos quais os afrodescendentes são menos numerosos e frequentemente menos poderosos politicamente, o padrão de exclusão racial do afro-brasileiro pode servir como uma representação útil de como o preconceito racial influencia a condição socioeconômica e a exclusão de afrodescendentes.

\section{O estudo de caso brasileiro}

Assim como no resto da América Latina, os indicadores socioeconômicos brasileiros mostram grandes desigualdades entre brasileiros brancos e negros, a despeito de os afrodescendentes representarem $51,1 \%$ da população nos dados do censo de 2009. (IBGE, 2010, tab. 8.1) Deve ser ressaltado que cientistas sociais brasileiros reúnem as categorias "preto" e "pardo" na mesma unidade de análise de "negro", para se antecipar às ambiguidades na autoclassificação racial dos indivíduos. Tal estratégia também se deve ao fato de que as desigualdades raciais prevalentes se concentram entre brancos e não brancos, e não entre pretos e pardos. Os brancos ganham, em média, o dobro do que os não brancos. (IBGE, 2010, tab. 8.6) Do mesmo modo, dados do Ministério da Saúde sugerem que existe uma nação dividida entre brancos e afrodescendentes. (ENTIDADES, 2008) Especificamente, a taxa de mortalidade infantil de crianças afro-brasileiras não é apenas maior historicamente, mas também piorou em 2000. (WOOD; CARAVALHO; HORTA, 2010, p. 114-139) As crianças afro-brasileiras possuem uma chance $44 \%$ maior de morrer de doenças infecciosas antes do primeiro ano de vida do que as crianças brancas. As crianças afro-brasileiras também têm $68 \%$ mais chances de morrer de tuberculose do que as crianças brancas. As taxas de mortalidade materna entre afro-brasileiras são $41 \%$ maiores que as taxas das mulheres brancas. As disparidades raciais são também prevalentes nas taxas de expectativa de vida, situação de moradia, acesso a bens duráveis e comunicação digital ${ }^{5}$

5 Fundo de Desenvolvimento das Nações Unidas para a Mulher e Secretaria Especial de Políticas para 
No Brasil, também há um padrão de segregação residencial. (TELLES, 1992, p. 186) Sendo que a segregação residencial por raça, no país, em termos estatísticos, não é tão grave quanto a segregação documentada nos Estados Unidos. As lideranças afro-brasileiras descrevem a segregação racial de fato existente no Brasil como algo comparável ao regime de apartheid sul-africano, no qual existem dois Brasis, um das exclusivas áreas brancas de hotel e outro das favelas e ruas majoritariamente negras. (MAROTTO, 2008; PITANGA; CROOK; JOHNSON, 1999, p. 31-32)

A maioria dos brasileiros vive em favelas, mocambos, palafitas etc. Visitar a estação Central do Brasil, no Rio de Janeiro, é testemunhar trens perigosamente dilapidados que levam horas para transportar, em sua maioria, trabalhadores negros da enorme região metropolitana (Baixada Fluminense) para seus empregos na cidade do Rio de Janeiro, uma cena que se assemelha à situação dos sul-africanos negros de cidades segregadas. O contraste racial entre uma escola pública da Baixada - ou nas periferias ou favelas de quase todo o Brasil - e uma universidade em uma área rica, como a zona sul do Rio de Janeiro, remete à diferença entre uma escola em um township e uma universidade na África do Sul. (NASCIMENTO, A.; NASCIMENTO, E. 2001, p. 108)

Ainda que a distância entre os bairros brasileiros de classe média e as favelas negras no Brasil seja menor que a distância, nos Estados Unidos, entre os bairros de classe média branca e os bairros negros, os bairros de classe média branca brasileiros estão isolados tanto psicológica como simbolicamente. A segregação opera-se pela construção de muros altos em condomínios fechados, os quais mantêm os afro-brasileiros fora do alcance da visão. (SHERIFF, 2001, p. 152) Além do mais, os afro-brasileiros que conseguem se integrar em uma área residencial branca, frequentemente, experimentam um alto grau de isolamento social e ostracismo. (TWINE, 1998, p. 26) Mesmo a noção mítica da celebração anual de um Carnaval integrado racialmente foi desmascarada por um pesquisador brasileiro, que observa:

Todos se juntam no maior carnaval do mundo, todos participam, 'cada um em seu lugar'. Não existe interação social entre os grupos, e as 
cordas marcam os limites físicos de cada grupo. Com vistas à afirmação dos negros no carnaval, as classes média e alta, autoidentificadas como brancas, reagem ao estabelecer rígidos critérios de discriminação social e racial para a participação em suas organizações. (BACELAR, 1999, p. 85,99$)$

A segregação no Carnaval é exacerbada pelos grandes números de brasileiros brancos que evacuam suas casas pelo período do Carnaval para evitar a desordem atribuída aos foliões negros. A segregação vai além da preocupação com a suposta criminalidade das favelas próximas, isso é verificado no modo pelo qual os brancos se organizam em mundos isolados com uma interação extremamente limitada com afro-brasileiros fora das relações hierárquicas empregado-serviçal. (SHERIFF, 2001, p. 151-161) “A realidade é que eles [os negros] não são normalmente incorporados em nossa vida, eles não estão em nossos círculos sociais”. (SHERIFF, 2001, p. 169) A vigilância para proteger os brancos da negritude é patente nas orientações dos pais para evitar interações com negros e com qualquer pessoa que possa ser percebida como negro depois de ficar um pouco bronzeado. "Ela (minha mãe) queria que eu ficasse bem branca, para mostrar que eu sou da raça ariana, certo? Para ficar branca, eu não ia à praia e assim eu não ficava escura como as outras pessoas". (SHERIFF, 2001, p. 163)

Os conjuntos habitacionais de baixa renda tampouco são lugares de inclusão multirracial. Por exemplo, estudos etnográficos em favelas brasileiras mostram que muitos brancos que vivem em favelas entre vizinhos negros conservam um senso de superioridade racial, refletido na declaração de um morador branco: "Eles são asquerosos. Eles são mal educados. Eu não gosto de pretos”. (SHERIFF, 2001, p. 132) O desdém pelos vizinhos afrodescendentes também é evidente quando os pais brancos se escandalizam quando seus filhos namoram vizinhos negros nas favelas: "Você está sujando a família". (SHERIFF, 2001, p. 138-139) Consequentemente, os moradores de favela acreditam piamente que ter pele mais clara e características europeias aumenta o potencial de sucesso e de uma vida melhor. (GOLDSTEIN, 2003, p. 108) Pesquisas em favelas indicam que afro-brasileiros encontram-se em relativa desvantagem se comparados aos moradores brancos, que têm maiores níveis de renda e menores índices de favelização. (VARGAS, 2006, p. 49-81) Isso é refletido nas disparidades raciais nas condições de vida da população afrodescendente, para a qual a falta de acesso a saneamento, coleta de lixo e água 
potável é maior que a falta de acesso que poderia ser apenas atribuída às diferenças regionais. (NASCIMENTO, 2007, p. 47)

O exame da disparidade racial brasileira no contexto educacional revela padrões assustadores. No Brasil, o analfabetismo entre a população não branca é mais que o dobro da taxa de analfabetismo entre a população branca. (NASCIMENTO, 2007, tab 8.2) Um estudo, que mantinha a renda familiar per capita constante, mostrou que: 1) não brancos têm menos anos de estudo do que brancos; 2) estudantes não brancos têm uma probabilidade maior de repetir a série do que estudantes brancos, e; 3 ) estudantes não brancos frequentam escolas que normalmente oferecem menos horas de aula do que escolas frequentados por estudantes brancos. (SILVA; HASENBALG, 1999, p. 53-54) ${ }^{6}$ Historicamente, estudantes de ascendência africana possuem níveis educacionais inferiores aos níveis alcançados por brancos da mesma faixa socioeconômica, e os ganhos educacionais dos estudantes de ascendência africana são desproporcionalmente mais baixos. (SILVA; HASENBALG, 1988 apud SILVA; HASENBALG, 1999, p. 54) Os brancos têm uma probabilidade muito maior de completar um curso universitário do que não brancos. Na década de 1990, havia uma possibilidade sete vezes maior de os brancos concluírem o ensino universitário. (SILVA; HASENBALG, 1999, p. 54-55) Mesmo com o advento das políticas de ação afirmativa nas universidades, atualmente, a taxa de admissão de brasileiros brancos continua sendo duas vezes maior que a de estudantes não brancos. (SILVA; HASENBALG, 1999, tab. 8.12)

Além do mais, à medida que a renda diminui, a diferença de acesso à educação entre estudantes de ascendência europeia e africana aumenta. (SILVA; HASENBALG, 1999, p. 53, 58) Claramente, as condições insatisfatórias de vida dos afro-brasileiros não podem ser atribuídas exclusivamente a uma questão de classe. A despeito das expectativas em contrário, o desenvolvimento econômico não corrigiu disparidades raciais no sistema educacional. (BROWN, 1999, p. 213-214) Alguns analistas chegam a sugerir que períodos de desenvolvimento socioeconômico nacional aumentaram a desigualdade racial ao invés de diminuí-la, especialmente para aqueles que estão nos extremos da estrutura social. (LOVELL, 2006, p. 81) Essa situação se torna ainda pior em razão das disparidades no acesso ao ensino universitário. (IBGE, 2008)

6 Em que se cita a pesquisa realizada pela Fundação Carlos Chagas em São Paulo, Brasil. 
As deficiências nos conteúdos da educação pública primária e secundária são ampliadas pelo tratamento racializado que as crianças recebem na escola. (SIMÃO, 2004, p. 85, 104) Por exemplo, cientistas sociais documentaram que a maioria dos professores brasileiros considera que estudantes afro-brasileiros têm baixo potencial de aprendizagem. (CHIARELLO, 2003, p. 50-53) A avaliação dos professores acerca do potencial e do desempenho dos estudantes é diretamente influenciada pela raça. (ROSSATO; GESSER; CAVALLEIRO, 2001, p. 11, 19) Como um professor declarou, "eles não conseguem aprender, não são disciplinados, são preguiçosos e desistem logo. Tudo que eles querem é sambar e jogar futebol. Está no sangue deles”. (NASCIMENTO, 2001, p. 509, 518) Mesmo estudos da Bahia, estado predominantemente negro, mostram que os agentes escolares consideram que os afrodescendentes apresentam baixa capacidade de aprendizagem. (REITER, 2009, p. 345-356)

As atitudes racializadas também são manifestadas nos livros didáticos usados pelas crianças, nos quais pessoas negras são reiteradamente retratadas como animalescas, socialmente subordinadas e de outras maneiras estereotipadas. (SILVA JUNIOR, 2002, p. 34-38) Por exemplo, quando crianças negras são alvo de comportamentos racistas dos colegas que internalizaram um preconceito social contra pessoas de pele escura, os professores e a direção das escolas consideram o comportamento uma piada ou uma provocação inofensiva. (SILVA JUNIOR, 2002) Essas atitudes racializadas podem, por sua vez, ajudar a explicar por que o governo negligencia a educação pública primária e secundária (PLANK, 1996, p. 6) e também pode ajudar a explicar por que especialistas em educação observam que no Brasil os "benefícios de programas 'universalmente' concebidos para melhorar os resultados educacionais não atingem os pobres adequadamente”. (WOLFF; CASTRO, 2000, p. 45, anexo 1)

Desse modo, no Brasil, as crianças de ascendência africana encontram não somente um ambiente hostil ao aprendizado, mas também um acesso racializado à educação. (BRAZIL'S UNFINISHED, 2000, p. 31) Por exemplo, ainda que seja obrigatório que as crianças entre sete e 14 anos estejam matriculadas em escolas (SILVA; HASENBALG, 1999, p. 55), é comum que famílias brasileiras que informalmente adotam crianças não brancas em troca de trabalho doméstico não assalariado dificultem a frequência escolar dessas crianças (TWINE, 1998, p. 37), além de ser comum as autoridades não fazerem cumprir a lei que torna essa frequência obrigatória. (PLANK, 1997, p. 1) Os estudantes afro-brasileiros que conseguem se manter na escola frequentemente encontram uma educação de segunda 
qualidade. (LARACH, 2001, p. 7) Por exemplo, na zona rural do Nordeste, onde a maioria dos habitantes são afrodescendentes, menos da metade dos professores de educação primária concluíram a educação primária. (PLANK, 1996, p. 7) Além do mais, mesmo as crianças da classe média afrodescendente cujos pais possuem condições de pagar a mensalidade, encontram barreiras para serem matriculadas em escolas particulares. Por exemplo, um relatório de 2008 relata a história de uma afro-brasileira, com formação universitária, que tentou matricular o filho de seis anos de idade em uma escola de elite em São Paulo. Na ocasião, outra mãe perguntou: "Você vê alguma outra criança negra aqui?”, como uma explicação para a rejeição da matrícula do seu filho. (MAROTTO, 2008)

A disparidade racial na educação básica resulta em um ambiente de segregação racial na universidade, uma vez que as escolas públicas de ensino fundamental e médio fracassam em preparar seus estudantes para o vestibular das universidades pública. (NASCIMENTO, A.; NASCIMENTO, E., 2001, p. 117) Como contraponto, os alunos brancos cujos pais tiveram mais condições de pagar por escolas particulares de ensino fundamental e médio de melhor qualidade estão mais bem preparados para o processo seletivo de universidades públicas. Como resultado, as universidades públicas e gratuitas são desproporcionalmente frequentadas por estudantes brancos. Por sua vez, as grandes companhias que recrutam preferencialmente estudantes de universidades públicas contam com uma equipe de trainees exclusivamente branca. (MAROTTO, 2008)

No Brasil, há um padrão sistemático pelo qual o investimento feito por afrodescendentes em educação resulta em menos oportunidades no mercado de trabalho que o investimento em educação feito por brasileiros brancos. (KILSZTAJN et al., 2005, p. 367-384) Mais especificamente, com apenas dois anos a mais de estudo, brasileiros brancos recebem em média 3,6 salários mínimos, enquanto os negros recebem 1,9 salário mínimo. (IBGE, 2006, tab 9.7) Quando afro-brasileiros e brasileiros brancos têm o mesmo número de anos de estudo, os brancos ganham $40 \%$ a mais que os negros. (IBGE, 2006) A desigualdade salarial existe mesmo entre os afro-brasileiros com o maior nível de educação e a disparidade é maior nos segmentos de maior renda. (NASCIMENTO, 2007, p. 46) De fato, o Instituto Brasileiro de Geografia e Estatística (IBGE) declara que a “educação não pode ser considerada um fator suficiente para superar as desigualdades raciais na renda dos brasileiros”. (IBGE, 2006, tab. 9.7)

A disparidade racial é tão prevalente no mercado de trabalho brasileiro que está arraigada nos mais diferentes setores. (BRAGA, 2005, p. 30) Até mesmo as 
práticas de contratação de atores de televisão refletem a exclusão e a hierarquia raciais com as quais os poucos afro-brasileiros contratados representam imagens estereotipadas e negativas de afro-brasileiros. (A NEGAÇÃO..., 2000) De modo similar, poucos modelos afrodescendentes são contratados para representar a beleza brasileira, a despeito da prevalência de pessoas de ascendência africana na população. (LUIZ, 2010) Mesmo no contexto da indicação de padres e bispos católicos, há estratificação racial, sendo que apenas 6,3\% dos padres no Brasil são afrodescendentes e apenas 2,5\% dos bispos católicos. (GOMES, 2007, p. 3) Como resultado das disparidades no mercado de trabalho, os afro-brasileiros representam 73\% dos miseráveis no Brasil e apenas 12\% dos mais ricos. Em contraste, brancos brasileiros representam apenas $12 \%$ da população miserável e $86 \%$ da população de maior renda. (IBGE, 2008, tab. 9.10) Portanto, não é surpreendente que as crianças afro-brasileiras sejam as maiores vítimas do trabalho infantil. (DUARTE, 2006)

A discriminação racial sistemática sugerida pelos dados apresentados ainda é agravada pelas numerosas situações de tratamento racializado no mercado de trabalho, nas escolas e em outros ambientes sociais. Por exemplo, entrevistas com trabalhadores afro-brasileiros revelam que a discriminação é um conjunto de práticas diárias manifestadas em todos os tipos de trabalhos, tanto em relação a empregados domésticos como em relação a profissionais. (BENTO, 1999, p. 109-122) Afro-brasileiros cujos resultados em testes de emprego os qualificam para posições administrativas são rotineiramente preteridos e lhes são oferecidas posições mais subalternas. (SHERIFF, 2001, p. 208-209) Um afro-brasileiro relata que, depois de ter sido aprovado para um emprego de vendedor, conforme os resultados de um teste, disseram-lhe que "não havia vagas para atendimento ao público, mas havia vagas para trabalhar no depósito do estoque. Mas ela sequer sabia meu nome; depois ela me perguntou 'Qual é o seu nome?' Ou seja, ela nem sequer olhou para o resultado da minha prova”. (SHERIFF, 2001, p. 208) Os afro-brasileiros são bem recebidos apenas como atendentes de caixa em grandes supermercados e lojas de departamento, posições que não lhes conferem status, além de serem bem aceitos como empregados domésticos, os quais, por sua vez, possuem baixo prestígio social. (BURDICK, 1998, p. 46-47) De fato, quando afro-brasileiros excepcionais conseguem acesso a bons cargos, estruturados em carreiras, em uma empresa, a discriminação racial aumenta. Devido ao desconforto de muitos colegas brancos em face da ascensão de afro-brasileiros a posições de poder, esses 
profissionais relatam que os colegas de trabalho procuram evitar trabalhar sob a autoridade de um negro, buscando orientação com outros superiores e procurando erros minúsculos no trabalho de afro-brasileiros. (BENTO, 1999, p. 115116) Não é surpreendente que o local de trabalho seja apontado como o lugar onde os afrodescendentes mais sofrem racismo. (SHERIFF, 2001, p. 86)

No entanto, a dor do racismo aparece também em outros contextos sociais. $\mathrm{Na}$ esfera pública, profissionais afro-brasileiros comumente relatam que, apesar de possuírem alto poder aquisitivo, costumam ser tratados com desdém. Quando são atendidos em restaurantes e lojas, o atendimento é ruim e, em especial, são lembrados de que "não pertencem àquele lugar... estão fora do lugar”. (FIGUEIREDO, 2010, p. 51-53; SILVA; REIS, 2011, p. 55-78) Ao passo que não existe uma política escrita de exclusão, ela é sistematicamente imposta. Por exemplo, um atleta afro-brasileiro foi expulso da piscina de um clube no Rio de Janeiro, na década de 1980, e um amigo explicou que, infelizmente, ele tinha chegado "durante o horário que os negros não podiam entrar na piscina". (SHERIFF, 2001, p. 207) Com mais frequência, os afro-brasileiros ficam sob suspeita quando entram em lojas. "As pessoas começam a encarar você, te dão o 'mau-olhado'. Não é nem por que elas pensam que você vai roubar alguma coisa, o que algumas vezes acontece. Mas é como se elas achassem que você é horrível ou algo assim, e que você não deveria estar lá”. (SHERIFF, 2001, p. 91)

Essa hipervigilância branca da negritude também ocorre em encontros sociais. Por exemplo, "quando uma pessoa escura chega em uma festa, as pessoas ficam olhando para ela. Uma festa na qual você foi convidado por outra pessoa, cheia de brancos, onde existem mais brancos. O pretinho que chega sempre sente que ele está sendo um pouco maltratado”. (SHERIFF, 2001, p. 92) De modo similar, quando há namoros inter-raciais entre brasileiros, não apenas provocam surpresa, mas também provocam censura e perseguição. (SHERIFF, 2001, p. 140)

As estruturas familiares também não estão livres do preconceito racial no Brasil nem no resto da América Latina. As crianças mais escuras em muitas famílias são frequentemente objeto de piadas e comentários raciais, enquanto os membros mais claros da família são considerados mais atraentes e inteligentes. (SHERIFF, 2001, p. 143-144) Etnógrafos afirmam não ser difícil encontrar narrativas sobre como a crianças de pele mais clara é conferido melhor tratamento. Por exemplo, em uma família com irmãs gêmeas, a garota mais escura era tratada como uma empregada da casa e a garota de pele mais clara era paparicada e tinha vários privilégios. (BURDICK, 1998, p. 43) 
Infelizmente, esse preconceito racial não é exclusivo da esfera privada. Vale ressaltar que a violência policial está impregnada desse preconceito. Por exemplo, a perseguição policial de afro-brasileiros é manifestada de um modo explicitamente racial, insultos raciais são ditos enquanto o abuso ocorre. (BURDICK, 1998, p. 94) Uma prática policial típica inclui entrar em ônibus urbanos e ordenar que jovens negros saiam do ônibus para serem revistados, tendo como única suspeita o fato de serem negros. Ademais, a extrema violência policial contra os negros conta com a aparente aprovação da população. (MITCHELL; WOOD, 1999, p. 1001-1020) Por exemplo, há registros de que a polícia do Rio de Janeiro sozinha mata 2,5 vezes mais pessoas por mês que a polícia de Nova Iorque mata em um ano, e a maioria das vítimas são afrodescendentes. (VARGAS, 2006, p. 56) Pesquisas com entrevistas estruturadas e grupos focais nas favelas do Rio de Janeiro indicam que a polícia associa negritude com criminalidade tão fortemente que, por ocasião das incursões nas favelas em que táticas policiais violentas são empregadas, as forças policiais não fazem nenhum esforço para distinguir os moradores que respeitam a lei dos criminosos. (INSTITUTO BRASILEIRO DE ANÁLISES SOCIAIS E ECONÔMICAS, 2007)

Essas atitudes racializadas permeiam também as instituições de aplicação do direito no Brasil. Em um estudo seminal das ações criminais por roubo, em 1993, na cidade de São Paulo, foi observado que quase o dobro de brancos foi libertado mediante o pagamento de fiança, quando comparado ao número de negros (27\% versus $15 \%$ ) na mesma situação. (ADORNO, 1995, p. 45-63) O estudo também mostrou que há disparidade racial nas taxas de condenações de brancos (59,4\%) e negros (68,8\%). Um estudo publicado em 2003 confirma a tendência de penalizar mais os afro-brasileiros, é o que demonstram as taxas desproporcionais de prisão e condenação entre brancos e negros. (LIMA; TEIXEIRA; SIGNORETTO, 2003, p. 3)

Experiências de racismo são prevalentes mesmo entre a classe média negra emergente. Em um estudo etnográfico de pessoas autodeclaradas negras na Pituba, um bairro de classe média em Salvador, $71 \%$ das pessoas afirmaram que haviam passado por situações de racismo. (SILVA, 2007, p. 75) O único ministro do Supremo Tribunal Federal negro, Joaquim Barbosa, declarou que, em comparação a suas viagens ao exterior para a Europa e os Estados Unidos, o Brasil é o lugar onde ele realmente teve experiências de discriminação racial. (VASCONCELOS, 2008) De fato, a condição de classe média não é um escudo contra a discriminação racial, pelo contrário, ser de classe média pode agravar a discriminação, 
uma vez que os afrodescendentes de classe média tentam entrar em espaços socialmente considerados exclusivos de brancos. (CALDWELL, 2007, p. 69) Por exemplo, um afro-brasileiro que trabalhou no mercado financeiro em São Paulo por 26 anos, exercendo a função de diretor de planejamento econômico e se vestindo como tal, relatou, em 2008, que sempre percebia que as mulheres brancas "seguravam a bolsa quando ele passava". (MAROTTO, 2008)

Uma análise da posição interseccional de gênero e raça da mulher afrodescendente deixa ainda mais claro o papel da raça na América Latina. (WADE; GIRALDO; VIGOYA, 2008) Os indicadores sociais para mulheres afrodescendentes na América Latina mostram uma situação devastadora de exclusão racial interseccional e preconceito. (SAFA, 2007) No Brasil, por exemplo, mulheres afro-brasileiras têm os piores indicadores socioeconômicos decorrentes das barreiras sociais na intersecção entre raça e gênero. (HERINGER, 2006, p. 142; LOVELL, 2000, p. 85-102) As estatísticas oficiais mais recentes revelam que as mulheres afro-brasileiras no mercado de trabalho estão em situação pior que as mulheres brancas e que os homens de todas as raças, pois elas estão desproporcionalmente super-representadas no mercado informal, portanto sem seguro-desemprego, licença-maternidade, entre outros. (IBGE, 2010, tab. 9.4) De fato, esse é o grupo mais marginalizado de toda a sociedade. (LUIZ, 2010) O salário médio das mulheres afro-brasileiras é metade do salário das mulheres brancas. (BENTO, 2004, p. 29) Mesmo quando as mulheres afro-brasileiras possuem o mesmo número de anos de estudo que as mulheres brancas, as brancas ganham $40 \%$ a mais que as mulheres negras. (BENTO, 2004) Além do mais, as brasileiras afrodescendentes têm as mais altas taxas de desemprego do país, a despeito de serem as primeiras a entrar no mercado de trabalho e as últimas a se aposentar. (BENTO, 2004) Análises das mudanças no mercado de trabalho durante períodos de rápida industrialização demonstram que proporcionalmente mulheres brancas ainda têm empregos mais bem remunerados e mais anos de estudo que mulheres negras. (LOVELL, 1999, p. 138, 149) Adicionalmente, mulheres brancas continuam a receber mais em todas as profissões. De fato, quando as diferenças socioeconômicas, como nível educacional e tipo de cargo ocupado, são controladas para fins estatísticos, percebe-se que as mulheres afro-brasileiras ganham menos que as mulheres brancas com qualificação similar. (LOVELL, 1999, p. 150) Além do mais, mulheres afro-brasileiras que ascendem ao topo de carreiras profissionais enfrentam desigualdades salariais ainda maiores. (LOVELL, 1999) 
Mesmo em São Paulo, a região economicamente mais dinâmica do país, a esmagadora maioria das brasileiras afrodescendentes permanece concentrada no nicho de empregadas domésticas e recebem menos que mulheres brancas e homens afrodescendentes em todos os níveis educacionais. (LOVELL, 2000) Além disso, a mobilidade ocupacional de mulheres afro-brasileiras em São Paulo é significativamente estacionária, em contraste com a mobilidade de mulheres brancas e homens negros. (TELLES, 2004, p. 143-144)

Para mulheres afro-brasileiras, a discriminação racial é veiculada frequentemente em forma de tratamento como objeto sexual, prostituta ou por meio da indicação da entrada de serviço com base na presunção de que são empregadas domésticas, a despeito do vestuário e adereços indicarem que elas fazem parte da classe média. (CALDWELL, 2007, p. xviii-xix) Elas também são excluídas de empregos por meio da exigência implícita e explícita de boa aparência, que quer dizer "aparência de branca". (CALDWELL, 2007, p. 66-67) Mesmo no contexto do setor de serviços domésticos, dominado pelas afro-brasileiras, as candidatas afrodescendentes acham que "eles preferem empregadas brancas em detrimento das empregadas negras”. (SHERIFF, 2001, p. 101) Os afro-brasileiros contratados como empregados domésticos relatam um padrão de comportamento por parte dos empregadores brancos que lhes designam pratos, utensílios e alimentos específicos, aparentemente motivados por um medo de contaminação racial. (SHERIFF, 2001, p. 102) De fato, a motivação racial dos empregadores é frequentemente bastante explícita, como demonstrada pelo seguinte comentário de um empregador: "Não, você não pode (trabalhar aqui). Não, meu marido não gosta de negros. Oh, eu não quero você (aqui), não, porque meus filhos não se dão bem com negras”. (SHERIFF, 2001, p. 103)

Em vez de contratar mulheres negras como empregadas, muitos empregadores brancos no Brasil e na América Latina preferem adotar informalmente jovens negras que possam fazer tarefas domésticas. Nessa prática de "pegar para criar”, uma espécie de adoção informal, famílias brasileiras de classe média e classe média alta recebem jovens afrodescendentes e cuidam delas em uma troca não declarada por trabalho não remunerado. Como uma mulher explica:

Eu precisava de uma empregada extra. Eu pedi para José Costa [...] para achar uma garota do interior, perto de Aliança. E, então, ele foi de carro para a vila na sua hora de almoço e bateu na porta de uma mulher para a qual ele tinha sido indicado. [...] Eu não a transformei em uma 
escrava como alguns ricos fazem com seus filhos de criação ou como nossas avós e bisavós tratavam seus filhos adotivos [...] Minha própria mãe manteve uma garota negra como uma espécie de escrava e, quando minha mãe morreu, eu a herdei como uma mulher de meia idade, uma adulta que parecia uma criança, que nunca havia casado e que não sabia fazer outra coisa que não cuidar da minha mãe. [...] Eu fiquei com ela até a morte dela. (TWINE, 1998, p. 35) ${ }^{7}$

Em contraste, no sistema formal de adoção, a maior parte das crianças negras definha em instituições porque elas não são desejadas por pais adotivos brancos, da mesma forma que os bebês afrodescendentes nos Estados Unidos são preteridos para adoção. (NUNES, 2008; WILLIAMS, 1994, p. 913-927) Com o sistema informal de adoção, "a criação", as tarefas não remuneradas de limpar, cozinhar e cuidar das crianças das famílias adotivas impõem uma rotina de trabalho que não permite que as garotas estudem. Quando uma dessas garotas foi questionada se, caso tivesse escolha, ela teria deixado a escola:

Não. Eu deixei a escola porque eu fui obrigada a deixá-la, entende? Eu tinha que trabalhar. Eu costumava cozinhar (para minha família de criação). E isso não me deixa tempo para a escola e para fazer as mesmas coisas (que minha irmã de criação). (TWINE, 1998, p. 43)

Portanto, não é surpreendente que as mulheres afro-brasileiras ostentem as maiores taxas de analfabetismo na população e não sejam bem atendidas pelo sistema precário de educação primária que, por sua vez, recebe, em sua maioria, crianças afro-brasileiras. (TELLES, 2004, p. 129-130) Mesmo o contexto de atenção à saúde revela a discriminação interseccional contra as mulheres brasileiras negras. Quando hospitalizadas para o parto, as afrodescendentes têm taxas muito mais altas de parto sem anestesia que as grávidas brancas $(21,8 \%$ e 13,5\%, respectivamente). (ALVES, 2006) Acredita-se também que mulheres afro-brasileiras são esterilizadas em maior proporção. (BURDICK, 1998, p. 2; CALDWELL, 2007, p. 163; WERNECK, 2004, p. 51-63)

Por conseguinte, uma grande quantidade de pesquisas qualitativas e quantitativas confirma que o Brasil, assim como o resto da América Latina, é uma sociedade racialmente estratificada na qual os afro-brasileiros experimentam

7 Em que se cita Nancy Scheper-Hughes. 
discriminação explícita e sutil, e mulheres afro-brasileiras sofrem um padrão de discriminação interseccional. De fato, a Organização dos Estados Americanos declarou que a arraigada discriminação racial no Brasil impedirá o país de atingir os Objetivos do Milênio, um conjunto de metas de desenvolvimento a serem alcançadas em 2015, estabelecidas na Organização das Nações Unidas, e que define maneiras mensuráveis de diminuir a exclusão social. (LOPES, 2006)

Em suma, um crescente número de estudos quantitativos e qualitativos sobre raça na América Latina desafia a noção culturalmente aceita de que raça não tem relevância social e econômica. (DULITZKY, 2005, p. 39-59) Todavia, as elites latino-americanas por muito tempo vêm apresentando a América Latina como moralmente superior aos Estados Unidos, uma vez que a região não contaria com uma segregação racial chancelada pelo Estado e, presumivelmente, não haveria nenhum outro indicador de discriminação racial. O legado do direito costumeiro de regulação racial no período pós-abolição na América Latina tem marginalizado os afrodescendentes social e economicamente. Ao mesmo tempo, as comparações estratégicas dos países latino-americanos com os Estados Unidos têm bloqueado a capacidade de desafiar a subordinação racial. Apesar disso, na tentativa de remediar a persistente desigualdade racial, movimentos de afrodescendentes que lutam por justiça social têm recorrido ao direito como uma arena de mudança na América Latina, um assunto que será explorado no próximo capítulo. 


\section{O movimento afrodescendente por justiça social e as novas leis antidiscriminação}

\section{A legislação antidiscriminação racial na América Latina}

Com a ascensão de governos democraticamente eleitos na década de 1990, os afrodescendentes enfrentaram menos oposição do Estado em relação à sua articulação em Organizações Não Governamentais (ONGs) e organizações comunitárias. Isso, por sua vez, gerou mais espaço para denunciar a má situação de vida e, portanto, muitas ONGs militantes em questões de raça começaram a se proliferar na América Latina. Por exemplo, na Venezuela, ativistas afrodescendentes organizaram o Congresso de Comunidades Afro-Venezuelanas. (REID ANDREWS, 2004, p. 195) Mesmo em Cuba, a despeito das restrições do governo em torno da mobilização política fora do Partido Comunista, uma nova organização negra, a Cofradía de la Negritud, foi formada em Havana, em 1999. Somente no Peru, existem pelo menos 15 organizações ligadas ao movimento social afro-peruano. (GOLASH-BOZA, 2011, p. 5) O "Apêndice A" desta obra oferece uma lista de muitas das organizações de afrodescendentes na América Latina.

Com o ativismo crescente, essas organizações foram capazes de obter importantes apoios políticos e financeiros de fundações estadunidenses e 
europeias comprometidas com a justiça racial, além de apoio de programas de inclusão social do Banco Interamericano de Desenvolvimento, da Fundação Ford e do Grupo Internacional de Direitos Humanos. Ao mesmo tempo, as organizações têm conseguido se comunicar com outras ONGs similares na região através da formação de redes e congressos regionais. Como resultado dessas colaborações internacionais, organizações de afrodescendentes têm conseguido articular suas perspectivas de forma mais potente em seu discurso público. (DIXON, 2008, p. 181-196)

A Conferência das Nações Unidas contra o Racismo, em 2001, e todos os encontros preparatórios que a precederam, foram particularmente importantes para galvanizar um grande número de organizações da sociedade civil para chamar a atenção pública para as mazelas da população afrodescendente na América Latina. Mais de 1.700 ativistas compareceram à conferência preparatória em Santiago do Chile, em 2000. Com a maior participação política das organizações da sociedade civil de afrodescendentes, uma imagem mais realista da situação da hierarquia racial na região começou a ser delineada. Como resultado da organização mais ampla da Diáspora Africana e a consequente atenção da mídia, começou a surgir uma pressão pública sobre os Estados e a atividade legislativa antidiscriminatória começou.

Ainda que seja possível legislar sobre várias formas de combater a discriminação em vários contextos - como no mercado de trabalho, no direito à moradia, nas eleições, em lugares de acesso público (incluindo em situações de consumo, bancos, serviços de educação, atenção à saúde e contratos do governo), entre outros -, a maioria dos países latino-americanos tem tido a tendência de se concentrar em algumas poucas áreas. A tipologia do "Apêndice B" desta obra, "Tipologia das medidas de antidiscriminação racial na América Latina”, exemplifica a variedade de leis antidiscriminação. Para começar, a maioria dos países latino-americanos, tradicionalmente, conta com dispositivos constitucionais genéricos sobre a igualdade, de modo a justificar que a desigualdade racial é abordada da maneira adequada. Um exemplo de dispositivo constitucional genérico com que todos os países latino-americanos contam, com variações, à exceção do Uruguai, é o trecho abaixo extraído da Constituição da Nicarágua: "Todas as pessoas são iguais perante a lei e têm o direito a igual proteção. Não haverá discriminação em razão de origem, nacionalidade, crença política, raça, sexo, língua, opinião, condição econômica ou posição social”. (NICARÁGUA, 1998) 
Além das provisões constitucionais genéricas sobre a igualdade, as medidas antidiscriminatórias abordam aspectos variados, entre os quais: o reconhecimento constitucional, a condição multirracial e multiétnica da população, a atribuição de direitos coletivos de propriedade para negros, como um grupo cultural distinto com laços históricos, para parcelas de terra específicas frequentemente colonizadas por grupos de escravos fugidos, os quilombolas, a imposição de sanções por discriminação racial que negam acesso a lugares públicos, a proibição de discriminação no mercado de trabalho, a obrigatoriedade de inclusão de conteúdo sobre afrodescendentes nos currículos escolares dos países, a proibição de disseminação de ideias baseadas em superioridade racial e a criminalização genérica da discriminação racial. O "Apêndice B" apresenta uma lista, por país, indicando onde essas várias medidas antidiscriminatórias foram adotadas.

\section{0 direito penal como cerne das leis antidiscriminação}

Apesar da ampla gama de medidas contra a discriminação racial, a grande maioria dos países da América Latina usa o direito penal como o meio para lidar com a discriminação racial. A razão desse enfoque está profundamente enraizada na imagem latino-americana de inocência racial. A partir da visão de que os países latino-americanos são racialmente inocentes, uma vez que não há, na América Latina, um histórico de segregação oficial no estilo da legislação Jim Crow americana, a abordagem jurídica dada ao racismo tem sido considerá-lo uma aberração em vez de uma parte sistêmica da cultura nacional. Como resultado, a resposta legal tem sido tratar o racismo como obra de indivíduos isolados, que supostamente possuem preconceitos anormais. Em suma, os racistas são criminosos e não representantes de normas culturais racistas arraigadas. Isso também ajuda a explicar por que a grande maioria das leis contra o discurso de ódio na América Latina faz parte dos códigos penais da região. Infelizmente, limitar a ideia a palavras preconceituosas proferidas pelas pessoas rotuladas como racistas despreza os aspectos estruturais e institucionais da discriminação, que se mantêm em operação mesmo na ausência de comentários racistas. Sobre a situação dos afro-equatorianos, o acadêmico Carlos de la Torre afirma que "Reduzir o racismo a palavras hostis e ações de indivíduos ignorantes, etnocêntricos e provincianos foi uma visão que dominou a sociologia americana até recentemente, mas tal postura não leva em consideração relações de poder”. (DE LA TORRE, 2005) 
Além do mais, alguns países da América Latina mantêm uma abordagem penal singular contra a discriminação. Por exemplo, na República Dominicana, a Lei Contra a Violência Intrafamiliar, de 1997, criminalizou o tratamento desigual e humilhante baseado em raça ou etnia. As pessoas condenadas pelo crime de discriminação podem ser presas por um ano e um mês e multadas em dois ou três salários mínimos. (REPÚBLICA DOMINICANA, 1997, par. III, art. 9) Na Nicarágua, o Código Criminal apena a obstrução de um direito constitucional por motivo de raça ou etnia. (NICARÁGUA, 2007, art. 427, 428) A pena é de seis meses a um ano de prisão. Se a obstrução racialmente motivada de um direito constitucional tiver sido feita publicamente, uma multa adicional pode ser imposta. O Código Criminal nicaraguense também autoriza o aumento da pena para outros crimes quando racialmente motivados. (NICARÁGUA, 2007, art. 36.5)

Ainda que a criminalização da discriminação racial sugira um forte compromisso normativo com a erradicação da discriminação, na prática, ironicamente, pode ter o efeito de tornar o sistema jurídico menos capaz de lidar com os problemas da desigualdade e discriminação. Casos criminais requerem um conjunto probatório mais robusto e um maior ônus da prova que casos civis. Por exemplo, uma análise das queixas peruanas no que diz respeito à experiência de apresentar uma demanda penal por discriminação racial demonstrou que o ônus da prova para casos de discriminação era alto e que, na maioria das vezes, era difícil para a vítima provar que sofreu discriminação. (PERU, 2007, p. 119) Um caso exemplar descrito no estudo é de uma pessoa que apresentou uma denúncia contra o departamento de polícia alegando ter recebido uma multa de trânsito injustamente por causa de sua raça. O promotor de justiça alegou que sua acusação não merecia uma investigação criminal ou persecução penal porque as provas apresentadas não eram suficientes: o querelante havia apresentado uma declaração juramentada sua e de um membro de sua família que havia testemunhado o incidente. É difícil imaginar o que mais o querelante poderia ter apresentado para fundamentar suas alegações. A demanda por mais elementos é assim emblemática da resistência latino-americana em aceitar a discriminação racial como objeto de uma ação penal viável.

Além da relutância de promotores em dar seguimento aos casos de discriminação racial, os magistrados também são relutantes em impor sanções penais. Os sistemas de justiça criminal latino-americanos são sobrecarregados com casos de crimes tradicionais contra a propriedade e crimes de violência 
contra a pessoa. Em um sistema marcado pelo grande volume desses crimes e pelas ineficiências sistêmicas, os crimes de racismo e discriminação racial têm e provavelmente continuarão a ter prioridade baixa.

Ademais, ao confiar a aplicação do direito penal a autoridades públicas, corre-se o risco de a lei ser menosprezada pela inação complacente dos agentes públicos que compartilham o mesmo preconceito racial que os autores da discriminação. De fato, analistas notam que agentes policiais latino-americanos são frequentemente autores de violência racial contra pessoas de ascendência africana, porque encaram sua função como a de proteger a sociedade de "maus elementos" por qualquer meio necessário, sem maior consideração ao Estado de Direito. (PINHEIRO, 1999, p. 1-16) Isso é particularmente perigoso na América Latina, onde é possível observar agentes policiais reiteradamente desencorajando afrodescendentes a registrar ocorrência de discriminação racial; ademais, os mesmos policiais são, frequentemente, autores de discriminação e violência. (BRINKS, 1999, p. 1001-1020)

O contraste entre os contextos cível e criminal é mais bem exemplificado pelo caso Tiririca, no qual o mesmo padrão de discurso de ódio produziu bons resultados na esfera cível, mas não na esfera penal. Francisco Everardo Oliveira Silva, cujo nome artístico é Tiririca, é um humorista brasileiro que lançou uma música, pela Sony Music, intitulada “Veja os cabelos dela”, em 1996. A música, essencialmente, é tirada contra o suposto cheiro ruim, animalesco, das mulheres negras e a feiura do cabelo naturalmente crespo. A letra dizia:

Quando ela passa, me chama atenção / Mas os seus cabelos, não têm jeito não / A sua catinga quase me desmaiou / Olha eu não aguento, é grande o seu fedor / Veja veja veja veja veja os cabelos dela / Veja veja veja veja veja os cabelos dela / Veja veja veja veja veja os cabelos dela / Veja veja veja veja veja os cabelos dela / Parece bom-bril, de ariá panela / Parece bom-bril, de ariá panela / Eu já mandei, ela se lavar / Mas ela teimou, e não quis me escutar / Essa nega fede, fede de lascar / Bicha fedorenta, fede mais que gambá. (CALDWELL, 2004, p. 18)

A ONG feminista negra Criola, juntamente com a ONG Centro de Articulação de Populações Marginalizadas (CEAP) e algumas outras organizações de defesa da justiça social, ajuizaram ações cível e penal contra o cantor e a gravadora. Na esfera penal, os autores moveram uma ação por racismo e perderam porque o juiz afirmou que não havia intenção de ofender as 
mulheres negras. (CUNHA, 1998) Na esfera penal, provar que houve discriminação não foi possível devido ao reduzido número de vezes que indivíduos declaram abertamente sua intenção de discriminar. Como resultado, a música continua em circulação.

Por outro lado, a ação civil foi bem-sucedida. A ação civil pública foi ajuizada sob a égide do artigo $3^{\circ}$ da Constituição, que declara ser objetivo nacional "promover o bem estar de todos sem preconceito de origem, raça, sexo, cor, idade e qualquer outra forma de discriminação”. (BRASIL, 1988, art. 3, par. IV $)^{1}$ A ação buscava proteger o direito coletivo de as mulheres negras serem livres de discriminação. Os direitos difusos são uma categoria de direitos que garante a um grupo de indivíduos com interesse comum, ainda que dispersos na comunidade política. (BRASIL, 1985, 1994, 2001) Longe do contexto penal, o qual requer a intenção de discriminar como suporte da ação, a vara cível alegou que a autoria da letra da canção por parte do réu era, por si só, discriminatória, porque as palavras utilizadas provocavam sentimentos de humilhação nas mulheres negras. (RIO DE JANEIRO, 2005) O juízo também levou em consideração que Tiririca era um humorista popular entre as crianças (que era frequentemente televisionado em rede nacional com roupas de palhaço) e que os comentários pejorativos da música são prejudiciais para a formação da juventude negra.

Como compensação pelos danos morais coletivos causados à dignidade, em 2008, o judiciário determinou o pagamento de 300 mil reais mais honorários advocatícios e custas processuais. (BANK OF CANADA, [200-]) Em 2012, o tribunal reformou a decisão para incluir valores retroativos à data do ajuizamento da ação, em 1997, aumentando assim o valor da condenação para 1,2 milhão de reais. Em sistemas romano-germânicos como o brasileiro, os danos morais são destinados a compensar os transtornos emocionais derivados do prejuízo à honra e à reputação de alguém. (LITVINOFF, 2004, p. 183, 208-211) Frequentemente, não se reconhecem danos morais para todos os tipos de ação de responsabilidade civil, mas somente àqueles que ofendem a dignidade. O pagamento em dinheiro pelo dano coletivo ao direito das mulheres negras foi pago ao Fundo de Defesa dos Direitos Difusos, administrado pelo Ministério da Justiça, para a criação de programas educacionais 
antirracistas para a juventude, a serem veiculados no rádio, televisão, filmes e material impresso para crianças do ensino fundamental no país.

O caso Tiririca mostra que, no contexto cível, a ausência de penas de prisão permite ao juiz considerar perspectivas modernas sobre igualdade racial ao decidir se a discriminação que tem sido historicamente prevalente na América Latina, mas invisível enquanto "cultura”, pode ser judicializável. A abordagem cível pode proporcionar teorias de discriminação mais gerais e critérios probatórios menos rigorosos. (RACUSEN, 2002, p. 87-88) Além disso, na área cível, há um menor risco de aplicação seletiva da lei, aplicação essa que atinge as populações vulneráveis desproporcionalmente. Isso porque, ao contrário da persecução criminal, o Estado não é o titular da ação. Todavia, em razão da noção dominante de que a lei penal contra a discriminação racial reflete a suposta seriedade com a qual o Estado encara o racismo, o desenvolvimento de medidas cíveis tem deixado a desejar e seu alcance tem sido limitado.

\section{O exemplo peruano do direito do trabalho e do consumidor}

No Peru, além do direito penal contra a discriminação (PERU, 2000), há várias leis não penais que proíbem a discriminação racial. A primeira lei, promulgada em 1997, proibia requisitos discriminatórios em ofertas de emprego e de acesso à educação. (PERU, 1997) Depois disso, a imprensa começou a tornar públicas as práticas discriminatórias nos clubes de dança de Lima, que reiteradamente negavam a entrada de afro-peruanos. (INTERNATIONAL DEVELOPMENT RESEARCH CENTRE, [200-]) O Instituto para a Livre Concorrência e Propriedade Intelectual (Indecopi), um organismo governamental para garantir a concorrência econômica aberta e justa e proteger os direitos de propriedade intelectual dos cidadãos (PERU, 1992), investigou e depois lançou uma campanha de pressão política contra as casas noturnas, em favor dos consumidores. (INTERNATIONAL DEVELOPMENT RESEARCH CENTRE, [200-]) Gravações de vídeo foram usadas no caso para provar que a discriminação racial foi a única razão pela qual alguns consumidores tiveram sua entrada negada. Em resposta ao clamor público decorrente dos incidentes, o Congresso aprovou uma segunda lei, a Lei $\mathrm{n}^{0} 27.049$, proibindo qualquer forma de discriminação racial pelos proprietários de estabelecimentos abertos ao público. Enquanto a lei é clara ao afirmar que a discriminação em estabelecimentos comerciais é proibida, o Congresso rejeitou a criação de uma ação processual diferenciada para as 
pessoas discriminadas. Em vez disso, os dispositivos da Lei no 27.270 são regulamentados pelo Decreto Supremo n ${ }^{\circ}$ 002-98-TR, o qual autoriza a Autoridade Administrativa Laboral a investigar atos discriminatórios, mas apenas após a apresentação de um pedido de investigação. (INTER-AMERICAN COMMISSION ON HUMAN RIGHTS, 2000)

Enquanto consumidores individuais podem reclamar junto ao Indecopi ou ao Serviço de Atendimento ao Cidadão (SAC), o processo, em si mesmo, apresenta problemas. Primeiro, o Indecopi cobra uma taxa por cada reclamação apresentada. (DENUNCIAS, [200-]) A taxa é um problema para os membros da comunidade afro-peruana, em grande maioria pobres. Segundo, a maioria dos cidadãos não sabe como dar seguimento ao processo, e há muitas reclamações por tratamento rude e péssimos serviços prestados pelos agentes oficiais. (VEGA, 2006) Terceiro, o Indecopi não tem escritórios espalhados pelo país, tornando a tarefa de iniciar o processo, e acompanhá-lo, difícil.

Para um processo ser bem-sucedido na área do direito do consumidor, o autor tem o ônus de provar o tratamento diferenciado recebido, ao passo que o proprietário deve mostrar que suas ações foram objetivas e justificadas. Caso reste provada a idoneidade do proprietário, o consumidor deve arcar com o ônus de provar que a justificativa do proprietário é um pretexto para discriminá-lo racialmente. Esse processo se assemelha ao modelo estadunidense de provar a discriminação, conforme o título VII da Lei de Direitos Civis de 1964. Portanto, torna-se muito difícil provar à agência de proteção ao consumidor que a pessoa foi discriminada na condição de consumidor. Ainda que essa seja uma reclamação popular, alguns têm apontado que há exigências aplicadas arbitrariamente pelos oficiais da agência de proteção ao consumidor que impedem pessoas de apresentarem uma reclamação. Uma dessas exigências é mostrar um comprovante do lugar em que a pessoa sofreu discriminação. Esse requisito é particularmente surpreendente, uma vez que o ponto crucial da reclamação é que a pessoa teve sua entrada ao estabelecimento negada e, portanto, não poderia consumir algo que pudesse usar para obter um comprovante fiscal. Outro problema na aplicação das leis de proteção ao consumidor é concentrar-se no acesso do consumidor a locais de entretenimento, em vez de enfocar o tratamento não discriminatório em unidades de atendimento à saúde. Essa é uma omissão significativa, uma vez que os serviços de atenção à saúde foram considerados a esfera em que a discriminação racial é mais predominante, segundo um estudo sobre o racismo no Peru. (PLANAS; VALDIVIA, 2009, p. 35) 
Há também uma tendência crescente entre os proprietários de certos estabelecimentos que, para burlar as leis antidiscriminação, alegam que operam negócios que atendem exclusivamente turistas norte-americanos e europeus, os quais supostamente preferem contratar um setor de serviços que empregue apenas brancos. (VEGA, 2006) Particularmente em grandes cidades como Lima, empresários que usam a estratégia do "somente turistas" têm sido bem-sucedidos não apenas em excluir afro-peruanos, mas também em evitar terem suas práticas discriminatórias detectadas. (APRODEH, 2005)

O contexto das relações de trabalho apresenta desafios de aplicação similares. O Ministro do Trabalho e Promoção do Emprego (MTPE) é o encarregado de investigar alegações de discriminação. (ESTADOS UNIDOS, 2007) Para começar esse processo, é necessário levar uma reclamação ao conhecimento do MTPE; se for constatado que a parte acusada publicou um anúncio discriminatório, então ela será multada. Essa lei também obriga os veículos da mídia a levar ao conhecimento das autoridades peruanas tais anúncios discriminatórios e a colaborar na investigação dos casos. Um empreendimento que violar a lei pode ser fechado por um período inferior a um ano. Uma vítima de discriminação também pode acionar judicialmente um empregador pela violação da Lei $\mathrm{n}^{\mathrm{o}}$ 26.772, por meio de uma vara trabalhista ou através do Tribunal Constitucional, para casos envolvendo direitos previstos na Constituição. (ESTADOS UNIDOS, 2007)

Em casos de oferta de emprego, as regras do MTPE permitem aos empregadores fazer algumas exigências que poderiam ser consideradas discriminatórias se eles puderem demostrar uma "justificativa razoável e objetiva", ou seja, se as exigências estiverem relacionadas à qualificação necessária para o emprego. (VEGA, 2009) Então, por exemplo, uma exigência racial poderia ser supostamente admitida para a contratação de um ator para interpretar um papel racialmente específico, do mesmo modo que, nos Estados Unidos, o título VII prevê uma exceção à proibição de usar a origem nacional como requisito para contratação (mas proíbe exigências com base em raça para relações de emprego). (RUTHERGLEN, 2010, p. 129)

Essa lei, entretanto, não trata adequadamente o problema dos anúncios discriminatórios, e ainda é comum encontrar empregadores lançando mão da expressão "boa aparência" (buena aparencia) como requisito, um eufemismo bastante conhecido para descrever uma pessoa com fenótipo branco. Todavia, o MTPE informou que entre 1998 e 2006 apenas 14 reclamações foram feitas, e 
seis das reclamações foram resolvidas. (PERU, 2007, p. 205) Em 2010, o MTPE recebeu 28 reclamações e multou três empresas infratoras. Depois disso, o Ministério do Trabalho reeditou o esforço para combater esse tipo de anúncio de emprego discriminatório e prometeu reforçar o cumprimento. (PROGRAMA NACIONAL DE EMPLEO JUVENIL, 2010) Concretamente, o MTPE anunciou que implementaria um sistema integral para administrar as reclamações dos candidatos a emprego que acreditam terem sofrido discriminação. Esse novo sistema permitiria indivíduos a apresentar reclamações por escrito, por telefone ou pela internet.

A discriminação no mercado de trabalho, durante a relação de emprego, é proibida tanto pela Constituição peruana como pela Lei de Produtividade no Trabalho. (PERU, 1997) Segundo essa lei, um juiz pode determinar medidas que impeçam a discriminação e multar o empregador. Se o empregado quiser rescindir o contrato de trabalho por causa de práticas discriminatórias, o empregado pode ser indenizado. Essa lei também invalida a extinção do contrato por motivo discriminatório. Conforme essa lei, se o juízo determinar que a reclamação tem fundamento, o trabalhador pode ser reintegrado ao trabalho ou optar pela indenização.

Todavia, é provável que a capacidade de as leis trabalhistas reformadas lidarem de forma eficaz com a discriminação racial seja dificultada pela contínua ambivalência do governo nas situações em que é preciso lidar diretamente com as necessidades da população afro-peruana. Por exemplo, o governo se desculpou oficialmente, em 2009, na forma de uma resolução estatal, expressando "arrependimento histórico à população afro-peruana pelos abusos, exclusão e discriminação cometidos contra os mesmos no período colonial e no presente”. (PERU, 2009) Contudo, durante a cerimônia oficial em que o presidente anunciou o pedido de desculpas em nome do Estado, ele afirmou que as desculpas seriam capazes de "limpar o Estado e a História de tal culpa". (ALAN GARCÍA, 2009) Ficou a impressão de que o presidente García considera que os danos contra seus afrodescendentes são suficientemente pequenos para serem solucionados com um simples pedido público de desculpas. Desse modo, temos mais um exemplo de como a comparação implícita da questão racial na América Latina com o "racismo verdadeiro" dos Estados Unidos ainda situa o Peru como um inocente racial, um herdeiro passivo do racismo colonial espanhol e um país em que a falta de uma segregação no estilo Jim Crow isentaria o Estado de tomar qualquer ação direta para remediar a discriminação. Portanto, 
será difícil promover reformas legais mais efetivas contra a discriminação, com um governo confiante de que um pedido de desculpas formal é o bastante para corrigir os danos causados. Ao mesmo tempo, dada a luta afro-peruana contra a invisibilidade no seu próprio país, o reconhecimento da existência de afro- peruanos e da discriminação contra o grupo, feito por ocasião do pedido de desculpas, pode ajudar a impulsionar os esforços da comunidade afro-peruana em defesa dos direitos civis.

\section{O exemplo colombiano de constituições multiculturais, o direito à terra e a reforma curricular}

A Constituição Colombiana de 1991 reconhece e protege a diversidade cultural e étnica da nação. (COLÔMBIA, 1995, art. 7) Dessa maneira, a Colômbia se juntou a vários outros países latino-americanos, como Bolívia, Equador, Guatemala, México, Nicarágua, Paraguai e Venezuela, no reconhecimento constitucional do caráter multicultural e multiétnico da nação. Existem diversas definições sobre em que consiste uma constituição "multicultural”. Os cientistas políticos discutem o conceito de multicultural como uma cidadania diferenciada, ao passo que os juristas geralmente divergem e consideram o conceito como o constitucionalismo de um Estado multicultural. (CARLSON, 2002, p. 1470-1487) Neste trabalho, eu caracterizo uma constituição multicultural como aquela em que o texto explicitamente se refere à importância da proteção por parte do Estado à diversidade étnica e cultural da nação ou aquela que reconhece a nação como multiétnica e busca facilitar políticas de inclusão. (MALDONADO, 2006)

Contudo, nem todas as constituições multiculturais situam as comunidades afrodescendentes da mesma forma. Juliet Hooker chama atenção ao fato de que os Estados latino-americanos têm primeiramente concebido os direitos multiculturais como pertencentes a povos indígenas, que são vistos como merecedores da condição de membros de grupos "étnicos", por outro lado, os afrodescendentes têm sido frequentemente excluídos da condição de sujeitos "raciais" distintos, fazendo com que sua identidade étnica não mereça proteção constitucional. (HOOKER, 2009, p. 80-82) A dicotomia feita entre povos indígenas dignos de reconhecimento "étnico" e afrodescendentes não dignos de reconhecimento "racial” ignora a racialização dos povos indígenas, assim como as identidades culturais das comunidades afrodescendentes. Por essa razão, a 
Colômbia se destaca por ter sido um país que incluiu os afrodescendentes, ao mesmo tempo que exemplifica as limitações de uma nação em equiparar direitos multiculturais com a condição de grupo étnico. Desse modo, a Colômbia contrasta exemplarmente com países como México e Venezuela, que excluíram completamente os afrodescendentes de seu panorama de direitos multiculturais. A Colômbia também contrasta com aqueles países que reconheceram aos afrodescendentes os mesmos direitos coletivos à terra e à cultura, tais como Guatemala, Honduras e Nicarágua. Juliet Hooker caracteriza a Colômbia, o Brasil, o Equador e o Peru como países onde afrodescendentes obtiveram alguns direitos constitucionais multiculturais, mas não na mesma extensão que os obtidos pelas comunidades indígenas.

A Constituição colombiana declara que "reconhece e protege a diversidade cultural e étnica da nação colombiana”. (COLÔMBIA, 1995, art. 7) O artigo transitório 55 da Constituição de 1991 determina que leis que reconheçam o direito dos afrodescendentes à propriedade coletiva da terra sejam aprovadas. Assim, as provisões constitucionais foram intensificadas por legislação infraconstitucional. Como forma de implementar o mandamento constitucional do artigo 55, foi aprovada em 1993 a Lei ${ }^{\circ}$ 70, para proteger os direitos de afro-colombianos à propriedade da terra. A lei prevê a eleição de líderes que representem as comunidades em questões relativas à terra e a outros assuntos mediante um sistema de consulta prévia. $\mathrm{O}$ artigo $7^{\circ}$ da Lei $\mathrm{n}^{\circ} 70$ dispõe que os títulos coletivos de terra são inalienáveis, não passíveis de execução e imprescritíveis. Entretanto, essa lei se limita à área da Costa do Pacífico e outras zonas especificamente delimitadas. (THE BERNARD AND AUDRE CENTER FOR HUMAN RIGHTS AND JUSTICE, 2007, p. 8) Outras áreas explicitamente não incluídas nas provisões legais são áreas urbanas, territórios indígenas, áreas de parques nacionais e áreas reservadas para segurança e defesa nacional. O que isso efetivamente significa é que um grande número de afrodescendentes urbanos, fora da Costa do Pacífico, estão excluídos da proteção constitucional porque eles não são considerados vinculados às parcelas específicas de terra, diferentemente das comunidades indígenas com seus títulos coletivos de terra. A Lei $\mathrm{n}^{\circ} 70$, então, apenas lida com as necessidades de um segmento da população afro-colombiana.

E mesmo os afro-colombianos que podem pleitear a titularidade da terra nos moldes da Lei $\mathrm{n}^{\circ} 70$ têm obtido apenas resultados modestos. Isso porque as ações são prolongadas, pois dependem de estudos técnicos sobre as terras. 
Além disso, a Lei 70 requer que apenas terras consideradas devolutas (terras baldías) possam ser apropriadas como propriedade coletiva. Considerando que os afro-colombianos são regionalmente e etnicamente diversos, os povos não vivem na mesma terra (de fato, alguns afro-colombianos não usam sequer o espanhol como língua nativa. Os raizales são um grupo étnico que fala uma espécie de língua crioula que mistura inglês afro-caribenho). Além disso, o processo de titulação da terra é especialmente exigente porque requer a produção de estudos históricos, demográficos, econômicos e cartográficos da comunidade que reivindica a propriedade coletiva da terra.

Do mesmo modo, muitos afro-colombianos têm sido dissuadidos de iniciar o processo de titulação das terras pela violência de grupos paramilitares e pelo exército colombiano. (AROCHA, 1998, p. 70-89) Os organizadores de comunidades afro-colombianas que buscam a propriedade coletiva têm sido considerados guerrilheiros e terroristas e, portanto, têm sido alvo de violência pelo governo interessado em controlar as áreas afro-colombianas ricas em recursos naturais em favor do desenvolvimento empresarial. (ASHER, 2009) Adicionalmente, grupos paramilitares de direita, há muito envolvidos com tráfico de drogas, também estão envolvidos em ações para se apossar da terra. (ROSERO, 2002, p. 547-559) Com isso, há pelo menos um estudo com informação de que $33 \%$ dos afro-colombianos foram expulsos de suas próprias terras por grupos armados. (GLOBAL RIGHTS PARTNERS FOR JUSTICE, [200-]) Dentre as pessoas expulsas de suas terras por causa da guerra civil, o mais alto percentual é o de afro-colombianos. (CONSULTORÍA PARA LOS DERECHOS HUMANOS Y EL DESPLAZAMIENTO, 2008; CONSULTORÍA PARA LOS DERECHOS HUMANOS Y EL DESPLAZAMIENTO, [200-]) Ademais, um afro-colombiano tem $84 \%$ mais chances de perder suas terras do que um mestiço. Apenas em 2007, dentre a população colombiana com registro de propriedade coletiva de terras, $79 \%$ foram expulsos de suas terras. (GARAVITO; SIERRA; ADARVE, 2008, p. 34-35) A expulsão dos afro-colombianos (e o de comunidades indígenas também) de suas terras é tão significativa que, em 1999, as Nações Unidas oficialmente advertiram o governo colombiano para lidar com essa forma de discriminação racial. (UNITED NATIONS HIGH COMMISSION FOR HUMAN RIGHTS, 1999) Depois disso, a Corte Constitucional da Colômbia avaliou a política de governo para tratar da situação dos desabrigados e estabeleceu que a política era inadequada e inconstitucional por violar direitos fundamentais de cidadãos colombianos. (COLÔMBIA, 2004) Desde então, 
conforme ordem da corte, o governo tem sido obrigado a criar políticas para prevenir a remoção forçada de proprietários de terras, além de mitigar as más condições de vida dos expulsos das suas terras. Infelizmente, as deliberações do governo, no que diz respeito às necessidades dos expulsos, não têm enfocado no impacto particular sobre os afro-colombianos como um grupo. (MARTÍNEZ, 2006, p. 42-47) $)^{2}$

Por outro lado, o governo tem se mostrado disposto a considerar os afro-colombianos como um grupo, no que diz respeito à reforma educacional. Em 1998, o presidente Álvaro Uribe aprovou um decreto presidencial ordenando que as escolas ensinem história e cultura afro-colombianas. (COLÔMBIA, 1998) O artigo 160 da Lei 115 dispõe que a diretoria educacional de cada distrito deve incluir um membro representando a comunidade afro-colombiana local, se tal comunidade local existir. (COLÔMBIA, 1994, art. 160, \$10) Espera-se que com a maior exposição educacional às contribuições dos afro-colombianos à sociedade colombiana, uma verdadeira igualdade racial se tornará desejável para toda a população.

Contudo, a promessa das constituições multiculturais precisará confrontar a longa e arraigada história de políticas racialmente excludentes na América Latina. Por exemplo, ao implementar a legislação de "proteção multicultural”, como requer a Constituição, as autoridades governamentais devem consultar as comunidades afrodescendentes antes de tomar decisões que afetem as terras das comunidades. Os afro-colombianos enfrentam barreiras para o processo de consulta porque o governo deve, primeiro, oficialmente, reconhecer um "conselho comunitário" de afrodescendentes preestabelecido, antes de os afrodescendentes terem o direito de serem consultados. O processo de reconhecimento oficial tem sido visto como excessivamente burocrático e limitante. Todavia, depois de tantos anos de marginalização, mesmo o reconhecimento constitucional simbólico da importância dos afrodescendentes constitui por si só um sinal de progresso. (VAN COTT, 2000) Uma alternativa às constituições multiculturais tem sido a tentativa brasileira de aprovar leis contra a discriminação com uma abordagem integral.

2 Ao fazer uma busca na internet sobre esse artigo, porque me parecia que na versão consultada faltavam algumas palavras, descobri que seu autor é Luis Gerardo Martínez Miranda e o artigo se intitula "Desde adentro: una aproximación al tema de Verdad, Justicia y Reparación a partir de las víctimas afrocolombianas". 


\section{O exemplo brasileiro de luta por um sistema jurídico antidiscriminatório integral}

Devido aos grandes avanços feitos pelo Brasil no que diz respeito à criação e à aplicação de leis antidiscriminatórias, seu contexto se torna merecedor de atenção especial. A concentração de esforços para usar o direito como veículo de mudança social é particularmente significativa devido à histórica exigência de ser alfabetizado para poder votar. (MARX, 1998, p. 258) Por causa dessa exigência, que perdurou até 1985 e que efetivamente excluía a maioria da população afro-brasileira, a arena política não foi o espaço mais promissor para a mudança social. Assim, a moderna legislação brasileira de direitos civis só começou em 1951, com a aprovação da Lei Afonso Arinos. (BRASIL, 1951) A lei criminalizou a discriminação racial no mercado de trabalho, no comércio, em espaços públicos, no governo e na educação. A discriminação nessas áreas foi declarada crime punido com prisão e multa.

A lei introduziu o que se tornou um padrão na legislação de direitos civis brasileira: tratar a discriminação racial como ofensa penal. Como resultado, a legislação antidiscriminação, historicamente, tem sido subaplicada e, portanto, ineficaz. De fato, a Lei Afonso Arinos é largamente aceita como um mero gesto de relações públicas voltado a mitigar a má impressão deixada quando uma dançarina estadunidense, Katherine Dunham, foi barrada em um renomado hotel brasileiro e, portanto, teria sido a lei decorrente da influência do poder industrial e comercial estadunidense (e não por causa do racismo brasileiro). (TELLES, 2004, p. 38) Consequentemente, a Lei Afonso Arinos não reconheceu o racismo no Brasil, nem procurou remediá-lo, a despeito do fato de ativistas afro-brasileiros em defesa da justiça social terem chamado a atenção do público e da imprensa para o incidente com Katherine Dunham. A lei aprovada era uma versão mais amena de um projeto de lei antidiscriminatória que ativistas afro-brasileiros apresentaram para aprovação. (NASCIMENTO, 2007, p. 148-149)

Apenas nove réus foram condenados nos primeiros 46 anos que se seguiram à aprovação da lei em 1951. (CESAR, 2003, p. 212-213) Durante a ditadura militar brasileira (1964-1986), leis antidiscriminação continuaram a não ser aplicadas e não foram levadas seriamente pelos atores governamentais. Consequentemente, os esforços atuais para usar a arena legal como veículo de transformação social no país ocorrem tendo como pano de fundo algumas leis de direitos civis anteriores, consideradas ineficazes. 
Cada uma das constituições brasileiras resguardou o princípio da igualdade formal perante a lei. Com o retorno à democracia, a atual Constituição de 1988 incluiu várias cláusulas relacionadas à discriminação racial, as quais ativistas sociais conseguiram incluir como parte de uma ampla reforma pós-ditadura militar em 1986. (BRASIL, 1988, art. 5, sec. XLII) No título I, "Dos Princípios Fundamentais", a Constituição estabelece que uma das bases do Estado Democrático de Direito é "promover o bem de todos, sem preconceitos de origem, raça, sexo, cor, idade e quaisquer outras formas de discriminação" (art. $3^{\circ}$, IV). O mesmo título estabelece que o Brasil é regido, nas suas relações internacionais, pelo princípio de repúdio ao terrorismo e ao racismo (art. $4^{\circ}$, VIII).

Por sua vez, o título II da Constituição Federal, que se refere aos direitos e às garantias fundamentais, estabelece no artigo $5^{\circ}$, caput, a igualdade de todos perante a lei e, no artigo 42, que "a prática do racismo constitui crime inafiançável e imprescritível, sujeito à pena de reclusão, nos termos da lei”.

Ademais, o artigo 215, em seu parágrafo $1^{\circ}$, estabelece que "O Estado protegerá as manifestações das culturas popular, indígena e afro-brasileiras, e das de outros grupos participantes do processo civilizatório nacional”. O artigo 216, parágrafo $5^{\circ}$, dispõe que "Ficam tombados todos os documentos e os sítios detentores de reminiscências históricas dos antigos quilombos". Por fim, o artigo 68 do Ato das Disposições Constitucionais Transitórias reconhece aos remanescentes das comunidades dos quilombos, que estejam ocupando suas terras, a propriedade definitiva, devendo o Estado lhes conferir os títulos respectivos. Contudo, em maio de 2008, apenas 87 dos 3.550 quilombos atualmente reconhecidos pelo governo brasileiro receberam seus títulos de terra. (BETWEEN, 2008)

Logo, após a promulgação da Constituição de 1988, leis de direitos civis foram aprovadas. Um ano após a promulgação da Constituição, o Congresso aprovou a Lei ${ }^{0}$ 7.716, que criminaliza a discriminação baseada em raça ou cor em lugares públicos, no mercado de trabalho e no setor privado. (BRASIL, 1989) A lei, conhecida como Lei Caó, era extensa, e muitas críticas foram feitas no sentido de que as disposições eram vagas e continham muitas brechas. (SILVA; SFOGGIA, 1997, p. 11-28) Em seu texto original, a lei criminalizou uma série de ações que são resultantes do preconceito de raça ou cor, incluindo impedir ou obstar o acesso de alguém, devidamente habilitado, a qualquer cargo da administração direta ou indireta, bem como das concessionárias de serviços públicos; negar ou obstar emprego em empresa privada; recusar ou impedir acesso 
a estabelecimentos comerciais em geral, negando-se a servir, atender ou receber cliente; ou comportamentos similares em hotéis, restaurantes, transporte público, arenas esportivas, salões de beleza; impedir acesso a prédios ou elevadores; impedir acesso às forças armadas, estabelecimentos educacionais; e impedir ou bloquear, de qualquer maneira, casamento ou convivência familiar. A Lei Caó é mais extensa e específica que a Lei Afonso Arinos de 1951, e as punições variam entre um e cinco anos de prisão.

Em 1990, a Lei $n^{\circ} 8.081$ modificou a Lei ${ }^{\circ} 7.716$, aprovada no ano anterior, incluindo o tipo penal "praticar, induzir ou incitar, pelos meios de comunicação social ou por publicação de qualquer natureza, a discriminação ou preconceito de raça, por religião, etnia ou procedência nacional”, com pena variando entre dois e cinco anos de prisão. (BRASIL, 1990)

A Lei Paim alterou a Lei Caó, em 1997, ao especificar que qualquer crime com base em raça, etnia, religião, cor ou origem nacional poderia ser punido com pena de um a três anos de prisão e multa. (BRASIL, 1997) As modificações foram principalmente processuais, reduzindo a pena para o crime de expressões racistas para de um a três anos de prisão e alterando a definição de crimes contra a honra ao incluir o crime de injúria racial. (BRASIL, 1940, art. 140, $\S 3^{\circ}$ ) O insulto racial difere do crime de racismo porque pune o dano contra a dignidade individual. Já o crime de racismo apena o dano causado a um número indeterminado de pessoas da mesma raça ou cor. Por essa razão, ao contrário do crime de dano individual de insulto racial, o crime de racismo, que afeta uma coletividade, não está sujeito à prescrição e é inafiançável. Nos casos de insulto racial, o juiz pode, discricionariamente, suspender a aplicação da pena de um a três anos, e há um período prescricional de oito anos. (MEYER-PFLUG, 2009, p. 102-103)

$\mathrm{Na}$ esfera cível, a regra geral de Direito Civil de responsabilidade por danos morais pode ser aplicada em casos de discriminação racial (os danos morais compensam o prejuízo causado pelo sofrimento psíquico ou o transtorno emocional, pelo dano à honra ou reputação). $\mathrm{O}$ artigo $5^{\circ}$ da Constituição Federal prevê indenização por danos materiais, morais ou à imagem. Além disso, o artigo 186 c/c 927 do Código Civil diz que aquele que, por ação ou omissão voluntária, negligência ou imprudência, violar direito e causar dano a outrem, ainda que exclusivamente moral, comete ato ilícito e fica obrigado a repará-lo.

A despeito da grande variedade de leis antidiscriminação, são poucas as questões levadas ao judiciário, apesar da existência de delegacias de polícia 
específicas para investigar e aplicar tais regras. (INTER-AMERICAN COMMISSION ON HUMAN RIGHTS, 1997) As pesquisas têm mostrado que apenas uma pequena porcentagem dos casos de discriminação chega às instâncias mais altas e que as ocorrências são frequentemente rechaçadas pelos agentes policiais. Uma pesquisadora brasileira sugere a tese de que o sistema legal tende a tratar o racismo e a discriminação como casos raros e isolados e não como parte de um padrão social mais amplo. (MARINHO, 1999) De tal modo, muitos advogados e defensores dos direitos civis têm apontado ambiguidades legais e a recusa das instâncias superiores de julgar esses casos.

Ao analisar a legislação antidiscriminação brasileira, antes de ser indicado para ser o primeiro ministro negro do Supremo Tribunal Federal, Joaquim Barbosa criticou a falta de efetiva observância da lei por parte do Ministério Público Federal. Ele atribuiu a ineficácia do Ministério Público à falta de organização, ao caos financeiro e também às lutas ideológicas internas. (GOMES, [200-]) Para Barbosa, a falta de envolvimento do Ministério Público tem sido encorajada pelos tribunais e o sistema judicial brasileiro e, em geral, reflete "o individualismo exacerbado, o extremo formalismo, a falta de racionalidade e o caráter prático na grande maioria das ferramentas disponíveis etc.” Ele completa que "diante do contexto, não é surpreendente que a situação geral das ações civis públicas é tão ruim que não existe nada para ser analisado no que diz respeito à proteção dos direitos das minorias por parte do Ministério Público!” (GOMES, 1999, p. 15-25) Desde que se tornou ministro do Supremo Tribunal Federal, Joaquim Barbosa tem apontado que "o mito da democracia racial impede que pessoas levem casos ao judiciário. As poucas pessoas que recorrem ao Ministério Público encontram agentes prontos para concluir que os cidadãos não estão apresentando um caso válido.”3

À luz da percebida ineficácia da legislação contra a discriminação no Brasil, muitas ONGs têm dedicado esforços para reformar a legislação de direitos civis. Uma conferência realizada em Brasília, em 2000, pelo advogado do Escritório Nacional Zumbi dos Palmares, Sérgio Martins, voltou as atenções para o desenvolvimento de mecanismos de combate ao racismo e à discriminação. Outras ONGs no Brasil, como o Centro de Articulação de Populações

3 Entrevista com Joaquim Barbosa, 14 de maio de 2007, p. 2 (transcrição em posse de Tanya K. Hernández). 
Marginalizadas (CEAP), têm funcionado como grupos que trabalham pela reforma da legislação antidiscriminação. ${ }^{4}$

Há indícios de que, à exceção dos ativistas que lutam pelos direitos civis, muitos profissionais do direito consideram a legislação antidiscriminação algo periférico. Poucos advogados consideram proveitoso ajuizar ações contra a discriminação racial, por temerem que tais ações sejam facilmente desconsideradas. A combinação da falta de conscientização geral sobre os direitos contra a discriminação com a relutância por parte dos profissionais do direito em aceitarem tais tipos de casos, e com a dificuldade de encontrar auxílio legal, provavelmente, faz com que milhares de casos de discriminação racial deixem de ser denunciados todos os anos. (JUSTICE STUDIES CENTER OF THE AMERICAS, 2004)

Contudo, há notícias de decisões judiciais em casos de discriminação contra a população afrodescendente, nos últimos anos, em várias áreas, incluindo na área penal, cível e em análises judiciais de programas de ação afirmativa. Além disso, pela primeira vez, estão sendo realizados estudos exploratórios do tratamento judicial de réus em casos criminais, assim como estudos da situação de mulheres negras no mesmo contexto. Como exemplo, o Instituto do Negro Padre Batista, no estado de São Paulo, foi criado através de um acordo com o procurador-geral do Estado, com o fim de ajuizar demandas penais. Pelo acordo, o procurador encaminhará para esse instituto todos os casos de racismo e injúria racial que ocorrerem no estado de São Paulo. Em 2004, o instituto só tinha, aproximadamente, 100 casos; um número baixo para o tamanho da população de afrodescendentes em São Paulo. Apenas algumas organizações representam afrodescendentes em demandas judiciais, uma delas o Instituto da Mulher Negra Geledés.

Fatores que contribuem para essa situação incluem a falta de uma consciência pública que permitisse que esses problemas pudessem ser resolvidos e a reduzida confiança na capacidade de o sistema judicial resolver tais casos adequadamente. Outro fator é que as delegacias policiais, aonde as vítimas devem se dirigir para registrar a ocorrência, frequentemente, não lidam com as referidas ocorrências de maneira séria ou dão informações inadequadas de como as vítimas devem proceder. As ações das delegacias de polícia mostram que a 
aplicação da legislação antirracismo encontra sérios problemas desde sua aprovação. Um estudo empírico demonstra deficiências graves nas respostas de organismos públicos às reclamações de racismo, que tendem a ser consideradas simples questões de honra, mesmo quando envolvem a proibição de acesso a transportes, direitos trabalhistas e proteção ao consumidor. (GUIMARÃES, 1998, p. 47) Um autor afirmou que "como resultado, advogados negros, com razão, reclamam sobre o real aumento de casos contra honra denunciados à polícia”. (GUIMARÃES, 1998, p. 47)

No estado do Rio de Janeiro há um órgão público chamado Disque Racismo, que lida com as demandas judiciais por racismo. Muitas das situações observadas em São Paulo são também comuns no Rio de Janeiro. Por exemplo, membros do Disque Racismo enfatizam a dificuldade em obter resultados favoráveis em demandas judiciais por racismo. Nos quatro anos após a inauguração do programa, em 1999, a organização obteve apenas três condenações. (JUSTICE STUDIES CENTER OF THE AMERICAS, 2004, p. 18) No contexto civilista latino-americano, como o do Brasil, cujos juízes decidem os casos, e não o júri, a baixa taxa de condenações reflete o ceticismo judicial no que diz respeito às demandas por discriminação.

Apesar disso, há uma tomada de consciência sobre as ferramentas legais antidiscriminação, como evidenciado pelo crescente número de ações ajuizadas. Só na Bahia, 220 pessoas ajuizaram ações por discriminação racial entre janeiro e outubro de 2008. O número contrasta nitidamente com o total de 308 casos levados ao Ministério Público da Bahia nos últimos 10 anos. (RACISMO..., 2008) No entanto, a grande maioria das demandas ajuizadas não obteve êxito. Um estudo das ações entre os anos de 2005 e 2006 revelou que apenas 32,9\% dos autores foram bem-sucedidos em suas demandas. (MENEZES, 2008) Similarmente, um estudo das ações julgadas nos anos de 2007 e 2008, novamente, revelou que apenas 30\% dos autores obtiveram êxito. (PAIXÃO et al., 2010, p. 264) Dificuldade similar é encontrada por autores de ações de discriminação no ambiente de trabalho nos Estados Unidos, onde 94\% das ações ajuizadas nunca vão a julgamento. Mais de $40 \%$ das ações de discriminação no ambiente de trabalho nos Estados Unidos são arquivadas antes do julgamento, e outros $54 \%$ dos autores frequentemente recebem apenas quantias simbólicas em acordos extrajudiciais. Os $6 \%$ restantes vão a julgamento, mas apenas uma em cada três ações tem chances de vitória. (NIELSEN; NELSON; LANCASTER, 2010, p. 175-201) 
Outro fator que impede a efetiva aplicação das leis antidiscriminação é a demanda por provas diretas de preconceito racial em vez de provas indiretas, como estatísticas que mostram os padrões das disparidades raciais. Um relatório do Centro de Estudos da Justiça das Américas sobre o sistema judicial brasileiro indica que a maioria das decisões judiciais no país exigem provas diretas da discriminação. (JUSTICE STUDIES CENTER OF THE AMERICAS, 2004) Esse é um critério de prova mais exigente, que torna mais difícil vencer o caso. Com efeito, conforme o critério da discriminação direta, o autor deve basicamente demonstrar a existência de três elementos diferentes: o ato discriminatório, o prejuízo causado pelo réu ao autor e a relação causal entre a discriminação racial e o ato discriminatório. Isso, portanto, requer que o acusado tenha intenção explícita de discriminar. Tal exigência é extremamente difícil de satisfazer em uma sociedade que se identifica como uma democracia racial e, por essa razão, não vê racismo nos usos corriqueiros das expressões que rebaixam o negro na sociedade.

A interpretação restritiva ou formalista do direito também impede a apresentação de ações de discriminação direta nos tribunais. Por vezes, os magistrados exigem que certo comportamento ou expressão, para ser qualificado como imputável, seja diretamente voltado contra uma pessoa de ascendência africana. Nesse sentido, por exemplo, um juízo determinou que chamar alguém de prostituta, vagabundo ou macaco não constitui racismo, uma vez que pessoas brancas também poderiam ser descritas dessa maneira. Assim, o judiciário ignora estereótipos culturais que associam negritude à prostituição, preguiça e qualidades de animais. Além do mais, a sentença veiculava o mito da "democracia racial" ao afirmar que, no Brasil:

as pessoas com pele mais escura podem até ser os ídolos de pessoas com pele mais clara nos esportes e na música, e as mulheres que são popularmente conhecidas como 'mulatas' parecem orgulhosas dessa condição e são exibidas com grande sucesso em muitos lugares famosos e populares. No Brasil, pessoas 'brancas' se casam regularmente com pessoas 'negras' e têm filhos [...]. Aqui não temos o racismo rigoroso e cruel observado em outros países, onde não-'brancos' são segregados, separados e não têm os mesmos direitos. Isso é racismo. (GUIMARÃES, 1998, p. 35)

Em alguns casos envolvendo ações ou expressões dirigidas a uma pessoa afrodescendente específica, o judiciário tem decidido que isso não representa 
um comportamento racista porque não prova que o preconceito ou intenção de discriminar foi dirigido contra a população afrodescendente como um todo. Por exemplo, no estado de São Paulo, a existência do crime de racismo não foi aceita pelo juízo em um caso em que o réu, um prefeito, disse a um funcionário da prefeitura por ocasião de sua demissão: "marginais e negros sujos não trabalharão mais aqui durante meu mandato”. A decisão afirma “dizer que uma pessoa particular é um ‘negro sujo’ ou que a administração municipal não os admitirá mais para o trabalho não constitui o crime (de racismo)”. O juízo completa que:

Discriminar, de acordo com o significado do próprio verbo, envolve proibir certas raças ou pessoas de certas religiões ou de certas cores de fazer uso de alguns direitos ou oportunidades que são conferidas a alguns segmentos da população. Isso não inclui exonerar alguém (em um lugar que muitos outros negros certamente continuam trabalhando) afirmando rudemente que a pessoa é um 'negro sujo', pelo menos para fins de configuração do crime previsto no artigo 20 da lei em questão [Lei 7.716/89, contra o racismo].

O juiz também concluiu que "como resultado, não há provas de uma oposição geral à raça negra na declaração do acusado, mas de um ataque verbal voltado exclusivamente à vítima e nada mais, porque, é importante notar, muitos negros continuam a servir a municipalidade (em questão)”. O tribunal concluiu que, no máximo, pode ter havido um crime de injúria; por essa razão o caso não pôde prosseguir e foi arquivado. ${ }^{5}$

O judiciário brasileiro tem feito pouco uso do critério de discriminação indireta, pelo qual o caráter discriminatório de um comportamento pode ser determinado pela presença de provas circunstanciais. Em tal caso, o autor deve provar que a vítima é parte de grupo específico (racial, nesse caso) e que ela recebeu tratamento diferente (inferior) do que o recebido por uma pessoa que não pertence ao grupo específico, independentemente da existência de manifestação explícita de intenção racista. O princípio da discriminação indireta parece ser aplicado apenas em casos de racismo ligados aos direitos dos consumidores. Esse critério tem sido usado para punir a discriminação praticada durante o acesso a clubes sociais ou no tratamento conferido a afrodescendentes em bancos. Em um exemplo, do primeiro caso, um magistrado decidiu que houve discriminação em uma casa 
noturna: o local tinha duas filas, uma supostamente para membros e outra para não membros; embora, na prática, os brancos da primeira fila podiam ingressar no local, enquanto os afrodescendentes da outra fila eram impedidos de comprar ingresso. O entendimento no caso foi o de que houve tratamento discriminatório contra membros de um grupo a despeito da falta de intenção discriminatória direta. ${ }^{6} \mathrm{Na}$ seara dos direitos do consumidor, um caso bem conhecido envolvendo um cliente negro que, ao tentar transferir uma pequena quantidade de dinheiro de sua conta bancária para a conta bancária da sua mulher, foi submetido a um longo e complexo interrogatório que excedeu em muito práticas bancárias corriqueiras para os clientes brancos. O órgão julgador também concluiu que tal comportamento foi racialmente motivado. (RACUSEN, 2002)

Como a tradição legal brasileira busca criminalizar o racismo e a discriminação racial (SILVEIRA, 2006), há uma tentativa de ampliação dos mecanismos para lidar com a discriminação. Em julho de 2010, o Brasil aprovou o Estatuto da Igualdade Racial. O Estatuto obriga o governo federal a administrar programas e adotar medidas específicas para reduzir a desigualdade racial. (BRASIL, 2010a) $\mathrm{O}$ artigo $1^{\circ}$ define que o estatuto é "destinado a garantir à população negra a efetivação da igualdade de oportunidades, a defesa dos direitos étnicos individuais, coletivos e difusos e o combate à discriminação e às demais formas de intolerância étnica”. É digno de nota que se trata da primeira legislação integral de promoção da igualdade racial na América Latina, com a articulação de metas governamentais para a promoção da inclusão racial e o desenvolvimento de políticas de ação afirmativa destinadas ao enfrentamento das desigualdades étnicas no tocante à educação, cultura, esporte e lazer, saúde, segurança, trabalho, moradia, meios de comunicação de massa, financiamentos públicos, acesso à terra, à justiça e outros. (BRASIL, 2010a, art. 4) O artigo 51 da lei cria Ouvidorias Permanentes para a Defesa da Igualdade Racial para receber e encaminhar reclamações de discriminação e monitorar a implementação de medidas de promoção da igualdade. Todavia, o estatuto tem sido criticado por ativistas afro-brasileiros por expressar simples aspirações e não proporcionar direitos concretos para garantir a igualdade nos moldes de políticas de ação afirmativa obrigatórias. (ALVES, 2010)

No resto da América Latina, as vítimas de discriminação racial podem recorrer apenas a princípios constitucionais genéricos de igualdade. Ainda que 
poucos advogados tenham tentado apresentar demandas de discriminação racial conforme a provisão genérica de igualdade constitucional, a medida judicial do amparo dá a possibilidade de se desenvolver uma estratégia judicial em favor da promoção da justiça social.

\section{O uso do amparo constitucional na América Latina}

Na América Latina, há uma poderosa fonte de efetivação constitucional: o recurso judicial do amparo (de nome alternativo, tutela). Amparo é uma ação constitucional que permite aos demandantes proteger seus direitos constitucionais e direitos humanos com uma variedade de medidas judiciais similares (incluindo liminares, sentenças declaratórias e mandados). Em todos os países latino-americanos, exceto a República Dominicana (e o Brasil), o amparo é previsto nas constituições nacionais. (BREWER-CARÍAS, 2009) Amparo é considerado um recurso extraordinário que deve ser usado apenas quando nenhuma outra medida judicial está disponível para a imediata proteção dos direitos humanos. Contudo, mais importante, trata-se de um direito pessoal de ação que qualquer indivíduo que tenha sofrido dano tem legitimidade para usar. Existe também uma tendência crescente de empregar o amparo para proteger direitos coletivos por meio da petição de alguém que tenha sofrido algum dano. Quatro países não autorizam o uso do amparo contra particulares, apenas contra autoridades públicas: El Salvador, Guatemala, México e Panamá. Em contraste, 10 países (Argentina, Bolívia, Chile, Costa Rica, República Dominicana, Nicarágua, Paraguai, Peru, Uruguai e Venezuela) autorizam ações de amparo contra particulares. Devido ao fato de que o amparo é fundamentalmente um direito pessoal de ação para proteger direitos constitucionais, a decisão de um tribunal somente vincula as partes da ação, e no que diz respeito à demanda apresentada. Não tem valor formal como precedente e, portanto, é limitada por sua incapacidade de produzir efeitos declaratórios gerais sobre alguma disposição legal atacada. Apesar disso, as decisões em sede de amparo podem informalmente gerar um efeito similar ao do precedente, pelo qual uma sucessão de decisões de amparo por parte dos mesmos juízes, rejeitando a aplicação da mesma lei com base em fatos bastante similares, aumenta a probabilidade de uma relativa uniformidade.

Um exemplo de um bem-sucedido uso do amparo para fazer avançar a igualdade racial ocorreu no caso de Liliana Cuellar Sinisterra, uma cidadã 
colombiana de ascendência africana, que estava em Cartagena para uma viagem de negócios representando o escritório de Houston da Deloitte and Touche. ${ }^{7}$ Em 2 de julho de 2005, Sinisterra teve acesso negado a uma casa noturna por causa da cor de sua pele. A vítima usou a tutela (equivalente colombiana à ação de amparo) para ajuizar uma ação contra a casa noturna que não permitira sua entrada, mas permitira a entrada de brancos. Com a tutela, ela ingressou com uma ação nos moldes do artigo 13 da Constituição colombiana, que protege a igualdade, a dignidade humana e a honra. Depois de perder no juízo municipal de Cartagena, Sinisterra apelou para a Corte Constitucional colombiana, e o tribunal reformou a decisão da tutela. A corte justificou a sua decisão com base no direito de não ser sujeito à discriminação racial ao tentar ingressar em lugares públicos e proibiu o estabelecimento de negar o acesso de pessoas por razões ilegais. Contudo, a despeito da existência do remédio judicial do amparo/tutela e do desenvolvimento de legislações domésticas antidiscriminatórias, há várias barreiras à efetiva aplicação de tais medidas na América Latina, como discutido na seção seguinte.

\section{O desafio de fazer cumprir as normas de dados raciais nos censos}

O legado e o apoio contínuo ao mito da democracia racial na América Latina têm interferido no reconhecimento de que recenseamentos com dados raciais podem auxiliar a promover a igualdade racial. Perguntas sobre identidade racial nos recenseamentos têm sido consideradas ato de discriminação. Ativistas que lutam pela justiça racial na América Latina questionam essa afirmação devido à urgente necessidade de demonstrar concretamente, com estatísticas, como atitudes sociais racializadas têm mantido os afrodescendentes em condição de subordinação.

Ainda que, nos diversos países, haja uma grande variação sobre aquilo que os juízes aceitam, em termos de dados provenientes das ciências sociais, como prova das desigualdades raciais em casos individuais de discriminação racial, a coleta sistemática de dados continua sendo útil. Isso porque denúncias individuais de discriminação podem ser apreciadas mais prontamente como discriminação quando os juízes estão expostos ao discurso público sobre a desigualdade racial generalizada, que contrasta com o mito da democracia racial. Além disso,

7 Tutela T-1250871; Corte Constitucional, sentencia T-131 del 23 de febrero de 2006, Liliana Cuéllar Sinisterra contra los establecimientos comerciales la Carbonera Ltda. y la discoteca Qka-Yito. 
a disponibilidade de dados raciais facilita a pressão por políticas governamentais de promoção da igualdade.

Por exemplo, devido ao fato de que o Brasil tem sido um dos poucos países da América Latina que incluiu de maneira regular uma questão de identificação racial nos censos decenais, suas organizações de justiça racial têm conseguido utilizar dados para apoiar suas reivindicações contra as inaceitáveis disparidades raciais no país. Em grande parte por essa razão, o Brasil é um dos poucos países da região a implementar políticas de ação afirmativa em concursos públicos e na área da educação.

Em contraste, como discutido no capítulo 2, a maioria dos países da América Hispânica e Caribe se recusaram firmemente a realizar recenseamentos com dados raciais. Todavia, esse quadro está lentamete começando a mudar. Ainda que a Venezuela tenha se recusado a coletar dados raciais nos seus censos desde 1873 (20 anos após a abolição da escravidão em 1854), em 2008 o governo anunciou que incluiria uma pergunta sobre raça no censo de 2010. Tal decisão foi resultado de um intenso lobby de organizações afro-venezuelanas com o suporte do Banco Interamericano de Desenvolvimento e do Banco Mundial. Através do financiamento, em 2000, de uma conferência internacional voltada para a necessidade de um recenseameno racial na região, o Banco Interamericano de Desenvolvimento e o Banco Mundial ajudaram muitos países latino-americanos a pressionarem politicamente seus governos. (POLITICAL..., 2000)

Além disso, o Banco Interamericano de Desenvolvimento tem ofertado um pequeno, mas crescente, número de empréstimos, para que os institutos nacionais de estatística realizem censos nacionais que melhorem a coleta de dados relacionados à raça e etnia. O Banco também tem ofertado auxílio técnico para financiar estudos específicos e pesquisas sobre raça e etnia. Agora os formulários dos censos da Colômbia, Cuba, Equador, El Salvador, Costa Rica, Porto Rico e Venezuela explicitamente contam afrodescendentes. Guatemala, Honduras e Nicarágua contam os afrodescendentes por meio da introdução de uma pergunta sobre ancestralidade étnica garifuna. Infelizmente, um acompanhamento feito em 2002 pelo Banco Interamericano de Desenvolvimento revelou que avanços têm sido notados na coleta de dados sobre indígenas, mas muito pouco na coleta de dados sobre afrodescendentes. (MAZZA, 2002, p. 3-5) Até que mais países na região se comprometam a solicitar dados raciais nos censos, afrodescendentes continuarão a lutar para tornar suas necessidades visíveis no discurso público e tangíveis nos tribunais. 
Enquanto alguns países aceitaram a demanda por dados raciais nos censos, outros governos recusaram tal demanda sob o argumento de que a fluidez das identidades raciais na América Latina compromete a possibiliade de coletar dados raciais. A afirmação do governo é equivalente a dizer: "como realmente podemos saber quem é negro?”. De fato, é verdade que aspectos demográficos e a ideologia racial na América Latina dissuadiram muitas pessoas de ancestralidade africana de se identificarem como negras. Todavia, o crescimento dos movimentos negros de justiça social na América Latina demonstra que a fluidez racial em termos de identidade pessoal não precisa conflitar com o entendimento político de hierarquia e disparidade racial. Certamente, a capacidade de um país multirracial, como o Brasil, de coletar dados raciais por décadas demonstra que outros países latino-americanos também podem fazê-lo.

Por exemplo, a despeito do fato de que o Equador reinseriu uma questão racial no censo apenas em 2011, quase 5\% da população se identificou como negro ou mulato. Além disso, quando o órgão recenseador realizou, em 2004, uma pesquisa sobre emprego com uma pergunta sobre racismo, a maioria dos afro-equatorianos afirmou saber o que era racismo, em contraste com a pequena porcentagem dos entrevistados indígenas que afirmaram o mesmo. (BECK; MIJESK; STARK, 2011) Essa pesquisa confirma um estudo de afro-equatorianos realizado em 2002, em Quito, o qual revelou que os entrevistados tinham consciência racial e percebiam o racismo e o preconceito nas suas comunidades e vida cotidiana. (DE LA TORRE, 2002) Similarmente, na Cuba atual, a despeito da retórica unificadora do patriotismo socialista e da democracia racial, categorias raciais são entendidas como elementos importantes para a compreensão da estratificação social. (SAWYER, 2006) Em outras palavras, o legado da democracia racial não precisa continuar obstruindo o reconhecimento da diferença e disparidade racial enquanto o sistema jurídico dispõe do suporte apropriado para lidar efetivamente com tais demandas.

\section{O desafio de fazer valer o Estado de Direito}

A reforma do sistema jurídico, com o objetivo de aumentar sua estabilidade, tem sido uma preocupação de longa data na América Latina. Em particular na década de 1980, quando se iniciou um intenso período de reforma judicial. (ÁLVAREZ, 1991) Projetos de reforma tentaram aumentar a qualificação dos servidores do judiciário, aumentar os orçamentos do judiciário e melhorar os 
padrões da carreira no judiciário. As prioridades da reforma judicial foram estabelecidas como uma resposta às avaliações dos países, os quais indicavam que juízes tinham acesso negado a recursos como treinamento, pessoal de apoio, materiais jurídicos básicos, códigos atualizados, instalações apropriadas e salários dignos. Além do mais, as avaliações mostraram que juízes sofriam, frequentemente, com influências políticas, conflitos de interesse e muita corrupção.

Desde aquele tempo, o judiciário na América Latina ainda é percebido por muitos usuários como uma instituição em crise (DAKOLIAS, 1996, p. 1) e os países da região consideram a reforma judicial uma prioridade. (BIEBESHEIMER, 2001, p. 99) Pesquisas de opinião, rotineiramente, demonstram que cidadãos têm pouca expectativa de receber tratamento justo nos sistemas judiciais latino-americanos, e de que essas instituições são as menos respeitadas nos setores público e privado. (HAMMERGREN, 1998, p. 4) A corrupção continua ocorrendo de maneira descontrolada porque o judiciário não tem autonomia financeira. Além do mais, enquanto o público geral percebe o processo de indicação ao judiciário como político, secreto e, portanto, isento de controle público, os cidadãos com menor renda têm particularmente um baixo nível de confiança no sistema judicial. Consequentemente, um número crescente de países latino-americanos instituíram a vitaliciedade e outras medidas de segurança para blindar os juízes da influência política. (SUTIL, 1999, p. 255-277)

Entretanto, recentemente acadêmicos começaram a questionar a imagem disseminada da América Latina como uma região "juridicamente falida”, uma vez que o discurso sobre a região, que transmite a imagem de formalismo desnecessário, ineficiência e corrupção, aplica-se a todos os sistemas jurídicos em graus diferentes. Jorge Esquirol, particularmente, identifica a promoção da imagem de uma América Latina juridicamente falida como um mecanismo para justificar mudanças nas políticas públicas, com inspiração neoliberal, sem maiores reflexões sobre os efeitos de tais mudanças nas populações marginalizadas. (ESQUIROL, 2008, p. 75-124) Por exemplo, com o discurso da "região juridicamente falida", muitas das históricas proteções que os códigos trabalhistas latino-americanos tinham concedido aos trabalhadores foram flexibilizadas. A alegação de "região juridicamente falida" favorece a privatização em larga escala e fragiliza o poder de os governos promoverem justiça social. Isso leva Esquirol a alertar as populações subordinadas sobre 
necessidade de não descartar o direito latino-americano como possibilidade de promoção da justiça social.

Apesar disso, para que as reformas de direito civil alcancem o máximo de eficácia, é preciso que seja levado em consideração o preconceito racial inconsciente dos juízes. (HAMMERGREN, 1998, p. 31) De fato, a existência de um violento sentimento contra a população negra e a população indígena no contexto social da América Latina e Caribe pode fazer que os juízes, inconscientemente, considerem os direitos civis meramente simbólicos, e não como um "direito para valer" que deve ser rigorosamente aplicado. (WHITE, 2003, p. 785873) Analistas apontam que a discriminação racial e o preconceito de classe ainda são fortes no sistema jurídico latino-americano. (BRYSK, 2000, p. 258) Para que os direitos civis sejam importantes na América Latina, educar o judiciário sobre a existência da discriminação e das limitações das normas de direitos civis se faz necessário. Além do mais, o contexto mais amplo de reforma judicial deve lidar com o fato de que, historicamente, "garantias constitucionais, frequentemente, têm oferecido, na prática, pouca ou nenhuma proteção para grupos vulneráveis", e que "elites poderosas tendem a operar 'acima' ou 'fora' do direito, a impunidade é generalizada e os poderosos fora da lei raramente são enquadrados nos rigores da lei”. (SIEDER, 2001, p. 142, 151) Considerando que apenas o texto das normas de direitos civis não é suficiente para mitigar a má influência do preconceito judicial, talvez a principal maneira de neutralizar tais efeitos seja interferir diretamente nos cursos de formação do judiciário. Isso poderia ser implementado por meio de escolas de formação do judiciário que têm surgido na América Latina com as primeiras iniciativas dos esforços modernos de reforma judicial.

Ademais, as aulas de formação do judiciário poderiam tratar também da importância de considerar dados das ciências para avaliar denúncias de discriminação (GASTWIRTH, 2000), já que os juízes não estão acostumados a ouvirem argumentos baseados em dados científicos. (COOK, 1999, p. 109115) Isso se deve, em parte, ao fato de que a formação jurídica latino-americana ocorre na graduação, em departamentos separados dos departamentos das ciências sociais das universidades. (PÉREZ-PERDOMO, 2006, p. 1049) Além do mais, como muitos professores de direito latino-americanos exercem outras carreiras jurídicas em tempo integral e ensinam em tempo parcial, em geral, não publicam pesquisas nem realizam estudos interdisciplinares. Essa situação é radicalmente oposta à realidade estadunidense, onde os estudos jurídicos fazem 
parte de um programa de pós-graduação antecedido por uma formação de quatro anos em nível de graduação, que pode ser na área de ciências sociais ou em outros cursos que o estudante prefira. Os cursos de direito nos Estados Unidos são oferecidos por professores de direito contratados não somente por suas habilidades de ensino, mas também por sua dedicação à pesquisa e à produção acadêmica, a qual pode ter natureza interdisciplinar.

Felizmente, a emergência de uma comunidade latino-americana de advogados dedicados ao interesse público começou a ampliar as possibilidades de qual tipo de prova é apropriada em juízo. (SUTIL, 1999, p. 255-277) As faculdades de direito na região aos poucos têm começado a incluir cursos voltados ao interesse público em seus currículos. Por exemplo, cursos sobre discriminação racial são oferecidos em escolas de direito na Argentina, Chile, Colômbia, Equador, Peru e Porto Rico. ${ }^{8}$ Há ofertas de cursos mais gerais sobre discriminação em várias escolas de direito na Argentina e no Equador. ${ }^{9}$ Escolas de direito mexicanas e venezuelanas oferecem cursos sobre direitos sociais e igualdade. ${ }^{10}$

8 Esses cursos incluem: Universidad Nacional de Córdoba (Argentina), Derechos Humanos UNIDAD III-Curso de Derechos Civiles y Políticos (en los que se incluye antidiscriminación), y Derechos Humanos UNIDAD VII - Curso de Fuentes de Derecho Internacional contra la Discriminación. Disponível em: <http://goo.gl/ti7eRp>; Universidad la República, Facultad de Derecho (Chile): curso Daños por discriminación. Disponível em: <http://goo.gl/Oqto6x>; Universidad del Cauca-Facultad de Derecho y Ciencias Políticas y Sociales (Colombia), curso Derecho de los Grupos Étnicos. Disponível em: <http://goo.gl/jtqnhG>; Facultad de Derecho de la Pontificia Universidad Católica del Perú, Curso sobre la igualdad en el empleo y la lucha contra la discriminación. Disponível em: <http://goo.gl/1sUC7W>; Facultad de Derecho Eugenio María de Hostos (Puerto Rico), curso de Discriminación en el empleo. Disponível em: <http://goo.gl/5MahKD>; y Facultad de Derecho de la Universidad Interamericana de Puerto Rico, curso de Discriminación en el Empleo. Disponível em: <http://goo.gl/L6K8Vx>.

9 Esses cursos incluem: Facultad de Derecho de la Universidad de Mendoza (Argentina), Derechos humanos y trabajo social (incluyendo la acción afirmativa). Disponível em: <http://goo.gl/IBMjRi>; Facultad de Derecho de la Universidad de Palermo (Argentina), curso Derechos Sociales (incluyendo la exclusión social y la desigualdad). Disponível em: <http://goo.gl/azM4qa>; Facultad de Derecho de la Universidad Nacional de Córdoba (Argentina), curso Desigualdad social y acceso a la justicia. Disponível em: <http://goo.gl/xwbYsM>; Facultad de Derecho de la Pontificia Universidad Católica del Ecuador, curso de Teoría y práctica de los derechos humanos (incluyendo la acción afirmativa y la exclusión social). Disponível em: <http://goo.gl/1TdXOH>.

10 Esses cursos incluem: Facultad de Derecho de la Universidad La Salle Pachua (México), curso Garantías individuales y derechos de los grupos vulnerables. Disponível em: <http://goo.gl/eOxK3d>; Facultad de Derecho de la Universidad Nacional Autónoma de México, curso Ética y derechos humanos (incluyendo derecho a la igualdad). Disponível em: <http://goo.gl/y9nB2r>; Universidad Panamericana-Facultad de Derecho (México), Seminario de Derechos Humanos: Igualdad y Antidis- 
Além do mais, praticamente todas as escolas de direito latino-americanas oferecem cursos em direitos humanos e suas fontes no direito internacional.

Uma dificuldade que continua limitando o acesso ao judiciário é a concentração de escritórios jurídicos em áreas urbanas. O Ministério Público e outros advogados públicos estão lotados principalmente em áreas urbanas. Esse sistema impede que boa parte da população rural negra tenha acesso aos serviços jurídicos. (GARRO, 1999, p. 278-301) México e Guatemala estão entre os poucos países que instituíram advogados públicos para comunidades rurais. (PLANT, 1999)

A alternativa de contratar um advogado particular é, de modo similar, dificultada pelo número limitado de advogados particulares em áreas rurais e também pela dificuldade de os possíveis autores conseguirem demonstrar a probabilidade de ganharem a ação, o que poderia lhes conferir a oportunidade de litigar sem os custos de administração judicial. Se não é possível vislumbrar chances de vitória no início do caso, os advogados particulares ficam menos inclinados a aceitar advogar em "novidades", como as ações por discriminação. Além do mais, somente aqueles autores que podem se beneficiar da assistência judiciária gratuita estão isentos do pagamento dos honorários advocatícios e das custas processuais. Essa prática contrasta com o sistema legal estadunidense, no qual as partes derrotadas não são automaticamente obrigadas a arcar com o ônus da sucumbência, exceto quando autorizado por lei. Por exemplo, o título VII da Lei dos Direitos Civis de 1964 autoriza que a parte autora vitoriosa solicite o reembolso dos honorários advocatícios em ações por discriminação no ambiente de trabalho. O réu, se vitorioso, só tem direito a receber honorários advocatícios se o autor "não for razoável, leviano, carente de mérito ou insultante”. (ESTADOS UNIDOS, 1978) Desse modo, apesar de existirem características estruturais projetadas para facilitar o acesso dos menos privilegiados ao judiciário na América Latina, os obstáculos para sua implementação limitam sua eficácia. Com todos esses obstáculos à aplicação da legislação antidiscriminação no âmbito nacional, os ativistas no campo da justiça social na região também se concentram na arena do direito internacional como uma

criminación (igualdad y no discriminación). Disponível em: <http://goo.gl/kKRzBR>; Facultad de Derecho de la Universidad Católica Andrés Bello (Venezuela), curso Condiciones sociales, económicas y políticas de acceso a la justicia. Disponível em: <http://goo.gl/V76k1W>. 
alternativa para o ajuizamento de ações e para o avanço de propostas de reforma no direito doméstico.

\section{O contexto internacional dos direitos humanos}

A maioria dos países latino-americanos é signatária da Convenção Internacional para a Eliminação de Todas as Formas de Discriminação Racial (Icerd). ${ }^{11}$ Essa situação contrasta com a posição dos Estados Unidos, que usou o direito de se reservar à aplicação da convenção. $\mathrm{O}$ artigo $6^{\circ}$ da convenção dispõe que "Os Estados-partes assegurarão, a qualquer pessoa que estiver sob sua jurisdição, proteção e recursos efetivos perante os tribunais nacionais e outros órgãos do Estado competentes, contra quaisquer atos de discriminação racial que, contrariamente à presente Convenção, violarem seus direitos individuais e suas liberdades fundamentais, assim como o direito de pedir a esses tribunais uma satisfação ou repartição justa e adequada por qualquer dano de que foi vítima em decorrência de tal discriminação". O órgão encarregado de fazer cumprir a convenção é o Comitê das Nações Unidas para a Eliminação da Discriminação Racial (Cerd).

Todos os países signatários da convenção são obrigados a submeter relatórios a cada dois anos ao Cerd, com o fim de detalhar como os direitos estão sendo implementados. A ONU avalia os relatórios e faz recomendações escritas ao Estado-parte. (UNITED NATIONS, 2006) A cada quatro anos o Conselho de Direitos Humanos das Nações Unidas também analisa os registros de direitos humanos de cada Estado-membro.

$\mathrm{O}$ artigo 14 da convenção estabelece um mecanismo de apresentação de denúncias de indivíduos e grupos que alegam ter sofrido danos por parte de um Estado-membro. Os denunciantes devem esgotar todos os mecanismos previstos no sistema doméstico. Uma vez recebida a denúncia, o comitê pode requisitar informações e fazer recomendações para o Estado-parte. O comitê da ONU se encontra duas vezes por ano em sua sede em Genebra, para analisar a documentação escrita das denúncias, e então faz recomendações aos Estados-membros.

11 Entre os países signatários latino-americanos estão: Bolívia, Brasil, Chile, Colômbia, Costa Rica, Cuba, República Dominicana, Equador, El Salvador, Guatemala, Honduras, México, Nicarágua, Panamá, Paraguai, Peru, Uruguai e Venezuela. Convención Internacional sobre la Eliminación de Todas las Formas de Discriminación Racial, 7 de marzo de 1966, en vigor desde el 4 de enero de 1969. Disponível em: <http://goo.gl/VtMq2q>. 
Ainda que os denunciantes não precisem viajar a Genebra para as audiências, as vítimas latino-americanas de discriminação racial geralmente não têm se servido da Icerd para fazer denúncias. Isso porque uma denúncia junto ao Icerd não pode ser considerada se a mesma situação estiver sendo investigada por meio de outro procedimento internacional. A via internacional escolhida tem sido a Comissão Interamericana de Direitos Humanos.

Assim como o comitê da ONU, a Comissão Interamericana de Direitos Humanos prepara relatórios sobre as condições dos direitos humanos no hemisfério ocidental. Além disso, recebe denúncias de indivíduos e organizações acerca de abusos de direitos humanos que violam a Convenção Americana de Direitos Humanos de 1969. A convenção assegura o direito à igualdade e à proteção judicial perante a violação de direitos fundamentais. Mas antes da realização de uma denúncia, o denunciante precisa esgotar todos os recursos legais disponíveis no país onde a violação ocorreu.

Os relatórios da comissão, com suas conclusões e recomendações, vinculam o Estado-membro investigado à medida que o obriga a responder ao relatório para esclarecer e indicar como pretende melhorar a situação. Então, a comissão decide quais denúncias devem ser apresentadas à Corte Interamericana de Direitos Humanos, na Costa Rica. A corte é autorizada a obrigar os Estados a reformarem suas leis ou adotarem outras medidas para lidar com as denúncias. Uma vez que a corte prolata a sentença, a Organização dos Estados Americanos (OEA) pode monitorar o efetivo cumprimento da decisão.

Infelizmente, nota-se que a OEA tem se autolimitado a receber os relatórios e deixado de fazer investigações autônomas para o acompanhamento do efetivo cumprimento das decisões. (GLOBAL RIGHTS PARTNERS FOR JUSTICE, 2004) Além do mais, a Corte Interamericana e a Comissão Interamericana não dispõem de meios de coerção direta pelos quais poderiam garantir a aplicação das suas decisões ou recomendações quando declaram que um Estado é responsável pela violação de direitos humanos, tampouco possui meios de obrigá-lo a tomar certas medidas de reparação à vítima. Entretanto, ignorar o pronunciamento legal que emana do sistema interamericano faz com que a reputação do país seja arranhada, gerando custos políticos. Em resumo, o valor do sistema interamericano reside na sua capacidade de conferir força política para aqueles que desejam modificar a situação.

Mais especificamente, o que tem sido considerado especialmente útil sobre o sistema interamericano é a atenção midiática e a consequente influência 
que as Organizações Não Governamentais conseguem angariar. Quando a Comissão Interamericana conduz uma visita ao local da denúncia para investigá-la ou preparar um relatório sobre o país, a comissão realiza encontros com agentes públicos, forças armadas, autoridades responsáveis por centros de detenção, polícia, igrejas e organizações da sociedade civil. Desse modo, a mera presença da comissão em um país gera debate público sobre os direitos humanos. As organizações da sociedade civil possuem mais condição de demandar dos governos quando a Comissão Interamericana e a Corte Interamericana obrigam um Estado a investigar a violação e punir os responsáveis; a efetuar reparações pecuniárias ou simbólicas; a implementar as apropriadas reformas legislativas, administrativas ou de outra natureza para erradicar a prática que foi considerada como violadora de direitos humanos. Em particular, a demanda interamericana por reforma legislativa é especialmente útil naquelas nações sem legislação interna efetiva para tratar da discriminação racial.

Para complementar o sistema interamericano, em 2004, a Comissão Interamericana criou uma relatoria sobre os Direitos de Afrodescendentes e contra a Discriminação. O objetivo central é ter um relator especial trabalhando juntamente aos Estados membros da OEA para aumentar a conscientização sobre o dever dos Estados de respeitar os direitos humanos de afrodescendentes e trabalhar para a eliminação de todas formas de discriminação racial, analisar os desafios atuais que os Estados da região enfrentam no que diz respeito ao racismo, formular recomendações voltadas à superação dos obstáculos, identificar e compartilhar as melhores práticas na região e monitorar e fornecer assistência técnica requerida pelos Estados-membros na implementação das recomendações na prática e no direito nacional. O trabalho do relator pode dotar as ONGs com dados específicos sobre a existência de discriminação racial em vez de tais dados serem agregados a um relatório geral sobre direitos humanos.

Consequentemente, o relatório abre caminhos para que as demandas por reformas raciais sejam mais influentes politicamente. Um exemplo útil é o relatório nacional realizado em 2009 sobre a situação da discriminação racial na Colômbia. (INTER-AMERICAN COMMISSION ON HUMAN RIGHTS, 2009) O informe do relator, inequivocamente, declara que as leis colombianas sancionadoras da discriminação racial são insuficientes para erradicar a vasta disparidade racial que existe no país. Portanto, o relator insta o governo a se engajar ativamente e a apoiar políticas voltadas a diminuir a exclusão social e as disparidades raciais. Em resumo, o enfoque especializado do relator facilita 
uma avaliação mais profunda de questões de discriminação racial. Com o advento do relator especial, as ONGs e as vítimas individuais de discriminação podem se colocar em melhor posição e utilizar as vias do direito internacional para lidar com questões de discriminação racial.

Apesar disso, o sistema interamericano tem sido difícil de ser acessado pelas vítimas de discriminação racial e seus mandatários por variadas razões. (GROSSMAN, 2008, p. 1267-1282) A exigência da Comissão Interamericana de que os requerentes esgotem as vias legais internas disponíveis no Estado onde a alegada violação ocorreu pode, inadvertidamente, dissuadir indivíduos de acionar o sistema. Pode parecer desalentador gastar verba para esgotar os recursos internos, que lidam inadequadamente com os danos causados pela discriminação racial, para só então despender ainda mais fundos para lançar mão do direito internacional.

Todavia, a Comissão Interamericana não exige o esgotamento dos recursos internos se a vítima teve acesso negado a tais recursos, se as leis locais não garantem o devido processo legal para a proteção dos direitos da vítima, quando o Estado causou atraso indevido, quando a pessoa não possui fundos para pagar por um advogado e o Estado não oferece o serviço gratuitamente ou quando os advogados do país em questão estão com medo de representar a vítima. Mas cada uma dessas exceções exige que a vítima arque com os custos para demonstrar a aplicabilidade da exceção e, assim, também representa um desincentivo para acionar o sistema. Além do mais, litigar na arena internacional é desafiador, por si só, porque o demandante tem o ônus da prova e, portanto, deve reunir provas significativas sobre o caso ou a situação. Dado que as reclamações podem ser enviadas via postal, e que os procedimentos se baseiam principalmente nos documentos escritos, os demandantes não precisam viajar para Washington, onde se encontra a sede da Comissão Interamericana, ou para a Costa Rica, onde se encontra a sede da Corte Interamericana. Apesar disso, devido à possibilidade de o processo no sistema interamericano durar vários anos, o denunciante deve estar preparado para enfrentar o processo por um longo período de tempo. Essa é uma limitação especialmente relevante, pois a corte interamericana tem a faculdade de solicitar a repetição de procedimentos já realizados na Comissão Interamericana se, segundo os critérios da corte, os procedimentos da comissão não atenderem aos seus padrões. ${ }^{12}$ A potencial necessi- 
dade de testemunhas viajarem para destinos internacionais distintos para prestar seus depoimentos aumenta o custo da litigância no sistema interamericano.

A despeito dos obstáculos no sistema interamericano de direitos humanos, ele continua sendo uma via alternativa promissora para lidar com casos de discriminação racial no hemisfério. É alentador que a Corte Interamericana tenha explicitamente declarado que uma concepção restritiva de direitos na seara doméstica não representa obstáculo para que o Estado tenha obrigações mais amplas na seara do direito internacional. ${ }^{13}$ De fato, o número de casos apresentados ao sistema interamericano tem aumentado bastante. Enquanto a Comissão Interamericana recebeu apenas 517 petições em 1998; em 2005, foram 1330 petições. ${ }^{14}$ Ainda mais significativas são as recentes decisões do sistema interamericano, indicando que está aberto para avaliar questões complexas envolvendo preconceito racial na região.

Por exemplo, em 2006, a comissão concluiu que o Estado brasileiro violara a obrigação de assegurar igualdade racial e o direito a um julgamento justo no caso de Simone André Diniz. (INTER-AMERICAN COURT OF HUMAN RIGHTS, 2004) No caso, Simone se candidatara a uma vaga de doméstica anunciada no jornal, a qual dizia que "brancos" tinham a preferência. Quando Simone, que é negra, ligou para obter informações sobre o emprego, perguntaram-lhe sobre a cor da sua pele e, quando ela se identificou como uma mulher negra, prontamente lhe foi dito que ela não atendia às exigências da vaga.

Contudo, quando Simone denunciou, para a polícia, a violação à lei brasileira contra discriminação racial, o Ministério Público, que é o responsável por denunciar tais crimes, se negou a oferecer a denúncia, sob a alegação de que não existia fundamento para afirmar que houve crime de racismo. Quando a recomendação do Ministério Público de arquivamento do caso chegou até o juiz, o mesmo ordenou o arquivamento da denúncia, a despeito das evidências de uma legítima acusação de racismo. A comissão, ao analisar as ações do Estado brasileiro, observou que o relatório Icerd 2004 apontou que o judiciário brasileiro tende a ser permissivo com a prática de discriminação racial, pois adota um padrão de arquivamento imediato de denúncias de discriminação racial, e que isso foi o que ocorreu no caso de Simone Diniz. Desse modo, a comissão concluiu

13 Case of the Mayagna (Suno) Awas Tingni Community v. Nicaragua, 2001 Inter-Am. Ct. H.R. (ser. C) $n^{\circ} 79$ (August 31, 2001).

14 Inter-Am. CHR, Annual Report, OEA/Ser.L/V/II.124, doc. 5, cap. 3, p. 8, 2006. 
que o Estado brasileiro violara a cláusula de igualdade prevista no artigo 24 da Convenção Americana de Direitos Humanos. As recomendações feitas pela comissão incluem indenizar Simone Diniz satisfatoriamente pela violação de direitos humanos, garantir assistência financeira para que ela possa melhorar sua formação, reformar a lei antirracismo para torná-la mais efetiva, conduzir uma investigação sobre os fatos alegados por Simone na denúncia arquivada e oferecer formação aos agentes policiais em como se comportar de maneira adequada para a aplicação da lei antirracismo.

Ainda que as recomendações da comissão não sejam obrigações jurídicas do Estado, a atenção pública que o relatório da comissão propicia teve uma influência no caso Diniz. À época do relatório anual da comissão, em 2010, foi apontado que o Estado brasileiro tinha parcialmente realizado as recomendações, uma vez que Simone Diniz tinha sido indenizada pelas violações aos direitos humanos e a responsabilidade do Estado pela violação havia sido publicamente reconhecida. Sem dúvida, o sistema interamericano é um processo demorado e de resultados ambíguos, mas o caso Diniz mostra que é possível pressionar para conseguir promover a causa da igualdade racial na América Latina.

Menos bem-sucedido, entretanto, foi um caso posterior, de Wallace de Almeida, um jovem soldado do Exército brasileiro que foi assassinado pela Polícia Militar do Rio de Janeiro no caminho de casa, no Morro da Babilônia. (INTER-AMERICAN COURT OF HUMAN RIGHTS, 2006) A comissão concluiu que o Estado brasileiro violou a obrigação de tratar todas as pessoas igualmente e sem discriminação perante a lei, trazida pelo artigo $24 \mathrm{da}$ Convenção Americana de Direitos Humanos. Vale ressaltar que a comissão destacou o fato de a polícia brasileira levar em conta o perfil racial das pessoas para, sistematicamente, lançar mão de táticas policiais violentas, com a presunção de que todos os moradores negros das favelas são necessariamente criminosos, caracterizando o fato como uma violação aos direitos humanos que o Estado brasileiro foi obrigado a investigar sem preconceito. Isso porque uma obrigação estatal, por força da convenção, estende-se não somente às ações diretas, mas também às demais autoridades públicas, tais como policiais, promotores e juízes. Consequentemente, a comissão recomendou que os parentes de Wallace de Almeida fossem indenizados pelo homicídio, que uma investigação completa e imparcial do assassinato se iniciasse com o objetivo de processar os criminosos, e que o Estado adotasse medidas para educar juízes e policiais para evitar discriminação racial nas operações da polícia, 
investigações, processos e condenações criminais. A disposição da comissão em identificar a discriminação racial como um fator causal da morte de Wallace de Almeida foi uma vitória significativa dos denunciantes. Infelizmente, mais de 10 anos depois do assassinato de Wallace, o Estado brasileiro ainda não cumpriu nenhuma das recomendações e a comissão continua monitorando o caso.

Em resumo, enquanto latino-americanos afrodescendentes encontram alguma utilidade ao recorrer aos marcos do direito internacional, as dificuldades para cumprimento das recomendações, prazos longos e o limitado acesso às ferramentas do direito internacional reforçam a necessidade de reforma dos sistemas jurídicos domésticos, para que se promova a igualdade racial. De fato, a Assembleia Geral da Organização dos Estados Americanos tem apontado que há dificuldades em lidar com a discriminação racial com base na categoria mais ampla de direitos humanos. Como resultado, a OEA, em 2000, iniciou um projeto para o desenvolvimento de uma Convenção Interamericana contra o Racismo e todas as Formas de Discriminação e Intolerância. (ORGANIZATION OF AMERICAN STATES INTERNATIONAL LAW DEPARTMENT, 2009) Desde então, um projeto de convenção tem sido elaborado e sessões especiais estão sendo conduzidas com o propósito de promover a adoção pelos Estados membros da OEA. Se amplamente adotada, a convenção poderia apoiar pesquisas para promover a consciência da discriminação racial na região, além de monitorar padrões de disparidade racial nos Estados. Através da identificação de pessoas de ascendência africana nas Américas como sujeitos de direitos, a convenção ajudaria a importante luta de fazer com que os Estados compreendam e lidem com as desigualdades raciais.

Contudo, existe resistência para a adoção da Convenção Interamericana contra o Racismo e Todas as Formas de Discriminação e Intolerância. (KAMIENSKA-HODGE, K.; LAJZER, J., 2009) Alguns Estados-membros têm se oposto à criação de uma convenção exclusiva sobre racismo e, em contrapartida, propõem que a convenção seja mais ampla e abranja outras formas de preconceito e marginalização, como a idade, origem nacional e muitas outras. A visão de que a discriminação racial não é a perspectiva mais importante na abordagem de problemas sociais na América Latina justifica a resistência à convenção sobre racismo e acaba fazendo com que a mesma não avance. Essa perspectiva destoa bastante do marco legal internacional das últimas décadas, o qual tem optado pelo uso de convenções dedicadas a temas únicos. Por exemplo, há uma convenção focada em gênero, Convenção Interamericana para a Prevenção, 
Punição e Erradicação da Violência contra as Mulheres, e há uma convenção voltada às pessoas com deficiência, Convenção Interamericana para a Eliminação de Todas as Formas de Discriminação Racial contra Pessoas com Deficiência. Também houve uma enorme mudança em relação ao modo como foi concebida, em 2000, a Convenção Interamericana contra o Racismo e Todas as Formas de Discriminação e Intolerância, como um mecanismo para tornar o foco antirracista da Convenção Internacional para a Eliminação de Todas as Formas de Discriminação Racial (Icerd) mais relevante para as necessidades das Américas, uma vez que o foco inicial da Icerd, 40 anos atrás, foi voltado para questões de apartheid e colonialismo. Ao longo do tempo, o aporte dos vários Estados-nações buscou diluir a atenção dada predominantemente ao racismo, de modo a refletir a concepção da América Latina como racialmente inocente. Baseado na noção de que os Estados latino-americanos são inocentes de terem cometido atos racistas, por não ter havido uma segregação estatal no estilo Jim Crow na região, delegações de Estados-nações latino-americanos consideram o racismo uma aberração, em vez de considerá-lo uma parte sistêmica de cada cultura nacional. A explicação dada neste livro sobre o papel do direito costumeiro de regulação racial na América Latina contradiz radicalmente essa perspectiva e talvez pudesse ser de utilidade nos esforços para vencer a resistência a uma convenção exclusiva para tratar do racismo no sistema interamericano. Invocar o histórico do direito costumeiro de regulação racial pode conferir aos atores de movimentos de justiça social o poder retórico necessário para desacreditar a noção da inocência racial do Estado, que impede a consideração de medidas efetivas e corretamente orientadas para lidar com o racismo em uma convenção específica sobre raça.

A América Latina aos poucos vem tirando a máscara da suposta democracia racial e está começando a estabelecer mecanismos para reconhecer os prejuízos da discriminação racial. Mas para uma população que, por tanto tempo, tem se considerado livre da crueldade da discriminação ao estilo da estadunidense, os latino-americanos afrodescendentes ainda são desproporcionalmente pobres, mais atingidos pelo desempregado e menos beneficiados pela educação formal se comparados ao restante da população. $\mathrm{O}$ desenvolvimento de estruturas antidiscriminação na América Latina certamente será uma ferramenta útil para auxiliar os afrodescendentes a lutar por igualdade racial. Contudo, ainda há muito a ser feito. Movimentos de afrodescendentes estão conscientes de que proteções jurídicas mais amplas ainda são necessárias contra a discriminação 
racial. Como resultado, além de fazer lobby pela aplicação mais efetiva de direitos civis, os movimentos de justiça social também lutam pela implementação de políticas obrigatórias de ação afirmativa, conforme a discussão feita no próximo capítulo. 


\section{Brasil: na vanguarda latino- americana das políticas de ação afirmativa baseadas em raça e dos recenseamentos com recorte racial}

A inexistência de dados sobre raça em muitos países latino-americanos dificulta não só a capacidade de reunir sistematicamente estatísticas sobre um grupo social que demonstre a sua exclusão racial, mas também a capacidade de pressionar efetivamente por políticas de ação afirmativa baseadas em raça para melhorar a situação de exclusão racial. Até agora, a criação de programas e políticas de ação afirmativa na América Ibérica tem sido bastante modesta.

A Colômbia é o único país que destina assentos no Poder Legislativo a afrocolombianos, na Câmara dos Deputados (em vez de apenas para mulheres, como em muitos países latino-americanos, como Argentina, Bolívia, Colômbia, Costa Rica, República Dominicana, Equador, México, Panamá, Paraguai e Peru). (HTUN, 2003) Mais especificamente, a Constituição colombiana reconhece a representação política de afrodescendentes e populações indígenas na Câmara dos Deputados e no Senado. ${ }^{1}$ Além disso, em 1996, a Colômbia criou um programa de créditos educativos para comunidades afro-colombianas. (COLÔMBIA, [20--]) Esse programa consiste na alocação de créditos 
universitários para afro-colombianos em troca de prestação de serviços: "serviço comunitário, social, acadêmico, conforme o projeto apresentado por ocasião da candidatura, que é garantida por uma organização de base”. Os requisitos para ser beneficiado pelo programa são possuir um certificado de participação em uma comunidade afro-colombiana, excelência acadêmica, hipossuficiência econômica e apresentação de um projeto para resolver problemas ou necessidades da comunidade de origem. (LEÓN; HOLGUíN, 2004)

Além do mais, várias universidades colombianas, tanto públicas como privadas, criaram programas especiais de admissão para minorias étnicas, incluindo afro-colombianos. (LEÓN; HOLGUíN, 2005, p. 208-211; LEÓN; HOLGUÍN, 2004, p. 60) As vagas reservadas variam de duas a cinco por curso. (PASCALE, 2010, p. 42) Os programas de ação afirmativa, primeiro, começaram admitindo estudantes indígenas, em seguida foram ampliados para incluir colombianos afrodescendentes. (HEREDIA et al., 2009)

De modo similar, no Equador, o governo tem feito planos para estabelecer uma cota de $10 \%$ para estudantes afro-equatorianos e indígenas em instituições de ensino médio públicas e privadas. Isso porque o artigo 11.2 da Constituição equatoriana declara que "O Estado adotará ações afirmativas para promover igualdade em favor daqueles que se encontram em situação de desigualdade”. (EQUADOR, 2008) O governo também planeja estabelecer cotas para professores e pesquisadores em universidades. (PLAN PLURINACIONAL, 2009, p. 35) De modo mais limitado, o governo, juntamente com a Universidade Andina Simón Bolivar, criou um programa no qual 15 advogados afro-equatorianos receberam bolsas para uma especialização em direitos humanos, que terá ênfase em comunidades afrodescendentes. (15 ABOGADOS..., 2011) Outro programa governamental ofereceu 10 bolsas para estudantes afro-equatorianos que querem fazer cursos de mestrado. (BECAS, 2011) No campo dos empregos públicos, o governo equatoriano também planeja uma política de ação afirmativa para contratação em vários órgãos governamentais. ${ }^{2}$

O governo equatoriano também fez acordos com seis governos locais diferentes para construir casas especialmente para afro-equatorianos. Por exemplo, em um acordo com a entidade subnacional de Canton Ibárra, o governo se comprometeu em investir 700 mil dólares para a implementação de um programa 
que criaria 250 unidades habitacionais para afrodescendentes da região, e o Canton Ibárra seria responsável pela implementação do programa. Ainda que 700 mil dólares possam parecer um valor modesto, deve-se observar que o custo médio da construção de uma unidade habitacional de $100 \mathrm{~m}^{2}$ no Equador é de 36 mil dólares.

Em Honduras, o governo criou um programa de bolsas para estudantes afro-hondurenhos que querem continuar o ensino médio e ingressar na universidade. ${ }^{3}$ No Uruguai, o Ministério da Educação e Cultura dispõe de um fundo que oferece bolsas para estudantes afro-uruguaios. Há também bolsas de pós-graduação, como a bolsa Carlos Quijano, voltada para estudantes afro-uruguaios. (PASCALE, 2010, p. 44)

Em resumo, a disponibilidade de programas de ação afirmativa na América Latina é bastante limitada se comparada com a dos Estados Unidos, onde um número incontável de empregadores, universidades e órgãos públicos têm políticas de ação afirmativa. Os primeiros passos para considerar a ação afirmativa de maneira mais ampla na América Latina têm se dado na forma de organismos governamentais criados para auxiliar a promoção da igualdade. Ouvidores públicos especialmente voltados para questões de racismo podem ser encontrados em todos os países latino-americanos, exceto em El Salvador, Chile e Paraguai. Por exemplo, na Venezuela, a Comissão Presidencial para a Prevenção e Eliminação de Todas as Formas de Discriminação Racial e Outras Distinções no Sistema Educacional Venezuelano é responsável por promulgar políticas antidiscriminatórias. Contudo, até agora, a única norma aprovada foi um decreto declarando 10 de maio o dia do afro-venezuelano. (VENEZUELA, 2005)

Ainda que tal tipo de legislação simbólica certamente seja importante para chamar a atenção para a existência e a difícil situação dos afrodescendentes, há uma carência na América Latina de programas que lidem diretamente com a questão das instituições que barram afrodescendentes devido a preconceitos e estereótipos raciais. Portanto, a Venezuela é um exemplo emblemático da adoção incipiente de ações afirmativas na América Latina. Em contraste, o Brasil se destaca como a nação latino-americana com o maior número de políticas de ações afirmativas voltadas para afrodescendentes.

3 Decreto ejecutivo 09, 2007 (Honduras). 


\section{O debate sobre ação afirmativa no Brasil}

Há várias razões para o Brasil ser o país latino-americano que mais adota ações afirmativas baseadas em raça. Os movimentos afro-brasileiros de justiça social foram ativos participantes da Conferência Mundial das Nações Unidas contra o Racismo em 2001. A atenção pública que a conferência ofereceu para os assuntos de igualdade racial permitiu que ONGs exercessem pressão sobre o governo brasileiro. Além disso, a ênfase da conferência no apoio às ações afirmativas, feito pelo texto da Convenção Internacional para a Eliminação de Todas as Formas de Discriminação Racial, proporcionou fundamentos jurídicos para uma ação do Poder Executivo. O artigo $1^{\circ}$, seção 4, da convenção, da qual o Brasil é um dos signatários, estabelece que

Não serão consideradas discriminação racial as medidas especiais tomadas com o único objetivo de assegurar o progresso adequado de certos grupos raciais ou étnicos ou de indivíduos que necessitem da proteção que possa ser necessária para proporcionar a tais grupos ou indivíduos igual gozo ou exercício de direitos humanos e liberdades fundamentais, contanto que tais medidas não conduzam, em consequência, à manutenção de direitos separados para diferentes grupos raciais e não prossigam após terem sido alcançados os seus objetivos.

O então presidente Fernando Henrique Cardoso foi especialmente receptivo à questão das ações afirmativas devido ao seu próprio trabalho intelectual como um proeminente sociólogo que lidou com a questão da desigualdade racial no Brasil. (HTUN, 2004, p. 60-89) Por exemplo, como sociólogo, o presidente Fernando Henrique Cardoso escreveu, juntamente com Octavio Ianni, o livro Cor e mobilidade social em Florianópolis: aspectos das relações entre negros e brancos numa comunidade do Brasil Meridional. (CARDOSO; IANNI, 1960)

Em consequência, o Brasil começou a instituir políticas de ação afirmativa em 2001, quando o Ministério da Agricultura determinou que 20\% dos seus servidores fossem negros, que $20 \%$ dos empregados das empresas contratadas pelo ministério fossem negros e que outros $20 \%$ fossem mulheres. (RACUSEN, 2004, p. 811-812) Depois disso, o Supremo Tribunal Federal (STF) e outros órgãos públicos também instituíram políticas de ação afirmativa. (RACUSEN, 2004, p. 812-813) O programa de ações afirmativas do STF estabeleceu uma cota de $20 \%$ de afrodescendentes para as empresas contratantes com o órgão. (CESAR, 2003, p. 28) O programa de ação afirmativa do Ministério 
da Justiça estabeleceu que $20 \%$ das posições de direção superior deveriam ser preenchidas por afrodescendentes. A administração pública federal estabeleceu o Programa Nacional de Ação Afirmativa, que previa uma série de metas percentuais para a participação de afrodescendentes na administração pública, além de obrigações similares para as empresas contratantes com o poder público federal. Por sua vez, um programa do Instituto Rio Branco passou, em 2001, a oferecer bolsas voltadas à preparação de afrodescendentes aos estudos para o concurso de admissão à carreira diplomática. Além disso, em 2002, a Lei n. ${ }^{\circ} 10.558$ criou o Programa Diversidade na Universidade, no âmbito do Ministério da Educação, com a finalidade de implementar e avaliar estratégias para a promoção do acesso ao ensino superior de pessoas pertencentes a grupos socialmente desfavorecidos, especialmente dos afrodescendentes e dos indígenas brasileiros. O programa incluía financiamento para entidades públicas e privadas, sem fins lucrativos, que atuassem na área de educação e que viessem a desenvolver projetos inovadores para atender a finalidade do programa.

Assim como o governo federal brasileiro, os governos locais começaram a instituir programas de ação afirmativa. Por exemplo, em junho de 2011, o estado do Rio de Janeiro aprovou um decreto instituindo a reserva de $20 \%$ das vagas para negros e pessoas de ascendência indígena nos concursos públicos do estado. (RIO DE JANEIRO, 2011) Importante salientar que enquanto grande parte do discurso público no Brasil confunde o conceito de ação afirmativa com a adoção de cotas, na realidade, os programas de ação afirmativa existentes variam em seu conteúdo e estrutura. (HERINGER, 2004, p. 55-86) Em outras palavras, nem todos os programas de ação afirmativa no Brasil se materializam em forma de cotas.

Ainda mais controversa tem sido a implementação direta de programas de ação afirmativa baseados em raça no ensino superior, aos quais a maioria dos ministros de educação tem se oposto. (DZIDZIENYO, 2005, p. 137-155, 147) Em 2000, a Universidade do Estado do Rio de Janeiro (UERJ) instituiu cotas diretas de $40 \%$ para os estudantes negros e $10 \%$ para estudantes com deficiência. (RIO DE JANEIRO, 2000, 2001) A política de ação afirmativa foi contestada primeiro perante o STF, por uma associação de instituições particulares de ensino (Confenen), como uma violação à provisão constitucional de proporcionalidade no exercício da discrição legislativa (razoabilidade). (RACUSEN, 2004, p. 816) Essa ação judicial ficou prejudicada quando a Assembleia Legislativa do Rio de Janeiro revisou a política, em 2003, para estabelecer um número mais 
limitado de cotas, $20 \%$, para pessoas autodeclaradas negras, $20 \%$ para estudantes de escolas públicas e 5\% para pessoas portadoras de deficiência e indígenas. (RIO DE JANEIRO, 2003) Além disso, todos os estudantes admitidos via a política de cotas deveriam ter um perfil econômico específico. (RACUSEN, 2004, p. 816-817) Após as alterações, a política de ação afirmativa foi novamente contestada judicialmente juntamente com as políticas de ação afirmativa da Universidade de Brasília (UnB), da Universidade Federal do Rio Grande do Sul e da Universidade Estadual do Norte Fluminense. Apenas no caso das duas universidades fluminenses, mais de 300 candidatos descontentes ajuizaram ações contra as políticas de ação afirmativa. (RACUSEN, 2004, p. 815)

Além do mais, 114 acadêmicos assinaram um manifesto, em 2006, se opondo à ação afirmativa baseada em raça, considerando-a inconstitucional e um meio de promover conflito e intolerância. (OSAVA, 2006) Poucos dias depois, 330 intelectuais e representantes de movimentos sociais assinaram uma resposta intitulada "Manifesto em Favor das Leis de Cotas e do Estatuto da Igualdade". Os documentos foram amplamente discutidos na mídia brasileira e o debate continuou, como indica uma pesquisa nacional datada de 2008, sugerindo que $62 \%$ dos brasileiros acreditam que as políticas são essenciais, enquanto outros $53 \%$ acreditam que os programas são humilhantes e $62 \%$ pensam que as políticas podem causar racismo. (GOIS, 2008) Considerando que uma pessoa poderia responder a mais de uma questão, o resultado sugere que muitos brasileiros apresentam um conflito interno sobre o uso de ações afirmativas baseadas em raça. O discurso contrário à ação afirmativa tem sido tão virulento que mesmo alguns dos primeiros beneficiários das políticas demonstram ambivalência na defesa da política. (GONZÁLEZ, 2010, p. 123-138) Como resultado, o STF realizou uma audiência pública em março de 2010 para reunir informação de pessoas com experiência e conhecimento técnico na área de ações afirmativas.

A ação perante o STF argumentou que o sistema de cotas violava o princípio constitucional da igualdade perante a lei prevista no artigo $5^{\circ}$ da Constituição brasileira de 1988, segundo o qual "Todos são iguais perante a lei, sem distinção de qualquer natureza, garantindo-se aos brasileiros e aos estrangeiros residentes no país a inviolabilidade do direito à vida, à liberdade, à igualdade, à segurança e à propriedade”. O argumento foi o de que os estudantes brancos tiveram sua admissão negada, mas marcaram mais pontos nas provas de admissão que candidatos que foram aceitos pelo sistema de cotas, portanto os estudantes brancos teriam sido tratados de maneira desigual. (BRASIL, 2010b) Também é 
importante notar que todas as alegações dos autores afirmavam inexistir práticas racistas institucionalizadas e chanceladas pelo Estado no Brasil (como a segregação da legislação Jim Crow nos Estados Unidos) tornando desnecessária a adoção de ações afirmativas no Brasil, sendo a implementação de ações afirmativas uma imposição racista. Por exemplo, na ação movida contra o programa de ações afirmativas da Universidade de Brasília, o autor questionava "se a implementação de um Estado racializado ou um racismo institucionalizado, como o praticado nos Estados Unidos, África do Sul ou em Ruanda, seria adequado para o Brasil.” (BRASIL, 2009) As alegações, como um todo, reforçavam que o argumento do ideal de democracia racial deve ser preservado em um país tão miscigenado racialmente, cujas designações raciais são tão difíceis de administrar. (SILVA, 2009) Nessa narrativa, o papel histórico do Estado como facilitador da exclusão racial e o papel do direito costumeiro de regulação racial estão completamente ausentes.

Parte da peça do recurso apresentado ao STF lançava mão do voto de um desembargador do Tribunal de Justiça do Rio de Janeiro, de maio de 2009, o qual declarava a lei de ação afirmativa do Rio de Janeiro inconstitucional, com a justificativa firmemente calcada na ultrapassada noção de ser o Brasil uma democracia racial. Especificamente, o voto declarava que o sistema de cotas criava privilégios para uma parte da população brasileira, constituída de pessoas irreversivelmente mestiças, e privilégio no mais alto ponto do processo educacional do país, que são as universidades. Abre-se a possibilidade de que, em um país onde a mistura racial é a regra, surja, por força de lei, um apartheid que não existe no Brasil. (RIO DE JANEIRO, 2009a)

Para esse juiz, assim como para boa parte da elite branca, a rejeição frontal às ações afirmativas está firmemente enraizada na premissa de que a exclusão racial não é parte da cultura brasileira, e que a ação afirmativa criará a segregação que atualmente existe em países, como os Estados Unidos, onde são usadas ações afirmativas.

Porém, não estava claro se tais perspectivas seriam acolhidas. Quando a política de ação afirmativa da Universidade do Estado do Rio de Janeiro foi analisada em segunda instância, o resultado no tribunal foi de 15 votos contra e seis a favor da constitucionalidade da política. (RIO DE JANEIRO, 2009b) Em 19 de março de 2012, o STF arquivou o recurso porque a norma atacada havia sido revogada por uma nova lei de ação afirmativa em 2008, a qual limitou a duração do programa em 10 anos. (BRASIL, 2012a) 
Ainda mais importante, em 26 de abril de 2012, o STF proferiu a decisão que declarava constitucional a política de ação afirmativa da Universidade de Brasília. (BRASIL, 2012b) Em uma decisão unânime, a corte afirmou que, para o país efetivar o princípio da igualdade, as políticas de ação afirmativa são uma importante obrigação e responsabilidade social do Estado, porque a Constituição requer a reparação das perdas impostas aos afro-brasileiros no passado. Além do mais, apenas uma semana depois, a corte também confirmou a constitucionalidade do Programa Universidade para Todos (ProUni), que oferece bolsas para estudantes afrodescendentes de famílias de baixa renda para cursarem universidades privadas. (BRASIL, 2012c) Com essas duas decisões, o STF afirmou a prioridade constitucional de reduzir as desigualdades sociais e o uso de ações afirmativas como uma importante ferramenta de integração social.

Ademais, com o passar do tempo, um número crescente de brasileiros e beneficiários do programa começaram a ver as ações afirmativas como algo positivo. De fato, em uma pesquisa de 2010, 85,4\% dos candidatos negros e indígenas declararam que estavam de acordo com o sistema de cotas. (VESTIBULAR UERJ, 2010) Em contraste, cinco anos antes, apenas 66,8\% dos candidatos a cotistas declararam que a política de ação afirmativa era positiva. (TREVIÑO GONZÁLEZ, 2010, p. 127)

Especialmente reveladora é uma pesquisa de 2010 sobre as atitudes em relação às ações afirmativas, que identificou o percentual da população brasileira que se opõe às ações afirmativas. Na pesquisa de 2010 realizada pelo Americas Barometer, descobriu-se que um alto percentual de brasileiros acredita que reservar lugares nas universidades para afrodescendentes é justo. De fato, dentre os $66,2 \%$ dos que concordam, $45 \%$ "concordam bastante". Dentre os $27,4 \%$ que desaprovam, apenas 18\% "desaprovam bastante". Os 6,5\% restantes não aprovam nem desaprovam. Entretanto, a minoria que "desaprova bastante” é majoritariamente branca, tem ensino superior e é bastante ativa na mídia e no discurso público. (SMITH, 2010) Assim, enquanto a mídia brasileira tem oferecido bastante espaço para as vozes brancas contrárias (e universitárias) criticarem as ações afirmativas, na verdade elas representam uma pequena minoria da população. De fato, mais de dois terços dos brasileiros, conforme o Americas Barometer de 2010, que apoiam as ações afirmativas baseadas em raça, pertencem a todas as raças e afiliações políticas.

Isso explica o porquê de as políticas de ação afirmativa nas universidades continuarem a proliferar de várias formas, a despeito da recusa do Congresso 
Nacional em incluir políticas de ação afirmativa no Estatuto da Igualdade Racial. (BRASIL, 2003) Em agosto de 2010, pelo menos, 80 universidades públicas já haviam adotado políticas de ação afirmativa. As estruturas dos programas variam. (RACUSEN, 2009; CORREA, 2008, p. 6-39) Alguns programas são voltados apenas para estudantes afro-brasileiros oriundos de escolas públicas de ensino médio, como uma maneira de atingir os estudantes afro-brasileiros mais necessitados. Outros programas reservam vagas para estudantes oriundos de escolas públicas de ensino médio de qualquer raça, assim estabelecendo reservas conforme a densidade demográfica proporcional de cada grupo na região. Outra variação reserva vagas para estudantes afro-brasileiros oriundos de escolas de ensino médio públicas ou privadas e há outra variação que reserva vagas para estudantes de escolas públicas de qualquer raça. Finalmente, algumas universidades atribuem pontos extras ao resultado dos exames de admissão de candidatos afro-brasileiros e também para estudantes oriundos de escolas públicas de ensino médio.

Ao considerar o contexto de programas de ação afirmativa em universidades públicas, é importante notar que, ao contrário dos Estados Unidos, onde muitas Instituições de Ensino Superior (IES) privadas são consideradas mais prestigiosas que, com algumas exceções, qualquer universidade pública, as instituições públicas de ensino superior brasileiras estão em alta conta na consideração dos brasileiros, em oposição à maioria das universidades privadas. (TELLES, 2004, p. 124-159) Tanto as universidades públicas gratuitas como as universidades particulares pagas realizam seu próprio processo seletivo, o vestibular. (TELLES, 2004, p. 159; JOHNSON, 2003, p. 2-3) Tradicionalmente, no Brasil, o ingresso na universidade baseou-se apenas no exame do vestibular e as notas do ensino médio eram completamente desconsideradas. Por haver uma concorrência maior para um número reduzido de vagas, alguns alunos, normalmente aqueles com mais recursos financeiros, pagam por um ano de curso preparatório para o vestibular (cursinhos). (JOHNSON, 2003, p. 2-3) O vestibular tem o objetivo de testar o conhecimento substancial de todos os anos de estudo, porém é comum o vestibular testar conteúdo que não foi ensinado nas escolas públicas de ensino fundamental e médio. (JOHNSON, 2003, p. 3; CESAR, 2003, p. 294-295)

Consequentemente, as melhores universidades, ou seja, as públicas, são frequentadas desproporcionalmente por brasileiros brancos cujos pais pagaram pelas melhores escolas na formação básica e média. (TELLES, 2004, p. 124) 
A maioria dos afrodescendentes, que tem recursos limitados, é excluída das universidades públicas de elite e relegada a pagar por escolas privadas ou a parar de estudar. (TELLES, 2004, p. 124; GUIMARÃES, 2003, p. 75-77) Como resultado, no ano de 2010, o Ministério da Educação divulgou que apenas 2\% de todos os estudantes universitários no país eram negros. (CARVALHO, 2001, p. 13-30, 17) Ainda pior, a representatividade de afro-brasileiros era praticamente nula em programas acadêmicos de elite, como medicina e direito. Grupos afrodescendentes de defesa da justiça social criaram cursinhos para ajudar na preparação de estudantes excluídos, e também criaram uma universidade para negros - Faculdade Zumbi dos Palmares (FAZP) -, uma vez que os mesmos acreditam que, sozinhos, os estudantes negros não conseguirão superar as deficiências do ensino público de má qualidade, o que acarreta sua exclusão do ensino superior. (NASCIMENTO, 1999) A política desse padrão demográfico no ingresso à universidade foi o que incentivou os movimentos negros a reivindicarem políticas de ação afirmativa nas universidades. (TELLES, 2004, p. 59, 253)

O fato de o debate público sobre programas de ação afirmativa baseados em raça ter enfrentando resistência difere da facilidade com que as ações afirmativas de gênero foram introduzidas no país alguns anos antes. (HTUN, 2004) Em 1995, o Brasil adotou cotas para mulheres no sistema eleitoral. O artigo 11 da Lei $\mathrm{n}^{\circ}$ 9.100/95 estabeleceu que, pelo menos, 20\% dos candidatos nas eleições municipais legislativas deveriam ser mulheres. Já a Lei nº 9.504/97 estabeleceu uma cota de $25 \%$ para as candidaturas a cargos no legislativo estadual e federal. Com mais de uma década de experiência com tais políticas de ação afirmativa para mulheres, o discurso público nunca caracterizou essas políticas como uma forma de discriminação inconstitucional. Assim, fica evidente que a objeção da elite brasileira às políticas de ação afirmativa baseadas em raça não é uma objeção às ações afirmativas propriamente, mas à natureza racial dessas ações.

Isso também é enfatizado pelo fato de que outras políticas de ação afirmativa não baseadas em raça não causaram discórdia da opinião pública. Programas de ação afirmativa voltados para filhos de fazendeiros e para deficientes foram criados antes das políticas baseadas em raça. Por exemplo, a Lei n ${ }^{0} 5.465 / 68$ instituiu cotas para proporcionar acesso de filhos de fazendeiros à educação superior. (CESAR, 2003, p. 26-32) Para os portadores de deficiência, a Constituição Federal de 1988, artigo 37, VIII, estabelece que a lei reservará um percentual dos cargos e empregos públicos para as pessoas portadoras de deficiência e definirá os critérios de sua admissão. A implementação desse dispositivo 
resultou em várias leis que determinam cotas para pessoas com deficiência no serviço público (Lei n ${ }^{\circ} 8.112 / 90$ ) e no setor privado (Lei n ${ }^{\circ} 8.213 / 91$ ).

Mesmo aqueles que, em princípio, supostamente apoiam programas de ação afirmativa baseados em raça questionam se eles podem ser implementados adequadamente em um país de pessoas "miscigenadas", que possuem identidades raciais fluidas e ambíguas. A preocupação com reivindicações fraudulentas feitas por brasileiros brancos foi levada em conta por ocasião da estruturação de programas de ação afirmativa voltados para candidatos que se autodeclarassem negros, uma vez que "a categoria negro tende a intimidar os oportunistas". (BERNARDINO-COSTA, 2007, p. 281-296, 283) A lógica é que, enquanto o discurso de democracia racial brasileira romantiza a noção de conexões remotas com ancestrais africanos, não diminui as associações pejorativas com uma identidade negra. Apesar disso, a questão das reivindicações fraudulentas existe e foi enfrentada de várias formas, que incluem a solicitação de documentação oficial com dados raciais, solicitação de fotografias para verificar a identidade racial, entrevistas com os candidatos, verificação da renda familiar e uso de informações indiretas sobre raça oriundas das escolas de educação básica frequentadas. (RACUSEN, 2009)

Por sua vez, críticos das ações afirmativas questionam a eficácia dos programas e alegam que irão reduzir a qualidade do ensino universitário. O subtexto explícito é que a ação afirmativa é uma importação imperialista desastrosa que não pode ser aplicada efetivamente em um contexto racial latino-americano, como o brasileiro. (BOURDIEU; WACQUANT, 2002, p. 15-33) Em outras palavras, a história racial da legislação Jim Crow dos Estados Unidos e a consequente estrutura racial rígida são tão estranhas ao contexto latino-americano que a "ação afirmativa estadunidense" não tem lugar no Brasil nem em qualquer outro lugar da América do Sul. Essa crítica ignora a cumplicidade histórica dos Estados latino-americanos por meio do direito costumeiro de regulação racial e chega ao ponto de situar a América Latina como uma região "racialmente inocente" e onerada excessivamente com uma reivindicação por justiça racial descabida.

Entretanto, não somente os gestores brasileiros têm encontrado seus próprios mecanismos para administrar programas de ação afirmativa baseados em raça, como também pesquisas mostram que os resultados dos estudantes cotistas demonstram que os programas são um sucesso. Por exemplo, um estudo dos resultados dos estudantes na Universidade Estadual de Campinas (Unicamp) descobriu que estudantes que cresceram em situação socioeconômica e educacional desvantajosa tiveram desempenho relativamente melhor na universidade 
do que aqueles de níveis socioeconômico e educacional mais alto. (PEDROSA et al., 2007, p. 1-20) O estudo concluiu que a necessidade de trabalho duro ao lutar por mais oportunidades (como estudar para o vestibular mesmo sem preparação adequada no ensino médio das escolas públicas) cria uma "resiliência acadêmica" que melhora o desempenho, uma vez que o estudante é admitido na universidade. (PEDROSA et al., 2007, p. 13) Na Unicamp, o programa de ação afirmativa aloca pontos adicionais para o exame de admissão com base na origem educacional dos estudantes (nesse caso, afrodescendentes pobres predominam) e na condição de ser negro ou indígena. A "resiliência acadêmica" dos estudantes menos privilegiados foi manifestada diretamente nas maiores notas dos estudantes cotistas logo depois do primeiro ano de estudos em 31 dos 35 cursos de graduação. No todo, o desempenho relativo dos estudantes cotistas foi maior em 48 dos 55 cursos.

De modo similar, na UnB, onde $20 \%$ das vagas são reservadas para estudantes negros, dois terços ou mais dos cursos não apresentaram significativas diferenças entre os estudantes cotistas e os não cotistas. (VELLOSO, 2009, p. 621-644) De fato, na turma de 2005, os estudantes cotistas tinham notas mais altas em $55 \%$ dos 33 cursos. Em 2008, foi observado que estudantes cotistas negros em 27 cursos da UnB tinham notas mais altas que os outros estudantes da universidade. (CARDOSO, 2008) O estudo dos estudantes da UnB apontou que essa foi uma tendência também observada em outras universidades brasileiras. De fato, os estudantes cotistas que se matricularam em 2003 na Universidade Estadual do Norte Fluminense (UENF) tinham notas comparáveis aos outros estudantes e, em pelo menos cinco cursos, as notas eram superiores. (BRANDÃO; DA MATTA, 2007, p. 46-80) Por ocasião do vestibular de 2003, o programa de ações afirmativas reservou vagas para estudantes oriundos de escolas públicas, negros e indígenas.

Na Universidade Federal da Bahia (UFBA), os estudantes, cotistas e não cotistas, dos cursos mais prestigiosos e concorridos (como direito e medicina) tiveram desempenho semelhante. (QUEIROZ; SANTOS, 2006, p. 717-737) O programa de ação afirmativa das UFBA reserva vagas para estudantes oriundos de escolas públicas, negros e indígenas. Além disso, há vagas destinadas a estudantes brancos oriundos de escolas públicas. Quando há vagas, estudantes negros oriundos de escolas particulares também podem participar. Em 11 dos 18 cursos mais concorridos da UFBA, $61 \%$ dos estudantes cotistas obtiveram notas maiores ou iguais às notas dos demais estudantes.

De modo similar, um estudo da UERJ mostrou que na primeira turma de estudantes de medicina que contava com cotistas, graduados em 2010, não havia 
diferenças de desempenho acadêmico, desistência e sucesso nos exames de admissão aos programas de residência entre os cotistas e os não cotistas. (VIEIRA, 2011) O programa de ação afirmativa da UERJ reserva vagas para estudantes de baixa renda, oriundos de escolas públicas, negros, indígenas, deficientes e filhos de policiais falecidos.

Ademais, um estudo sobre a desistência estudantil na Universidade Federal do Espírito Santo (UFES) mostrou que há uma taxa geral de desistência mais baixa entre os estudantes cotistas se comparada à dos não cotistas. (FORD, 2011, p. 67-68) Mesmo universidades privadas que instituíram programas de ação afirmativa têm obtido resultados bastante positivos. Por exemplo, na Pontifícia Universidade Católica do Rio de Janeiro (PUC-RJ), a maioria dos estudantes cotistas se encontram entre os $10 \%$ dos melhores alunos. (TREVIÑO GONZÁLEZ, 2010, p. 132) Além disso, um estudo do governo sobre o ProUni mostrou que a taxa de desistência dos estudantes bolsistas na zona oeste do Rio de Janeiro foi similar à média nacional. (AMARAL; OLIVEIRA, 2011, p. 21-42)

Em suma, o uso bem-sucedido de políticas de ação afirmativa no Brasil pode servir como uma inspiração para que outros países latino-americanos também melhorem antigos padrões de desigualdade racial em meio à retórica oposicionista que acredita na existência de uma democracia racial. Mais especificamente, assim como o resto da América Latina, o Brasil tem encontrado resistência às ações afirmativas sob o argumento de que a fluidez da identidade racial e a mistura racial iriam impedir a efetiva implementação dessas políticas. A esse respeito, uma análise do discurso brasileiro de miscigenação racial e formação da identidade pode oferecer mais elementos para países latino-americanos que buscam superar os obstáculos ideológicos e raciais às ações afirmativas. A afirmação da identificação racial nos censos oficiais oferece um marco analítico útil para se discutir como as presunções latino-americanas sobre fluidez racial podem coexistir com a prescrição de uma ordenação racial, de modo que as políticas de ação afirmativa possam ser implementadas efetivamente.

\section{Os desafios do recenseamento e de identidade para o cumprimento do direito antidiscriminatório}

Tendo em vista como, ao longo da história, o Estado tem manipulado os dados do censo relativos à raça para sub-representar a presença de pessoas de ascendência africana no Brasil (como detalhado nos capítulos 2 e 3), as organizações 
brasileiras de justiça racial têm buscado atuar mais diretamente nas maneiras pelas quais o discurso da suposta democracia racial impede uma averiguação precisa da demografia racial. No Brasil, os últimos censos usaram os termos para cor: "branco", "amarelo", "pardo" e "negro". Embora os censos regulares brasileiros usem o termo cor, as categorias de cor utilizadas correspondem diretamente a categorias raciais. A cor amarela destina-se à categoria racial "asiático", enquanto a cor negra se refere a pessoas de ancestralidade africana, "pardos" representa as pessoas com ancestralidade africana e europeia. A única categoria racial explícita no censo brasileiro de 1991 foi a “indígena”, em referência às populações nativas.

Demógrafos notaram que desde que o censo brasileiro instituiu a autodeclaração para coletar dados raciais em 1950, um número significativo de indivíduos mudou sua classificação racial de um censo para o outro. As alterações raciais apresentam um padrão específico, qual seja, uma grande parte das pessoas que se classificaram como negros, no censo de 1950, reclassificou-se como pardo no censo de 1980. (CARVALHO et al., 2004, p. 331-343) Padrões de reclassificação similares ocorreram nos recenseamentos dos anos seguintes.

Estudos sociológicos de outros conjuntos de dados no Brasil, com dados raciais tanto dos respondentes como dos entrevistadores, examinaram mais de perto a prática da fluidez na classificação racial e notaram que o "embranquecimento" corresponde a um padrão muito específico. Em um estudo de Edward Telles, $79 \%$ das vezes entrevistadores e respondentes escolheram inequivocamente a mesma classificação de cor para o respondente. (TELLES, 2002, p. 415-441) Enquanto as pessoas que se encontram na parte mais clara do espectro de cor tendem a ser classificadas de forma consistente, a ambiguidade é maior entre as pessoas que estão no lado mais escuro do espectro de cor. Mas até a ambiguidade tem seus limites. Entrevistadores tendem a embranquecer a classificação de pessoas com alto grau de educação formal e autodeclaradas pardas, em especial quando elas vivem em regiões com predominância de negros.

Em contraste, existe muito mais consistência na classificação de brancos que vivem em regiões com predominância de brancos. Ademais, o alto grau de escolaridade tem o mesmo efeito branqueador. No caso dos homens mais escuros, todavia, o alto nível de educação formal não altera a classificação de cor. São as pessoas mais claras que vivem em áreas com predominância não brancas as que apresentam maior tendência de branqueamento. Em resumo, o discurso da 
democracia racial, teoricamente, permite a qualquer pessoa se embranquecer, mas, na prática, as normas sociais predeterminadas limitam essa possibilidade. Pareceria que apenas em regiões onde poucos "brancos de verdade" vivem (como o Nordeste), os afrodescendentes de pele clara e alto grau de educação formal estariam socialmente permitidos a se embranquecerem estatisticamente. Quando os "brancos de verdade" predominam em uma região (como o Sul), existe pouca flexibilidade para pessoas visivelmente afrodescendentes se embranquecerem, independentemente da tonalidade de sua pele ou situação educacional. Esse padrão é ainda mais forte para homens afrodescendentes, talvez como resultado da sexualização das mulheres afro-brasileiras em combinação com o emprego ostensivo de estratégias para parecerem brancas, como alterações no cabelo, maquiagem e delineadores de lábios. (CALDWELL, 2007, p. 59-65, 90-106)

Similarmente, o embranquecimento intergeracional de crianças segue um padrão racializado específico. A Pesquisa Nacional de Amostragem por Domicílio do Instituto Brasileiro de Geografia e Estatística, em 2005, mostrou que um pai ou mãe não brancos, com ensino médio ou fundamental, provavelmente não embranquecerá sua criança tida com um(a) parceiro(a) branco(a). (SCHWARTZMAN, 2007, p. 940-963) Em geral, é nos raros casamentos inter-raciais entre pessoas com alto grau de educação formal que uma criança é embranquecida. Os casamentos inter-raciais, por si só, não garantem a regra de "uma gota de sangue branco" para embranquecer uma criança mestiça. Mas é o nível educacional de um casal inter-racial que facilita o embranquecimento.

Os estudos da maleabilidade das categorias de raça e cor no Brasil demonstram que outros fatores, que não a raça, também influenciam a escolha da categorias de "cor" no censo, constatando-se que a efetiva fluidez racial é restrita às pessoas de pele mais clara com alto nível educacional. Para aquelas com inequívoca pigmentação e características branca ou negra, a classificação racial é mais fixa e polarizada. De fato, mesmo aqueles estudos que examinam a grande quantidade de categorias informais de cor que existem no Brasil têm concluído que, na prática, as variações estão todas centradas na tentativa de denotar mistura racial, ao mesmo tempo em que mantêm polarizados os significados de branquitude e negritude. (SANJEK, 1971, p. 1126-1143; SILVA, 1996, p. 79-95)

Por essa razão, os ativistas brasileiros que lutam pela justiça social promoveram uma campanha, em 1991, pela inclusão de uma categoria específica para designar ancestralidade africana em detrimento de uma categoria de cor mestiça. (NOBLES, 2000, p. 146-162) Embora a solicitação para eliminar a categoria 
racial "mestiça" tenha sido rejeitada, os organizadores também promoveram uma campanha publicitária para encorajar os respondentes a evitarem a categoria "mestiça" e optarem pela categoria "negro". Essa campanha se chamava "Não deixe sua cor passar em branco: responda com bom senso", e o Instituto Brasileiro para Análises Sociais e Econômicas (Ibase), uma Organização Não Governamental que sistematicamente compila e distribui estatísticas sobre disparidades raciais no mercado de trabalho, ajudou a organizá-la. A campanha foi motivada pela preocupação que os brasileiros frequentemente apresentam sobre sua cor de pele, sendo que o desconforto de ter origens africanas faz com que os mesmos escolham categorias de cor mais claras por ocasião dos censos. A campanha por mais pessoas que escolhem a categoria "negro" de forma adequada foi montada para produzir dados socioeconômicos mais confiáveis sobre negros e, assim, ajudar na mobilização do movimento por justiça racial. Embora a campanha tenha sido bem-sucedida no que tange ao aumento da consciência do conteúdo político da identificação racial, as pessoas de descendência africana não optaram em massa pela categoria "negro" no censo. A incapacidade de reunir os recenseadores para uma sessão de treinamento sobre como abordar a questão raça e cor também pode ter atrapalhado a campanha.

O resultado do censo de 1991 apontou um leve aumento no número de brasileiros que usaram a categoria "pardo", em comparação aos números do censo de 1980, e uma leve diminuição no número de brancos. A categoria "negro" se manteve praticamente inalterada. (BRASIL, 1991) Ainda que em termos quantitativos a campanha tenha sido insignificante, seus organizadores alegam que foi uma vitória fazer com que os responsáveis pelo censo oficial brasileiro declarassem publicamente que repensariam as categorias de cor para os censos futuros, de modo a refletir o número de pessoas com ancestralidade africana de maneira mais precisa. (NOBLES, 1997)

Enquanto o censo de 2000 manteve as mesmas categorias de cor usadas nos anos anteriores, pela primeira vez em cinco décadas o número da população de pardos diminuiu, enquanto as populações branca e negra experimentaram um aumento. Em 2010, a população de pretos e pardos continuou a aumentar. A população negra aumentou de $6,2 \%$ para $7,6 \%$, enquanto a população de pardos aumentou de $38,4 \%$ para $43,1 \%$. Em contraste, os números da população branca diminuíram pela primeira vez desde que os censos começaram a ser realizados no Brasil, de 53,7\% da população, em 2000, para 47,7\% da população, em 
2010. O sociólogo Edward Telles sugere que as alterações censitárias nos percentuais de categoria de cor indicam que o "sistema de classificação racial brasileiro está se tornando cada vez mais bipolar" devido à influência do movimento negro e da globalização da cultura negra com a circulação mundial da música e filmes da diáspora africana, que encorajam uma identificação não ambígua com a negritude. (TELLES, 2004, p. 101) A reflexão de Telles também é corroborada por recentes estudos etnográficos que demonstram a crescente tendência de pessoas com ancestralidade africana no Brasil se identificarem como negras, realizando uma escolha política que reconhece a formação de uma identidade especificamente racial em resposta à consciência da discriminação racial. (CALDWELL, 2003, p. 40; SILVA, 2007, p. 69; FERREIRA, 2002, p. 69-86; HOSTEN, 2007, p. 21-29)

Além do mais, a promoção de uma identidade racial política negra não é exclusivamente o trabalho de movimentos por justiça social. Por exemplo, uma ala progressista da Igreja Católica no Brasil, a Pastoral Negra, está envolvida com a criação de uma consciência católica antirracista por meio de uma teologia, liturgia, prática pastoral, treinamento, oficinas e mídia. (BURDICK, 2004, p. 19, 48-53) Mesmo nas comunidades protestantes, que são comumente vistas como hostis às invocações de orgulho negro, etnógrafos encontraram comunidades de protestantes afrodescendentes e pobres devotos da escrava Anastácia, que formularam uma identidade negra empoderada pela figura histórica de uma escrava virtuosa (SHERIFF, 2001, p. 10) e o discurso de igualdade da Igreja Pentecostal. (BURDICK, 1998, p. 127-147, 161-180) Ademais, etnógrafos têm documentado, nas favelas do Brasil, não somente a existência de uma vibrante consciência racial negra entre os habitantes, mas também de um enfoque binário, em vez de uma abordagem racial fluida, como bem podemos ver na frase "Se você não passa por branco, você é preto". De fato, o uso de categorias de cor variáveis foi explicado pelos moradores da favela simplesmente como uma questão de cortesia universalmente aceita para manter a harmonia racial, ainda que haja um entendimento implícito de que "existem apenas duas raças” (SHERIFF, 2001, p. 58)

Como um acadêmico brasileiro declarou de modo franco:

Não há dificuldade intransponível em estabelecer um sistema padrão e funcional de classificação racial no Brasil porque nós nos classificamos voluntariamente como negro, branco, pardo, amarelo e indígena quando 
entrevistados pelos censos oficiais e também somos facilmente identificados com base nessas categorias por outros cidadãos, pela polícia e pelo sistema de justiça. Nós não temos problemas em saber quem é negro, pardo, branco, amarelo ou indígena. (SANTOS, 2006, p. 30-48)

Portanto, afirmações de que os brasileiros enfrentam problemas para se afirmar racialmente são um exagero.

Ao passo que é certo que a ideologia racial latino-americana do Brasil exalta as virtudes da suposta capacidade de ser flexível na hora de declarar a cor ou a identidade racial, essa exaltação coexiste com a capacidade de impor determinadas consequências àqueles identificados como não brancos. Por essa razão, Seth Racusen declarou acertadamente que "se numerosos atores públicos e privados podem rotineiramente tomar decisões discricionárias com propósitos discriminatórios, por que não seria possível para esses atores fazer determinações para promover políticas antidiscriminatórias?”. (RACUSEN, 2009, p. $89,92)$ O ponto de Racusen é que enquanto pode haver variação no modo com que os não brancos, que se parecem entre si, se identificam racialmente (negro versus pardo), o que é mais importante para a administração de uma política de ação afirmativa é a estrutura social que diferencia a condição de ser branco e a de não ser branco, com o propósito de influir no status social e nas oportunidades. Isso porque uma política de ação afirmativa procura interferir nas exclusões que configuram o status quo racial. A fluidez das categorias é irrelevante quando comparada ao significado da hierarquia racial particular, nas quais as categorias se alinham entre si. De fato, servidores públicos brasileiros têm administrado programas de ação afirmativa de forma criativa, operando em meio à fluidez racial por meio do recurso a várias combinações substitutas que indiquem a condição de não negro, tais quais ter cursado ensino médio em escola pública, ser de baixa renda, juntamente com autodeclaração racial de negritude, fotografias e entrevistas para determinar se os candidatos estão aptos a participar do programa. Por conseguinte, a afirmação de que ações afirmativas são uma importação imperialista dos EUA não pode efetivamente ser aplicada no contexto racial da América Ibérica, como o caso brasileiro tem mostrado. Desse modo, a experiência brasileira, até agora, deve servir como um importante guia para o resto da América Latina. 


\section{Conclusão: a conexão entre os Estados Unidos e a América Latina}

Assim como o racismo se tornou algo internacional, a luta contra o racismo também se tornou internacional. Uma só luta.

Malcolm X (MARABLE, 2011, p. 415)

Como na América Latina, o movimento pela justiça racial nos Estados Unidos chegou a um momento decisivo. Ainda que os mecanismos formais para lidar com a desigualdade racial existam e estejam sendo utilizados, há uma crença cada vez mais arraigada em parte da sociedade de que não se faz mais necessário o engajamento ativo do governo para garantir a igualdade racial. Segue havendo uma hierarquia racial que acompanha um compromisso social deteriorado com programas baseados em raça. O movimento estadunidense por direitos civis obteve um êxito espantoso ao fazer da meta da igualdade racial uma norma nacional expressa e ao catalisar programas governamentais voltados para promover acesso concreto ao trabalho e à educação. Entretanto, o próprio sucesso do movimento contribuiu para a ideia de que os negros e outras pessoas não brancas não mais necessitassem de assistência legal para obter oportunidades iguais. De fato, a eleição do presidente Obama, em 2008, é considerada como o ápice da superação da questão racial nos Estados Unidos, de modo que os 
Estados Unidos agora se apresentam como "racialmente inocentes", em um discurso muito similar ao discurso latino-americano. Ao mesmo tempo, o racismo sistêmico não foi erradicado, como evidenciado pelas persistentes disparidades raciais institucionalizadas nas relações de trabalho, na atenção à saúde, renda, segregação residencial e índices muito díspares na população carcerária e nos condenados a penas de morte.

Desse modo, a despeito das diferenças em termos de história, variação demográfica, estruturas jurídicas e modos de governança, as Américas têm em comum a luta contra o renitente legado da escravidão e contra os regimes de discriminação pós-abolicionistas. Ademais, as Américas agora compartilham os principais elementos de um discurso de "progresso racial" forjado no bojo de uma hierarquia racial sistêmica. Em outras palavras, a bem-sucedida luta dos movimentos por direitos civis contra a segregação da época Jim Crow agora coloca as minorias raciais estadunidenses em uma situação comparável à situação dos afrodescendentes na América Latina, os quais, por sua vez, lutam contra a hierarquia racial sem contar com um regime formal de discriminação institucionalizado como alvo nítido. Além do mais, o "pós-racialismo" nos Estados Unidos tem minimizado o compromisso com as leis e políticas de igualdade racial, porque despreza manifestações de desigualdade racial ao celebrar a igualdade formal e busca um modelo isento de "cor", fazendo com que preocupações com a questão racial sejam igualadas a atos de racismo. (CRENSHAW, 2011, p. 1253, 1256) Sem dúvida, isso em muito se assemelha com a tradicional abordagem de raça adotada na América Latina. Visto que a América Latina é uma região que tem se valido, por muito tempo, do discurso de que todas as distinções raciais deixaram de fazer sentido depois da abolição da escravidão, uma comparação com a versão latino-americana do "pós-racialismo", ou seja, a "democracia racial", é uma perspectiva muito útil para avaliar a viabilidade das afirmações contemporâneas do "pós-racialismo" nos Estados Unidos - o discurso que defende que o racismo já foi superado em grande parte. (CHO, 2009, p. 15891649) Como observa Anani Dzidzienyo, estudioso das relações raciais comparadas, examinar o contexto racial latino-americano "pode oferecer insights para os afro-estadunidenses que hoje estão tendo que confrontar presunções do pensamento hegemônico que alardeiam o 'fim do racismo' em uma sociedade estadunidense pós-direitos civis.” (DZIDZIENYO, 2005, p. 137-155)

O exame do contexto latino-americano também pode ser útil para os movimentos de justiça racial estadunidenses de hoje, se considerarmos o que o 
sociólogo Eduardo Bonilla-Silva (2002, p. 3-16) chama de a crescente "latino-americanização" da raça nos Estados Unidos. Bonilla-Silva usa a noção de "latino-americanização" para se referir ao que ele percebe como o uso crescente nos Estados Unidos de um método baseado na cor da pele, que obedece a uma "lógica pigmentocrática", para reorganizar o esquema de estratificação racial nos Estados Unidos, o qual está lentamente passando de uma estrutura birracial (branco/negro) para uma estrutura trirracial, mais frouxa e organizada em categorias gerais de branco, branco honorário e negro coletivo. A categoria de branco honorário é vista como uma categoria intermediária, como pessoas de cor na África do Sul ou mulatos na América Latina, assim designando pessoas brancas que podem se distinguir de afro-estadunidenses, mas que também não podem ser consideradas brancas. Os brancos honorários estariam em um patamar superior em relação à categoria mais depreciada dos negros coletivos. Bonilla-Silva prediz que, assim como na América Latina, os residentes nos Estados Unidos passarão a adotar identidades raciais baseadas na preferência eurocêntrica por uma cor de pele mais clara, mas irá proclamar que a raça não importa. Enquanto alguns acadêmicos não têm certeza sobre as previsões de Bonilla-Silva, o valor da sua análise reside no convite que faz para o estudo das semelhanças entre as mudanças de atitude em relação à raça nos EUA e às atuais construções latino-americanas. (SUE, 2009, p. 1058-1070; BONILLA-SILVA, 2002, p. 17-102; BONILLA-SILVA, 2009, p. 1071-1082)

A noção latino-americana de que a mistura racial transcende a ideia de raça e que a fluidez racial acaba com as barreiras raciais tem sido notada no discurso contemporâneo pós-racialista nos Estados Unidos, particularmente no que diz respeito aos recenseamentos e aos movimentos de identidade de pessoas multirraciais. Mais especificamente, as crescentes taxas de imigração, casamentos inter-raciais e crianças mestiças são rotineiramente utilizadas como a prova e a razão pela qual os programas racialmente sensitivos não são mais necessários. De fato, a crescente aceitação da mistura racial, e mais especificamente de identidades étnicas multirraciais, é considerada um grande desafio para a noção estadunidense de raça, que foi, implicitamente, tão central para os movimentos por direitos civis nos seus primeiros dias. Hoje, há um crescente reconhecimento acadêmico de que raça é um conceito socialmente construído e que a ancestralidade africana pode não necessariamente levar um indivíduo a assumir uma identidade racial negra ou considerar raça como algo socialmente relevante. 
A reconceituação de raça nos Estados Unidos se reflete na crescente transformação da crença de que as categorias raciais são estáticas e, portanto, que a identificação racial é clara e autoevidente em uma crença de que a miscigenação dissolverá a rigidez dessas categorias e bastará, sozinha, para incutir a harmonia racial na sociedade e até erradicar a necessidade de as pessoas se referirem umas às outras pela raça. (FERNÁNDEZ, 2007) As decisões da agência de recenseamento com o objetivo de permitir que as pessoas marquem múltiplas designações raciais nos formulários dos censos de 2000 e 2010, em vez da tradicional insistência na marcação de apenas uma categoria racial, é um exemplo contundente das mudanças em operação na ideologia racial estadunidense. Alguns demógrafos e sociólogos têm observado que essa definição racial mais matizada, viabilizada pela marcação de múltiplas designações raciais, pode ajudar a derrubar barreiras raciais. A noção de que o reconhecimento de uma identidade multirracial traria com ela, supostamente, o benefício de ofuscar as diferenças entre as várias cores, reduzindo assim as animosidades raciais. (GILANSHAH, 1993, p. 183-199) As atitudes latino-americanas em relação à raça, discutidas por tanto tempo, estão ecoando de modo desconcertante no discurso multirracial estadunidense. Por exemplo, a crença de que a miscigenação acabará com o racismo tem sido insistentemente apresentada para promover a ideia de que o censo deve levar em consideração a possibilidade de uma identidade racial mestiça. Os defensores do reconhecimento de uma categoria "multirracial" no censo, frequentemente afirmam que as pessoas multirraciais são uma "força unificadora" (ESTADOS UNIDOS, 1993), a partir de uma perspectiva de que pessoas multirraciais seriam "um grupo capaz de personificar a melhor chance que os EUA já teve de reformar as relações raciais”. (DOUGLASS, 1996, p. A26) De fato, a equiparação da mistura racial à harmonia racial é frequentemente explícita:

Eu defendo que a sociedade deve adotar, como um instrumento transitório, categorias raciais múltiplas, que expressamente reconhecem e dão crédito a pessoas oriundas de uniões inter-raciais, como algo distinto de negros e brancos. Eu afirmo que isso terá o efeito de criar um tipo de 'confusão de nuances' que eventualmente acabará com a dicotomia negro/branco que existe hoje e, em última instância, reduzirá a raça a uma categoria sem importância, como deve ser. (JOHNSON JUNIOR, 1996, p. 887-952)

Até Orlando Patterson, sociólogo de Harvard, concorda que "se o objetivo é a futura integração das raças, um grupo mestiço ou um grupo do meio é algo que 
você gostaria que se desenvolvesse. [...] Os grupos do meio vão crescendo, crescendo e, ao final, as raças se fundem." (MORGANTHAU, 1995, p. 63-65) Portanto, a narrativa do discurso multirracial afirma que, por meio da mistura, a nação será isentada da responsabilidade de lidar com as persistentes disparidades raciais em termos de oportunidades socioeconômicas. (CHEN, 1994, p. 145)

Contudo, uma demonstração ainda maior da nova noção racial nos Estados Unidos é o modo pelo qual o público tem recebido e se fixado nos resultados do censo de 2000. Embora apenas 2,4\% da população tenha escolhido de fato mais de uma categoria racial (JONES; SMITH, 2001, p. 1), o clamor público no que diz respeito ao potencial para fazê-lo é um indicador contundente de como a agência de recenseamento e o discurso sobre o censo tinham uma influência sobre a percepção pública. Por exemplo, o censo apontou a crescente diversidade racial de muitas cidades e a mídia observou que as mudanças demográficas "transformarão não somente a cidade, mas também alterarão o modo como os estadunidenses pensam sobre raça, ajudando-os a pensar além dos simples conceitos de branquitude e negritude". (FRIEDMAN, 2001, p. 6) Kenneth Prewitt, o ex-diretor da agência de recenseamento, concluiu que a disponibilidade de múltiplas categorias raciais para uma demografia crescentemente mestiça é "um sinal saudável de que as barreiras estão se quebrando. [... É É uma indicação não apenas da complexidade, mas também da fluidez da composição da nossa população.” (CHENG, 2001, p. E6) ${ }^{1}$ Além disso, a antecessora de Prewitt, Martha Farnsworth Riche, comentou que os resultados do censo de 2000 marcam "o começo do fim do papel dominante da raça em nossa vida pública.” (KASINDORF; EL NASSER, 2001, p. 1A)²

Até alguns ativistas de direitos humanos concordam com a avaliação de que as mudanças demográficas significam que já "estamos nos deslocando para além de um paradigma racial negro e branco," (SCHMITT, 2001, p. A1) 3 e que "quanto mais misturados somos, mais provável é que nós sejamos sensíveis uns aos outros.” (KASINDORF; EL NASSER, 2001, p. 1A)4 De modo similar, alguns

1 Em que se cita Prewitt.

2 Em que se cita Riche.

3 Em que se cita Sonia M. Pérez, vice-presidente executiva do National Council of La Raza, uma organização ativista em prol dos hispanos.

4 Em que se cita Beatriz López-Flores, vice-presidente do Mexican-American Legal Defense and Educational Fund. 
demógrafos e sociólogos concluíram que "quanto mais nuances" forem admitidas na identificação racial, por meio das múltiplas designações raciais, "mais se contribuirá para destruir as barreiras raciais.” (SCHMITT, 2001, p. A1) Além do mais, em uma pesquisa nacional realizada depois do lançamento público dos dados do censo de 2000, 64\% dos respondentes declararam que "seria 'bom para o país' ter mais estadunidenses 'se identificando como multirraciais em vez de pertencentes a um único grupo racial”'. (KASINDORF; EL NASSER, 2001) Ao informar sobre a pesquisa, o USA Today observou que: "As divisões raciais podem ser superadas até que o melting pot [caldeirão cultural] idealizado pelo escritor Israel Zangwill, em 1908, torne-se uma harmoniosa realidade do tipo 'We Are The World.” (KASINDORF; EL NASSER, 2001) À fala anterior foi seguida da exclamação de um policial: "e a gente vai odiar quem?".

A emergência de um discurso pós-racial ao estilo latino-americano nos Estados Unidos também é observada em decorrência do crescente número de indivíduos que não acha mais que racismo seja um problema (FEAGIN, 2000, p. 96), e em decorrência do abandono do critério de raça pelo judiciário, que busca um critério "indiferente à cor" porque raça é um assunto tabu cuja mera menção constitui um ato de racismo. Essas visões estão presentes na declaração do ministro da Suprema Corte estadunidense, Antonin Scalia: "Aos olhos do governo, há apenas uma raça aqui. É a raça americana”. (ESTADOS UNIDOS, 1995) Além do mais, assim como em várias campanhas de promoção da identidade nacional em países latino-americanos, os cidadãos estadunidenses estão sendo encorajados a se enxergarem como "simplesmente estadunidenses", em vez de se identificarem a partir de classificações étnicas ou raciais, prática que é considerada, por si mesma, segregadora. De fato, até os ataques às tentativas norteadas pelo conceito de raça de facilitar a participação político-eleitoral na distribuição das zonas eleitorais têm sido interpretados como a preocupação de não "estimular $[\ldots]$ a consciência pública da raça" e, portanto, "alimentar [...] as chamas da divisão racial.” (SAUNDERS, 2001, p. 1367-1382)

Contudo, até agora, a diluição das raças nos Estados Unidos conserva uma perspectiva claramente pejorativa, que se assemelha ao desprezo latino-americano pela negritude, juntamente com a celebração da mistura racial. É verdade que as taxas de casamento inter-raciais nos Estados Unidos têm aumentado enormemente com o passar dos anos, com cerca de um casamento inter-racial ou interétnico a cada sete casamentos em 2008, representando, portanto, o dobro da taxa de casamento interétnico da década de 1980 e seis vezes a taxa de 
casamento interétnico da década de 1960. (PASSEL; WANG; TAYLOR, 2010) Contudo, casais compostos por uma pessoa branca e outra negra representam o menor número dentre os casamentos interétnicos e as mulheres negras têm a menor taxa de participação em casamentos interétnicos. Ao passo que as altas taxas de encarceramento de homens negros fazem com que as mulheres negras tenham menos homens negros com quem se casar, também é verdade que as mulheres negras, seguidas dos homens negros, são consideradas as parceiras menos desejáveis para outras raças e grupos étnicos. (BANKS, 2011) Assim, ainda que estudos recentes indiquem que homens asiáticos são os menos desejados por mulheres brancas em sites de namoro, a tendência de recusar o casamento com homens negros persiste. (FELICIANO; ROBNETT; KOMAIE, 2009, p. 39-54) Além do mais, o desprezo pelas mulheres negras também se estende ao mundo do namoro na internet, no qual as mulheres negras são consideradas as opções menos desejadas para os homens brancos.

Quando pessoas negras se envolvem em relações inter-raciais, seus filhos encontram maior resistência social ao declarar uma identidade multirracial que a encontrada por outros indivíduos racialmente miscigenados que se identificam como multirraciais. Especificamente, no estudo de Lee e Bean sobre identidade multirracial entre pessoas mestiças, descobriu-se que as identidades multirraciais são mais prontamente aceitas quando expressas por branco-asiáticos e branco-latinos que por branco-negros. (LEE; BEAN, 2007, p. 561-586) Além disso, eles também contam com maior aceitação social quando afirmam uma identidade racial branca com ou sem uma identidade cultural étnica. O estudo observou que as experiências de latinos e asiáticos com multirracialidade estão mais próximas das experiências dos imigrantes europeus que, num primeiro momento foram racializados e, com o passar do tempo, puderam lidar com suas filiações étnicas como opção própria. O contexto multirracial dos asiáticos e latinos sugere um afrouxamento das fronteiras raciais para decidir se, quando e como eles escolherão se identificar racialmente, situação que não é possível para os indivíduos negros multirraciais.

Além disso, para muitos latinos nos Estados Unidos, que são em regra identificados como pessoas intrinsicamente multirraciais, a branquitude continua a ser a categoria racial escolhida. (DARITY JUNIOR et al., 2005, p. 103-109; EL NASSER, 2011) Por exemplo, quando se deu a possibilidade de escolher mais de uma categoria racial no censo de 2010, 94\% dos latinos escolheram uma única categoria racial e a categoria isolada escolhida por 53\% dos latinos 
foi "branca". (ESTADOS UNIDOS, 2010) Os 36,7\% dos latinos que selecionaram o campo "outra raça", aparentemente o fizeram como mecanismo para indicar que possuem ancestralidade indígena, visto que a maioria dos latinos que escolheram essa última categoria era da América Central, mas podem ter se sentido excluídos pela categoria racial do censo "indígena estadunidense", que remete a filiações tribais oficialmente reconhecidas. Apenas 2,5\% dos latinos escolheram a categoria racial "negra". Quando imigrantes latinos recém-chegados foram perguntados individualmente, $79 \%$ escolheram uma única categoria, "branco", independentemente da cor da pele. (GRIECO, 2010; FRANK; AKRESH; BO LU, 2010, p. 378-401)

Em contraste, o construto racial continua a ser imposto às pessoas negras multirraciais, nesse sentido, Lee e Bean concluem que "não é simplesmente que a raça importa, mas, mais especificamente, que a raça negra importa, o que é coerente com a tese do excepcionalismo do afro-estadunidense". Isso sugere que, assim como na América Latina, a retórica pós-racialista de que somos todos um povo multirracial continua a fundamentar uma hierarquia racial e um preconceito contra negros. Como discutido nos capítulos 2 e 6 , a suposta fluidez da identidade racial latino-americana é desmentida por limitar-se a pessoas com pele mais clara e que tiveram acesso à educação superior. Para aqueles com pigmentação inequivocamente negra e características africanas, a classificação racial é mais fixa e polarizada.

É perturbador observar que, quando a mistura racial foi proposta como solução para o conflito racial na América Latina, o ônus de se misturar recaiu sobre os afrodescendentes. Com efeito, o branqueamento de negros, e não a miscigenação em si, tem sido um objetivo subjacente das campanhas de democracia na América Latina. E o resultado tem sido sempre a manutenção da supremacia branca. De fato, como o capítulo 2 demonstrou, a promoção de uma classe miscigenada na América Latina foi motivada pelo desejo de "embranquecer" os países, fazendo com que os negros desaparecessem por meio da miscigenação, sendo que a cor de pele é hierarquizada: a pele branca, a mais positivamente avaliada, e a pele negra, a menos desejada. O ideal de branqueamento "permanece codificado e intrincado na linguagem usada para designar "pessoas mestiças", geralmente representadas como pessoas "mais claras" ou até "mais brancas". (NOBLES, 1995, p. 112) Assim, a América Latina pós-racialista não superou a ideia da transcendência da raça, mas sim, reforçou a ideia de um sistema de castas raciais em uma região tradicionalmente considerada uma "democracia racial". 
O legado do mito da democracia racial e seu reforço na América Latina têm interferido negativamente na capacidade de os governos reconhecerem que coletar dados sobre raça pode ser uma ferramenta útil na promoção da igualdade racial. Mas a crescente pressão de ativistas afrodescendentes está começando a fazer com que os governos latino-americanos fiquem mais receptivos às políticas públicas que levam em conta a consciência de raça. De fato, o contexto latino-americano também ilustra como a resistência ao pós-racialismo pode ser possível mesmo depois de décadas de discurso pós-racialista. Os países latino-americanos estão deixando uma trajetória de defesa do mito da democracia racial em Estados com grandes populações afrodescendentes indigentes, e de marginalização de uma minoria invisível de afrodescendentes em países com grandes populações indígenas "mestiças", por uma nova, que implica, aos poucos, reconhecer a importância da raça e do racismo. (HTUN, 2004, p. 60-89) Em fevereiro de 2008, Belize elegeu, pela primeira vez, um primeiro ministro negro, Dean Barrow. Em 2007, Paula Moreno se tornou a primeira ministra negra colombiana em cinco décadas. Em 2003, o Brasil nomeou o primeiro ministro negro do Supremo Tribunal Federal. Em 1999, a Venezuela elegeu um presidente afrodescendente, Hugo Chávez. Tais posições de liderança desempenhadas por afrodescendentes são especialmente dignas de nota porque esses indivíduos se identificam abertamente como afrodescendentes. Isso contrasta bastante com a história latino-americana de ter líderes não brancos, com aparente ancestralidade africana, mas que nunca se identificaram racialmente de forma explícita (por exemplo: o presidente colombiano Juan José Gil, janeiro a julho de 1861; o presidente cubano Fulgêncio Batista, 1942-1952; o presidente dominicano Leonel Fernández Reyna, 1996-2000 e 2004-2012; o presidente hondurenho Manuel Bonilla Chirinos, 1903-1907 e 1912-1913; o presidente mexicano Vicente Guerrero, abril a dezembro de 1829; e o presidente peruano Luis Miguel Sánchez Cerro, 1930-1931). A existência de indivíduos que agora declaram abertamente serem afrodescendentes de forma afirmativa, e contrariam antigos estereótipos raciais depreciativos por meio da ocupação de posições de liderança, é um marco significativo do progresso racial na América Latina. Contudo, o discurso racializado que continua a permear a articulação das oposições de líderes, como Hugo Chávez, sugere que muito mais trabalho necessita ser feito antes que a verdadeira igualdade racial seja plenamente alcançada.

Levando em conta que a América do Sul e a América do Norte compartilham a mesma batalha contra insidiosos sistemas de hierarquia racial, é sensato 
que ambas as Américas olhem para além das diferenças superficiais de suas histórias jurídicas e, em vez disso, enfoquem os aspectos comuns ao respectivo legado histórico de escravidão e as suas consequências no contínuo esforço por parte da sociedade de disfarçar o privilégio por meio do discurso do mérito, da autossuficiência e cultura. Talvez seja pela combinação de esforços dos povos afrodescendentes das Américas que a justiça racial pode ser efetivada no cenário contemporâneo, caracterizado por um direito que se supõe racialmente neutro em uma complexa realidade racialmente díspare. Este livro busca oferecer uma leitura sobre como é possível sustentar as hierarquias raciais com ideologias e abordagens raciais aparentemente diferentes. Além do mais, a análise comparada das lutas dos afrodescendentes contra o racismo pode ser útil para aqueles que atuam na defesa da justiça racial nos Estados Unidos ao confrontar sua própria versão contemporânea "pós-racialista" com as ideologias raciais latino-americanas. Especificamente, os ativistas estadunidenses podem agora desvelar o pós-racialismo, ao compreender como um discurso similar nas demais Américas facilitou a desigualdade racial. Isso reflete os atuais interesses governamentais em esforços de cooperação transnacional em busca de justiça racial, a exemplo do Plano de Ação Colômbia-Estados Unidos para a Igualdade Racial e Étnica (2010) e o Plano de Ação Conjunta Brasil-Estados Unidos para a Eliminação da Discriminação Racial. Como afirmou o educador e defensor da justiça social, o brasileiro Paulo Freire (1987): "Ninguém liberta ninguém, ninguém se liberta sozinho. Os homens se libertam em comunhão.” 


\section{Referências}

\section{Fontes primárias}

\section{Decretos, leis e regulamentos}

ARGENTINA. Constitución (1853). Constitución de 1853. In: ARGENTINA. Constitución de la Nación Argentina: publicación del bicentenario. Buenos Aires:

Biblioteca Nacional, 2010. p. 31-54. Disponível em: <http://goo.gl/yIDqIL>. Acesso em: 20 jul. 2016.

ARGENTINA. Constitución (1994). Constitución de la Nación Argentina: publicación del bicentenario. Buenos Aires: Biblioteca Nacional. 2010. Disponível em: <http://goo.gl/yIDqIL>. Acesso em: 20 jul. 2016.

BOLÍVIA. Constitución (2009). Constitución Política del Estado Plurinacional de Bolivia. Gaceta oficial del Estado Plurinacional de Bolivia, La Paz, 2009. Disponível em: <http://goo.gl/Sr4MU3>.

BRASIL. Constituição (1934). Constituição da República dos Estados Unidos do Brasil. Diário Oficial da União, Rio de Janeiro, 1934, Seção 1, Suplemento. 
BRASIL. Constituição (1946). Constituição da República dos Estados Unidos do Brasil. Diário Oficial da União, Rio de Janeiro, 1946.

BRASIL. Constituição (1988). Constituição da República Federativa do Brasil. Brasília, DF, 1988.

BRASIL. Decreto-Lei n ${ }^{\circ} 2.848$, de 7 de dezembro de 1940. Código Penal. Diário Oficial da União Brasília, DF, 1940. Disponível em: <http://goo.gl/t0Tjp>. Acesso em: 20 jul. 2016.

BRASIL. Decreto ${ }^{\circ} 4.247$, de 6 de janeiro de 1921. Autoriza a Sociedade Nacional de Agricultura a alienar uma parte dos terrenos do Horto Frutícola da Penha e dá outras providências. Diário Oficial da União, Rio de Janeiro, 1921.

BRASIL. Decreto n ${ }^{\circ} 20.921$, de 25 de agosto de 1931. Autoriza a Sociedade Nacional de Agricultura a alienar uma parte dos terrenos do Horto Frutícola da Penha e dá outras providências. Diário Oficial da União, Rio de Janeiro, 1931. p. 13. BRASIL. Lei ${ }^{\circ} 1.390$, de 3 de julho de 1951. Inclui entre as contravenções penais a prática de atos resultantes de preconceitos de raça ou de côr. Diário Oficial da União, Rio de Janeiro, 10 jul. 1951.

BRASIL. Lei $n^{\circ} 7.347$, de 24 de julho de 1985. Disciplina a ação civil pública de responsabilidade por danos causados ao meio-ambiente, ao consumidor, a bens e direitos de valor artístico, estético, histórico, turístico e paisagístico (VETADO) e dá outras providências. Diário Oficial da União, Brasília, DF, 25 jul. 1985.

BRASIL. Lei $\mathrm{n}^{\circ}$ 7.716, de 5 de janeiro de 1989. Define os crimes resultantes de preconceito de raça ou de cor. Diário Oficial da União, Brasília, DF, 9 jan. 1989.

BRASIL. Lei n ${ }^{\circ} 8.081$, de 21 de setembro de 1990. Estabelece os crimes e as penas aplicáveis aos atos discriminatórios ou de preconceito de raça, cor, religião, etnia ou procedência nacional, praticados pelos meios de comunicação ou por publicação de qualquer natureza. Diário Oficial da União, Brasília, DF, 24 set. 1990.

BRASIL. Lei n ${ }^{\circ}$ 9.394, de 20 de dezembro de 1996. Estabelece as diretrizes e bases da educação nacional. Diário Oficial da União, Brasília, DF, 23 dez. 1996.

BRASIL. Lei n ${ }^{\circ}$ 9.459, de 13 de maio de 1997. Altera os arts. $1^{\circ}$ e 20 da Lei ${ }^{\circ} 7.716$, de 5 de janeiro de 1989, que define os crimes resultantes de preconceito de raça ou de cor, e acrescenta parágrafo ao art. 140 do Decreto-lei n ${ }^{\circ} 2.848$, de 7 de dezembro de 1940. Diário Oficial da União, Brasília, DF, 14 maio 1997. 
BRASIL. Lei ${ }^{\circ}$ 12.288, de 20 de julho de 2010. Institui o Estatuto da Igualdade Racial; altera as Leis nos 7.716, de 5 de janeiro de 1989, 9.029, de 13 de abril de 1995, 7.347, de 24 de julho de 1985, e 10.778, de 24 de novembro de 2003. Diário Oficial da União, Brasília, DF, 21 jul. 2010a.

BRASIL. Medida provisória n ${ }^{\circ}$ 2.102-28, de 23 de fevereiro de 2001. Acresce e altera dispositivos das Leis $n^{\circ}$ s 8.437, de 30 de junho de 1992, 9.028, de 12 de abril de 1995, 9.494, de 10 de setembro de 1997, 7.347, de 24 de julho de 1985, 8.429, de 2 de junho de 1992, 9.704, de 17 de novembro de 1998, do Decreto-Lei $\mathrm{n}^{\circ} 5.452$, de $1^{\circ}$ de maio de 1943, das Leis $\mathrm{n}^{\circ} \mathrm{s} 5.869$, de 11 de janeiro de 1973, e 4.348, de 26 de junho de 1964, e dá outras providências. Diário Oficial da União, Brasília, DF, 26 fev. 2001. Seção 1 - Eletrônico. p. 8.

BRASIL. Ministério da Fazenda. Circular nº 29, de 14 de maio de 1891. Diário Oficial da União, Rio de Janeiro, 1891.

CHILE. Constitución (1980). Constitución Política de la República de Chile. Ministerio Secretaría General de la Presidencia, Santiago de Chile, 8 ago. 1980. Disponível em: <https://goo.gl/5Lvbxc>. Acesso em: 20 jul. 2016.

COLÔMBIA. Constitución (1995). Constitución Política de Colombia. In: FLANZ, G. H. 4 Constitutions of the Countries of the World. Tradução de Peter B. Heller e Marcia W. Coward. Release 95-4, 1995. Dobbs Ferry: Oceana Publications, [1995?]. COLÔMBIA. Corte Constitucional. Sentencia T-025/04. Bogotá, 2004. Disponível em: <http://goo.gl/dofbNq>. Acesso em: 20 jul. 2016.

COLÔMBIA. Decreto 1122, de 18 de junio de 1998. Diario Oficial de Colombia, Bogotá, 18 jun. 1998.

COLÔMBIA. Ley 115, de 8 febrero de 1994, art. 160, §10. Diario Oficial de Colombia, Bogotá, 8 fev. 1994.

COSTA RICA. Constitución (1949). Constitución Política de la República de Costa Rica (con reformas de 2003). Disponível em: <http://goo.gl/WnKIXq>.

CUBA. Constitución (1992). Constitución de la República de Cuba. Gaceta Oficial de la República de Cuba, La Habana, 1992. Disponível em: <http://goo.gl/11nDKd>. Acesso em: 20 jul. 2016. 
EL SALVADOR. Constitución (1983). Constitución de la República. Diario Oficial de El Salvador, San Salvador, 16 dez. 1983. Disponível em: <http://goo.gl/SB0bGU>. Acesso em: 20 jul. 2016.

EQUADOR. Constitución (2008). Constitución de la República del Ecuador. Registro Oficial de Ecuador, Quito, 20 out. 2008. Disponível em: <http://goo.gl/ uwtuQ>.

ESTADOS UNIDOS. Gentlemen's Agreement. 1907.

ESTADOS UNIDOS. Immigration Act of 1917, ch. 29, 39 Stat. 874, 1917.

ESTADOS UNIDOS. Immigration Act of 1924, ch. 190, 43 Stat. 153, 1924.

GUATEMALA. Constitución (1985). Constitución Política de la República de Guatemala, 1985 (con 1993 reformas). Ciudad de Guatemala, 31 maio 1985.

Disponível em: <https://goo.gl/UIAFMx>. Acesso em: 20 jul. 2016.

HONDURAS. Constitución (1982). Constitución Política de Honduras. La Gaceta, Tegucigalpa, 20 jan. 1982. Disponível em: <http://goo.gl/xsQJRa>. Acesso em: 20 jul. 2016.

HONDURAS. Decreto ejecutivo PCM 09-2007. Diario Oficial La Gaceta De La Republica De Honduras, Tegucigalpa, 30 Abril 2007.

INTER-AMERICAN COMMISSION ON HUMAN RIGHTS. Basic Documents Pertaining to Human Rights in the Inter-American System. Organization of American States, Washington, DC, 2003. Disponível em: <http://goo.gl/2YQ1RU>. Acesso em: 20 jul. 2016.

MÉXICO. Constitución (1917). Constitución Política de los Estados Unidos Mexicanos (1917 com reformas de 2008). Diario Oficial de la Federación, Ciudad de México, 5 fev. 1917. Disponível em: <http://goo.gl/RyD0Pm>. Acesso em: 20 jul. 2016.

NICARÁGUA. Código Penal. La Gaceta, Manágua, 13 nov. 2007. Disponível em: <https://goo.gl/BWQnJt>. Acesso em: 20 jul. 2016.

NICARÁGUA. Constitución (1998). Constitución Política de la República de Nicaragua con sus Reformas Incorporadas. La Gaceta, Manágua, 18 fev. 2014. Disponível em: <http://goo.gl/xfhpQC>. Acesso em: 20 jul. 2016. 
PANAMÁ. Constitución (1995). Constitución Política de la República de Panamá. Gaceta Oficial, Ciudad de Panamá, 15 nov. 2004. Disponível em: <http://goo.gl/ uiIVWv>. Acesso em: 15 nov. 2004.

PARAGUAI. Constitución (1992). Constitucion de la Republica del Paraguay. Asunción, 20 jun. 1992. Disponível em: <http://goo.gl/nTwZvc>. Acesso em: 20 jul. 2016.

PERU. Constitución (1993). Constitución Política del Perú de 1993. Disponível em: <http://portal.jne.gob.pe/informacionlegal/Constitucin $\% 20 y \% 20$ Leyes $1 /$ CONSTITUCION\%20POLITICA\%20DEL\%20PERU.pdf>.

PERU. Decreto Ley n ${ }^{\circ}$ 25868, 6 de noviembre de 1992. Ley de Organización y Funciones del Instituto Nacional de Defensa de la Competencia y de la Protección de la Propiedad Intelectual (Indecopi). Lima, 18 nov. 1992. Disponível em: <http://goo. gl/fYNgHz>. Acesso em: 20 jul. 2016.

PERU. Decreto Supremo 003-97-TR. Lima, 27 mar. 1997. Disponível em: <http:/| goo.gl/McZem>. Acesso em: 20 jul. 2016.

PERU. Ley 26772, 1997. Casa de Gobierno, Lima, 14 abr. 1997. (Modificada por la Ley 27270, 2000). Disponível em: <http://goo.gl/hQ2PGK>.

PERU. Ley 27270, 2000 (Ley contra Actos de Discriminación). Casa de Gobierno, Lima, 26 maio 2000. Disponível em: <http://goo.gl/3EAxAy>.

PERU. Resolución Suprema n. 010-2009-MIMDES, 27 de noviembre de 2009. El Peruano, Lima, 28 nov. 2009. Disponível em: <http://goo.gl/oXzHlm>. Acesso em: 20 jul. 2016.

REPÚBLICA DOMINICANA. Constitución (2002). Constitución de la República Dominicana. Gaceta Oficial, Santo Domingo de Guzmán, 17 nov. 2003. Disponível em: <http://goo.gl/2zjboi>.

REPÚBLICA DOMINICANA. Ley 24-97. Que introduce modificaciones al código penal, al código de procedimiento criminal y al código para la protección de niños, niñas y adolescentes. Secretaria de Estado de la Mujer. Gaceta Oficial, Santo Domingo de Guzmán, 1997. pár. III, art. 9. Disponível em: <http://goo.gl/ Xh8vDm>. 
RIO DE JANEIRO (Estado). Decreto no 43.007, de 6 de junho de 2011. Dispõe sobre reserva de vagas para negros e índios nos concursos públicos para provimento de cargos efetivos e empregos públicos integrantes dos quadros permanentes de pessoal do poder executivo e das entidades da administração indireta do estado do Rio de Janeiro. Diário Oficial do Estado, Rio de Janeiro, 6 jun. 2011.

RIO DE JANEIRO (Estado). Lei n ${ }^{\circ}$ 3.524, de 28 de dezembro de 2000. Dispõe sobre os critérios de seleção e admissão de estudantes da rede pública estadual de ensino em universidades públicas estaduais e dá outras providências. Diário Oficial do Estado, Rio de Janeiro, 2000.

RIO DE JANEIRO (Estado). Lei n ${ }^{\circ}$ 3708, de 9 de novembro de 2001. Institui cota de até $40 \%$ (quarenta por cento) para as populações negra e parda no acesso à Universidade do Estado do Rio de Janeiro e à Universidade Estadual do Norte Fluminense, e dá outras providências. Diário Oficial do Estado, Rio de Janeiro, 2001. RIO DE JANEIRO (Estado). Lei $\mathrm{n}^{\circ}$ 4.151, de 4 de setembro de 2003. Institui nova disciplina sobre o sistema de cotas para ingresso nas universidades públicas estaduais e dá outras providências. Diário Oficial do Estado, Rio de Janeiro, 2003.

SÃO PAUlO (Estado). Anais da Câmara dos Deputados de São Paulo, São Paulo, v. 1, 31 jul. 1928. $13^{a}$ Sessão Ordinária.

SÃO PAULO (Estado). Secretaria da Agricultura. Departamento de Imigração e Colonização. Boletim da Diretoria de Terras, Colonização e imigração, São Paulo, 1941.

SÃO PAULO (Estado). Regulamento para o Serviço de Imigração da Província de São Paulo. São Paulo: Tipografia do Correio Paulistano, 1887.

SÃO PAULO (Estado). Relatório apresentado à Assembleia Legislativa Provincial de São Paulo pelo presidente da Província Exmo. Sr. Dr. Francisco de Paula Rodrigues Alves. São Paulo: Tipografia a Vapor de Jorge Seckler y Comp., 10 jan. 1888.

URUGUAI. Constitución (1967). Constitución de la República Oriental del Uruguay. Montevideo, 1967. Disponível em: <https://goo.gl/YujQc9>. Acesso em: 20 jul. 2016.

VENEZUELA. Constitución (2000). Constitución de la República Bolivariana de Venezuela. In: FLANZ, G. H. 20 Constitutions of the Countries of the World, Release 2000-3. Dobbs Ferry: Oceana Publications, 2000. 
VENEZUELA. Decreto 428. Gaceta Oficial de la Republica De Venezuela, Caracas, 2005.

\section{Tratados}

CONVENÇÃO Internacional sobre a Eliminação de Todas as Formas de Discriminação Racial. 7 mar. 1966. Em vigor a partir de: 4 jan. 1969. Disponível em: $<$ http://goo.gl/yxvdlo>.

\section{Jurisprudências}

BRASIL. Supremo Tribunal Federal. ADPF 186, Petição Inicial. Brasília, DF, 20 jul. 2009. Disponível em: <http://goo.gl/N2lyA6>. Acesso em: 20 jul. 2016.

BRASIL. Supremo Tribunal Federal. ADI 3197 RJ. Relator: Min. Celso de Mello. Decisão: 19 mar. 2012. Brasília, DF, 22 mar. 2012a.

BRASIL. Supremo Tribunal Federal. RE 597285 RS. Relator: Min. Ricardo Lewandowski, 9 out. 2009, 191 DJe 1479. Brasília, DF: 19 maio 2010 b.

ESTADOS UNIDOS - U.S. District Court (D. Mass.). Ghen v. Rich, 8 F 159. Judge: Thomas Leverett Nelson. Boston, 23 abr. 1881.

ESTADOS UNIDOS. U.S. Supreme Court. Adarand Constructors, Inc. v. Peña, 515 U.S. 200, 239. Washington, DC, 1995.

ESTADOS UNIDOS. U.S. Supreme Court. Christiansburg Garment Co. v. EEOC, 434 U.S. 412, 420. Washington, DC, 1978.

INTER-AMERICAN COURT OF HUMAN RIGHTS. De Almeida v. Brazil, Case 12.440, Inter-Am. Comm’n Report No. 73/06. San José, 2006.

INTER-AMERICAN COURT OF HUMAN RIGHTS. Diniz v. Brazil, Case 12.001, Inter-Am. Comm'n Report 83/04. San José, 28 out. 2004.

INTER-AMERICAN COURT OF HUMAN RIGHTS. Mayagna (Sumo) Awas Tingni Community v. Nicaragua, 2001 Inter-Am. Ct. H.R. (serie C), n. 79. San José, 31 ago. 2001. Disponível em: <http://goo.gl/DpCUQ>. Acesso em: 20 jul. 2016. 
RIO DE JANEIRO (Estado). Tribunal de Justiça do Estado do Rio de Janeiro (11. Câmara Cível). Embargos Infringentes 2005.005.00060, CEAP v. Sony Music Entertainment Brasil, Acórdão. Rio de Janeiro, 14 dez. 2005.

RIO DE JANEIRO (Estado). Tribunal de Justiça do Estado do Rio de Janeiro. Dir. Inc. 2009.007.0009. Relator: Des. José Carlos S. Murata Ribeiro. Rio de Janeiro, 25 maio 2009a.

RIO DE JANEIRO (Estado). Tribunal de Justiça do Estado do Rio de Janeiro. Representação por Inconstitucionalidade 2009.007.00009. Relator: Des. Sérgio Cavalieri Filho. Rio de Janeiro, 18 nov. 2009b.

\section{Jornais e revistas}

15 ABOGADOS afroecuatorianos se especializan. Codae, 13 maio 2011. Disponível em: <http://goo.gl/e54RfM>.

ALAN GARCÍA pidió perdón a pueblo afroperuano en ceremonia oficial. El Comercio, Lima, 7 dez. 2009. Disponível em: <http://goo.gl/X9b0UL>.

ALVES, M. E. Negras recebem menos anestesia do que brancas. O Globo, Rio de Janeiro, 26 nov. 2006.

ALVES, J. Ouro de tolos: o estatuto da igualdade e a submissão política negra II. İrohín, Brasília, DF, 21 jun. 2010. Disponível em: <http://goo.gl/MuC1TC>.

ANDALUZ PRADO, J. A. Práctica racista y discriminatória es castigada con prisión. Diario Correo, Machala, 6 jul. 2009. Disponível em: <http://goo. $\mathrm{gl} / 7 \mathrm{mDDWm}>$.

APRODEH señala que hay más discriminación racial en Lima, Cusco y Arequipa. El Comercio, Lima, 10 mar. 2005.

ARI, M. Argentina: empanada, asado de vaca y mucho racismo. Kaos en la Red, Terrassa, 22 maio 2010. Disponível em: <http://goo.gl/H87Cjo>.

ARDITO VEGA, W. Discriminación en los servicios turísticos. La Insignia, Madrid, 5 dez. 2006. Disponível em: <http://goo.gl/OfEtss>.

AVELLANEDA, T. Manifestaciones del racismo en Cuba: varias caras de un viejo mal. Revista Consenso, La Habana, 2005. Disponível em: <http://goo.gl/0xvr7x>. 
BECAS y Maestrías. Codae, maio 2011. Disponível em: <http://goo.gl/4GUA9k>.

BENTO, M. A. S. A mulher negra no mercado de trabalho. Observatório Social, Florianópolis, n. 5 , p. 29. mar. 2004.

BRASIL. Federal Supreme Court of Brazil. STF declared the constitutionality of the quota system at the University of Brasília. STF Internacional (News Portal), Brasília, DF, 26 abr. 2012b. Disponível em: <http://goo.gl/mTYjcY>.

BRASIL. Ministério da Justiça. Supremo declara constitucionalidade do ProUni, Secretaria de Políticas de Promoção da Igualdade Racial. Portal da Secretaria de Políticas de Promoção da Igualdade Racial, Brasília, DF, 4 maio 2012c. Disponível em: <http://goo.gl/0rMLsZ>.

BRAZIL'S Unfinished Battle for Racial Democracy. The Economist, p. 31.22 abr. 2000. CEVALLOS, D. Latin America: afro-descendants marginalized and ignored. Inter Press Service News, Roma, 19 maio 2005. Disponível em: <http://goo.gl/tLDQBF>. CHENG, M. M. The face of America: new census acknowledges city's multiracial residents. Newsday, Melville, p. E6. 16 mar. 2001.

D’OU, L. El fantasma histriónico. Labor Nueva, La Habana, 27 fev. 1916.

DOUGLASS, R. E., Multiracial people must no longer be invisible. The New York Times, New York, p. A26. 12 jul. 1996.

DOWNES, P. Casi dos millones de argentinos tienen sus raíces en el Africa Negra. Clarín, Buenos Aires, 9 jun. 2006. Disponível em: <http://goo.gl/SB78wu>.

DUARTE, P. Negros são maiores vítimas do trabalho infantil no país. O Globo, Rio de Janeiro, 18 nov. 2006.

DUHARTE JIMÉNEZ, R.; GARCÍA, E. S. No hay negro bueno ni tamarindo dulce: Cuba, 118 años después de la abolición de la esclavitud. Matices, Köln, inverno 2004/2005. Disponível em: <http://goo.gl/bhGeZu>.

EL NASSER, H. Hispanic responses on race give more exact breakdown, USA Today, New York, 9 mar. 2011.

ENTIDADES criticam "racismo institucional". Correio de Sergipe, Sergipe, 20 nov. 2008. Disponível em: <http://goo.gl/ya7xP8>. 
FRIEDMAN, A. Behind the big numbers, a million little stories. The New York Times, New York, , p. 6. 18 mar. 2001. sec. 14.

GABINO, R. ¿Hay negros en Argentina? BBC Mundo, Buenos Aires, 16 mar. 2007. Disponível em: <http://goo.gl/QqQjbi>.

GALLO ROJAS, C. Igualdad sin cuotas. El Tiempo, Bogotá, p. 7. 12 jul. 2009.

GOIS, A. Brasileiros veem cota como essencial e humilhante, revela datafolha. Folha de São Paulo, São Paulo, 23 nov. 2008. Disponível em: <http://goo.gl/JaAAjZ>. Acesso em:

GOMES, W. Negros são minoria na igreja. O Globo, Rio de Janeiro, p. 3.14 maio 2007, p. 3.

IBEROAMÉRICA. ¿una región racista?, BBC Mundo, 13 out. 2005. Disponível em: $<$ http://goo.gl/15rphY>.

KASINDORF, M.; EL NASSER, H. Impact of Census' Race Data Debated. USA Today, New York, p. 1A. 13 mar. 2001.

LAMA, A. Market reforms come at a cost to education. Inter Press Service, Roma, 9 out. 1997 , p. 1.

LOPES, R. Discriminação racial pode fazer com que Brasil não cumpra Metas do Milênio. Agência Brasil, Brasília, DF, 23 nov. 2006. Disponível em: <http://goo. $\mathrm{gl} / 3 \mathrm{y} 3 \mathrm{j} T \mathrm{~s}>$.

MAROTTO, T. Brazilian secret 93 million don't want to talk about is racism. Bloomberg News, [S.1.], 26 jun. 2008. Disponível em: <http://goo.gl/iPgneG>. MATA, A. Epsy Campbell se mantendrá en el PAC. Nacion.com, San Jose, 2 jun. 2009. Disponível em: <http://goo.gl/3mKcI6>.

MENEZES, M. Vítimas de racismo perdem 57.7\% das ações. O Globo, Rio de Janeiro, 20 nov. 2008. Disponível em: <http://goo.gl/KsjIzj>.

MORGANTHAU, T. What Color Is Black? Newsweek, New York, p. 63-65. 13 fev. 1995.

NERI, C. Un grupo argentino Exterminación de los Negros de Mierda indigna en Facebook. Moebius, Buenos Aires, 2 mar. 2008. Disponível em: <http:/goo.gl/ aPBLRH>. 
OSAVA, M. Brazil: race quotas - accused of racism. Inter Press Service News, Roma, 26 jul. 2006. Disponível em: <http://goo.gl/zcUFQ5>.

PARDO, B. Member of Congress Discuss Challenges Facing Afro-Descendants in Latin America. Inter-American Dialogue, Washington, DC, 9 abr. 2008.

PASSEL, J.; WANG, W.; TAYLOR, P. Marrying out: onein-seven New U.S. marriages is interracial or interethnic. Pew Research Center Report, Washington, DC, 4 jun. 2010. Disponível em: <http://goo.gl/P5qoMN>.

PIDEN que un libro infantil que fomenta el racismo sea quitado de circulación. MDZ Online, Mendoza, 27 maio 2010. Disponível em: <http://goo.gl/NW4Dxk>.

RAVSBERG, F. Advierten sobre racismo en Cuba. BBC Mundo, London, 13 fev. 2003. Disponível em: <http://goo.gl/bCF5ED>.

RODRÍGUEZ GARAVITO, C. En defensa de las acciones afirmativas. El Espectador, Bogotá, 13 jul. 2009. Disponível em: <http://goo.gl/Xe1LP6>.

SALAZAR, H. Colomia contra el racismo. BBC Mundo, London, 23 maio 2008. Disponível em: <http://goo.gl/6lO7vD>.

SALINAS MALDONADO, C. Alta hooker rectora de la uraccan el chamán es solo la punta del iceberg. Diario de la Prensa, Managua, 22 fev. 2009. Disponível em: <http://goo.gl/dzvIjA>.

SCHMITT, E. For 7 million people in census, one race category isn't enough. The New York Times, New York, p. A1. 13 mar. 2001.

SIMS, C. Peru's blacks increasingly discontent with decorative role. The New York Times, New York, p. 2, 17 ago. 1996.

SMARTT BELL, M. A Hidden Haitian World, New York Review of Books, New York, p. 41.17 jul. 2008.

SOTO QUIRÓS, R. Desafinidad con la población nacional: discursos y políticas de inmigración en Costa Rica. Istmo, Granada, 24 jul. 2003.

STEPHENSON, K. W. Michael Campbell: el racismo está enraizado en la sociedad nicaragüense. La Brújula Digital, [S.1.], 25 fev. 2011. Disponível em: <http://goo.gl/ F35h4w>. 
VASCONCELOS, F. “Situações de discriminação só tive no Brasil”, diz Ministro do STF. Folha de São Paulo, São Paulo, 23 nov. 2008. Disponível em: <http://goo.gl/ n0K9aP>.

VEGA SFRANI, G. Universidad reserva la mitad de sus cupos para negros y desata polémica. El Mercurio, Cuenca, 22 out. 2006. Disponível em: <http://goo.gl/ NbucSi>.

VIEIRA, M. Médicos da UERJ põem à prova sistema de cotas. O Estado de S. Paulo, São Paulo, 8 maio 2011.

\section{Outras fontes primárias}

ESTADOS UNIDOS. Review of Federal Measurements of Race and Ethnicity:

Hearings before the Subcommittee on Census, Statistics and Postal Personnel of the House Committee on Post Office and Civil Service. FQ Legacy Publishing: [S.1.], 1993. (Depoimento de Carlos Fernández, presidente da Association of MultiEthnic Americans).

(A) NEGAÇÃO do Brasil: o negro na telenovela brasileira. Direção: Joel Zito Araújo. Produção: Luis Antonio Pillar, Juca Cardoso e Vandy Almeida. Montagem/ Edição: Joel Zito Araújo e Adrian Cooper. 2001. (91 min), son., color.

\section{Entrevistas}

BARBOSA, J. Entrevista com Joaquim Barbosa. [S.1.], 14 maio 2007. (Transcrição em posse de Tanya K. Hernández).

NOBLES, M. Entrevista telefônica com Melissa Nobles, profesora de Ciência Política do Massachusetts Institute of Technology. Entrevistadora: Tanya K. Hernández. [S.l.], 6 nov. 1997.

\section{Fontes secundárias}

ALBORNOZ, O. Education and society in Latin America. Pittsburgh: Macmillan, 1993. 
AMARAL, D. P.; OLIVEIRA, F. B. O ProUni e a conclusão do ensino superior: questões introdutórias sobre os egressos do programa na zona oeste do Rio de Janeiro. Ensaio: Avaliação e Políticas Públicas em Educação, Rio de Janeiro, 19 mar. 2011.

ANZOÁTEGUI, V. T. El poder de la costumbre: Estudios sobre el derecho consuetudinario en América Hispana hasta la emancipación. Buenos Aires: Instituto de Investigaciones de Historia del Derecho, 2001.

ASHER, K. Black and green: Afro-Colombians, development, and nature in the Pacific Lowlands. Durham: Duke University Press, 2009.

AZEVEDO, C. M. M. Onda negra, medo branco: o negro no imaginário das elites século XIX. São Paulo: AnnaBlume, 1987.

AZEVEDO, F. Brazilian culture: an introduction to the study of culture in Brazil. Tradução de William Rex Crawford. New York: Macmillan, 1950.

AZEVEDO, T. Democracia racial. Petrópolis: Vozes, 1975.

BANKS, R. R. Is Marriage for white people? How the African American Marriage Decline Affects Everyone. New York: Dutton, 2011.

BARBARY, O.; URREA, F. (Ed.). Gente negra en Colombia: dinâmicas sociopolíticas en Cali y el Pacífico. Medellín: Editorial Lealon, 2004

BASTIDE, R. The African religions of Brazil: toward a sociology of the interpenetration of civilizations. Tradução de Helen Sebba. Baltimore: The Johns Hopkins University Press, 1978.

BEDERMAN, D. J. Custom as a source of law. Cambridge: Cambridge University Press, 2010.

BETHELL, L. (Ed.). Latin America: politics and society since 1930. New York: Cambridge University Press, 1998.

BETWEEN the law and Their Land: Afro-Brazilian Quilombo Communities' Struggle for Land Rights. Bernard and Audre Rapoport Center for Human Rights and Justice, Austin, 22 set. 2008. Disponível em: <http://goo.gl/460bcr>.

BIERCK JUNIOR, H. A. (Ed.). Selected writings of Bolivar. volume I: 1800-1822. Tradução de Lewis Betrand. New York: Colonial Press, 1951. 
BONILLA MALDONADO, D. La Constitución multicultural. Bogotá: Siglo del Hombre, 2006.

BREWER-CARÍAS, A. R. Constitutional Protection of Human Rights in Latin America: A Comparative Study of Amparo Proceedings. Cambridge: Cambridge University Press, 2009.

BRINKS, D. M. The judicial response to police Killings in Latin America: Inequality and the Rule of Law. Cambridge: Cambridge University Press, 2008.

BRYSK, A. From Tribal Village to Global Village: Indian Rights and International Relations in Latin America. Stanford: Stanford University Press, 2000.

BUCHELI, M.; CABELA, W. Encuesta Nacional de Hogares Ampliada 2006: Perfil demográfico y socioeconómico de la población uruguaya según su ascendencia racial. Montevideo: Instituto Nacional de Estadística, 2006. p. 2. Disponível em: <http://goo.gl/54cMzS>.

BURDICK, J. Blessed Anastácia: women, race, and popular christianity in Brazil. New York: Routledge, 1998.

BURDICK, J. Legacies of liberation: the progressive catholic church in Brazil at the Start of a New Millenium. Aldershot: Ashgate, 2004.

BURKHARDT, R. W. The spirit of the system: lamarck and evolutionary biology. Cambridge, MA: Harvard University Press, 1977.

BUTLER, K. D. Freedoms given, freedoms won: Afro-Brazilians in post-abolition São Paulo and Salvador. New Brunswick: Rutgers University Press, 1998.

CALDWELL, K. L. Negras in Brazil: re-envisioning black women, citizenship, and the politics of identity. New Brunswick: Rutgers University Press, 2007.

CARDOSO, F. H.; IANNI, O. Cor e mobilidade social em Florianópolis: aspectos das relações entre negros e brancos numa comunidade do Brasil meridional. São Paulo: Companhia Editora Nacional, 1960.

CESAR, R. C. L. Ações afirmativas no Brasil: e agora, doutor? Ciência Hoje, Rio de Janeiro, v. 33, n. 195, p. 26-32, jul. 2003.

CHANOCK, M. Law, custom and social order: the colonial experience in Malawi and Zambia. Portsmouth: Heinemann, 1985. 
COLÔMBIA. Procuraduría general de la nación. El derecho a la educación: La educación en la perspectiva de los derechos humanos. Bogotá, 2006.

DAKOLIAS, M. The Judicial Sector in Latin America and the Caribbean: Elements of reform. Washington, DC: International Bank of Reconstruction and Development, 1996.

DATAFOLHA revela o brasileiro. Folha de S. Paulo, São Paulo, 25 jun. 1995, especial 2 e 3. Disponível em: <http://goo.gl/OmJIw8>. Acesso em:

DÁVILA, J. Diploma of whiteness: race and social policy in Brazil, 1917-1945.

Durham: Duke University Press, 2003.

DEAN, W. Rio Claro: a Brazilian plantation system, 1820-1920. Stanford: Stanford University Press, 1976.

DE JESÚS GALVÁN, M. Enriquillo. Santo Domingo: G. Hermanos, 1882.

DE LA BARRA, F. Invasiones militares de Lima: desde la conquista hasta la República. Austin: University of Texas Press, 2008.

DE LA TORRE, C. Afroquiteños: cidadanía y racismo. Quito: Centro Andino de Acción Popular, 2002.

DENUNCIAS por discriminación. Instituto Nacional de Defensa de la Competencia y de la Protección de la Propiedad Intelectual, Lima, [200-]. Disponível em: <http:/| goo.gl/vYnzev>.

DOMINGUES, P. Uma história não contada: negro, racismo e branqueamento em São Paulo pós-abolição. São Paulo: Paz e Terra, 2004.

DRAKE, P. W.; MCCUBBINS, M. D. The origins of liberty: political and economic liberalization in the modern world. Princeton: Princeton University Press, 1988.

ELLICKSON, R. C. Order without Law: how neighbors settle disputes. Cambridge, MA: Harvard University Press, 1991.

ELSON SIMMONS, K. Reconstructing racial identity and the African past in the Dominican Republic. Gainesville: University of Florida Press, 2009.

ESTADOS UNIDOS. Censo de Puerto Rico: 1935, Población y Agricultura. Washington, DC: U.S. Govt. print. off., 1938. 
ESTADOS UNIDOS. Department of State, Bureau of Democracy, Human

Rights, and Labor. Costa Rica, Country Reports on Human Rights Practices 2006.

Washington, DC, 6 mar. 2007. Disponível em: <http://goo.gl/nXDgMp>.

ESTADOS UNIDOS. U.S. Census Bureau. Hispanic or Latino Population by Type of Origin and Race: 2010. Washington, DC, 2010. Disponível em: <http://goo.gl/ IPR4gw>. Acesso em: 20 jul. 2016.

FEAGIN, J. R. Racist America: Roots, Current Realities and Future Reparations. New York: Routledge, 2000.

FENNEMA, M.; LOWENTHAL, T. La Construcción de raza y nación en la República Dominicana. Santo Domingo: Editora Universitaria, 1987.

FERNANDES, F. The negro in brazilian society. Tradução de Jacqueline D. Skiles, A. Brunel, Arthur Rothwell. New York: Simon \& Schuster, 1971.

FINKELMAN, P.; MILLER, J. C. (Ed.). Macmillan Encyclopedia of World Slavery. New York: Macmillan Reference, 1998.

FORUM on Poverty alleviation for minority communities: communities of African ancestry in Costa Rica, Honduras, Nicaragua, Argentina, Colombia, Ecuador, Peru, Uruguay, Venezuela. Washington, DC: Inter-American Development Bank, 1996.

FREIRE, P. Pedagogia do oprimido. Rio de Janeiro: Paz e Terra, 1987.

FREYRE, G. Casa grande e senzala. Rio de Janeiro: Maia \& Schmidt, 1933.

FREYRE, G. Sobrados e mucambos: decadencia do patriarchado rural no Brasil. São Paulo: Companhia Editora Nacional, 1936.

GALTON, F. Hereditary genius. London: Macmillan, 1869.

GARCÍA, J. C. El racismo nuestro de cada día. Aporrea, [S.1.], 21 mar. 2010.

Disponível em: <http://goo.gl/HqSo7b>.

GATES JUNIOR, H. L. Black in Latin America. New York: New York University Press, 2011.

GLYN WATKIN, T. An historical introduction to modern civil law. Aldershot: Ashgate, 1999. Law of the Nations Series.

GOLASH-BOZA, T. M. Yo Soy negro: blackness in Peru. Gainesville: University of Florida Press, 2011. 
GOLDSTEIN, D. M. Laughter out of place: race, class, violence, and sexuality in a Rio Shantytown. Berkeley: University of California Press, 2003.

GOODRICH, P. Reading the law: a critical introduction. London: Basil Blackwell, 1986.

GOTT, R. Cuba: a new history. New Haven: Yale University Press, 2005.

GOYER, D. S.; DOMSCHKE, E. The handbook of national population censuses: Spanish America and the Caribbean, North America, and Oceania. Westport: Greenwood Press, 1983.

GUIMARÃES, A. S. Preconceito e discriminação: queixas de ofensas e tratamento desigual dos negros no Brasil. Salvador: Novos Toques, 1998.

HAMMERGREN, L. A. The politics of justice and justice reform in Latin America. Boulder: Westview Press, 1998.

HELG, A. Our rightful share: the Afro-Cuban Struggle for Equality, 1886-1912. Chapel Hill: University of North Carolina, 1995.

HENTSCHKE, J. R. Reconstructing the Brazilian Nation: Public Schooling in the Vargas Era. Baden-Baden: Nomos, 2007.

HERINGER, R. Diversidade racial e relações de gênero no Brasil contemporâneo. In: CEPIA (Ed.). O progresso das mulheres no Brasil. Brasília: Unifem, 2006.

HOOKER, J. Race and the Politics of Solidarity. Oxford: Oxford University Press, 2009.

HOWARD, D. Coloring the nation: race and ethnicity in the Dominican Republic. Oxford: Signal Books, 2001.

HTUN, M. N. Dimensions of Political Inclusion and Exclusion in Brazil: Gender and Race. (Technical Papers). Washington, DC: Inter-American Development Bank, 2003.

HTUN, M. N. Dimensiones de la inclusión y exclusión política en Brasil: Género y raza. Washington, DC: Banco Interamericano de Desarrollo, 2004. Serie de informes técnicos del Departamento de Desarrollo Sostenible. Disponível em: <http://goo.gl/ abiUFn>.

IBGE. Departamento de Estatísticas de População e Sociais. Resultados da apuração de Boletim Especial l.02 da PNAD 76. Rio de Janeiro, 1976. v. 1. 
IBGE. Censo demográfico de 1991. Brasília, DF, 1991. Disponível em: <http://goo. $\mathrm{gl} / 0 \mathrm{nxUjc}>$.

IBGE. Contribuições para o estudo da demografia do Brasil. Rio de Janeiro, 1970. (Série Estudos de estatística teórica e aplicada).

INFORME 2008: presencia de afrodescendientes en los medios impresos en el año 2008. Centro de Estudios y Promoción Afroperuanos Lundu, Lima, 2008. Disponível em: <http://goo.gl/m6Y5Z7>.

INTER-AMERICAN COMMISSION ON HUMAN RIGHTS. Preliminary Observations of the Inter-American Commission on Human Rights After the Visit of the Rapporteurship on the Rights of Afro-Descendants and Against Racial Discrimination to the Republic of Colombia. Organization of American States, Washinton, DC, 27 mar. 2009.

JOLOWICZ, H. F. Historical introduction to the study of Roman law. Cambridge: Cambridge University Press, 1967.

JONES, N. A.; SMITH, A. S. The two or more races population: 2000, Census 2000 Brief. Washington, DC: U.S. Dept. of Commerce, Economics and Statistics Admin., U.S. Census Bureau, nov. 2001. Disponível em: <http://goo.gl/TQnaZm>.

JUSTICE STUDIES CENTER OF THE AMERICAS. The Judicial System and Racism against People of African Descent: The Cases of Brazil, Colombia, the Dominican Republic and Peru. [S.1.], Justice Studies Center of the Americas, mar. 2004. Disponível em: <http://goo.gl/cQsS8s>.

KAUFMANN, R.; HAGGARD, S. Development, democracy and Welfare States: Latin America, East Asia and Eastern Europe. Princeton: Princeton University Press, 2008.

KAMEL, A. Não somos racistas: uma reação aos que querem nos transformar numa nação bicolor. São Paulo: Nova Fronteira, 2006.

KOWARICK, L. Trabalho e vadiagem: a origem do trabalho livre no Brasil. São Paulo: Paz e Terra, 1987.

PERU. Defensoría del Pueblo. La discriminación en el Perú: problemática, normatividad y tareas pendientes. Lima, 2007. 
PERU. Defensoría del Pueblo. Los afrodescendientes en el Perú: una aproximación a su realidad y al ejercicio de sus derechos. Informe de Adjuntía 003-2011-DP/ADHPD, Lima, fev. 2011.

LACOMBE, A. J.; BARBOSA F. de A.; SILVA, E. Rui Barbosa e a queima dos arquivos. Rio de Janeiro: Fundação Casa de Rui Barbosa, 1988.

LARACH, L. Secondary Education Profile: a summary of secondary education: Time to Move Forward. Washington, DC: World Bank, 2001. Human Development Network Secondary Education Series Brazil. Disponível em: <http:/goo.gl/ KZoLv9>.

LEÓN, M.; HOLGUÍN, J. Acción afirmativa hacia democracias inclusivas: Colombia. Santiago: Fundación Equitas, mar. 2005, p. 208-211. Disponível em: <http://goo.gl/ oN99Ub>.

LEPARD, B. D. Customary International Law: a new theory with practical applications. Cambridge: Cambridge University Press, 2010.

LOBO, T. de S. São Paulo na federação: problemas sociais, questões raciais, política imigrantista e estudos econômicos. São Paulo: [S.n.], 1924.

LUTZ, C. H. Santiago de Guatemala, 1541-1773: city, caste, and the colonial experience. Norman: University of Oklahoma Press, 1994.

MAGGIE, Y. Medo do feitiço: relações entre magia e poder no Brasil. Rio de Janeiro: Arquivo Nacional, Orgão do Ministério da Justiça, 1992.

MARABLE, M. Malcolm X: a life of reinvention. New York: Viking, 2011.

MÁRQUEZ, G. et al. Outsiders? The changing patterns of exclusion in Latin America and the Caribbean. Washington, DC: Inter-American Development Bank, 2007.

SILVEIRA, F. A. M. Da criminalização do racismo: Aspectos jurídicos e sociocriminológicos. Belo Horizonte: Del Rey, 2006.

MARX, A. W. Making race and nation: a comparison of South Africa, The United States, and Brazil. Cambridge: Cambridge University Press, 1998.

MASTERSON, D. M.; FUNADA-CLASSEN, S. The Japanese in Latin America. Urbana: University of Illinois Press, 2004. 
MEADE, T. A. Civilizing Rio: reform and resistance in a Brazilian City, 1889-1930. University Park: Pennsylvania State University Press, 1996.

MERRYMAN, J. H.; PÉREZ-PERDOMO, R. The civil law tradition: an introduction to the legal systems of Europe and Latin America. Stanford: Stanford University Press, 2007.

MEYER-PFLUG, S. R. Liberdade de expressão e discurso do ódio. São Paulo: Editora Revista dos Tribunais, 2009.

MILLER, M. G. Rise and Fall of Cosmic Race: the Cult of Mestizaje in Spanish America. Austin: University of Texas Press, 2004.

MINTZ, S. W. Caribbean transformations. Chicago: Aldine, 1974.

MIROW, M. C. Latin American Law: a history of private law and Institutions in Spanish America. Austin: University of Texas Press, 2004.

MUSTELIER, G. E. La extinción del negro: apuntes políticos-sociales. La Habana: Imprenta y Papelería de Rambla, Bouza y Cía, 1912.

NABUCO, J. Discursos parlamentares. Brasília, DF: Câmara dos Deputados, Centro de Documentacão e Informação, Coordenacão de Publicacões, 1983.

NASCIMENTO, E. L. The sorcery of color: identity, race, and gender in Brazil. Philadelphia: Temple University Press, 2007.

PARÍS GARCÍA, I. Ideología y proceso de blanqueamiento: una aproximación construccionista a su posible influencia en la identidad y la autoimagen de tres mujeres negras venezolanas. Caracas: Fondo Editorial de Humanidades y Educación, 2002.

PASCALE, P. Actualidad afrodescendiente en Iberoamérica: estudio sobre organizaciones civiles y políticas de acción afirmativa. Madrid: Programa de las Naciones Unidaspara el Desarrollo, Secretaría General Iberoamericana, jul. 2010. Disponível em: <http://goo.gl/37uLoe>.

PÉREZ-PERDOMO, R. Latin American Lawyers: a historical introduction. Stanford: Stanford University Press, 2006.

PERSONS of African descent, discrimination and economic exclusion in Latin America. London: Minority Rights Group International, 2003. Disponível em: $<$ http://goo.gl/1Oqvo3>. 
PINHEIRO, L. et al. Retrato das desigualdades de gênero e raça. 3. ed. Brasília, DF: Instituto de Pesquisa Econômica Aplicada, 2008. Disponível em: <http://goo.gl/ ZJOn9N>. Acesso em: 20 jul. 2016.

PINTO, F. A presença do costume e sua força normativa. Rio de Janeiro: Liber Juris, 1982.

PLANK, D. N. The means of our salvation: public education in Brazil, 1930-1995. Boulder: Westview Press, 1996.

PRUDENTE, E. A. J. Preconceito racial e igualdade jurídica no Brasil. Campinas: Julex Livros, 1989.

PUEBLOS INDÍGENAS Y AFRODESCENDIENTES DE AMÉRICA LATINA Y EL CARIBE: Información sociodemográfica para políticas y programas. 2006, Santiago de Chile. Anais... Santiago de Chile: Comisión Económica para América Latina y el Caribe, 2006.

RACISMO: mais de 200 pessoas procuram o MP/BA esse ano. İrohìn, [S.l.], 19 nov. 2008. Disponível em: <http://goo.gl/9P6cv4>.

REID ANDREWS, G. The Afro-Argentines of Buenos Aires: 1800-1900. Madison: University of Wisconsin Press, 1980.

REID ANDREWS, G. Afro-Latin America: 1800-2000. New York: Oxford University Press, 2004.

REID ANDREWS, G. Blackness in the White Nation: a history of Afro-Uruguay. Chapel Hill: University of North Carolina Press, 2010.

REYNOLDS, T. H.; FLORES, A. A. Foreign law: current sources of codes and basic legislation in jurisdictions of the world, Brazil. Littleton: Fred B. Rothman \& co., 1989.

RIGHT to Education of Afro-descendant and Indigenous Communities in the Americas. Report Prepared for a Thematic Hearing before the Inter-American Commission on Human Rights. Washington, DC: Robert F. Kennedy Memorial Center for Human Rights, 2008. Disponível em: <http://goo.gl/2MID0W>. 
RODRÍGUEZ GARAVITO, C. A.; SIERRA, T. A. A.; ADARVE, I. C. El derecho a no ser discriminado: Primer informe sobre discriminación racial y derechos de la población afrocolombiana (Versión resumida). Bogotá: Universidad de los Andes, 2008.

RUTHERGLEN, G. Employment discrimination law: visions of equality in theory and doctrine. $3^{\text {nd }}$. New York: Foundation Press, 2010.

SALCEDO-BASTARDO, J. L. (Ed.). Simón Bolivar: the hope of the universe. [S.l.]: Unesco, 1983.

SÁNCHEZ, E.; GARCÍA P. Más allá de los promedios: afrodescendientes en América Latina. Washington, DC: Acnur, 2006. Disponível em: <http://goo.gl/mQT7TA>.

SÁNCHEZ, M.; BRYAN M. Afro-descendants, discrimination and economic exclusion in Latin America. London: Minority Rights Group International, maio 2003.

Disponível em: <http://goo.gl/cbt1Cd>.

SANSONE, L. Blackness without Ethnicity: Constructing Race in Brazil. New York: Palgrave Macmillan, 2003.

SANTOS, G.; DA SILVA, M. P. (Ed.). Racismo no Brasil: percepções da discriminação e do preconceito racial do século XXI. São Paulo: Fundação Perseu Abramo, 2005.

SAWYER, M. Q. Racial politics in post-revolutionary Cuba. Cambridge: Cambridge University Press, 2006.

SHELEFF, L. The future of tradition: customary law, common law and legal pluralism. London: Frank Cass, 1999.

SHERIFF, R. E. Dreaming equality: color, race and racism in urban Brazil. New Brunswick: Rutgers University Press, 2001.

SHNOOKAL, D.; MUÑIZ, M. (Ed.). José Martí Reader: writings on the Americas. Melbourne: Ocean Press, 1999.

SIEDER, R. (Ed.). Multiculturalism in Latin America: indigenous rights, diversity and democracy. Houndmills: Palgrave Macmillan, 2002.

SILVA, N. E. G. História do direito português. Lisboa: Fundacão Calouste Gulbenkian, 1991. 
SILVA JUNIOR, H. Discriminação racial nas escolas: entre a lei e as práticas socias. Brasília: Representação da Unesco no Brasil, 2002.

SKIDMORE, T. Black into white: race and nationality in Brazilian thought. New York: Oxford University Press, 1974.

SKIDMORE, T. Politics in Brazil 1930-1964: an experiment in democracy. New York: Oxford University Press, 1967.

SKINNER, D. A. Porto Rico: Report from Supervisor of the Census for the District of Porto Rico, to the Hon. E. Dana Durand, Director of the Census. Washington, DC: United States Census Bureau, 26 jul. 1910.

STEPAN, N. L. The hour of eugenics. Ithaca: Cornell University Press, 1991.

TAUNAY, C. A. Manual do agricultor brasileiro. São Paulo: Companhia das Letras, 2001.

TELLES, E. E. Race in another america: the significance of skin color in Brazil.

Princeton: Princeton University Press, 2004.

TELLES, J. H. C. Comentário crítico à Lei da Boa Razão em data de 18 de agosto de 1769. Lisboa: Typographia de Maria de Madre de Deus, 1865.

THOMAS, H. The Slave Trade: the story of the Atlantic Slave Trade, 1440-1870.

New York: Simon \& Schuster, 1997.

TRABALHOS do Congresso Agrícola do Rio de Janeiro. Rio de Janeiro: Tipografia Nacional, jun. 1878.

TWINE, F. W. Racism in a Racial Democracy: the maintenance of White Supremacy in Brazil. New Brunswick: Rutgers University Press, 1998.

USING the Inter-American System for Human Rights: a practical guide for NGOs, Global Rights Partners for Justice, [S.1.], 2004.

VAN COTT, D. L. The friendly liquidation of the past: the politics of diversity in Latin America. Pittsburgh: University of Pittsburgh Press, 2000.

VAN DIJK, T. A. Racism and discourse in Spain and Latin America. Philadelphia: John Benjamins, 2005.

VASCONCELOS, J. La raza cósmica: misión de la raza iberoamericana: notas de viajes a la América del Sur. Paris: Agencia Mundial de Librería, 1920. 
VASCONCELOS, J. The cosmic race: a Bilingual Edition, Didier T. Jaén (trans.),

2. ed. Baltimore: Johns Hopkins University Press, 1997.

VERISSIMO, L. F. O mundo é bárbaro: e o que nós temos a ver com isso. Rio de Janeiro: Objetiva, 2008.

VINOGRADOFF, S. P. Custom and right. Cambridge, MA: Harvard University Press, 1925.

WADE, P. Blackness and Race Mixture: the dynamics of racial identity in Colombia. Baltimore: Johns Hopkins University Press, 1993.

WADE, P. Race and sex in Latin America. London: Pluto Press, 2009.

WADE, P.; GIRALDO, F. U.; VIGOYA, M. V. (Ed.). Raza, etnicidad y sexualidades: ciudadanía y multiculturalismo en América Latina. Bogotá: Universidad Nacional de Colombia, 2008.

WOLFF, L.; CASTRO, C. M. Secondary education in Latin America and the Caribbean: the challenge of growth and reform. Washington, DC: Inter-American Development Bank, 2000.

\section{Artigos e capítulos de livros}

ARIZA SANTAMARÍA, R. Usos y costumbres en el procedimento administrativo: una Administración al servicio de sociedades pluriculturales. In: STEINER, C. (Ed.). Procedimiento y justicia administrativa en América Latina. Ciudad de México, DF: Fundación Konrad Adenauer, 2009.

ADORNO, S. Discriminação racial e justiça criminal em São Paulo. Novos Estudos Cebrap, São Paulo, v. 43, nov. 1995.

AGUILAR, L. E. Cuba, c. 1860-c. 1930. In: BETHELL, L. (Ed.). Cuba: a short history. Cambridge: Cambridge University Press, 1993.

ALONSO, A. M. Conforming disconformity: mestizaje, hybridity, and the aesthetics of Mexican nationalism. Cultural Anthropology, Houston, v. 19, 2004.

ÁLVAREZ, J. E. Promoting the rule of law in Latin America: problems and prospects. George Washington Journal of International Law \& Economics, Washington, DC, v. 25, 1991. 
ÁLVAREZ DE FLORES, R. Evolución histórica de las migraciones en Venezuela: Breve recuento. Aldea Mundo, San Cristóbal, v. 22, nov. 2006/abr. 2007.

AUGELLI, J. P. Cultural and Economic Changes of Bastos, a Japanese Colony on Brazil's Paulista Frontier. Annals of the Association of American Geographers, Washington, DC, v. 48, mar. 1958.

AUGUSTINE-ADAMS, K. Making Mexico: Legal Nationality, Chinese Race, and the 1930 Population Census. Law and History Review, Gainesville, v. 27, 2009.

BACELAR, J. Black in Salvador: Racial Paths. In: CROOK, L.; JOHNSON, R. (Ed.). Black Brazil: culture, identity, and social mobilization. Los Angeles: UCLA Latin American Center, 1999.

BAILY, S. L. The Adjustment of Italian Immigrants in Buenos Aires and New York, 1870-1914. American Historical Review, Bloomington, v. 88, abr. 1983.

BECK, S. H.; MIJESKI, K. J.; STARK, M. M. ¿Qué es racismo? awareness of racism and discrimination in Ecuador. Latin American Research Review, Pittsburgh, v. 46, 2011.

BENTO, M. A. S. Silent conflict: discriminatory practices and black responses in the workplace. In: REICHMANN, R. (Ed.). Race in contemporary Brazil: from indifference to inequality. University Park: Pennsylvania State University Press, 1999.

BHABHA, H. K. Of mimicry and man: the ambivalence of colonial discourse. October, Cambridge, MA, v. 28, 1984.

BIEBESHEIMER, C. Justice reform in Latin America and the Caribbean: the IDB perspective. In: DOMINGO, P.; SIEDER, R. (Ed.). Rule of Law in Latin America: the international promotion of judicial reform. London: Institute of Latin American Studies, 2001.

BLANCHARD, P. The language of liberation: slave voices in the wars of independence. Hispanic American History Review, Durham, v. 82, fev. 2002. BOLÍVAR, A. et al. Discourse and racism in Venezuela: a Café con Leche Country. In: VAN DIJK, T. A. Racism and discourse in Latin America. Lanham: Rowman \& Littlefield, 2009. 
BONILLA-SILVA, E. Are the Americas Sick with Racism or is it a problem at the poles? a reply to Christina A. Sue. Ethnic and Racial Studies, Guildford, v. 32, jul. 2009.

BONILLA-SILVA, E. We are all Americans!: the Latin Americanization of racial stratification in the USA. Race \& Society, [S.1.], v. 5, 2002.

BORAH, W. Race and class in Mexico. Pacific Historical Review, [S.l.], v. 23, 1954.

BOURDIEU, P.; WACQUANT, L. Sobre as artimanhas de razão imperialista.

Estudos Afro-Asiáticos, Rio de Janeiro, v. 1, 2002.

BRANDÃO, A.; DA MATTA, L. G. Avaliação da política de reserva de vagas na Universidade Estadual do Norte Fluminense: estudos dos alunos que ingressarem em 2003. In: BRANDÃO, A. A. (Ed.). Cotas raciais no Brasil: a primeira avaliação. Rio de Janeiro: DP\&A, 2007.

BROWN, D. de G. Power, Invention, and the Politics of Race: Umbanda Past and Future. In: CROOK, L.; JOHNSON, R. (Ed.). Black Brazil: culture, identity, and social mobilization. Los Angeles: UCLA Latin American Institute, 1999.

CALDWELL, K. L. Look at Her Hair: The Body Politics of Black Womanhood in Brazil. Transforming Anthropology, Arlington, v. 11, 2004.

CARVALHO, J. A. M. de. et al. Estimating the stability of census-based racial/ethnic classifications: the case of Brazil. Population Studies, Hudson, v. 58, 2004.

CARVALHO, J. J. de. As propostas de cotas para negros e o racismo acadêmico no Brasil, Sociedade e Cultura, Goiânia, v. 4, jul./dez. 2001.

CASAL, L. Race Relations in Contemporary Cuba. In: DZIDZIENYO, A.; CASAL, L. (Ed.). The Position of Blacks in Brazilian and Cuban Society. London: Minority Rights Group, 1979.

CASTELLANOS GUERRERO, A. et al. Racist Discourse in Mexico. In: VAN DIJK, T. A. (Ed.). Racism and discourse in Latin America. Lanham: Lexington Books, 2009.

CASTELLUCCI, I. Law v. Statute, Ius v. Lex: An Analysis of a Critical Relation in Roman and Civil Law. Global Jurist, [S.l.], v. 8, 2008. 
CAULFIELD, S. Interracial Courtship in the Rio de Janeiro Courts, 1918-1940. In: APPLEBAUM, N. P.; MACPHERSON, A. S.; ROSENBLATT, K. A. (Ed.). Race and Nation in Modern Latin America. Chapel Hill: University of North Carolina Press, 2003.

CHALHOUB, S. Medo branco de almas negras: escravos, libertos e republicanos na cidade do Rio. Revista Brasileira de Historia, Salvador, v. 8, 1988.

CHANOCK, M. Law, State and Culture: Thinking about "Customary Law” after Apartheid. Acta Juridica, Claremont, 1991.

CHANOCK, M. Neither customary nor legal: African customary law in an era of family law reform. International Journal of Law and the Family, Cary, v. 3, 1989.

CHEN, J. Unloving. Iowa Law Review, Iowa City, v. 80, 1994.

CHO, S. Post-racialism. Iowa Law Review, Iowa City, v. 94, 2009.

CONVENIO de Cooperación Interinstitucional entre la Corporación de Desarrollo Afroecuatoriano - CODAE y el Ilustre Municipio del Cantón Ibarra. Quito:

CODAE, Ilustre Municipio del Cantón Ibarra, 2010. Disponível em: <http://goo.gl/ nu1a8H>.

COOK, R. J. Overcoming discrimination: introduction. In: MÉNDEZ, J. E.; O'DONNELL, G.; PINHEIRO, P. S. (Ed.). The (Un)rule of law and the underprivileged in Latin America. Notre Dame: University of Notre Dame Press, 1999.

CORREA, E. Indios, mestizos, negros y blancos en un município de la Costa Chica, Oaxaca a través de un censo de 1890. Suplemento del Boletín Diario de Campo, Ciudad de México, mar./abr. 2007.

CORREA, E. Cotas no Brasil: um panorama da aplicação de políticas afirmativas nas universidades públicas. Revista Adusp, São Paulo, v. 43, jul. 2008.

COURTIS, C. et al. Racism and discourse: a portrait of the Argentine situation. In: VAN DIJK, T. A. (Ed.). Racism and Discourse in Latin America. Lanham: Lexington Books, 2009. 
CUNHA, O. M. G. da. The stigmas of dishonor: criminal records, civil rights, and forensic identification in Rio de Janeiro, 1903-1940. In: CAULFIELD, S.; CHAMBERS, S. C. (Ed.). Honor, Status, and Law in Modern Latin America. Durham: Duke University Press, 2005.

DARITY JUNIOR, W. et al. Bleach in the rainbow: latin ethnicity and preference for whiteness. Transforming Anthropology, New York, v. 13, out. 2005.

DE LA FUENTE, A. Race and inequality in Cuba, 1899-1981. Journal of Contemporary History, Cambridge, Austin, v. 30, 1995.

DE LA TORRE, C. Afro-Ecuadorian responses to racism: between citizenship and corporatism. In: DZIDZIENYO, A.; OBOLER, S. (Ed.). Neither Enemies nor Friends: Latinos, Blacks, Afro-Latinos. New York: Macmillan, 2005.

DIXON, K. Transnational Black Social Justice Movements in Latin America: afroColombians and the Struggle for Human Rights. In: STAHLER-SHOLK, R.; VANDEN, H. E.; KUECKER, G. D. (Ed.). Latin American Social Justice Movements in the Twenty-First Century: Resistance, Power, and Democracy. Lanham: Rowman \& Littlefield, 2008.

DULITZKY, A. E. A region in denial: racial discrimination and racism in Latin America. In: DZIDZIENYO, A.; OBOLER, S. (Ed.). Neither Enemies nor Friends: Latinos, Blacks, Afro-Latinos. New York: Palgrave MacMillan, 2005.

DZIDZIENYO, A. The Changing World of Brazilian Race Relations? In:

DZIDZIENYO, A.; OBOLER, S. (Ed.). Neither Enemies nor Friends: Latinos, Blacks, Afro-Latinos. New York: Palgrave MacMillan, 2005.

ENGERMAN, S. L.; SOKOLOFF, K. L. The Evolution of Suffrage Institutions in the New World. Journal of Economic History, Boulder, v. 65, dez. 2005.

EURAQUE, D. A. The Banana Enclave, Nationalism and Mestizaje in Honduras, 1910s-1930s. In: CHOMSKY, A.; LAURIA, A. (Ed.). At the Margins of the NationState: Identity and Struggle in the Making of the Laboring Peoples of Central America and the Hispanic Caribbean, 1860-1960. Durham: Duke University Press, 1998.

ESQUIROL, J. L. The Failed Law of Latin America. American Journal of Comparative Law, Ann Arbor, v. 56, Winter 2008. 
FARAH SCHWARTZMAN, L. Does Money Whiten? Intergenerational Changes in Racial Classification in Brazil. American Sociological Review, Washington, DC, v. 72 , dez. 2007.

FELICIANO, C.; ROBNETT, B.; KOMAIE, G. Gendered Racial Exclusion among White Internet Daters. Social Science Research, Charlotte, v. 38, mar. 2009.

FERREIRA, R. F. O brasileiro, o racismo silencioso e a emancipação do afrodescendante. Psicologia \& Sociedade, Belo Horizonte, v. 14, jan./jun. 2002. FERNÁNDEZ, R. America beyond Black and White: how immigrants and fusions are helping to overcome the racial divide. Ann Arbor: University of Michigan Press, 2007.

FIGUEIREDO, A. Out of place: the experience of the Black Middle Class. In: REITER, B.; MITCHELL, G. L. (Ed.). Brazil's new racial politics. Boulder: Lynne Rienner, 2010.

FITZPATRICK, P. Traditionalism and traditional law. Journal of African Law, London, v. 28, 1984.

FOOTE, N. Race, State and Nation in Early Twentieth Century Ecuador. Nations and Nationalism, Malden, v. 12, 2006.

FRANK, R.; AKRESH, I. R.; LU, B. Latino Immigrants and the U.S. Racial Order: How and Where Do They Fit In? American Sociological Review, Washington, DC, v. 75, jun. 2010.

FRY, P.; CARRARA, S; MARTINS-COSTA, A. L. Negros e brancos no carnaval da velha república. In: REIS, J. J. (Ed.). Escravidão e a invencão da liberdade: Estudos sobre o Negro no Brasil. São Paulo: Brasiliense, Brasília, DF: CNPq, 1988.

GARRO, A. M. Access to Justice for the Poor in Latin America. In: MÉNDEZ, J. E.; O'DONNELL, G.; PINHEIRO, P. S. (Ed.). The (Un)Rule of Law and the Underprivileged in Latin America. Notre Dame: University of Notre Dame Press, 1999.

GARNER, B. A. (Ed.). Black's Law Dictionary. 8 $^{\text {th }}$. St. Paul: Thomson/West, 2005.

GASTWIRTH, J. L. Issues Arising in the Use of Statistical Evidence in Discrimination Cases. In: GASTWIRTH, J. L. (Ed.). Statistical Science in the Courtroom. New York: Springer, 2000. 
GENTILI, P. Educación y ciudadanía: un desafío para América Latina. In: ASSAEL, J. et al. (Ed.). Reforma educativa y objetivos fundamentales transversales. Santiago: Programa Interdisciplinario de Investigaciones en Educación, 2003.

GILANSHAH, B. Multiracial Minorities: Erasing the Color Line. Law \& Inequality Journal, Minneapolis, v. 12, 1993.

GLOBAL RIGHTS PARTNERS FOR JUSTICE. Using the Inter-American System for Human Rights: A Practical Guide for ngos, 2004, p. 14-15. Disponível em: $<$ http://bit.ly/2b3FCNi>.

GODREAU, I.; LLORÉNS, H.; VARGAS-RAMOS, C. Employing Incongruence at Work: Employing U.S. Census Racial Categories in Puerto Rico. Anthropology News, Arlington, maio 2010.

GOMES, J. B. O debate constitucional sobre as ações afirmativas. In:

GUIMARÃES, A. S. A. et al. (Ed.). Ações afirmativas: políticas públicas contra as desigualdades raciais. Rio de Janeiro: DP\&A, 2003.

GONZÁLEZ NAVARRO, M. Mestizaje in Mexico during the National Period. In: MÖRNER, M. (Ed.). Race and Class in Spanish America. New York: Columbia University Press, 1970.

GOTT, R. Spanish America as a White Settler Society. Bulletin of Spanish American Research, Malden, v. 26, 2007.

GROSSMAN, C. The Inter-American system of human rights: challenges for the future. Indiana Law Journal, Bloomington, v. 83, 2008.

GUEVARA, G. R. Inexacting Whiteness: Blanqueamiento as a Gender-Specific Trope in the Nineteenth Century. Cuban Studies Journal, Pittsburgh, v. 36, 2005. GUIMARÃES, A. S. A. Ações afirmativas para a população negras nas universidades brasileiras. In: SANTOS, R. E. dos.; LOBATO, F. (Ed.). Ações Afirmativas: politicas publicas contra as desigualdades racias. Rio de Janeiro: Programa Políticas da Cor na Educação Brasileira, 2003.

GUZMÁN BRITO, A. El régimen de la costumbre en las codificaciones civiles de Hispanoamérica y España empreendidas durante el siglo XIX. Revista de Estudos Histórico-Jurídicos, Valparaíso, n. 12, 1987. Disponível em: <http://goo.gl/RKJZCH>. 
HADDAD, E. G. O costume como parâmetro da aplicação da justiça e da criação da lei. Jus Navigandi, Teresina, v. 11, n. 1315, 6 fev. 2007.

HARPELLE, R. N. Ethnicity, religion and repression: the denial of African Heritage in Costa Rica. Canadian Journal of History, Saskatoon, v. 29, abr. 1994.

HARPELLE, R. N. The social and political integration of West Indians in Costa Rica: 1930-50, Journal of Latin American Studies, New York, v. 25, fev. 1993.

HELG, A. Race and black mobilization in colonial and early independent Cuba: a comparative perspective. Ethnography, Durham, v. 44, 1997.

HELG, A. Race in Argentina and Cuba, 1880-1930: theory, policies, and popular reaction. In: GRAHAM, R. (Ed.). The Idea of Race in Spanish America, 1870-1940. Austin: University of Texas Press, 1990.

HEREDIA, C.; GIRALDO, F. U.; LÓPEZ, C. A. V. Un breve acercamiento a las políticas de Acción Afirmativa: orígenes, aplicación y experiencia para grupos étnico-raciales en Colombia y Cali. Revista Sociedad y Economia, Cali, v. 169, jan. 2009. Disponível em: <http://goo.gl/jG2XqL>.

HERINGER, R. Ação afirmativa e promoção da igualdade racial no Brasil: o desafio da prática. In: PAIVA, A. R. (Ed.). Ação afirmativa na universidade: reflexão sobre experiências concretas Brasil-Estados Unidos. Rio de Janeiro: Editora PUC-Rio, 2004.

HOETINK, H. The Dominican Republic in the Nineteenth Century: some notes on stratification, immigration, and race. In: MÖRNER, M. (Ed.). Race and Class in Spanish America. New York: Columbia University Press, 1970.

HOLLOWAY, T. P. Immigration and Abolition: The Transition from Slave to Free Labor in the São Paulo Coffee Zone. In: ALDEN, D.; DEAN, W. (Ed.). Essays concerning the socioeconomic history of Brazil and portuguese India. Gainesville: University Press of Florida, 1977.

HOOKER, J. Afro-descendant struggles for collective rights in Latin America: Between Race and Culture. Souls, Chicago, v. 10, 2008.

HTUN, M. N. From "Racial Democracy" to affirmative action: changing state policy on race in Brazil. Latin American Research Review, Pittsburgh, v. 39, fev. 2004. 
HTUN, M. N.; JONES, M. Engendering the right to participate in decisionmaking: electoral quotas and women's leadership in Latin America. In: CRASKE, N.; MOLYNEUX, M. (Ed.). Gender and the Politics of Rights and Democracy in Latin America. London: Palgrave MacMillan, 2002.

ISFAHANI-HAMMOND, A. Introduction: Who Were the Masters in the Americas? In: ISFAHANI-HAMMOND, A. (Ed.). The Masters and the Slaves: plantation relations and mestizaje in American Imaginaries. New York: Palgrave MacMillan 2004.

JIMÉNEZ CASTRO, M. Las máscaras del chiste racista. InterSedes: Revista de las Sedes Regionales, Liberia Guancaste, v. 2, 2001.

JOHNSON JUNIOR, A. M. Destabilizing racial classifications based on insights gleaned from trademark law. California Law Review, Berkeley, v. 84, 1996.

JOHNSON, P. C. Law, Religion, and public health in the Republic of Brazil. Law and Social Inquiry, Chicago, v. 26, 2001.

JOHNSON, Z. C. Overview of Vestibular: the Brazilian College Entrance Exams. International Human Rights Law Group, [S.1.], maio 2003.

KILSZTAJN, S. et al. Concentração e distribuição do rendimento por raça no Brasil. Revista de Economia Contemporânea, Rio de Janeiro, v. 9, n. 2, maio/ago. 2005.

KING, J. F. The Case of José Ponciano de Ayarza: A Document on Gracias al Sacar. Hispanic American History Review, Durham, v. 31, 1951.

KLEIN, H. S. The Integration of Italian Immigrants into the United States and Argentina: A Comparative Analysis. American Historical Review, Bloomington, v. 88, abr. 1983.

LEE, J.; BEAN, F. D. Reinventing the color line: immigration and America's New Racial/Ethnic Divide. Social Forces, Chapel Hill, v. 86, dez. 2007.

LEHMANN, D. Gilberto Freyre: The Reassessment Continues. Latin American Research Review, Pittsburgh, v. 43, 2008.

LESSER, J. Immigration and Shifting Concepts of National Identity in Brazil during the Vargas Era. Luso-Brazilian Review, Madison, v. 31, 1994. 
LIMA, R. S.; TEIXEIRA, A.; SIGNORETTO, J. Mulheres negras: as mais punidas nos crimes de roubo. Boletim do Núcleo de Pesquisas IBCCRIM, São Paulo, v. 125, abr. 2003.

LITVINOFF, S. Moral Damages. Louisiana Law Review, Baton Rouge, v. 38, 1977.

LOVELL, P. A. Gender, Race, and the Struggle for Social Justice in Brazil. Latin American Perspectives, Riverside, v. 27, nov. 2000.

LOVELL, P. A. Race, Gender, and Work in São Paulo, Brazil, 1960-2000. Latin American Research Review, Pittsburgh, v. 41, out. 2006.

LOVELL, P. A. Women and Racial Inequality at Work in Brazil. In: HANCHAR, M. (Ed.). Racial politics in contemporary Brazil. Durham: Duke University Press, 1999.

LOVELL BANKS, T. Mestizaje and the Mexican Mestizo Self: no hay sangre negra, so there is no blackness. Southern California Interdisciplinary Law Journal, Los Angeles, n. 15, 2006.

LOVEMAN, M.; MUÑIZ, J. O. How Puerto Rico became white: boundary dymanics and intercensus racial reclassification. American Sociological Review, Washington, DC, n. 72, dez. 2007.

LOWRIE, S. H. O elemento negro na população de São Paulo. Revista do Arquivo Municipal, São Paulo, n. 48, jun. 1938.

LOWRIE, S. H. The negro element in the population of São Paulo, a Southernly State of Brazil. Phylon, Atlanta, v. 3, 1942.

LOWRIE, S. H. Racial and National Intermarriage in a Brazilian City. American Journal of Sociology, Chicago, v. 44, mar. 1939.

LUIZ, M. S. A mulher negra no mercado de trabalho: a pseudoequidade, marcada pela discriminação da sociedade e a mídia no século. Partes, São Paulo, 9 set. 2010. Disponível em: <http://goo.gl/nzGyze>.

MAHONY, M. A. Afro-Brazilians, land reform, and the question of social mobility in southern Bahia, 1880-1920. In: KRAAY, H. (Ed.). Afro-Brazilian Culture and Politics: Bahia, 1790's to 1990's. Armonk: M.E. Sharpe, 1998.

MAKABE, T. Ethnic Hegemony: The Japanese Brazilians in Agriculture, 1908-1968. Ethnic and Racial Studies, Guildford, v. 22, jul. 1999. 
MARAM, S. L. Labor and the Left in Brazil, 1890-1921: A Movement Aborted. Hispanic American Historical Review, Durham, v. 57, 1977.

MARAM, S. L. Urban labor and social change in the 1920's. Luso-Brazilian Review, Madison, v. 16, 1979.

MASON MANDIVER, M. Racial classifications in Spanish American Censuses. Social Forces, Chapel Hill, v. 28, dez. 1949.

MARTÍNEZ, F. Apogeo y decadencia del ideal de la inmigración europea en Colombia, siglo XIX, Boletín Cultural y Bibliográfico, Bogotá, v. 34, 1998.

MARTÍNEZ-ECHAZÁBAL, L. Mestizaje and the discourse of national/cultural identity in Spanish America, 1845-1959. Latin American Perspectives, Riverside, v. 25, maio 1998.

MARTÍNEZ MIRANDA, L. G. Desde adentro: una aproximación al tema de Verdad, Justicia y Reparación a partir de las víctimas afrocolombianas. In: ROSEROLABBÉ, C. M.; BARCELOS, L. C. (Ed.). Afro-reparaciones: memorias de la esclavitud y justicia reparativa para negros, afrocolombianos y raizales. Bogotá: Universidad Nacional de Colombia, 2006.

MARTINS, F. Racism in Brazilian aquarelle: the place of denying. International Journal of Migration, Health and Social Care, [S.1.], v. 4, out. 2008.

MASFERRER, M.; MESA-LAGO, C. The Gradual Integration of the Black in Cuba: Under the Colony, the Republic, and the Revolution. In: TOPLIN, R. B. (Ed.). Slavery and race Relations in Spanish America. Westport: Greenwood Press, 1974.

MATOY CARLSON, K. Notice: premature predictions of multiculturalism? Michigan Law Review, Ann Arbor, v. 100, maio 2002.

MITCHELL, M. J.; WOOD, C. H. Ironies of citizenship: skin color, police brutality, and the challenge to democracy in Brazil. Social Forces, Chapel Hill, v. 77, mar. 1999. MORAES DA SILVA, G.; REIS, E. P. Perceptions of racial discrimination among black professionals in Rio de Janeiro. Latin American Research Review, Pittsburgh, v. 46, 2011.

MURPHY, J. B. Habit and convention at the foundation of custom. In: PERREAUSAUSSINE, A.; MURPHY, J. B. (Ed.). The nature of customary law: legal, historical and philosophical perspectives. Cambridge: Cambridge University Press, 2007. 
MUTEBA RAHIER, J. Blackness and the racial spatial order, migration, and miss Ecuador 1995-1996. American Anthropologist, Arlington, v. 100, 1998.

MUTEBA RAHIER, J. Soccer and the (Tri-)color of the ecuadorian nation: visual and ideological (dis)continuities of black otherness from monocultural mestizaje to multiculturalism. Visual Anthropology Review, Arlington, v. 24, 2008.

NASCIMENTO, A.; NASCIMENTO, E. L. Dance of Deception: reading of race relations in Brazil. In: HAMILTON, C. V. et al. (Ed.). Beyond racism: race and inequality in Brazil, South Africa, and the United States. Boulder: Lynne Rienner, 2001.

NASCIMENTO, Á. P. Um reduto negro: cor e cidadania na Armada (18701910). In: CUNHA, O. M. G.; GOMES, F. dos S. (Ed.). Quase-cidadão: histórias e antropologias da pós-emancipação no Brasil. Rio de Janeiro: FGV Editora, 2007. NASCIMENTO, E. L. Aspects of Afro-Brazilian Experience. Journal of Black Studies, Philadelphia, v. 11, 1980.

NASCIMENTO, E. L. It's in the Blood: notes on race attitudes in Brazil from a different perspective. In: HAMILTON, C. V. et al. (Ed.). Beyond Racism: Race and Inequality in Brazil, South Africa, and the United States, Boulder: Lynne Rienner, 2001.

NAVA, C. Lessons in patriotism and good citizenship: national identity and nationalism in public schools during the Vargas Administration, 1937-1945. LusoBrazilian Review, Madison, v. 35, verão 1998.

NIELSEN, L. B.; NELSON, R. L.; LANCASTER, R. Individual justice or collective legal mobilization? Employment discrimination litigation in the post civil rights United States. Journal of Empirical Legal Studies, Malden v. 7, jun. 2010.

NOBLES, M. Shades of citizenship: race and the census in modern politics. Stanford: Stanford University Press, 2000.

OBOLER, S. The foreignness of racism: pride and prejudice among Peru's Limenos in the 1990s. In: DZIDZIENYO, A.; OBOLER, S. (Ed.). Neither enemies nor friends: latinos, blacks, Afro-Latinos. New York: Palgrave MacMillan, 2005.

PAIXÃO, M. et al. M. Relatório anual das desigualdades raciais no Brasil, 2009-2010. Rio de Janeiro: Garamond, 2010. 
PEDROSA, R. H. L. et al. Academic performance, students' background and affirmative action at a Brazilian University, Higher Education Management and Policy, Paris, v. 19, 2007.

PEÑA, Y.; SIDANIUS, J.; SAWYER, M. Racial democracy in the Americas: a Latin and U.S. Comparison, Journal of Cross-Cultural Psychology, [S.l.], v. 35, nov. 2004.

PÉREZ JUNIOR, L. A. Politics, peasants, and people of color: the 1912 Race War in Cuba Reconsidered. Hispanic American History Review, Durham, v. 66, 1986.

PERREAU-SAUSSINE, A.; MURPHY, J. B. The Character of Customary Law: An Introduction. In: PERREAU-SAUSSINE, A.; MURPHY, J. B. (Ed.). The nature of customary law: legal, historical and philosophical perspectives. Cambridge: Cambridge University Press, 2007.

PETERSEN, H. Reclaiming juridical tact? observations and reflections on customs and Informal Law as (pluralist) sources of polycentric law. In: PETERSEN, H.; ZAHLE, H. (Ed.). Legal Polycentricity: Consequences of Pluralism in Law. Aldershot: Dartmouth, 1995.

PINHEIRO, P. S. The rule of law and the underprivileged in Latin America: introduction. In: MÉNDEZ, J. E.; O’DONNELL, G.; PINHEIRO, P. S. (Ed.). The (Un)rule of law and the underprivileged in Latin America. Notre Dame: University of Notre Dame Press, 1999.

PITANGA, A.; CROOK, L.; JOHNSON, R. Where Are the Blacks? In: CROOK, L.; JOHNSON, R. (Ed.). Black Brazil: Culture, Identity, and Social Mobilization. Los Angeles: UCLA Latin American Center, 1999.

PLAN PLURINACIONAL para eliminar la discriminación racial y la exclusión étnica y cultural. Quito: Programa Desarrollo y Diversidad Cultural, Unesco, 2009. Disponível em: <http://goo.gl/PpoRLP>.

POSSO, J. Mecanismos de discriminación étnico-racial, classe social y género: la inserción laboral de mujeres negras en el servicio doméstico de Cali. In: ARGÜELLES, M. del C. Z. (Ed.). Pobreza, exclusión social y discriminación étnicoracial en América Latina y el Caribe. Bogotá: Siglo del Hombre Editores y Clacso, 2008.

QUEIROZ, D. M.; SANTOS, J. T. Sistema de cotas: um debate: dos dados à manutenção de privilégios e de poder. Educação e Sociedade, Campinas, v. 27, 2006. 
RACUSEN, S. Fictions of Identity and Brazilian Affirmative Action. National Black Law Journal, Los Angeles, v. 21, 2009.

RACUSEN, S. Making the impossible determination: flexible identity and targeted opportunity in contemporary Brazil. Connecticut Law Review, Hartford, v. 36, 2004.

RAMA, C. M. The passing of the Afro-Uruguayans from caste society into class society. In: MÖRNER, M. (Ed.). Race and class in Spanish America. New York: Columbia University Press, 1970.

REID ANDREWS, G. Black and white workers: São Paulo, Brazil, 1888-1928. Hispanic American Historical Review, Durham, v. 68, ago. 1988.

REID ANDREWS, G. Brazilian Racial Democracy, 1900-90: an american counterpoint. Journal of Contemporary History, Cambridge, v. 31, 1996.

REITER, B. Inequality and School Reform in Bahia, Brazil. International Review of Education, [S.1.] v. 55, 2009.

ROSA, A. J. El Que No Tiene Dingo, Tiene Mandingo: the inadequacy of the 'mestizo as a theoretical construct in the field of spanish american studies - the Problem and Solution. Journal of Black Studies, Philadelphia, v. 27, 1996.

ROSENBLAT, A. La población indígena y el mestizaje en América. v. II. Buenos Aires: Editorial Nova, 1954.

ROSERO, C. Los afrodescendientes y el conflicto armado em Colombia: la insistencia en lo propio como alternativa. In: MOSQUERA, C.; PARDO, M.; HOFFMAN, O. (Ed.). Afrodescendientes en las Américas: trayectorias sociales e identitarias, 150 años de la abolición de la esclavitud en Colombia. Bogotá: Universidad Nacional de Colombia, 2002.

ROSSATO, C.; GESSER, V.; CAVALLEIRO, E. (Ed.). A experiencia da branquitude diante de conflitos racias: Estudos de realidades brasileiras e estadunidenses. In: CAVALLEIRO, E. (Org.). Racismo e antirracismo na educação: repensando nossa escola. São Paulo: Selo Negro, 2001.

SACO, J. A. Colección de papeles científicos, históricos y políticos sobre la isla de Cuba, v. 3. Paris: Impr. De d'Aubusson y Kugelmann, 1858. 
SAFA, H. I. Racial and Gender Inequality in Latin America: Afro-descendant Women Respond. Feminist Africa Diaspora Voices, Cape Town, 2007. Disponível em: <http://goo.gl/qTTf7l>.

SAFFORD, F. Race, Integration, and Progress: Elite Attitudes and the Indian in Colombia, 1750-1870. Hispanic American Historical Review, Durham, v. 71, 1991.

SANJEK, R. Brazilian Racial Terms: Some Aspects of Meaning and Learning. American Anthropologist, Arlington, v. 73, out. 1971.

SANTOS, S. A. dos. Who Is Black in Brazil? A Timely or a False Question in Brazilian Race Relations in the Era of Affirmative Action? Latin American Perspectives, Riverside, v. 33, jul. 2006.

SANTOS, S. A.; HALLEWELL, L. Historical Roots of the Whitening of Brazil. Latin American Perspectives, Riverside, v. 29, jan. 2002.

SAUNDERS, M. L. Of minority representation, multiple-race responses, and Melting Pots: Redistricting in the New America. North Carolina Law Review, Chapel Hill, v. 79, 2001.

SAUTU, R. Poverty, psychology, and dropouts. In: RANDALL, L.; ANDERSON, J. B. (Eds.). Schooling for success: preventing repetition and dropout in Latin American Primary Schools. Armonk: M. E. Sharpe, 1999.

SAVASTANO, G. Custom as a Source of Law: Argentinean and Comparative Legal Systems. ILSA Journal of International and Comparative Law, Washington, DC, v. 15, 2009.

SIEDER, R. Conclusions: Promoting the Rule of Law in Latin America. In: DOMINGO, P.; SIEDER, R. (Eds.). Rule of Law in Latin America: The International Promotion of Judicial Reform. London: Brookings Institution Press, 2001.

SILVA, E. G.; SFOGGIA, I. O crime de racismo na legislação penal brasileira: Passado, presente e futuro. Igualdade, [S.1.], v. 5, jan./mar. 1997.

SILVA, N. do V. Morenidade: modo de usar. Estudos Afro-Asiáticos, Rio de Janeiro, v. $30,1996$.

SILVA, N. do V.; HASENBALG, C. A. Race and educational opportunity in Brazil. In: REICHMANN, R. (Ed.). Race in contemporary Brazil: from indifference to inequality. University Park: Penn State University Press, 1999. 
SILVA, N. do V.; HASENBALG, C. A. Estrutura social, mobilidade e raça. São Paulo: Vértice, 1988.

SKIDMORE, T. E. Racial ideas and social policy in Brazil, 1870-1940. In:

GRAHAM, R. (Ed.). The idea of race in Latin America, 1870-1940. Austin: University of Texas Press, 1990.

SMITH, D. H. Civil Rights: A problem in communication. Phylon, Atlanta, v. 27, 1966.

SUE, C. An assessment of the latin americanization thesis. Ethnic and Racial Studies, Guildford, v. 6, 2009.

SUTIL, J. C. Judicial reforms in Latin America: good news for the Underprivileged? In: MÉNDEZ, J. E.; O’DONNELL, G.; PINHEIRO, P. S. (Ed.). The (Un)rule of law and the underprivileged in Latin America. Notre Dame: University of Notre Dame Press, 1999.

TELLES, E. Residential Segregation by Skin Color in Brazil. American Sociological Review, Washington, DC, v. 57, 1992.

TELLES, E. Racial Ambiguity among the Brazilian Population. Ethnic and Racial Studies, Guildford, v. 25, maio 2002.

THE BERNARD AND AUDRE CENTER FOR HUMAN RIGHTS AND JUSTICE. A Report on the Development of Ley 70 of 1993: Submitted to the InterAmerican Commission on Human Rights. Austin, 2007. Disponível em: <http://goo. $\mathrm{gl} / \mathrm{xkML} 2 \mathrm{l}>$.

TORRES, A. La gran familia puertorriqueña Ej Preita de Beldá. In: TORRES, A.; WHITTEN JUNIOR, N. E. (Ed.). Blackness in Spanish America and the Caribbean, v. 2. Bloomington: Indiana University Press, 1998.

TREVIÑO GONZÁLEZ, M. Opportunities and Challenges for the Afro-Brazilian Movement. In: REITER, B.; MITCHELL, G. L. (Ed.). Brazil's New Racial Politics. Boulder: Lynne Rienner, 2010.

TROCHIM, M. R. The Brazilian Black Guard. Americas, [S.l.], v. 44, jan. 1988.

VALERY WHITE, J. The Activist Insecurity and the Demise of Civil Rights Law. Louisiana Law Review, Baton Rouge, v. 63, 2003. 
VARGAS, J. A. Moral Damages under the Civil Law of Mexico: are these damages equivalent to U.S. Punitive Damages? Inter-American Law Review, Coral Gables, v. 35, 2004.

VARGAS, J. H. C. When a favela dared to become a gated community: the politics of race and urban space in Rio de Janeiro. Latin American Perspectives, Riverside, v. 33, jul. 2006.

VÁSQUEZ, M. C. Immigration and mestizaje in nineteenth-century Peru. In: MÖRNER, M. (Ed.). Race and class in Spanish America. New York: Columbia University Press, 1970.

VAUGHN, B. Afro-Mexico: Blacks, Indígenas, Politics, and the Great Diaspora. In: DZIDZIENYO, A.; OBOLER, S. (Ed.). Neither Enemies nor Friends: Latinos, Blacks, Afro-Latinos. Houndmills: Palgrave MacMillian, 2005.

VELLOSO, J. Curso e concurso: rendimento no universidade e desempenho en um vestibular com cotas da UnB. Cadernos de Pesquisa, São Paulo, v. 39, 2009.

WADE, P. Afro-Latin studies: reflections on the Field. Latin American and Caribbean Ethnic Studies, [S.1.], v. 1, abr. 2006.

WATSON, A. An approach to customary law. University of Illinois Law Review, Champaign, v. 1984, n. 3, 1984.

WEINSTEIN, B. Racializing regional difference: São Paulo versus Brazil, 1932. In: APPLEBAUM, N. P.; MACPHERSON, A. S.; ROSENBLATT, K. A. (Ed.). Race and Nation in Modern Latin America. Chapel Hill: University of North Carolina Press, 2003.

WERNECK, J. The beautiful and the pure? racism, eugenics and new (bio) technologies. In: ROTANIA, A.; WERNECK, J. (Ed.). Under the sign of biopolitics: critical voices from civil society reflections in Brazil, vol. I. Rio de Janeiro: e-papers, 2004.

WHITTEN JUNIOR, N. El Mestizaje: an all inclusive ideology of exclusion. In: WHITTEN JUNIOR, N. (Ed.). Cultural Transformation and Ethnicity in Modern Ecuador. Urbana: University of Illinois Press, 1981.

WILLIAMS CRENSHAW, K. Twenty years of critical race theory: looking backward to move forward. Connecticut Law Review, Hartford, v. 43, 2011. 
WILLIAMS, P. J. Spare parts, family values, old children, cheap. New England Law Review, Boston, v. 28, 1994.

WOLFF, L.; CASTRO, C. M. Secondary education in Latin America and the Caribbean: the challenge of growth and reform. Washington, DC: Inter-American Development Bank, 2000.

WOOD, C. H.; CARAVALHO, J. A. M. de.; HORTA, C. J. G. The color of child mortality in Brazil, 1950-2000. Latin American Research Review, Pittsburgh, v. 45, 2010 .

WRIGHT, W. R. Café con Leche: a brief look at race relations in twentieth century, Venezuela. Maryland Historian, Maryland, 1970.

WRIGHT, W. R. Elitist Attitudes toward Race in Twentieth-Century Venezuela. In: TOPLIN, R. B. (Ed.). Slavery and race relations in Spanish America. Westport, CT: Greenwood Press, 1974.

WRIGHT, W. R. Race, nationality, and immigration in Venezuelan thought, 18901937. Canadian Review of Studies in Nationalism, Charlottetown, v. 6, 1979.

ZONINSEIN, J. The economic case for combating racial and ethnic exclusion in Latin America and the Caribbean Countries. In: BUVINIC, M.; MAZZA, J.; DEUTSCH, R. (Ed.). Towards a shared vision of development. Washington, DC: InterAmerican Development Bank, 2001.

\section{Teses e outros documentos}

ADAMO, S. C. The broken promise: Race, health, and justice in Rio de Janeiro, 18901940. 1983. Tese (Doutorado) - University of New Mexico, Albuquerque, 1983.

AGUIRRE, M. A. I. Los grupos étnicos en los censos de Guatemala. In: TODOS CONTAMOS: LOS GRUPOS ÉTNICOS EN LOS CENSOS, I ENCUENTRO INTERNACIONAL, 2000, Cartagena de Indias. Anais... Bogotá: Departamento Administrativo Nacional de Estadística et al., nov. 2000.

ALLEN, D. La experiencia de Costa Rica. In: TODOS CONTAMOS: LOS GRUPOS ÉTNICOS EN LOS CENSOS, I ENCUENTRO INTERNACIONAL, 2000, Cartagena de Indias. Anais... Bogotá: Departamento Administrativo Nacional de Estadística et al., nov. 2000. 
ARDITO VEGA, W. Las ordenanzas contra la discriminación. (Working Paper 13). Pontificia Universidad Católica del Perú, Lima, 2009. Disponível em: <http://goo.gl/ fZJpDU>.

ÁVILES BÓSQUEZ, D. Los grupos étnicos en los censos: experiencia de Panamá. In: TODOS CONTAMOS: LOS GRUPOS ÉTNICOS EN LOS CENSOS, I ENCUENTRO INTERNACIONAL, 2000, Cartagena de Indias. Anais... Bogotá: Departamento Administrativo Nacional de Estadística et al., nov. 2000.

BLETZ, M. E. Whiteness of a Darker Color: Narratives of immigration and acculturation in Brazil and Argentina, 1890-1930. 2003. Thesis (Doctoral) Graduate School of Arts and Science, New York University, New York, 2003.

BODNAR, Y. Colombia: apuntes sobre la diversidad cultural y la información sociodemográfica disponible en los pueblos indígenas. In: PUEBLOS INDÍGENAS Y AFRODESCENDIENTES DE AMÉRICA LATINA Y EL CARIBE: RELEVANCIA Y PERTINENCIA DE LA INFORMACIÓN SOCIODEMOGRÁFICA PARA POLÍTICAS Y PROGRAMAS. 2005. Santiago de Chile. Anais eletrônicos... Santiago de Chile: United Nations Economic Commission for Spanish America and the Caribbean, abr. 2005, p. 14. Disponível em: <http://goo.gl/Er5nvJ>.

BRAGA, F. L. Discriminação no mercado de trabalho: Diferenças racias e por sexo no ano de 2003. 2005. Dissertação (Mestrado em Economia) - Universidade Católica de Brasília, Brasília, DF, 2005.

CARDOSO, C. B. Efeitos da politíca de cotas na Universidade de Brasília: uma análise do rendimento e da evasão. 2008. Dissertação (Mestrado em Educação) - Faculdade de Educação, Universidade de Brasília, DF, 2008.

CESAR, R. L. C. Acesso à justiça para minorias raciais no Brasil: é a ação afirmativa o melhor caminho? Riscos e acertos no caso da UERJ. 2003. Tese (Doutorado em Direito) - Faculdade de Direito, Universidade do Estado do Rio de Janeiro, Rio de Janeiro, 2003.

CHIARELLO, R. A. P. Preconceitos e discriminações racias: um olhar de professoras sobre seus(suas) alunos(as) negros(as). 2003. 208 f. Dissertação (Mestrado em Ciências Humanas) - Universidade Federal de São Carlos, São Carlos, 2003. 
DAVIS, D. J. The mechanism of forging a national consciousness: a comparative approach to modern Brazil and Cuba, 1930-1964. 1992. Thesis (Doctoral) - Tulane University, New Orleans, 1992.

DE CERRENO, A. L. C.; PYLE, C. A. Educational Reform in Latin America P7. (Working Paper). New York: Council on Foreign Relations, 1996. Disponível em: $<$ http://goo.gl/SYH88U>.

FORD, C. (Kaya). The Impact of Socioeconomic Quotas on Student Retention: The Case of a Brazilian University. 2011. Tese (Doutorado) - Capella University, Minneapolis, 2011.

GIRALDO, F.; ECHEVERRY, H. F. R. Cambios en el mercado de trabajo de Cali (Colombia), reestructuración económica y social del empleo de la población negra en la década del 90: un análisis de segregación socio-racial a partir de las transformaciones más recientes del mercado de trabajo. In: CONGRESO LATINOAMERICANO DE SOCIOLOGÍA DEL TRABAJO, 3. 2000, Buenos Aires. Resumos... Buenos Aires: Asociación Latinoamericana de Estudios del Trabajo, 2000. Disponível em: <http://goo.gl/XVK0rv>.

GUEVARA, G. R. Founding discourse of cuban nationalism: la patria, blanqueamiento and la raza de color. 2000. Thesis (Doctoral) - University of California, San Diego, 2000 .

HOSTEN, A. Tornar-se negro \& thinking beautiful. (Independent Study Project). Claremont McKenna College, Claremont, 2007. Disponível em: <http://goo.gl/ jYGbwz>.

KAMIENSKA-HODGE, K.; LAJZER, J. The Need for a Narrow-Focused InterAmerican Convention against Racial Discrimination. (Position Paper 1). Human Rights Clinic, University of Texas School of Law, Austin, maio 2009. Disponível em: <http://goo.gl/oAcS0n>.

LEÓN, M.; HOLGUÍN, J. La acción afirmativa en la Universidad de los Andes: el caso del programa "Oportunidades para talentos nacionales". Revista de Estudios Sociales, Bogotá, DC, v. 19, dez. 2004. Disponível em: <http://goo.gl/1FGfgM>.

LESSER, J. Negotiating national identity: middle eastern and asian immigrants and the struggle for ethnicity in Brazil. (Working Paper 8). Center for Comparative Immigration Studies Working Papers, University of California, San Diego, abr. 2000. 
LESSER, J. Negotiating national identity: immigrants, minorities, and the struggle for ethnicity in Brazil. Durham: Duke University Press Books, 1999.

MARINHO, C. M. R. O racismo no Brasil: uma análise do desenvolvimento histórico do tema e da eficácia da lei como instrumento de combate à discriminação racial. Trabalho de conclusão de curso (Especialização) - Universidade Federal de Santa Catarina, Florianópolis, 1999.

NASCIMENTO, A. do. Movimentos sociais, educação e cidadania: um estudo sobre os cursos pré-vestibulares populares. Dissertação (Mestrado em Educação) Universidade do Estado do Rio de Janeiro, Rio de Janeiro, 1999.

NOBLES, M. Responding with good sense: the politics of race and censuses in contemporary Brazil. 1995. Tese (Doutorado em Ciência Política) - Yale University, New Haven, 1995.

NUNES, E. C. Discriminação da criança negra no processo de adoção. 2008. Trabalho de conclusão de curso (Especialização) - Centro de Ensino Unificado de Brasília, Brasília, DF, 2008.

ORGANIZATION OF AMERICAN STATES. Brief Summary of the Status of the Negotiations of the Working Group Organized to Elaborate a Draft of an Inter-American Convention against Racism and All Forms of Discrimination and Intolerance. International Law Department, Washington, DC, 28 maio 2009. Disponível em: <http://goo.gl/vViDZQ>.

POLITICAL feasibility assessment: country potential for new research on race in Latin America. In: TODOS CONTAMOS: LOS GRUPOS ÉTNICOS EN LOS CENSOS, I ENCUENTRO INTERNACIONAL, 2000, Cartagena de Indias. Anais... Bogotá: Departamento Administrativo Nacional de Estadística et al., nov. 2000.

QUEST for inclusion: realizing Afro-Latin potential. (Position Paper 1). Washington, DC: Organization of Africans in the Americas, 2000.

RACUSEN, S. A mulatto cannot be prejudiced: the legal construction of racial discrimination in contemporary Brazil. Thesis (Doctoral) - Dept. of Political Science, Massachusetts Institute of Technology, Cambridge, MA, 2002. 
RODAS NÚÑEZ, I. Identidades y la construcción de la categoria oficial "ladino" en Guatemala. (Working Paper 29). Centre for Research on Inequality, Human Security and Ethnicity, Oxford, out. 2006. Disponível em: <http://goo.gl/BBdHfL>

SCHKOLINK, S.; DEL POPOLO, F. Los censos y los pueblos indígenas en América Latina: una metodologia regional. In: PUEBLOS INDÍGENAS Y AFRODESCENDIENTES DE AMÉRICA LATINA Y EL CARIBE: RELEVANCIA Y PERTINENCIA DE LA INFORMACIÓN SOCIODEMOGRÁFICA PARA POLÍTICAS Y PROGRAMAS. 2005. Santiago de Chile. Anais eletrônicos... Santiago de Chile: United Nations Economic Commission for Spanish America and the Caribbean, abr. 2005, p. 12. Disponível em: <http://goo.gl/GZw4Nv>.

SILVA, M. J. L. Igualdade e ações afirmativas sociais e raciais no ensino superior: o que se discute no STF? 2009. Trabalho de conclusão de curso (Especialização) - Escola de Formação, Sociedade Brasileira de Direito Público, São Paulo, 2009.

SILVA, S. Negros com renda média no bairro da Pituba. 2007. Dissertação (Mestrado) - Universidade Salvador - Unifacs, Salvador, 2007.

SIMÃO, C. Mulher negra: identidade e exclusão social. 2004. Tese (Mestrado em Psicologia) - Universidade São Marcos, São Paulo, 2004.

\section{Páginas de internet}

BANK OF CANADA. 10 Year Currency Converter. Disponível em: <http://goo.gl/ jX9Ucy>.

COLÔMBIA. Instituto Colombiano de Crédito Educativo y Estudios Técnicos en el Exterior. Bogotá, [20--]. Disponível em: <http://goo.gl/He3dKT>.

CONSULTORÍA PARA LOS DERECHOS HUMANOS Y EL DESPLAZAMIENTO. Desplazamiento forzado y enfoques diferenciales, Doc. 9.

Disponível em: <http://goo.gl/VFnSt9>.

CONSULTORÍA PARA LOS DERECHOS HUMANOS Y EL

DESPLAZAMIENTO. Afrocolombianos desplazados, un drama sin tregua. 22 maio 2008. Disponível em: <http://goo.gl/3AXuT5>.

ESTADOS UNIDOS. Bureau of International Labor Affairs. Labor Rights Report, n. 31, set. 2007. Department of Labor, Peru. Disponível em: <http://goo.gl/xzr2aW>. 
GLOBAL RIGHTS PARTNERS FOR JUSTICE. Latin America: Promoting the Rights of Colombia's Afro-Descendants. [S.1.], [200-]. Disponível em: <http://goo. gl/OghyNC>.

GOMES, J. B. B. Discriminação racial: Um grande desafio para o direito brasileiro. Adami Advogados Associados, Rio de Janeiro. Disponível em: <http://goo.gl/ cYV9Sg>.

GRIECO, E. M. Race and Hispanic Origin of the Foreign-Born Population in the United States: 2007. American Community Survey Reports, jan. 2010. Disponível em: <http://goo.gl/MP2fe6>.

INTERNATIONAL DEVELOPMENT RESEARCH CENTRE. Examples of Cases Studied by the Project (Peru, 1995-2000), [200-]. Disponível em: <http://goo.gl/ UNQf8A>.

INTER-AMERICAN COMMISSION ON HUMAN RIGHTS. Annual Report: Peru. 2000. Disponível em: <http://goo.gl/EK9kMm>.

INTER-AMERICAN COMMISSION ON HUMAN RIGHTS. Release Report on Afro-Descendants in Colombia. 15 maio 2009. Disponível em: <http:/goo.gl/ $\mathrm{EEdNrJ}>$.

INTER-AMERICAN COMMISSION ON HUMAN RIGHTS. Report on the Situation of Human Rights in Brazil. 29 set. 1997. Disponível em: <http://goo.gl/ fghRkE>.

INSTITUTO BRASILEIRO DE ANÁLISES SOCIAIS E ECONÔMICAS. Rompendo o cerceamento da palavra: a voz dos favelados em busca de reconhecimento. Rio de Janeiro, 11 nov. 2007. Disponível em: <http://goo.gl/ TmFOPR>.

IBGE. Síntese de indicadores sociais 2006, estudos \& pesquisas: informação demográfica e socioeconômica, n. 19, 2006. Disponível em: <http://goo.gl/ GaoCST>.

IBGE. Síntese de indicadores sociais 2008, estudos \& pesquisas: informação demográfica e socioeconômica, n. 23, 2008. Disponível em: <http://goo.gl/ YKO3FP>.

IBGE. Síntese de indicadores sociais: uma análise das condições de vida da população brasileira, 2010. Disponível em: <http://goo.gl/AGrCiE>. 
LATIN AMERICAN PUBLIC OPINION PROJECT OF VANDERBILT

UNIVERSITY. Americas Barometer 2010. 2010a. Disponível em: <http://goo.gl/

LE6IDj>.

LATIN AMERICAN PUBLIC OPINION PROJECT OF VANDERBILT

UNIVERSITY. Americas Barometer 2010: Ethnicity Module of the Project on

Ethnicity and Race in Latin America (Perla). 2010b. Disponível em: <http://goo.

gl/7FQw93>.

PROGRAMA NACIONAL DE EMPLEO JUVENIL. Listo proyecto para prohibir discriminación laboral en las ofertas de empleo, Jóvenes a la Obra. 2010. Disponível em: <http://goo.gl/ZFqWnY>.

SMITH, A. E. Who Supports Affirmative Action in Brazil. LAPOP Americas

Barometer Insights, Nashville, n. 49, 2010. Disponível em: <http://goo.gl/k95sQZ>.

SMITH, M. Educational Reform in Latin America: Facing a Crisis. International

Development Research Center Report, 19 fev. 1999. Disponível em: <http://goo.

$\mathrm{gl} / 8 \mathrm{TC} 5 \mathrm{qX}>$.

UNITED NATIONS HIGH COMMISSION FOR HUMAN RIGHTS.

Compilation of Final Observations of the Committee for the Elimination of Racial

Discrimination Regarding the Countries of Latin America and the Caribbean: 1970-

2006. Latin America and the Caribbean Regional Representation, jun. 2006.

Disponível em: <http://goo.gl/B7JiEH>.

UNITED NATIONS HIGH COMMISSION FOR HUMAN RIGHTS. Concluding Observations of the Committee on the Elimination of Racial Discrimination: Colombia. 20 ago. 1999. Disponível em: <http://goo.gl/qCM4Ej>.

U.S. DEPARTMENT OF STATE. 1999 Country Reports on Human Rights Practices, Bureau of Democracy, Human Rights, and Labor. 25 fev. 2000. Disponível em: $<$ http://goo.gl/AifjsT>.

VESTIBULAR UERJ. Dados Socioculturais 2010. Rio de janeiro, 2010. Disponível em: <http://goo.gl/iqb2w4>. 


\section{Apêndice A - Organizações de afrodescendentes na América Latina}

\section{Argentina}

Asociación Civil “África y su Diáspora para la Defensa de los

Derechos Humanos”

asociacionafricaysudiaspora@yahoo.com.ar

www.africaysudiaspora.com.ar

Asociación Civil África Vive

pochalamadrid@yahoo.com.ar

Asociación Civil y Religiosa Ile Ase Osun Dayo

info@doyo.com.ar

www.doyo.com.ar

Asociación Misibamba. Comunidad Afroargentina de BuenosAires

jsuaque@yahoo.com.ar

bakongocandombe@gmail.com 
Casa de la cultura Indo-afroamericana

indoafro@hotmail.com

indoafroamericana@yahoo.com.ar

Sociedad de Socorros Mutuos Unión Caboverdeana

sociedadcaboverdeana@yahoo.com.ar

\section{Bolívia}

Centro Afroboliviano para el Desarrollo Integral y Comunitario (Cadic) jorgemedina_bol@yahoo.com

contactos@cadic.org.bo

www.cadic.org.bo

Fundación de Afrodescendientes Pedro Andaverez Peralta (Fundafro-PAP) fundafro@hotmail.com

Movimiento Cultural Saya Afroboliviano (Mocusabol)

afrobolivia88@yahoo.es

www.afrobolivia.org.bo

\section{Brasil}

Agentes de Pastoral Negros do Brasil

apnsbrasil@yahoo.com.br

www.apnsbrasil.com.br

Articulação de Mulheres Negras

amnb@uol.com.br

http://www.amnb.org.br/site/

Articulação Política de Juventudes Negras

apjnbrasil@yahoo.com.br

www.apjnbrasil.blogspot.com

Associação Brasileira de Pesquisadores(as) Negros(as)

adpn@adpn.org.br

www.adpn.org.br 
Associação Vida Inteira

francgunzo@gmail.com

http://associacaovidainteira.wordpress.com/

Casa da Cultura da Mulher Negra

ccmnegra@uol.com.br

www.casadeculturadamulhernegra.org.br

Centro de Estudos e Pesquisa de Intercambio da Cultura Africana (Centro Cultural Africano)

cca@centroculturalafricano.org

www.centroculturalafricano.org.br

Congresso Nacional de Negras e Negros do Brasil (Conneb)

conneb.org.br

Coordenação das Associações das Comunidades Remanescentes de

Quilombos do Pará

malungupara.org.br

malungu.pa@hotmail.com

Criola

criola@criola.org.br

www.criola.org.br

Educafro

freidavid@gmail.com

www.educafro.org.br

Escola de Educação Percussiva Integral (EEPI)

eepipercussiva@gmail.com

http://www.myspace.com/escolapercussiva

Fala Preta Organização de Mulheres Negras

deisebenedicto45@yahoo.com.br

falapret@uol.com.br 
Forum Estadual de Juventude Negra do Espírito Santo (Fejunes)

Fejunes_es@yahoo.com.br

www.fejunes.blogspot.com

Fundação Baobá (Fund for Racial Equity)

baoba@baoba.org.br

www.baoba.org.br

Geledes Instituto da Mulher Negra

geledes@geledes.org.br

www.geledes.org.br

Ilú Oba De Min - Educação, Cultura e Arte Negra

iluobademin@yahoo.com.br

www.iluobademin.com.brwww.myspace.com/

bandafemininadepercussoliobdemin

Instituto AMMA Psique e Negritude

ammapsi@uol.com.br

Instituto de Assessoria a Projetos e Pesquisas em Educação eEtnia Odoya edevaldoed@gmail.com

edevaldoj@vivax.com.br

Instituto de Mulheres Negras do Amapá

imenamacapa@yahoo.com.br

Instituto Negra do Ceará (Inegra)

inegra.ce@gmail.com

inegrace.wordpress.com

Irmandade dos Quilombolas Afrodescendentes do Quilombo Santacruz

(Aquiloafros)

aquiloafros@hotmail.com

vandelip@hotmail.com 
Koinonia Presença Ecumênica e Serviços

koinonia@koinonia.org.br

www.koinonia.org.br

Maria Mulher-Organização de Mulheres Negras

mariamulher@mariamulher.org.br

www.mariamulher.org.br

Mundo Negro

www.mundonegro.com.br

Núcleo de Resgate e Preservação da Cultura Afro-Brasileira-Omi-dudu Artes bartolomeudc@yahoo.com.br;

joseliaomidudu@yahoo.com.br

www.nucleoomidudu.org.br

Povo Kalunga

coordenacao@povokalunga.org.br

Rede Afro-brasileira Sociocultural

redeafro@hotmail.com

http://redeafro.ning.com

Rede Mulheres Negras do Paraná

redemulheresnegras@yahoo.com.br

www.redemulheresnegraspr.org.br

Unegro

http://www.unegro.org.br/site/

Ylë Axé Opô Omim I (Associação Casa Caminho da Alegria)

yleaxeopoomin@hotmail.com

Casa Caminho da Alegria

casacaminhoalegria@yahoo.com.br

casacaminhoalegria.blogspot.com 


\section{Chile}

Organización Cultural y Social de Afrodescendientes Chilenos Lumbanga organizacionlumbanga@yahoo.es

afrochileno@yahoo.es

www.afrochileno.blogspot.com

Organización No Gubernamental Oro Negro de Afrodescendientes Chilenos martavictoriasalgado619@hotmail.com

afrochile@gmail.com

www.ong-oronegro.blogspot.com

\section{Colômbia}

Asociación de Alcaldes de Municipios con Población Afrodescendiente

(Amunafro)

contacto@amunafro.com

www.amunafro.com

Asociación Colombiana de Peluqueros y Peinadores Afrodescendientes asocolppa@gmail.com

www.asocolppa.blogspot.com

Asociación para el Desarrollo Integral de las Comunidades Afrocolombianas

(Kumananá)

kumana.pcn@renacientes.net

www.renacientes.org

Asociación de Ecoturismo del Bajo Anchicayá Los Tucán

hvallecillac@gmail.com

herlmer1972@hotmail.es

Asociación para el Fomento de la Integración de las Negritudes (AFIN) afin85@hotmail.com

Asociación para las Investigaciones Culturales del Choco (Asinch)

asinch.choco@gmail.com

www.asinch.blogspot.com 
Asociación Mutual para el Desarrollo de la Afrocolombianidad y el Cooperativismo

afromutual@gmail.com

www.fundartecp.com

Asociación Nacional de Afrocolombianos Desplazados (Afrodes)

afrodescolombia@gmail.com

www.afrodes.org

Centro de Documentación Cultural Afrocolombianas

bikookib@hotmail.com

Cimarron

cimarronnacional@movimientocimarron.org

http://www.movimientocimarron.org/

Consejo Comunitario de la Comunidad Negra del Río Cajambre cccajambre@yahoo.com

Consejo Comunitario de la Comunidad Negra del Río Naya consejocomunitariorionaya@yahoo.es

Consejo Comunitario Cuenca del Río Naya

luzdalmi@yahoo.com.ar

Consejo Comunitario de la Cuenca del Río Mayorquín

Mayorevan@hotmail.com

Corporación Cultural Afrocolombiana Sankofa

www.sankofadanzaafro.wordpress.com

sankofadanzafro@hotmail.com

Corporación para el Desarrollo Social y Empresarial de los Pueblos

Afrocolombianos (Ecodesarrollo)

info@ecodesarrollo.org.co

www.ecodesarrollo.org.co 
Corporación para el Fomento de la Investigación Etnoeducativa, Sociocultural, Económica y Ambiental Afrocolombiana Ancestros (Corporación Ancestros) corpoancestro@yahoo.com www.renacientes.org

Corporación Identidad Cultural (Corpidencu) corpidencu@gmail.com www.corpidencu.net

Ecotambor ecotambor@yahoo.com

Federación Afroamérica XXI rosacv2003@yahoo.com www.afroamerica21.org

Fundación Afroamericana para la Educación Cultura y Desarrollo (Fundafro) Fundafro001@yahoo.com

Fundación para la Formación de Líderes Afrocolombianos (Afrolider) fundafrolider@etb.net.com

Asociación de Afrocolombian@s en Itagui

Socorro3384@hotmail.com

Fundación Afroguajira (Funagua)

yohanis_mejia@hotmail.com

fundación-afroguajira@hotmail.com

Fundación Arte y Cultura del Pacífico (Fundartecp)

fundartecp@yahoo.es

www.fundartecp.com

Fundación Assim Bonanga

gmakanaky@hotmail.com 
Fundación Instituto para el Desarrollo Cultural y Educativo de las Etnias (Funidescudet)

funidescudet@hotmail.com

funidescudet.jimdo.com

Fundación Valores de Nuestra Etnia

cambindo75@hotmail.com

Kilombo Organizativo para la Reivindicación Afrodescendiente (KORA) griots_0000000001@hotmail.com

Organización Social de Comunidades Negras Ángela Davis

organizacionangeladavis@gmail.com

Malawi@yahoo.com

www.organizacionsocialangeladavis.com

Processo de Comunidades Negras (PCN)

http://www.renacientes.org/

Red Nacional de Mujeres Afrocolombianas Kambirí

auradalia@yahoo.com

redmujerafro@hotmail.com

redmujerafro.tripod.com

Unidad Fraternal Palenque (UFP)

ufplibre@hotmail.com

\section{Costa Rica}

Asociación para el Desarrollo de la Mujer Negra Costarricense

mujerdp@ice.co.cr

http://mujeresafrocostarricenses.blogspot.com

Asociación Proyecto Caribe

asociación.proyectocaribe@hotmail.com

procarib@ice.co.cr

www.proyectocaribe.org 
Red de Mujeres Afro Latinoamericanas y Afro Caribeñas www.movemientos.org/mujerafro

Cuba

AfroCuba

director@afrocuba.org

www.afrocuba.org

Cofradía de la Negritud (Coneg)

afrocubaweb.com/coneg/coneg.htm

Comisión de Lucha Contra el Racismo y la Discriminación, de la Uneac (Union of Artists \& Writers)

www.afrocubaweb.com/uneaccomissionracism.htm

\section{Equador}

Acción y Desarrollo Comunitario (Acdecom)

Adecom.ecuador@yahoo.es

adecom@uio.satnet.net

acdecom.wordpress.com/contactos

Asociación Presencia Negra Ecuatoriana (Anpne)

afroec98anpne@hotmail.com

Asociación Social y Cultural para la Integración de la Raza Negra del

Ecuador (Ascrine)

ascirne@hotmail.com

www.ascirneafroecuatoriana.org

Centro Internacional de Esmeraldas para la Diversidad Cultural

Afroindoamericana y el Desarrollo Humano

mindapanibal@yahoo.es

Centro Cultural Afroecuatoriano

cca@centroafroecuatoriano.com

www.centroafroecuatoriano.com 
Confederación Nacional Cultural Africanos en la Diáspora para la Defensa y Desarrollo Integral del Ser Humano y su Entorno (Concadishe) concadishe@yahoo.com www.concadishe.org

Coordinadora Nacional de Mujeres Negras (Conamune) mujeresnegras@coopi.org conamune.org

Federación de Comunidades e Organizaciones Negras de Imbabura y Carchi (Feconic) info@feconic.org http://www.feconic.org/

Federación de Organizaciones y Grupos Negros del Guayas vidal38leones@hotmail.com

Fundación Cimarrón Siglo XXI Ecuador cimarronxxi@gmail.com ibsen8@gmail.com

Fundación Cultural y Artesanal Afroecuatoriana Ochún afromosquera@yahoo.es

Fundación de Desarrollo Social y Cultural Afroecuatoriana Azúcar info@azucarafroe.com www.azucarafroe.com

Fundación de Integración, Desarrollo y Acción Social (Ideas) funideas05@hotmail.com

\section{Guatemala}

Centro de Investigaciòn Afrocaribe Wadeimalu Garifuna wadimalu.centro@gmail.com 


\section{Honduras}

Asociación de Micro, Pequeños y Medianos Empresarios Afrohondureños (Camafroh) cedecoxxi@yahoo.com rguevara@hondumail.net

Comité de Emergencia Garífuna de Honduras

Afro_cagah@yahoo.com www.cegah.org

Ecosalud

ecosalud98@yahoo.com ecosalud.org

Fundación Luagu Hatuadi Wduheñu "Por la Salud de Nuestros Pueblos" fhatuadiw@yahoo.es www.atuadi.org

Organización Afrohondureña de la Juventud (Oafrohju) oafrohju@hotmail.com

Organización de Desarrollo Étnico Comunitario (Odeco) odeco@caribe.hn clavarez@caribe.hn www.odeco.org Organización Fraternal Negra Hondureña (Ofraneh) ofraneh@yahoo.com www.ofraneh.org Organización Negra Centroamericana (Oneca) odeco@caribe.hn clavares@caribe.hn

Fundación Hondureña para la Defensa de la Cultura Garifunas y Centro de Cultura Garinagu de Honduras (Cencuglar) garinagu@cablecolor.hn 


\section{México}

África A. C.

I_reyes_larrea@hotmail.com

colectivo_africa@hotmail.com

colectivoafrica.blogspot.com

Centro de Derechos Humanos, Ciudadanos y Autonómicos(Cedehca)

información@cedehcanicaragua.com

www.cedehcanicaragua.com

Colectivo Regional para la Defensa de los Pueblos Indígenas yNegros de Oaxaca México (Colectivo Pinotepa)

colectivopinotepa@gmail.com

www.colectivopinotepa.blogspot.com

México Negro AC

gynmexneg@hotmail.com

mexiconegroac.blogspot.com

\section{Nicarágua}

Nicaribbean Black People Association (NBPA)

duhindo@yahoo.com

bush-black@hotmail.com

Red de Mujeres Afrolatinoamericanas, Afrocaribeñas y de laDiáspora mafroni@cablenet.com.ni

www.mujeresafro.org

\section{Panamá}

Asociación de Puertos Obaldieños Unidos

apou@cwpanama.net

apou@cableonda.net

Asociación Respuesta Afropanameña

ellen_greaves99@yahoo.com 
Centro de Estudios Afropanameños (Cedeap)

gmaloneyf@hotmail.com

nerebet_470@hotmail.com

Centro de la Mujer Panameña (Cemp)

cemp76@hotmail.com

Comisión de la Etnia Negra de Colón

cgarnesafro@msn.com

selviamillerpalmaresselviam@panama.net

la_negra@hotmail.com

Consejo Nacional de Etnias Negras (Conen)

http://conenpanama.com

Coordinadora Nacional de las Organizaciones Negras Panameñas (Conegpa)

eunice108@hotmail.com

diadelaetnia.homestead.com/coordinadora.html

Fundación Bayano

fundaba@cwpanama.net

www.fundacionbayano.org/panama

Fundación para la Gestión del Arte Afrodescendiente (FUGAA)

proyectofuga@walla.com

Fundación de Mujeres Afrodescendientes Trabajando para la Comunidad

(Fumuafro)

horowe@pancanal.com

hortensiarowe@yahoo.com

Grupo Congo de Panamá “Tradiciones de mi raza”

pcongodepanama@gmail.com

Sociedad de Amigos del Museo Afroantillano de Panamá (Samaap)

info@samaap.org

www.samaap.org 


\section{Paraguai}

Asociación Afroparaguaya Kamba Cua (AAPKC)

morenada01@hotmail.com

Comisión Cultural Afro-descendiente Kamba Kokue Virgen del Rosario susiarce1@gmail.com

\section{Peru}

Asociación Afroperuana Comprometida con el Desarrollo Sostenible (Cumana)

cumanapiura@gmail.com

Grupo Cultural Afroperuano Las Sabu de Isamar

lasabuisamar@hotmail.com

Asociación Civil Raíces Afroperuana

vickyzega@hotmail.com

raices_afroperuana@hotmail.com

Asociación Cultural de Promoción y Desarrollo “Todas las Sangres”

todaslassangres@hotmail.com

agztodaslassangres@yahoo.es

www.cimarrones-peru.org/todaslas.htm

Asociación Negra de Defensa y Desarrollo de la Mujer y Juventud Chinchana-Margarita

margaritachinchaafro@hotmail.com

www.cimarrones-peru.org/marga.htm

Asociación Negra de Defensa y Promoción de los Derechos Humanos (Asondeh)

asondeh@asondeh.com

www.asondeh.com

Centro de Desarrollo Étnico (Cedet)

cedetdir@ec-rec.com

www.cedet.net 
Centro de Desarrollo de la Mujer Negra Peruana (Cedemunep) cedemunep@hotmail.com www.cedemunep.org

Centro para el Desarrollo Urbano y Rural (Cepdur)

MPRO_cepdur@speedy.com.pe

Cimarrones

www.cimarrones-peru.org

Centro de Estudios y Promoción Afroperuanos (Lundu)

lundu@lundu.org.pe

www.lundu.org.pe

Makungu para el Desarrollo

perumakungu@gmail.com

perumakungu.blogspot.com

Organización Afroperuana para el Desarrollo Étnico de Cañete (Ña Catita) afrocatitasanluis@hotmail.com

Songorocosongo

afrosongo@hotmail.com

Red Nacional de Jóvenes Afroperuanos (Ashanti)

ashanti-reddejovenes@hotmail.com

ashanti-peru.blogspot.com

\section{República Dominicana}

Centro Cultural Dominico-Haitiano (CCDH)

Ccdhjulio1982@gmail.com

http://www.ccdh.org.do

Fundación Étnica Integral (La Fei)

ong.fei@gmail.com 
Movimiento de Mujeres Dominico-Haitiana (Mudha)

mudhaong@hotmail.com

\section{Uruguai}

Artesanías Étnicas (Nzinga)

intiartesana@gmail.com

http://ancestralesafro.blogspot.com

http://afroarte.blogspot.com

http://nzinga.winnernet.net

Asociación Afro Iberoamericana (Afrib)

afroaii@gmail.com

cgalloso@adinet.com.uy

Asociación Civil Africanía

toliverach@hotmail.com

www.bantuuruguay.com

Centro Cultural por la Paz y la Integración (Cecupi)

cecupi.org@hotmail.com

www.cecupi.blogspot.com

Escuela de Candombre de Cerro Largo

Candombe101@adinet.com.uy

Federación IFA del Uruguay (Instituciones Federadas Afroumbandistas)

Atabaque

ifadeluruguay@hotmail.com

www.atabaque.com.uy

Grupo Cultural Afrogama

afrogama@hotmail.com

www.afrogama.blogspot.com

Mujeres Jóvenes Afrodescendientes (Mizangas)

reuniondemizangas@gmail.com 
Organizaciones Mundo Afro

mundoafro@gmail.com

www.mundoafro.org

Organización Social Salvador por un Movimiento Afrouruguayo

http://organizacionsocialsalvador.blogspot.com/

Uafro

uafro@adinet.com.uy

aliciaesqui@gmail.com

Venezuela

Fundación Afro-América

www.fundacionafroamerica.com 


\section{Apêndice B - Tipologia das medidas contra a discriminação na América Latina}

Nation

Argentina

Bolivia

Brazil

Chile

Colombia

Costa Rica

Cuba

Dominican Republic

Ecuador

El Salvador

Guatemala

Honduras

Mexico

Nicaragua

Panama

Paraguay

Peru

Uruguay

Venezuela

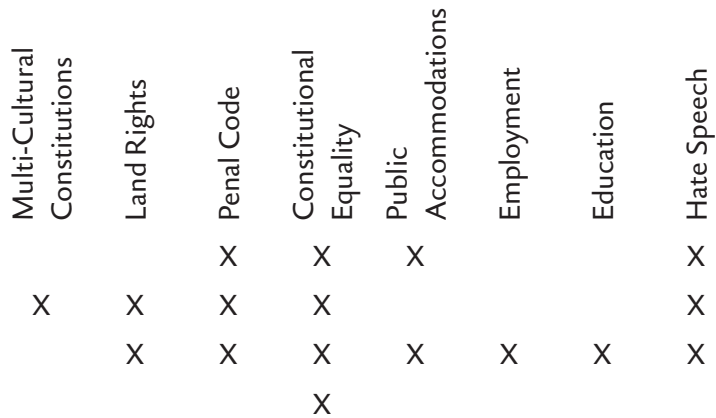
$x \quad x \quad x \quad x \quad x \quad x$ $\begin{array}{llllll}x & x & x & x & x & x \\ x & x & & & & x\end{array}$

\begin{tabular}{|c|c|c|c|c|c|c|c|}
\hline & & & $X$ & & & & \\
\hline \multirow[t]{2}{*}{$X$} & $x$ & $x$ & $x$ & & & $X$ & $x$ \\
\hline & & $x$ & & & & & \\
\hline$x$ & $x$ & $X$ & $X$ & & & $X$ & $x$ \\
\hline$X$ & $X$ & & $X$ & & & & \\
\hline$X$ & & $X$ & $X$ & $X$ & $X$ & & $X$ \\
\hline \multirow[t]{2}{*}{$X$} & $x$ & & $x$ & & & & \\
\hline & & $X$ & $X$ & $X$ & $X$ & & \\
\hline \multirow[t]{3}{*}{$X$} & & & $x$ & & & & \\
\hline & & $X$ & $X$ & $X$ & $X$ & $X$ & $x$ \\
\hline & & $X$ & & & & & $x$ \\
\hline$X$ & $X$ & $x$ & & & & $X$ & \\
\hline
\end{tabular}




\footnotetext{
7 ste livro foi produzido em formato $180 \times 240 \mathrm{~mm}$ e utiliza as tipografias

Riona Sans e DTL Haarlemmer, com miolo impresso na Edufba, em papel Alta Alvura $75 \mathrm{~g} / \mathrm{m}^{2}$ e capa em Cartão Supremo $300 \mathrm{~g} / \mathrm{m}^{2}$, impressa na Bigraf.

Tiragem: 400 exemplares.
} 